UNIVERSIDADE DE SÃO PAULO

FACULDADE DE FILOSOFIA, LETRAS E CIÊNCIAS HUMANAS

DEPARTAMENTO DE FILOSOFIA

PÓS-GRADUAÇÃO EM FILOSOFIA

A recusa do transcendental: um estudo sobre a filosofia crítica de Foucault

Carolina de Souza Noto 


\section{A recusa do transcendental: um estudo sobre a filosofia crítica de Foucault}

Carolina de Souza Noto

Tese apresentada ao Programa de Pós-Graduação em Filosofia do Departamento de Filosofia da Faculdade de Filosofia, Letras e Ciências Humanas da Universidade de São Paulo, para a obtenção do título de Doutor em Filosofia sob a orientação do Prof. Dr. Carlos Alberto Ribeiro de Moura.

São Paulo

2014 
Para Helena, que nasceu junto com essa tese. 
Ao companheiro Pedro, agradeço pela revisão cuidadosa desse trabalho e sobretudo pela amizade e pelo amor.

Agradeço o carinho dos meus pais, Iara e Julio, e dos meus irmãos, Juliana, Andrea, Felipe e Cristiano.

Agradeço o estímulo dos amigos Gabriela, Guilherme, Leandro, Sylvia, Daniel e Joana.

Ao Carlos Alberto agradeço pela leitura atenta do meu trabalho e pela orientação, sempre tão precisa, e bem humorada.

Agradeço a Márcio Suzuki e a Pedro Paulo Pimenta pela participação na banca de qualificação da tese.

A Débora Morato agradeço pela ajuda “internacional".

Agradeço a Frédéric Worms e Francis Wolff pela acolhida em Paris durante o estágio "sanduíche”. Agradeço o apoio institucional e burocrático da secretaria do Departamento de Filosofia. Agradeço à Fapesp, pelo apoio financeiro. 


\title{
RESUMO
}

NOTO, C. A recusa do transcendental: um estudo sobre a filosofia crítica de Foucault. 2014. 179 f. Tese (Doutorado) - Faculdade de Filosofia, Letras e Ciências Humanas. Departamento de Filosofia, Universidade de São Paulo, São Paulo, 2014.

A hipótese desse trabalho é a de que é possível encontrar uma unidade sistemática no pensamento filosófico de Michel Foucault. Desde os escritos arqueológicos da década de 60 até as últimas considerações, arqueológicas e genealógicas, sobre a ética e a subjetividade, o que se vê é um tipo de reflexão filosófica que concilia uma discussão sobre a linguagem e uma sobre o homem. Tratase, então, de mostrar como, metodologicamente, Foucault constrói tal reflexão.

Palavras-chave: Arqueologia, genealogia, homem, linguagem.

\begin{abstract}
NOTO, C. The refusal of the transcendental: a study of the critical philosophy of Foucault. 2014. 179 f. Thesis (Doctoral) - Faculdade de Filosofia, Letras e Ciências Humanas. Departamento de Filosofia, Universidade de São Paulo, São Paulo, 2014.

The hypothesis of this work is that it is possible to find a systematic unity in Michel Foucault's philosophical thought. From his archaeological writings produced in the 1960's to the last archaeological and genealogical considerations on ethics and subjectivity, one notices a kind of philosophical reflection that conciliates a discussion about language and a discussion about man. This research shows how Foucault methodologically constructs that reflection.
\end{abstract}

Keyword: Archaeology, genealogy, man, language. 


\section{ÍNDICE}

Introdução p. 8

\section{PRIMEIRA PARTE \\ KANT E A ARQUEOLOGIA}

Capítulo 1. O problema do duplo empírico-transcendental nas analíticas da finitude

(O campo epistemológico das ciências humanas; O homem; A confusão entre empírico e transcendental nas ciências empíricas; A questão da finitude na França dos anos 50: o Kant de Vuillemin; A finitude em Foucault; Uma ontologia da finitude: um retorno às metafísicas pré-kantianas)

Capítulo 2. Kant: antropologia pragmática e a noção de uso p. 37

(Empirico e transcendental na Antropologia de um ponto de vista pragmático; A relação entre natureza e liberdade: antinomia da razão e uso; O papel vivificador das representações ilusórias)

Capítulo 3. Foucault: a arqueologia enquanto análise dos usos da linguagem

(O projeto anti-humanista de A arqueologia do saber; $A$ suspensão do transcendental; $O$ enunciado como práticas discursivas: o uso da linguagem e o caráter pragmático do discurso; Antropologia pragmática e arqueologia: das condições de validade às condições de existência; O problema da liberdade na passagem da arqueologia à genealogia)

\section{SEGUNDA PARTE \\ NIETZSCHE E A GENEALOGIA}

Capítulo 4. Dois paradigmas da vontade de saber: Aristóteles e Nietzsche p. 95

(Foucault, Nietzsche e Heidegger; Aristóteles e Nietzsche: dois paradigmas da vontade de saber; A vontade de saber em Aristóteles: todos os homens por natureza desejam conhecer; A vontade de saber em Nietzsche: o conhecimento como invenção; A exterioridade do conhecimento em Nietzsche; Conhecimento trágico $x$ conhecimento teórico; Conhecimento corporal x conhecimento ascético; A verdade como interpretação em Nietzsche; Foucault leitor de Kant e Nietzsche: o uso interessado das representações)

Capítulo 5. Quem fala? A vontade de saber em Foucault p. 134

(A exterioridade do conhecimento: a história da nossa vontade de verdade entre Nietzsche, Dumézil e a psicologia histórica; A Grécia clássica e a nova concepção de justiça: a verdade como constatação; A genealogia do sujeito puro de conhecimento e do valor apofântico da verdade; A verdade como interpretação: o discurso filosófico como ficção)

Conclusão: A filosofia crítica de Foucault e a relação entre homem e linguagem p. 159

Bibliografia p. 175 
odeio tudo aquilo que somente me instrui sem aumentar ou estimular diretamente a minha atividade. (Carta de Goethe a Schiller, 19/12/1798, apud Nietzche, II Considerações intempestivas, p.67)

De que valeria a obstinação do saber se ele assegurasse apenas a aquisição dos conhecimentos e não, de certa maneira, e tanto quanto possivel, o descaminho daquele que conhece? (Foucault, $O$ uso dos prazeres, p. 13) 


\section{INTRODUÇÃO}

Em um de seus livros mais importantes, As palavras e as coisas (1966), Foucault defende a tese de que na modernidade (isto é, a partir do final do século XVIII) não está mais em questão aos saberes em geral descrever como se dá a relação entre uma representação e outra, entre uma ideia e outra, mas em se perguntar como a representação em si é possível. Para o filósofo, principalmente no campo da reflexão filosófica, tornam-se centrais as questões relativas às condições de possibilidades a priori da experiência, ao transcendental, ou seja, àquilo que está aquém ou além das representações, mas que ao mesmo tempo é aquilo mesmo que as possibilita ${ }^{1}$.

$\mathrm{Na}$ filosofia, Kant é o marco dessa mudança de episteme com a separação, por exemplo, do "Eu penso" e do "Eu sou". O "Eu penso" ainda diria respeito ao cogito cartesiano povoado de representações; o "Eu sou”, por outro lado, seria o objeto da investigação crítica que se pergunta "o que sou eu que sou capaz de ter representações e de pensar". Para Foucault, contudo, o sujeito transcendental kantiano ainda não é exatamente aquilo que constitui o que ele chama de homem, que é o objeto específico das ciências humanas e de certo tipo de reflexão filosófica chamada, pelo autor de As palavras e as coisas, de analítica da finitude. O sujeito transcendental é um sujeito puro, lógico. O homem, entretanto, será uma figura mista, um misto ontológico, e não somente lógico, de transcendental e de empírico; uma figura que tentará ser representada naquilo mesmo que escapa à representação, na sua finitude.

O caráter duplo do homem irá comprometer todas as reflexões que procuraram compreender o estatuto ontológico de sua condição contraditória, condição esta que é a de um ser, a um só tempo, constituinte e constituído, determinante e determinado. Segundo Foucault, todas estas reflexões caem naquilo que o filósofo chama de "ilusão antropológica", que não deixa de ser uma espécie de repetição da "ilusão transcendental” denunciada por Kant. Além disso, é em função de uma torção no sentido da ilusão transcendental que boa parte da reflexão filosófica, depois de Kant, recai no mesmo erro denunciado pelo filósofo alemão e volta a adormecer num sono, não mais o sono dogmático, mas o sono antropológico.

De acordo com Foucault, a ilusão transcendental analisada por Kant na Crítica da Razão Pura foi questionada pelas analíticas da finitude, num nível ainda mais radical e fundamental. Assim, se, para Kant, a ilusão transcendental consistia numa transgressão natural da razão para além dos limites da experiência possível, para as analíticas da finitude interessava descobrir o ser mesmo dessa razão ou do homem, que naturalmente vai além de seus próprios limites. Para Foucault, a

${ }^{1}$ Cf. Foucault, As palavras e as coisas, p. 225. 
passagem de Kant às analíticas da finitude caracterizar-se-ia, portanto, pela passagem de uma reflexão sobre as condições de possibilidade formais do conhecimento para uma reflexão acerca da natureza da natureza humana.

Em As palavras e as coisas, Foucault nos propõe, então, a seguinte tese: o aparecimento do homem, na modernidade, é tributário da descoberta kantiana do transcendental, assim como da torção que se realizou na questão da ilusão transcendental. Além disso, esta concepção de homem que surge no limiar da Idade Clássica para a Idade Moderna é correlata ao desaparecimento de uma reflexão sobre a representação e sobre o Discurso. Mas, se o nascimento do homem marca a passagem da episteme clássica à episteme moderna, Foucault percebe também que, em sua época, algo está em vias de acontecer: uma nova ruptura de episteme. Esse é, pois, o sentido mais forte da afirmação de que o homem está condenado à morte. O que nota Foucault é que o homem, que "não é o mais velho problema nem o mais constante que se tenha colocado ao saber humano"2, está começando a deixar de ser a questão central do saber; nota, ademais, que os novos saberes que estão dispostos a contornar a problemática do homem o fazem por meio de uma reflexão sobre a linguagem. É o que observa Foucault desde Nietzsche a Lévi-Strauss, passando por Mallarmé, Freud, Blanchot e Bataille. É daí, então, que vem um importante complemento à tese anunciada acima: se o homem nasce com o desaparecimento do Discurso, a morte do homem é acompanhada por um retorno da linguagem. Um retorno que, na França, se dá a partir de meados do século XX principalmente com o estruturalismo e com as análises literárias de Blanchot e Bataille, e que vem para contornar os problemas colocados pelas analíticas da finitude, encarnadas basicamente pelas discussões ditas humanistas e antropológicas da fenomenologia e do existencialismo.

Dividir a tese foucaultiana de As palavras e as coisas em dois momentos é importante, pois isto aponta para a diferença entre o diagnóstico e o prognóstico realizados pelo filósofo. A primeira observação de Foucault é a de que o homem é um problema que nasceu há dois séculos: diagnóstico. Depois, ele nota também que este problema vem sendo substituído pelo problema da linguagem: prognóstico. Por se tratar do futuro, o prognóstico de Foucault não parece ser definitivo. Em nenhum momento o filósofo afirma que a única possibilidade para uma nova filosofia, uma nova filosofia capaz de superar as analíticas da finitude, seja o retorno da linguagem e o abandono da questão do homem. É certo que ele observa que, na sua atualidade, o ser do homem vem sendo substituído pela problemática do ser da linguagem; é certo também que ele afirma que "jamais, na cultura ocidental, o ser do homem e o ser da linguagem puderam coexistir e se articular um com o

\footnotetext{
${ }^{2}$ Foucault, As palavras e as coisas, p. 536.
} 
outro"3. Entretanto, Foucault não parece estar certo de que ou bem a filosofia deve pensar o homem, ou bem ela deve pensar a linguagem, como se não fosse possível pensar, a um só tempo, o homem e a linguagem.

Em As palavras e as coisas, portanto, o futuro da filosofia ainda parece estar em aberto. Nesse sentido, a via que o filósofo vê diante de si, aquela do retorno à linguagem que contorna a questão do homem (o estruturalismo e o experimentalismo da linguagem, por exemplo), não deixa de ser somente uma via possível para o futuro da filosofia. Talvez pudesse existir uma outra via: a de uma filosofia que conciliasse uma reflexão sobre o homem e uma sobre a linguagem. E nos diz Foucault: "nada nos pode dizer, de antemão, de que lado a via está aberta"4. O futuro da filosofia poderia estar, então, diante de duas opções. Uma seria a via que conciliaria homem e linguagem, e é da seguinte maneira que Foucault anuncia essa opção: "Será nossa tarefa no porvir a de avançarmos em direção a um modo de pensamento, desconhecido até o presente em nossa cultura, e que permitiria refletir ao mesmo tempo, sem descontinuidade nem contradição, sobre o ser do homem e sobre o ser da linguagem?"ㄷ. A outra via seria a que mantém separada a reflexão sobre o homem e sobre a linguagem, e é da seguinte maneira que o filósofo se indaga a respeito dela:

\footnotetext{
Mas pode ser também que esteja para sempre excluído o direito de pensar ao mesmo tempo o ser da linguagem e o ser do homem; pode ser que haja aí como que uma indelével abertura (aquela em que justamente existimos e falamos), de tal forma que seria preciso rejeitar como quimera toda antropologia que pretendesse tratar do ser da linguagem, toda concepção da linguagem ou da significação que quisesse alcançar, manifestar e libertar o ser próprio do homem ${ }^{6}$.
}

Gostaria de defender a hipótese de que, diante das duas opções que Foucault aponta como vias para o futuro da filosofia, o filósofo decide-se ele mesmo em percorrer aquela que, segundo ele, ainda era desconhecida até então: a via que concilia uma reflexão sobre o homem com uma reflexão sobre a linguagem. Mas essa conciliação não significará nem um retorno à antropologia nos moldes da analítica da finitude (ou seja, não significará uma ressuscitação do homem), nem um apelo a uma reflexão sobre a linguagem nos moldes do estruturalismo ou da filosofia analítica; ela não será uma reflexão estritamente ontológica sobre o ser próprio do homem ou sobre o ser próprio da linguagem. Nesse sentido, a maneira como Foucault pensará o ser do homem não poderá se confundir com a maneira que as analíticas da finitude pensaram o homem. Pois se Foucault pensará o homem em sua relação com a linguagem e com a representação, é justamente isso que as analíticas da finitude evitaram fazer; para elas o homem está precisamente ali onde não há

\footnotetext{
${ }^{3}$ Foucault, As palavras e as coisas, p. 468.

${ }^{4}$ Ibidem.

${ }^{5}$ Ibidem.

${ }^{6}$ Ibidem.
} 
representação ou linguagem possível. Por outro lado, o questionamento sobre a linguagem levado a cabo por Foucault não significará um retorno a um formalismo puro. E é aqui que o filósofo se diferenciará das reflexões formais sobre a linguagem; pois se para essas fillosofias não está em questão a existência e o ser do homem, mas somente o formalismo das estruturas linguísticas, para Foucault a linguagem interessa na medida em que ela é usada pelos homens e provoca efeitos em seu ser. Assim, se estamos aqui defendendo que Foucault desenvolve uma filosofia que concilia linguagem e homem, é importante ter em mente que não se trata de uma reflexão sobre as condições de possibilidade da linguagem em geral, nem sobre as condições de possibilidade em geral, lógicas ou ontológicas, do homem. A meu ver, é justamente a recusa do transcendental, recusa não de sua existência, mas recusa enquanto objeto a ser conhecido, que marca a singularidade de Foucault tanto em relação à filosofia que lhe precedeu quanto em relação àquela que lhe é contemporânea.

A hipótese de que a filosofia de Foucault consiste numa reflexão que concilia uma reflexão sobre o homem e uma reflexão sobre a linguagem deve, então, respeitar duas exigências:

1) deve falar do homem, sem falar do homem. Ou seja, deve falar do ser do homem, contornando a questão e o problema do homem tal como aparece nas analíticas da finitude;

2) deve falar da linguagem, sem cair num formalismo puro ${ }^{7}$.

Parece-me que é a noção de uso que permite a Foucault cumprir essas duas exigências. Noção que encontramos já em História da loucura e que na tese complementar, "Introdução à Antropologia", recebe atenção especial. Em seu comentário sobre a antropologia kantiana, percebemos que a noção de uso tal como Foucault a utiliza é de forte inspiração kantiana. Ao que parece, Foucault encontra na Antropologia de um ponto de vista pragmático uma espécie de modelo para uma reflexão filosófica sobre o homem que não cai nas aporias e nas contradições de uma analítica da finitude. Isso porque a antropologia pragmática se interessa mais em descrever os usos que podemos e devemos ter de nossas representações do que encontrar um fundamento (encontrar a natureza da natureza humana) para os usos, legítimos e ilegítimos, que fazemos de nós mesmos.

Ora, em seu livro de 1969, A arqueologia do saber, a noção de uso é central para compreendermos o que Foucault entende por discurso e como este se diferencia de inúmeras filosofias e discussões sobre a linguagem e sobre a representação. O discurso, nesse contexto, deverá ser compreendido como uso que fazemos da linguagem. Esse uso, porém, que não se limita

\footnotetext{
7 Poderíamos citar aqui uma passagem em que Foucault procura se afastar do que é, segundo ele, a concepção formalista do estruturalismo: "Diferentemente daqueles que chamamos estruturalistas, eu não estou interessado nas possibilidades formais oferecidas por um sistema como a língua (...) meu objeto não é a linguagem, mas o arquivo, quer dizer, a existência acumulada de discursos". (Foucault, "Sur le façon d'écrire l'histoire", in Dits et écrits I, p. 623). De agora em diante esta obra será abreviada $D E I$ e $D E I I$.
} 
ao campo linguístico da utilização de palavras e das regras linguísticas, mas engobla também uma séria de outras práticas que estão envolvidas na formação de um discurso tido como verdadeiro, como as práticas de construção dos sujeitos de enunciação e as práticas de construção dos objetos a serem conhecidos.

Porém, se o empreendimento filosófico de Foucault avizinha-se da Antropologia de um ponto de vista pragmático na medida em que traz à tona o tema do uso, nosso autor não se mantém totalmente fiel a ela. No lugar do dever moral exigido pela antropologia kantiana (dever moral que coloca a humanidade como justificativa para os usos legítimos que fazemos de nossas faculdades mentais), Foucault recorrerá a Nietzsche para explicar os interesses que estão por trás dos usos que fazemos de nossos conhecimentos. Ao invés de contar com uma teoria do sujeito que pensa as possibilidades da ação livre em termos transcendentais e em termos de totalidade (para Kant, agir livremente significa agir tendo em vista a razão, mais especificamente, tendo em vista a ideia transcendental de humanidade), Foucault contará com a teoria nietzschiana do poder a fim de pensar a possibilidade de liberdade em termos empíricos e em termos de multiplicidade (tratar-se-á, pois, de pensar as possibilidades concretas de liberdade que se têm no interior das inúmeras relações reais de luta que sustentam o saber, o discurso e o conhecimento). Com isso, procuraremos mostrar que, se é verdade que a filosofia de Foucault consiste numa reflexão sobre a linguagem e sobre o homem, essa conciliação deve-se, no fim das contas, à maneira inusitada, e original, em que o pensamento de Nieztsche aparece como complementar ao pensamento de Kant; mostrar que a perda do transcendental não necessariamente significa um prejuízo à filosofia, uma vez que a sua suspensão pode abrir espaço para a valorização do empírico, da vida, enfim, de nossa existência concreta e real.

Nosso trabalho está dividido em duas partes. Na primeira parte, nossa análise estará centrada nos textos da década de 60 que tratam do método arqueológico e evidenciam a inspiração kantiana de Foucault: "Introdução à Antropologia" (1961), As palavras e as coisas (1966) e A arqueologia do saber (1969). Neste momento, tratar-se-á de analisar basicamente três questões: 1) o surgimento do problema do homem enquanto duplo empírico-transcendental, 2) como a antropologia kantiana fala do homem sem cair nas mesmas aporias que as analíticas da finitude, 3) como a arqueologia foucaultiana supera a questão do homem por meio de uma análise dos usos da linguagem. Na segunda parte do trabalho, o foco estará nos textos do início da década de 70 dedicados ao método genealógico e à influência nietzschiana: A ordem do discurso (1970), Leçon sur la Volonté de savoir (1971) e "Nietzsche, a genealogia, a história" (1971). Aqui, será preciso averiguar essencialmente duas coisas: 1) a importância do paradigma nietzschiano da vontade de saber que pensa sobre a 
maneira como nos relacionamos com nossas representações sem recorrer a uma teoria do sujeito; 2) a teoria foucaultiana da correlação entre saber e poder como condição de possibilidade para pensar a relação entre homem e linguagem, sujeito e discurso, em termos de liberdade. 


\section{PRIMEIRA PARTE \\ KANT E A ARQUEOLOGIA}




\section{CAPÍTULO 1. O PROBLEMA DO DUPLO EMPÍRICO-TRANSCENDENTAL NAS ANALÍTICAS DA FINITUDE}

Comecemos por tentar situar esse livro tão difícil quanto polêmico que é As palavras e as coisas. Creio que podemos começar do início, do prefácio. É famosa a citação que Foucault faz de um texto de Borges sobre uma certa enciclopédia chinesa. Nesse texto de Borges, diz Foucault, lemos:

os animais se dividem em: a) pertencentes ao imperador, b) embalsamados, c) domesticados, d) leitões, e) sereias, f) fabulosos, g) cães em liberdade, h) incluídos na presente classificação, i) que se agitam como loucos, j) inumeráveis, $\mathrm{k}$ ) desenhados com um pincel muito fino de pêlo de camelo, 1) et cetera, $\mathrm{m}$ ) que acabam de quebrar a bilha, n) que de longe parecem moscas ${ }^{8}$.

Como na maioria de seus prefácios, Foucault aqui não deixa de surpreender seu leitor com riso e uma certa inquietude. Afinal, o que essa enciclopédia chinesa tem a ver com uma arqueologia das ciências humanas? Ora, resolvi iniciar a apresentação de As palavras e as coisas justamente por esse trecho porque acredito que ele nos dá algumas pistas sobre o sentido geral do livro.

Chama a atenção que um livro publicado em 1966, no auge do estruturalismo francês, iniciese justamente com o tema da classificação e da taxinomia. Lembremos, pois, que é de 1962 o livro de Lévi-Strauss, $O$ pensamento selvagem, que expõe em detalhes o objeto de estudo da antropologia estrutural, qual seja, a maneira como diferentes culturas ordenam e dão sentido ao mundo por meio da classificação e da nomeação9 ${ }^{9}$ Mas, se é assim, se, desde o início de seu livro, Foucault, a partir do texto de Borges, faz uma referência, mesmo que implícita, ao estruturalismo, isso significa que nosso autor é ele mesmo um estruturalista? Se o prefácio indica que também Foucault irá se adentrar no tema da ordem, da classificação e da ideia do que está fora dela é "impensável” e causa estranheza, isso necessariamente o filia a essa corrente de pensamento? Não nos interessa, no momento, dar uma resposta definitiva a essa pergunta ${ }^{10}$. Vale-nos mais agora perceber o contexto geral em que As palavras e as coisas estão inseridas. E se optamos por começar pelo início do livro

\footnotetext{
${ }^{8}$ Foucault, As palavras e as coisas, p. IX.

${ }^{9}$ Cf., por exemplo, Lévi-Strauss, O pensamento selvagem, p. 24: “A verdadeira questão não é saber se o contato de um bico de picanço cura as dores de dente mas se é possível, de um determinado ponto de vista, fazer 'irem juntos' o bico do picanço e o dente do homem (congruência cuja fórmula terapêutica constitui apenas uma aplicação hipotética entre outras), e, através desses agrupamentos de coisas e de seres, introduzir um princípio de ordem no universo. Qualquer que seja a classificação, esta possui uma virtude própria em relação à ausência de classificação. [...] Ora, essa exigência de ordem constitui a base do pensamento que denominamos primitivo, mas unicamente pelo fato de que constitui a base de todo pensamento, pois é sob o ângulo das propriedades comuns que chegamos mais facilmente às formas de pensamento que nos parecem muito estranhas".

${ }^{10}$ Cf. Jean Zoungrana, Michel Foucault un parours croisé: Lévi-Strauss, Heidegger. Neste livro, o autor realiza um rico levantamento bibliográfico sobre inúmeras discussões e debates que se desenrolaram em torno da questão do estruturalismo de Foucault.
} 
foi somente para lembrar da presença do estruturalismo desde suas primeiras páginas. Digo desde suas primeiras páginas, pois a meu ver, a discussão com o estruturalismo está presente até o final. Lembremos, pois, que no último capítulo, a etnologia, ao lado da psicanálise lacaniana, terá papel de destaque no que diz respeito a análise das ciências humanas. Nesse sentido, podemos dizer que As palavras e as coisas é um livro que procura compreender não só o nascimento das ciências humanas, mas mais especificamente o nascimento daquelas ciências que marcam o presente histórico de Foucault, ou seja, as ciências humanas de cunho estruturalista: a psicanálise lacaniana e a antropologia estrutural.

Dito isso, ou seja, tendo situado brevemente o livro de Foucault no interior da temática estruturalista, passemos ao último capítulo do livro, intitulado "As ciências humanas", para retomar outras indicações que nos permitam compreender como, para Foucault, o estruturalismo se situa frente às ciências humanas em geral e qual o lugar destas ao lado da filosofia e das demais ciências, como a física, a matemática, a biologia, a economia e a linguística. Tudo isso, enfim, para melhor entender de onde Foucault nos fala e do que exatamente nos fala.

\section{O campo epistemológico das ciências humanas}

$\mathrm{O}$ capítulo $\mathrm{X}$ nos fala sobre o lugar das ciências humanas frente às outras ciências (matemática, física, biologia, economia e filologia), e frente à filosofia. Em primeiro lugar, vale lembrar que, segundo Foucault, antes da Idade Moderna não existia nada que pudesse se aproximar das ciências do homem, nada que pudesse prescrever essas novas ciências prestes a aparecer:

nenhuma filosofia, nenhuma opção política ou moral, nenhuma ciência empírica, qualquer que fosse, nenhuma observação do corpo humano, nenhuma análise da sensação, da imaginação ou das paixões, jamais encontrou, nos séculos XVII e XVIII, alguma coisa como o homem ${ }^{11}$.

De acordo com o filósofo, o campo de saber na Idade Clássica era perfeitamente homogêneo pois procedia a partir de um ideal de ordenação ${ }^{12}$. Na modernidade, contudo, o campo do saber se fragmenta basicamente em três dimensões diferentes. Numa primeira dimensão há as ciências matemáticas e físicas; numa segunda, há as ciências empíricas (biologia, economia e linguística) e, por fim, diz Foucault, há a dimensão da reflexão filosófica que, quando reflete sobre o domínio das ciências empíricas, dá origem à filosofia da vida, do homem alienado e das formas simbólicas. Além disso, ainda no domínio da filosofia, Foucault nos fala da reflexão de cunho ontológico que

\footnotetext{
${ }^{11}$ Foucault, As palavras e as coisas, p. 476.

12 Cf. Foucault, As palavras e as coisas, p. 478.
} 
pensa sobre o ser da vida, da vontade e da palavra $^{13}$. Por fim, haveria ainda na filosofia uma reflexão que a aproxima das ciências matemáticas e que engendraria as reflexões formalistas.

Note-se, porém, que desse "triedro de saberes" (ciências dedutivas, ciências empíricas e filosofia), as ciências humanas estão excluídas. Ora, dirá Foucault, o lugar das ciências humanas estará justamente no cruzamento dessas três dimensões do saber. E o filósofo tira as consequências disso:

Essa situação [...] coloca-as [as ciências humanas] em relação com todas as outras formas de saber: têm o projeto, mais ou menos protelado, porém constante, de se conferirem ou, em todo caso, de utilizarem, num nível ou noutro, uma formalização matemática; procedem segundo modelos ou conceitos tomados à biologia, à economia e às ciências da linguagem; endereçam-se, enfim, a esse modo de ser do homem que a filosofia busca pensar ao nível da finitude radical, enquanto elas pretendem percorrê-lo em suas manifestações empíricas ${ }^{14}$.

Apesar de afirmar que as ciências humanas guardam relações com as ciências dedutivas, Foucault insiste que não se pode crer que uma ciência do homem surge quando pretensões matemáticas atingem um novo alvo, o homem: "a análise arqueológica não descortinou, no $a$ priori histórico das ciências humanas, uma forma nova das matemáticas ou um brusco avanço destas no domínio do humano"15. Muito pelo contrário, dirá Foucault, só foi possível o nascimento de uma ciência sobre o homem a partir do momento que o projeto de uma máthêsis universalis recuou: "foi o retraimento da máthêsis e não o avanço das matemáticas que permitiu ao homem constituir-se como objeto de saber"16. É graças a esse retraimento, dirá o filósofo, que novas positividades puderam surgir no campo do saber; novas positividades como a vida, o trabalho e a linguagem. Não que antes do século XIX não houvessem reflexões sobre esses temas, porém, eles passam a ser pensados de um modo diferente, e isso tanto pelas ciências empíricas (biologia, economia, linguística), como pela reflexão filosófica. Daí se explica, portanto, por que num livro sobre a arqueologia das ciências humanas tão pouco se fale propriamente de ciências humanas (de psicologia, de sociologia, etnologia ou psicanálise) e tanto se investigue no campo das ciências empíricas.

Com efeito, a maior parte do livro é dedicada ao surgimento das ciências empíricas e de seus novos objetos de estudo: a vida, o trabalho e a linguagem. Surgimento que se dá na passagem da

\footnotetext{
${ }^{13}$ Cf. Foucault, As palavras e as coisas, pp. 334-342. De acordo com Philippe Sabot, talvez pudéssemos pensar que Foucault, aqui, se refira a Bergson, Schopenhauer e Schleiermacher. Cf. Lire Les mots et les choses de Michel Foucaultl, p. 71.

${ }^{14}$ Foucault, As palavras e as coisas, p. 480.

15 Idem, p. 483.

${ }^{16}$ Idem, p. 484.
} 
Idade Clássica à Idade Moderna, na passagem da história natural, da análise das riquezas e da gramática geral para a biologia, a economia e a linguística.

Mas, como afinal compreender esse livro que se propõe a ser uma arqueologia das ciências humanas e que pouco fala das ciências do homem propriamente ditas? Qual o estatuto filosófico desse livro que, à primeira vista, não passa de uma análise histórica da ciência moderna? Ora, é aqui que é preciso compreender a importância dos dois últimos capítulos do livro ${ }^{17}$.

Como já indicamos, é no capítulo X que Foucault situa as ciências humanas frente aos outros saberes. E se, como vimos, o lugar das ciências humanas é ao lado do chamado triedro dos saberes, não é de se estranhar que para compreender o nascimento das ciências do homem seja preciso antes entender como se configuram na modernidade esses três outros domínios do saber: as ciências dedutivas, as ciências empíricas e a filosofia.

Sobre as ciências dedutivas, porém, Foucault pouco ou quase nada fala; sobre a reflexão filosófica, parece dedicar especialmente o capítulo IX, e trata das ciências empíricas em quase todo o livro. Como, então, compreender esse descompasso ou desequilíbrio no que diz respeito ao tratamento desses três domínios que, a princípio, seriam igualmente importantes para a constituição das ciências humanas?

O próprio filósofo nos dá a justificativa. Segundo Foucault, a relação da matemática com as ciências humanas não é muito problemática; nesse sentido, crer que a ciência do homem define seu projeto no dia em que a matemática toma como objeto o homem "é tomar um contra-efeito de superfície pelo acontecimento fundamental"18. Por outro lado, muito mais problemática e complexa é a interação entre as ciências empíricas, a reflexão filosófica e as ciências humanas.

É certo, afirma Foucault, que as ciências humanas recorrem às ciências matemáticas, ainda mais quando se trata de pretensões científicas, porém, continua o filósofo: “As ciências humanas, com efeito, endereçam-se ao homem na medida em que ele vive, em que fala, em que produz"19.

\footnotetext{
17 Para Canguilhem é nesses dois capítulos que encontramos as grandes teses de As palavras e as coisas. (Cf. Canguilhem, "Mort de l'homme ou épuisement du Cogito?", p. 252).

${ }^{18}$ Foucault, As palavras e as coisas, p. 485. De acordo com Lebrun, poderíamos pensar que quando Foucault escreve isso ele tem em mente a ideia de máthêsis defendida por Husserl em A crise das ciências européias e a fenomenologia transcendental. Lebrun explica que, segundo Foucault, Husserl ao chamar a Idade Clássica de racionalista teria confundido Newton e Descartes, ou seja, o projeto de uma matematização sistemática do mundo e uma ciência universal da medida e da ordem. Para Descartes, a medida só seria um aspecto da ciência da ordem, da máthêsis, pois esta incluiria também o saber empírico que não tem nada de mecânico e matemático. Husserl teria então deformado a ideia de máthêsis ao afirmar que na Idade Clássica todo o saber vivia sob a influência de Galileu e de seu projeto de tudo conhecer através da matemática (Cf. Lebrun, "Note sur la phénoménologie dans Les mots et les choses", pp. 35-6). Segundo Lebrun, a pergunta de Foucault sobre a Idade Clássica difere daquela de Husserl. Não lhe interessa descobrir por que Galileu se impôs com tanta força (por que se pretendia tudo conhecer), mas como foi possível que um projeto como o de Galileu tenha existido (por que se tinha um tal projeto de ordenação do mundo, a máthêsis, que possibilitava uma certa relação não problemática entre ser e representação).
}

${ }^{19}$ Foucault, As palavras e as coisas, p. 485. 
Nesse sentido, as ciências humanas estão muito mais próximas da biologia, da economia e da linguística do que das ciências dedutivas: "o que as torna possíveis, com efeito, é uma certa situação de vizinhança em relação à biologia, à economia, à filologia (ou à linguística)" ${ }^{20}$. Mas, no que tange à relação das ciências humanas com a filosofia, o que podemos dizer sobre essa interação?

Segundo a configuração epistemológica apresentada por Foucault, as ciências humanas estão ligadas ao domínio da filosofia na medida em que conduzem, furtivamente, os objetos de estudo das ciências empíricas para o campo de uma certa reflexão filosófica, o campo das chamadas analíticas da finitude. Tal reflexão é aquela que, como vimos numa citação acima, "busca pensar ao nível da finitude radical". Aos olhos de Foucault, será justamente aí que estará o grande problema das ciências humanas, pois será aí que elas "antropologizarão" demais e correrão o risco de tornarem-se precárias e incertas ${ }^{21}$. Ora, essa "antropologização" pode também ser chamada de sono antropológico e, como veremos, poderá ser pensada em paralelo com o sono dogmático das metafísicas da Idade Clássica, denunciado por Kant. Mas, antes de compreendermos do que se trata exatamente esse sono do qual parece padecer não só as ciências humanas que ultrapassam os limites empíricos de suas disciplinas, mas também certa reflexão filosófica que extrapola igualmente o domínio de suas considerações ao se debruçar sobre a finitude radical do homem, façamos uma observação.

É de notar que nem toda ciência humana deve ser taxada pejorativamente como "antropologismo" ou "humanismo". Uma coisa, por exemplo, é o estudo das mitologias indoeuropeias tal como faz Dumézil ${ }^{22}$, que de maneira alguma se propõe a desvendar a natureza da natureza humana e outra, completamente diferente, diz Foucault, seria o "medíocre empreendimento de fundar uma psicologia dita 'clínica'" 23 que visaria, essa sim, a encontrar o fundamento do homem. E se, por um lado, é certo que Foucault economiza quando se trata de "dar nomes aos bois", e não deixa claro quais são exatamente as ciências humanas e as reflexões filosóficas que dormem no sono antropológico, por outro lado, ele é bastante preciso quando se trata de apontar os autores, as correntes e as escolas que não padecem desse mal. É o caso tanto da

\footnotetext{
${ }^{20}$ Foucault, As palavras e as coisas, p. 507.

${ }^{21}$ Cf., Foucault, As palavras e as coisas, p. 481.

22 Seria interessante fazer um estudo mais aprofundado sobre a influência de Dumézil para Foucault, porém, limitamonos aqui a fazer um pequeno apontamento: em uma entrevista de 1967, nosso autor afirma que a grande contribuição de Dumézil para o seu trabalho está no método comparativo que permite compreender a morfologia interna de um evento histórico. Assim, Foucault explica que, em As palavras e as coisas, os paralelismos que ele encontra entre diferentes saberes podem ser compreendidos, no que diz respeito ao método, conforme os isomorfismos que Dumézil vê entre, por exemplo, as lendas escandinávias, celtas e iranianas e a religião romana (Cf. Foucault, "Sur les façons d'écrire l'histoire", in DE I, p. 619).
}

${ }^{23}$ Foucault, As palavras e as coisas, p. 496. 
etnologia quanto da psicanálise ${ }^{24}$, mas também das filosofias analíticas e de muitos autores que na literatura pensam sobre o ser da linguagem, passando por Roussel, Artaud, Bataille e Blanchot ${ }^{25}$. Além disso, Foucault também indica qual o traço comum a todos esses novos saberes que estão imunes ao sono antropológico: todos eles contornam uma certa noção problemática de homem ao direcionarem suas investigações ao campo da linguagem ${ }^{26}$.

Resumamos, então, a configuração do campo epistemológico no qual estão inseridas não só as ciências do homem mas também o próprio Foucault no momento em que ele escreve: surge na modernidade uma certa concepção de homem que será batizada, como veremos adiante, de duplo empírico-transcendental; este novo objeto do saber nasce da confluência de uma certa reflexão filosófica, as chamadas analíticas da finitude, que surgem da esteira do pensamento kantiano, e das novas ciências empíricas sobre o homem que o tomam como um ser que vive, trabalha e fala ${ }^{27}$. É somente essa nova concepção de homem que faz parte de, se assim podemos dizer, uma "má" antropologia e que estará fadada, segundo o diagnóstico de Foucault, à morte. Morte anunciada, como diz Foucault, desde Nietzsche ${ }^{28}$, passando por todos aqueles que, desde o final do século XIX, contornaram a questão do ser homem e passaram à questão do ser da linguagem. E feito o diagnóstico basta saber se o próprio Foucault conseguirá ele mesmo ultrapassar a questão problemática do homem e como ele alcançará tal proeza. Este é, pois, um dos grandes objetivos deste trabalho. Mas, centremo-nos, por ora, no capítulo IX de As palavras e as coisas a fim de esclarecer qual é o problema do homem.

\section{O homem}

No famoso capítulo IX de As palavras e as coisas, intitulado "O homem e seus duplos", Foucault afirma: “o limiar de nossa modernidade não está situado no momento em que se pretendeu

\footnotetext{
24 Diz Foucault: "nada é mais estranho à psicanálise que alguma coisa como uma teoria geral do homem ou uma antropologia" (Foucault, As palavras e as coisas, p. 521).

${ }^{25}$ Cf. Foucault, As palavras e as coisas, pp. 531-2.

${ }^{26}$ Cf. Foucault, As palavras e as coisas, pp. 526 e sgg.

27 “O que se passou na época de Ricardo, de Cuvier e de Bopp, esta forma de saber que se instaurou com a economia, a biologia e a filologia, o pensamento da finitude que a crítica kantiana prescreveu como tarefa para a filosofia, tudo isto forma ainda o espaço imediato de nossa reflexão. É neste lugar que nós pensamos." (Foucault, As palavras e as coisas, p. 533)

${ }^{28}$ Cf. Foucault, As palavras e as coisas, p. 534.
} 
aplicar ao estudo do homem métodos objetivos, mas no dia em que se constituiu um duplo empírico-transcendental a que se chamou homem"29.

Tal asserção nos coloca imediatamente com a tese do autor: a origem das ciências humanas não está tanto na busca por um conhecimento objetivo do homem e da natureza humana, já que, como sabemos, esse conhecimento já existia antes do século XIX, mas no aparecimento de uma nova figura que, essa sim, mereceria ser chamada de homem. Foucault insiste: “O 'humanismo' do Renascimento, o 'racionalismo' dos clássicos podem realmente ter conferido um lugar privilegiado aos humanos na ordem do mundo, mas não puderam pensar o homem" 30 . E ainda: "Antes do fim do século XVIII, o homem não existia [...] não era possível naquele tempo que se erguesse, no limite do mundo, essa estatura de um ser cuja natureza (a que o determina, o detém e o atravessa desde o fundo dos tempos) consistisse em conhecer a natureza e, por conseguinte, a si mesmo como ser natural" 31 .

Procuraremos aqui lançar luz sobre essa nova figura da modernidade caracterizada como um duplo empírico-transcendental, e compreender de que maneira ela se relaciona com a ideia problemática de que a natureza do homem consiste em conhecer a si mesmo como ser natural.

Em diversos momentos de seu percurso filosófico, Foucault afirma que a modernidade, da qual ainda somos contemporâneos, inicia-se com Kant ${ }^{32}$. O filósofo alemão seria, antes de tudo, o pai do transcendental; aquele que teria pela primeira vez colocado, de maneira sistemática, a questão das condições transcendentais de possibilidade.

No domínio da filosofia, Foucault deriva duas tradições filosóficas a partir da novidade kantiana do transcendental: 1) uma que se deteria nos questionamentos da Crítica da Razão Pura e se limitaria à pergunta pelas condições de possibilidade de um conhecimento verdadeiro (Foucault chama essa tradição de filosofia analítica da verdade e ela provavelmente diz respeito às reflexões mais formalistas que ao longo do século XIX e XX se avizinharam mais das matemáticas dos que das ciências empíricas); e 2) outra tradição, que igualmente nasce com a descoberta do

\footnotetext{
${ }^{29}$ Foucault, As palavras e as coisas, p. 439.

${ }^{30}$ Ibidem.

${ }^{31}$ Idem, p. 425 e p. 428.

32 Cf. Foucault, As palavras e as coisas, p. 418. Vale notar aqui, como esclarece Lebrun, que ao situar nossa modernidade em Kant Foucault está mais uma vez contrapondo-se a Husserl que não teria percebido a originalidade do filósofo alemão e que teria situado nossa modernidade em Descartes. De acordo com Lebrun, Foucault chama atenção para o fato de Husserl não ter se dado conta que Kant passa de uma análise da ordem das coisas representadas, tal como faz Descartes, para uma analítica das condições de possibilidade da representação. (Cf. Lebrun, "Note sur la phénoménologie...", p. 41).
} 
transcendental, mas que se coloca a pergunta "quem somos nós nos tempos de hoje"33, isto é, que coloca a questão de nosso ser histórico e empírico ao lado do questionamento transcendental ${ }^{34}$. E se a primeira corrente filosófica é aquela das linguagens formais e do vínculo com a matemática ${ }^{35}$, essa segunda corrente é aquela que se aproxima da biologia, da economia e da linguística para pensar o homem como ser que vive, trabalha e fala.

É seguramente essa segunda tradição kantiana que nos interessa aqui. Não somente porque é a ela que Foucault se filia, mas porque é justamente de dentro dela que surgirão as ditas "analíticas da finitude".

Aqui, então, é preciso atenção. Pois, se é verdade que Kant inaugura uma reflexão sobre o homem enquanto condição de possibilidade, isto é, enquanto transcendental, e enquanto ser empírico e histórico, é importante salientar que existem diferentes maneiras de pensar a relação entre o empírico e o transcendental. No próprio Kant, haveria uma grande diferença entre a maneira como o transcendental e o empírico aparecem lado a lado na Antropologia de um ponto de vista pragmático ou na Lógica e nas Obras Póstumas ${ }^{36}$. Segundo Foucault, seria somente nessas duas últimas que o homem apareceria como um duplo. Na Antropologia, apesar de haver a presença do transcendental, o homem não será considerado ontologicamente um duplo. A diferença entre empírico e transcendental estará sempre resguardada ao plano do conhecimento, aos dois modos distintos que é possível conhecer o homem: transcendentalmente ou empiricamente.

Mas, se, segundo Foucault, a antropologia pragmática de Kant apesar de abordar o homem no mundo, na história e em sua empiricidade, não deixa de manter as devidas distinções entre o empírico e o transcendental, Husserl e a fenomenologia em geral, porém, por outro lado, incorreriam na confusão das duas ordens ${ }^{37}$. E é aqui que vale situar a distância entre Foucault e a fenomenologia. Pois se é verdade que ambos estão na esteira da pergunta kantiana pelo empírico e

\footnotetext{
${ }^{33}$ Foucault, “Qu'est-ce que les Lumières?”, in DE II, pp. 1506-7.

34 A essa segunda tradição, além do próprio Foucault, também pertenceriam, segundo nosso autor: Fichte, Hegel, Nietzsche, Max Weber, Husserl, Heidegger e os autores da Escola de Frankfurt. Cf. Foucault, "La technologie polithique des individus", in $D E I I$, p. 1633.

${ }^{35}$ Cf. Foucault, As palavras e as coisas, p. 531.

${ }^{36} \mathrm{Cf}$. Foucault, "Introduction à l'Anthropologie", pp. 46 e ssg.

${ }^{37}$ Cf. Foucault, "Introduction à l'Anthtopologie", pp. 67-8: "Certamente, fazia parte do projeto inicial de Husserl, tal como testemunham as Investigações Lógicas, liberar as regiões do a priori das formas que as reflexões sobre o originário o haviam confiscado. Entretanto, uma vez que o próprio originário jamais pode ser o solo de sua própria liberação, foi ao originário concebido na espessura das sínteses passivas e do já aí que o esforço para escapar ao originário concebido como subjetividade imediata afinal remeteu. A redução só se abria para um transcendental de ilusão e não lograva desempenhar o papel a que era destinada - e que consistia em ocupar o lugar de uma reflexão crítica elidida [...] a problemática do Welt [mundo] e da In-der-Welt [no mundo] não podia escapar à hipoteca da empiricidade. Todas as psicologias fenomenológicas e outras variações sobre a análise da existência são o morno testemunho disto".
} 
pelo transcendental no homem, ou ainda, pela pergunta sobre o homem no mundo, Foucault estaria mais próximo do tipo de questionamento da antropologia pragmática, que mantém a distinção entre empírico e transcendental, do que do lado daquelas reflexões que tomam um pelo outro. E vale notar que, segundo Foucault, não teria sido somente a fenomenologia que teria apresentado de maneira ambígua o empírico e o transcendental no homem. Esse teria sido também o traço distintivo de diversos outros saberes que desde o início do século XIX se propuseram a pensar o homem enquanto ser que vive, trabalha e fala.

Sono antropológico é o nome que nosso filósofo dá a esse mal de que padece toda reflexão que, durante os dois últimos séculos, ao se propor a pensar o homem, opera a confusão entre o empírico e o transcendental ${ }^{38}$.

É certo que colocar sob a insígnia de sono antropológico todas as reflexões sobre o homem que se desenvolveram ao longo de dois séculos é uma tarefa um tanto arriscada, assim como pretensiosa. O risco é aquele de colocar sob um mesmo rótulo autores e perspectivas tão diferentes: a generalização é sempre imprecisa e deixa de fora as exceções. Beatrice Han nos lembra que Sartre, por exemplo, em seus primeiros escritos, mais notadamente em $A$ transcendência do ego, teria justamente procurado manter a distinção entre empírico e transcendental "insistindo na atividade pura da consciência e na impossibilidade de identificá-la com qualquer conteúdo empírico" 39 . Por outro lado, o pretensioso na empresa foucaultiana está no fato de ele se colocar numa situação privilegiada, afinal de contas, se ele denuncia o sono antropológico, é porque ele mesmo já está acordado. Não nos interessa aqui, contudo, verificar a validade dessa pretensão, nem tampouco se Foucault foi ou não injusto em suas acusações. A questão aqui é, antes, compreender a possível confusão entre empírico e transcendental.

A confusão entre empírico e transcendental nas ciências empíricas

No já citado capítulo IX de As palavras e as coisas, Foucault nos oferece diferentes contornos para a confusão empírico-transcendental operada pela reflexão sobre o homem. E, a nosso ver, é no domínio das ciências empíricas que tal confusão aparece de modo mais claro.

\footnotetext{
${ }^{38}$ Foucault, As palavras e as coisas, p. 471.

${ }^{39}$ Han, “Introduction à l'Anthropologie", p. 8.
} 
Retomemos então primeiramente a confusão apresentada por Foucault no nível das ciências empíricas para depois compreendermos de que modo tal confusão está presente também na reflexão filosófica.

Para a biologia, a vida, ao mesmo tempo que é seu objeto de estudo, é também considerada aquilo que possibilita a vida de qualquer ser vivo; o trabalho e o modo de produção, que são objetos de análise dos economistas, são, ao mesmo tempo, aquilo que possibilita ao sujeito trabalhar e produzir; por fim, a língua é, a um só passo, tanto o objeto de um saber empírico que se pergunta pela língua que falamos quanto aquilo que possibilita a fala de qualquer sujeito.

A figura ambígua que começa a se esboçar aí é a de um homem que é princípio e meio de uma vida, de um modo de produção e de uma língua. A partir de uma consideração objetiva, isto é, tomando o homem como objeto, pode-se dizer que ele é a maneira como vive, os objetos que produz e a língua que fala. Neste contexto, o homem aparece em sua positividade empírica, diz Foucault. Essa positividade, porém, ao mesmo tempo que é aquilo que define o ser do homem, não diz o que ele é. A partir de minhas positividades empíricas, acusa Foucault, "posso dizer tanto que sou quanto que não sou tudo isso" ${ }^{40}$. Expliquemos.

Se, por um lado, o homem é positiva e empiricamente um certo modo de vida, um modo de produção e uma língua, por outro lado, ele não é nem essa vida, nem esse trabalho, nem essa língua, já que tudo isso não nasce nele, nem dele: seu modo de vida pertence antes à sua espécie do que a ele mesmo, a maneira como trabalha e produz é determinada pela história de seu tempo, a língua que fala é dada por sua cultura. E, se é assim, se minhas determinações ou positividades empíricas são mais antigas do que eu e não me pertencem, estou desde o início articulado com alguma coisa que me é estranha e jamais sou contemporâneo de minha origem ${ }^{41}$. E se, por um lado, o homem é simplesmente um meio, uma peça intermediária que atualiza, sedia ou reanima um "já começado", um já começado de um certo tipo de vida, de uma determinada organização produtiva e de regras linguísticas específicas, por outro lado, não se pode negar que ele é princípio dessa vida, desse trabalho e dessa língua que nele se atualizam. Ou seja, ele é, ao mesmo tempo, esse objeto determinado por um certo modo de vida, um certo modo de produção e uma certa língua, e esse sujeito que funciona como condição de possibilidade para que uma língua seja falada, uma vida exista e um trabalho seja executado.

Ora, o duplo do homem começa então a aparecer justamente quando aquilo que no indivíduo servia simplesmente como meio (aquilo que o determina enquanto objeto), começa a funcionar

\footnotetext{
${ }^{40}$ Foucault, As palavras e as coisas, p. 448.

${ }^{41}$ Cf. Foucault, As palavras e as coisas, p. 469.
} 
como princípio (como atividade de um sujeito); quando sua positividade empírica (sua vida, seu trabalho e sua língua), que não lhe pertence, passa a funcionar como princípio da própria vida, do trabalho e da fala. Temos aqui, com as palavras de Foucault, a reduplicação, a repetição ou a dobra do empírico no nível do transcendental. A vida, investigada em sua manifestação empírica e objetiva, tem também o estatuto de transcendental já que é, em suas formas de funcionamento, a condição de possibilidade de todo ser vivo. O trabalho em suas formas determinadas de organização é também a condição de possibilidade para qualquer produção. Por fim, a língua que falamos é também a condição de possibilidade para a nossa fala.

Mas o que vemos aqui? O empírico funcionar como transcendental. Eles são uma e a mesma coisa. Além disso, vemos também que esse modo de ser indistinto entre empírico/transcendental só define de maneira negativa o ser de cada homem: tudo aquilo que ele diz do homem não pertence ao homem, mas antes o que lhe escapa. Pois, se é verdade que minha forma de vida me é dada por um corpo que é meu, este corpo que é o meu, que é a condição de possibilidade de toda e qualquer vida, já tem um modo de funcionamento que é o mesmo daquele observado empiricamente; um modo de funcionamento que não foi dado por mim, mas a mim. É verdade que o meu trabalho deve ter como condição de possibilidade um desejo que é meu, no entanto, esse meu desejo é o mesmo que aquele que se manifesta empiricamente quando desejo algo: um desejo determinado por um sistema que me escapa. Por fim, também é certo que a língua que eu falo deve ser precedida por alguma coisa em mim que a possibilite. Porém, essa condição de possibilidade, esse transcendental, os meus pensamentos falantes, por exemplo, diz Foucault, já são uma repetição da língua que eu falo e que não me pertence.

Assim, é importante notar que esse estatuto de transcendental que se pretende dar às positividades empíricas, além de levar a essa circularidade indefinida entre condicionado/ condicionante e determinado/determinante, implica uma nova apreensão acerca da finitude humana: uma finitude alienada. Vejamos, então, mais de perto que nova figura é essa. E se até aqui tentamos mostrar a confusão entre empírico e transcendental nas considerações acerca do homem enquanto objeto das ciências empíricas, agora é a vez da reflexão filosófica nos explicar do que se trata essa confusão e de que modo ela está ligada a uma nova apreensão da finitude humana. 
Antes de entrar na discussão da finitude em Foucault, propomos uma pequena digressão para situar minimamente este debate no interior do cenário filosófico francês da época. Faremos breves apontamentos que futuramente pretendemos retomar de modo mais detalhado.

Vale notar que a problematização da questão da finitude não é preocupação somente de Foucault e que ela não aparece repentinamente no livro de 66. Em um curso realizado na École Normale Supérieure, intitulado "Problèmes d'Anthropologie", entre os anos de 1954 e 1955, época das primeiras publicações de Foucault (Doença mental e personalidade é de 1954), o tema já aparece. Cerca de 5 anos depois, o mesmo tema volta a aparecer na tese complementar, apresentada em 1961. Além disso, vale também notar que em ao menos dois outros filósofos, professores e amigos de Foucault, pode-se encontrar uma discussão profunda acerca do tema: em Jules Vuillemin e em Jean Hypollite.

Jules Vuillemin, que se forma na École Normale em 1943, poucos anos antes da entrada de Foucault na mesma instituição, é pesquisador do CNRS (Centre national de la recherche scientifique) de 1944 a 1950. Talvez nesse período Foucault e Vuillemin tenham estreitado laços visto ser o período de formação de Foucault. Em 50, Vuillemin torna-se professor em ClermondFerrand até 1962, onde Foucault passará a lecionar a partir de 60 a convite do próprio Vuillemin, o que mostra uma certa proximidade entre os dois. O fato é que em 1954 é publicado o livro de Vuillemin: L’héritage kantian et la revolution copernicienne: Fichte, Cohen, Heidegger. Neste livro, o estudioso de Kant analisa como se deu a interpretação de Kant à luz da leitura que Hegel fez do filósofo na Fenomenologia do Espírito, na parte "A visão moral do mundo". Em linhas gerais, podemos dizer que, de acordo com Vuillemin, Hegel vê em Kant uma contradição na relação entre liberdade e natureza, ou entre o dever moral e a efetividade moral. Para Vuillemin, o esforço da filosofia depois de Kant teria sido justamente o de salvar a filosofia transcendental ou a revolução copernicana dessa contradição.

Com poucas palavras, podemos dizer que a contradição da "visão moral do mundo" de Kant aponta para o problema da relação entre finito e infinito, entre homem e Deus. Segundo Hegel, é contraditória a síntese que Kant propõe entre a pureza da lei moral e a efetividade da moralidade. Para garantir que os homens ajam moralmente, Kant deve supor a existência de um legislador superior que garanta a adequação entre o conhecimento puro do dever moral (liberdade) e a ação determinada pela natureza (natureza). Sem a existência desse Deus, nada garantiria que do conhecimento da lei moral se seguiria a ação moral. Deriva-se disso a grande contradição dessa 
visão moral do mundo: ao situar fora do sujeito, em Deus, a síntese entre a liberdade do sujeito e as determinações da natureza, Kant acaba contradizendo o princípio central de sua teoria moral, a autonomia. Por um lado, Kant afirma que a moralidade está na autonomia, no conhecimento da lei moral e do dever moral; por outro lado, se é Deus quem garante que a ação determinada pela natureza esteja de acordo com o conhecimento puro do dever, a efetividade moral se dá graças a um princípio de heteronomia. Confirma Vuillemin: “O postulado da existência de Deus consiste, então, em levar necessariamente a autonomia da Revolução copernicana à heteronomia da religião. Ao mesmo tempo que a lei moral me dá a consciência de minha liberdade, ela aparece inelutavelmente sob a forma de uma ordem divina"42.

Entretanto, é possível que a visão moral do mundo de Kant não seja assim tão contraditória. Se levarmos a sério a tese kantiana de que Deus é uma ideia, é preciso concluir que a síntese entre natureza e liberdade realizada pela figura de Deus é, no fim das contas, uma síntese feita pelo próprio sujeito por meio da ideia de Deus. Nesse sentido, é a ideia de Deus e não um Deus existente realmente fora do sujeito que garante a concordância, no campo da moralidade, do que é de direito e do que é de fato. A ideia de Deus, portanto, enquanto uma ideia da razão, antes de inserir um princípio de heteronomia na base da moralidade, reforça a tese de que a ação moral verdadeira é justamente aquela que segue a razão.

Vuillemin sugere, então, que Hegel toma como uma contradição a ser superada aquilo que deveria ser visto apenas como uma ambiguidade do sistema kantiano. Com efeito, diz Vuillemin, há um problema na visão moral do mundo de Kant. Ao colocar o princípio regulador da moralidade na ideia de Deus e não no próprio Deus, não se sabe se com isso glorificamos o homem ou destruímos Deus $^{43}$; se a razão prática é um humanismo ou um misticismo; se se trata ainda de uma metafísica do infinito ou de uma metafísica do finito. Ou seja, é a ambiguidade de se continuar pensando de maneira teológica no interior de um mundo ateu, de se continuar pensado em Deus quando se sabe que ele morreu; de continuar a insistir na investigação do infinito, quando se sabe que se deve permanecer nos limites da finitude.

Aquilo que em Kant era da ordem da ambiguidade ou da antinomia, porém, será tomado como contradição a ser superada. A relação entre finitude e infinitude deverá, então, assumir um sentido unívoco. Depois de Kant, pretender-se-á preservar a filosofia transcendental das metafísicas do infinito prenhes de religiosidade e que marcam o período clássico antes de Kant. Contudo, se,

\footnotetext{
42 Vuillemin, L'héritage kantian et la revolution copernicienne: Fichte, Cohen, Heidegger, p. 9.

${ }^{43}$ Ibidem.
} 
por um lado, a filosofia moderna evitará os prejuízos da metafísica clássica ocupando-se com a finitude humana, por outro lado, ela procurá compreender a essência eterna dessa mesma finitude. Por essa via, entretanto, a filosofia moderna se reconciliará, furtivamente, com a maneira clássica de fazer filosofia: a philosophia perenis ${ }^{44}$. É certo que ela parte da finitude, mas em última instância tem sempre em vista a infinitude. Deus está morto; o mundo é ateu, mas o pensamento ainda é teológico. E se não é mais possível fazer uma ontologia do infinito, já que Deus está morto, sua tentativa será fazer uma ontologia do finito que não deixa de considerar a infinitude no interior da própria finitude, o absoluto no interior do próprio sujeito ${ }^{45}$. Neste movimento é a própria filosofia que se torna a nova divindade. Conclui Vuillemin:

À l'époque classique la philosophie se présentait comme le complément de la théologie. La
philosophie moderne croit supprimer la religion quand, en réalité, elle veut en être le substitut. Car si
elle découvre la finitude, elle dévoile aussi l'essence éternelle de cette finitude [...] Dieu n'est plus,
mais la philosophie qui proclame l'inexistence de Dieu représente aussi la divinité nouvellete.

Como veremos mais adiante, esse é, pois, um livro que seguramente influenciou Foucault em suas teses sobre o destino da filosofia depois de Kant. Desde a introdução à Antropologia de um ponto de vista pragmático até As palavras e as coisas, o eco das teses de Vuillemin será evidente.

No que diz respeito à questão da finitude e à leitura que Foucault fizera de Kant, podemos ainda lembrar da importante influência que Jean-Hyppolite teve para Foucault. A relação entre os dois começa cedo, já que Hyppolite foi professor de Foucault no liceu Henri-IV, em 1945-6, no curso preparatório para entrar na École Normale. Em 47 é publicado Gênese e Estrutura da Fenomenologia do Espírito de Hegel, livro que certamente estava muito presente nas aulas sobre Hegel a que Foucault assistiu em 45, e também livro fundamental para Vuillemin que chega a afirmar em nota que suas análises de Hegel "seguem exatamente Hyppolite", principalmente a parte VI do livro, capítulo 1, "A visão moral do mundo"47. Em 52, Hyppolite publica Lógica e existência e em 54, ano em que Foucault leciona na École, Hyppolite torna-se diretor da instituição. Em 61, será Hyppolite o orientador da tese complementar sobre Kant. No livro de 52, Lógica e existência, nos parece que em sua segunda parte, “La pensée spéculative et la réflexion”, podemos encontrar mais pistas de uma reflexão que teria influenciado Foucault.

\footnotetext{
${ }^{44}$ Cf. Vuillemin, opus cit., conclusion, $§ 24$.

45 É o que acontece em Hegel, por exemplo, tal como esclarece Hyppolite: "a essência infinita se realiza na existência finita e a existência finita se eleva à essencialidade" (Hyppolite, Gênese e estrutura da Fenomenologia do espírito, p. 517).

46 Vuillemin, op. cit, p. 302.

${ }^{47}$ Cf. Vuillemin, op. cit, p. 3.
} 
Didier Eribon nos lembra que Foucault ao longo de sua vida reconhece sua dívida com Hyppolite e que numa entrevista publicada na Revue de méthaphysique et morale, em 1968, numa homenagem em ocasião da morte de Hyppolite, Foucault afirma que os problemas filosóficos de sua época foram expostos por Hyppolite em Lógica e existência ${ }^{48}$.

Além disso, não se pode esquecer das palavras finais pronunciadas por Foucault em sua aula inaugural no Collège de France, no momento em que toma o lugar de Hyppolite. Nesta ocasião, nosso autor afirma que Hyppolite teria sido aquele que ensinou uma nova tarefa da filosofia: uma tarefa sem término que se situa sempre diante de um horizonte infinito. Diante da impossibilidade de pensar a filosofia como totalidade, como algo capaz de se pensar e de se apreender no movimento do conceito, a filosofia passa a ter a tarefa de romper com as generalidades adquiridas e de entrar em contato com a não-filosofia. Aparece, então, segundo Foucault, o tema de uma filosofia do presente, “inquieta, móvel em toda sua linha de contato com a não-filosofia, não existindo senão por ela, contudo, e revelando o sentido que essa não-filosofia tem para nós"49. E talvez aqui Foucault justifique a importância de Hyppolite e seus ensinamentos e deslocamentos de Hegel. Diz Foucault: "a filosofia como pensamento inacessível da totalidade era para Jean Hyppolite aquilo que poderia haver de repetível na extrema irregularidade da experiência [...] assim, o tema hegeliano da consciência de si, ele o transformava em um tema da interrogação repetitiva"50. E ainda neste contexto de uma nova tarefa da filosofia sem pretensões totalitárias e sempre em contato com a não-filosofia, Foucault parece acenar àquilo que mais nos interessa aqui: a reflexão sobre a lógica e a existência. Hyppolite seria, pois, aquele que ao refletir sobre a psicanálise e sobre a lógica da lei do desejo, assim como sobre as matemáticas e a formalização do discurso, a teoria da informação e sua aplicação na análise do vivente, teria pensado sobre "todos os domínios a partir dos quais se pode colocar a questão de uma lógica e de uma existência que não cessam de atar e desatar seus laços" ${ }^{\prime 5}$.

\footnotetext{
${ }^{48}$ Cf. Eribon, Michel Foucault, p. 37.

${ }^{49}$ Foucault, $A$ ordem do discurso, p. 76.

${ }^{50}$ Idem, p. 75.

${ }^{51}$ Idem, p. 78.
} 


\section{A finitude em Foucault}

A questão da finitude humana aparece, em Foucault, sempre atrelada à questão do limite. Parece-me que podemos encontrar nos textos do filósofo ao menos três configurações dessa relação: a finitude tal como aparece em Descartes e na Idade Clássica em geral, a finitude tal como aparece em Kant, principalmente na Crítica da Razão Pura, e a finitude numa certa filosofia pós-kantiana, chamada por Foucault de analíticas da finitude.

Em sua leitura de Descartes e da Idade Clássica em geral, os limites ou a finitude do homem, de seu entendimento ou de sua sensibilidade, por exemplo, apareceriam sempre como reflexo de sua posição de inferioridade em relação a Deus. Nesse sentido, trata-se de uma finitude negativa que marca no homem aquilo que nele não é Deus. No curso "Problemas de Antropologia", ao analisar a filosofia clássica na figura de Descartes e Malebranche, Foucault nos lembra que o erro é, nesse período, a marca da nossa finitude, a marca de nossa distância em relação a Deus, de nossa imperfeição frente aos poderes infinitos de Deus. A finitude humana, assim, na figura do erro sinalizaria somente de maneira negativa os nossos limites, sinalizaria somente as perfeições divinas das quais somos desprovidos, aquilo que em nós está ausente. Lebrun em seu artigo "Transgredir a finitude" nos fala exatamente dessa finitude negativa que marca a Idade Clássica e esclarece: "relativamente ao saber divino, a finitude clássica designava tudo o que tolhia o acesso do homem à verdade. Qual o meio excelente de reconhecê-la? Os erros dos sentidos e da imaginação"52.

Contrária a essa finitude negativa que se define sempre em referência a uma metafísica do infinito, como diz Vuillemin ${ }^{53}$, em Kant a finitude humana aparece de maneira positiva e independente de uma ontologia do infinito. Será uma finitude positiva na medida em que irá fundamentar o conhecimento, que será constituinte de todo ser humano e que não será definido como o negativo do infinito e absoluto de Deus: os limites do nosso conhecimento são marcas positivas de nossa finitude. Foucault esclarece:

Até o final do século XVIII, que dizer, até Kant, toda reflexão sobre o homem é uma reflexão segunda em relação a um pensamento que, esse sim, é o primeiro e que é, digamos, o pensamento do infinito. [...] a partir de Kant, o infinito não é mais dado, não há senão a finitude, e é nesse sentido que a crítica kantiana levava consigo a possibilidade e o perigo de uma antropologia ${ }^{54}$.

A finitude em Kant pode então ser encontrada em sua teoria do conhecimento. De acordo com a Crítica da Razão Pura, a estrutura formal e a priori do entendimento e da sensibilidade, isto

\footnotetext{
${ }^{52}$ Lebrun, “Transgredir a finitude", p. 10.

${ }^{53}$ Cf. Vuillemin, op. cit., p. 11.

${ }^{54}$ Foucault, "Philosophie et psychologie", in DE I, p. 474.
} 
é, os conceitos e as formas puras da intuição sensível, espaço e tempo, são condição de qualquer conhecimento possível. Ora, enquanto condição de possibilidade, podemos dizer que essa estrutura formal ou transcendental do homem é aquilo mesmo que marca a finitude e o limite do seu conhecimento, pois não é possível conhecer sem conceitos, nem tampouco sem a intuição do tempo e do espaço. Como se sabe, é a não observância desse último limite ou dessa última condição que leva aos raciocínios dialéticos.

No âmbito dos raciocínios dialéticos descritos por Kant na "Dialética Transcendental", porém, parece estar as indicações de uma outra concepção de finitude que irá fazer carreira na filosofia depois de Kant. Filosofia que, em última instância, procurará realizar uma analítica da dialética transcendental; uma filosofia que não pensará mais a finitude como limite positivo de nosso conhecimento, ou seja, não a pensará mais no âmbito epistemológico e lógico, mas pensará a finitude como aquilo que diz respeito ao próprio ser do homem, uma finitude que procurará ser definida positivamente no âmbito da ontologia e da empiricidade. Ora, será justamente na passagem de uma concepção puramente transcendental da finitude para uma concepção empírica dela que se realizará, segundo Foucault, uma confusão entre o empírico e o transcendental.

Vejamos, então, de perto, como se deu essa passagem.

\section{Uma ontologia da finitude: um retorno às metafisicas pré-kantianas}

Para compreendermos o modo como a finitude que aparece em Kant ligou-se à confusão entre empírico e transcendental, interessa-nos em especial o primeiro tipo de raciocínio dialético ou sofístico descrito por Kant na Crítica da Razão Pura: os paralogismos da razão pura.

Em linhas gerais, podemos dizer que esse é o caso em que a razão entra em contradição consigo mesma quando se propõe a conhecer objetivamente aquilo que garante a unidade do Eu que percebe, sente e pensa. Para os metafísicos, esse $\mathrm{Eu}$ anterior a qualquer ato de perceber, sentir, pensar ou conhecer e que funciona como polo unificador dessas diversas atividades é a alma; para a psicologia racional, o Eu pensante. Segundo Kant, tanto a psicologia racional do eu pensante quanto a metafísica da alma operam um raciocínio falso e acabam caindo no que o filósofo chama de ilusão transcendental; tanto uma quanto outra procuram dar à unidade do eu e do pensamento, que é simplesmente uma unidade lógica e transcendental, o estatuto de um objeto que pode ser conhecido e, portanto, um objeto do qual poderíamos ter a experiência sensível ${ }^{55}$.

\footnotetext{
${ }^{55}$ Cf. Kant, Crítica da Razão Pura, p. 360 e pp. 369-70.
} 
Em poucas palavras podemos dizer que o erro da psicologia racional ou da metafísica da alma, como a de Descartes, por exemplo, estaria em conferir estatuto ontológico a algo que, para Kant, só teria um estatuto lógico; ou ainda, dar estatuto empírico a algo que só seria da ordem do transcendental ${ }^{56}$. Estamos falando aqui, portanto, de uma possível confusão entre empírico e transcendenta ${ }^{57}$. E aqui vale notar que Foucault, na introdução à Antropologia de um ponto de vista pragmático, afirma que a confusão operada pelas reflexões sobre o homem entre empírico e transcendental nasce dessa primeira confusão que Kant apontara na Crítica da Razão Pura. Confirma nosso autor: "de fato, uma deriva historicamente da outra, ou melhor, é por uma mudança de sentido da crítica kantiana à ilusão transcendental que a ilusão antropológica pode nascer"58.

É principalmente em dois textos que Foucault se detém no estudo da finitude do homem moderno: na "Introdução à Antropologia" que, como se sabe, serviu como tese complementar à tese de doutoramento, de 1961, História da loucura na Idade Clássica, e em As palavras e as coisas, de 1966.

Em ambos os textos é interessante notar que a nova figura da finitude é decorrente da torção que os saberes modernos executam na questão kantiana do transcendental. Em mais de uma passagem, Foucault procura deixar claro que apesar da retomada da temática da condição de possibilidade, o transcendental, na modernidade pós-kantiana, não tem o mesmo sentido que em Kant. Sabemos já, de acordo com o que falamos sobre o nascimento das ciências positivas como biologia, economia e filologia, que ele se confunde com o campo do empírico, mas o que exatamente significa isso do ponto de vista da reflexão filosófica?

Segundo Foucault, isso significa que o transcendental estará atrelado a um questionamento ontológico e não mais lógico ou epistemológico. Desse modo, perguntar-se pelos limites do homem ou por sua finitude não será mais perguntar-se pelas condições de possibilidade de todo conhecimento verdadeiro, mas por aquilo que faz o homem ser como é. E aqui, é a essência mesmo da crítica kantiana que parece se esvair; afinal, como esclarece Lebrun, a crítica não tem por intenção anunciar alguma verdade sobre o ser do homem, mas apenas a "sondar e testar aquilo que

\footnotetext{
${ }^{56}$ Kant, por exemplo, nota sobre esse raciocínio dialético: “a exposição lógica do pensamento em geral é erroneamente considerada uma determinação metafísica do objeto" (Kant, Crítica da Razão Pura, p. 341); ou "A unidade da consciência que serve de fundamento às categorias, é considerada uma intuição do sujeito enquanto objeto" (Idem, p. 360).

${ }^{57}$ A confusão entre empírico e transcendental pode também ser compreendida a partir do conflito entre entendimento e razão. Como esclarece Lebrun, enquanto o entendimento tem função sintetizante e depende dos dados da experiência para produzir conhecimento, a razão tende a ser totalizante, mas como não lida com os dados sensíveis, as ideias produzidas por ela não podem ser conhecidas como se fossem objetos, isto é, como se possuíssem algo empiricamente correspondente, mas somente pensadas transcendentalmente (Cf. Lebrun, Kant e o fim da metafisica, p. 90).
}

${ }^{58}$ Foucault, “Introduction à l'Anthropologie”, p. 77. 
nós acreditamos estar no início dos dados imediatos"59. A crítica, assegura Lebrun, "não nos traz uma outra verdade; ela nos ensina a pensar de outra maneira"60.

Como vimos acima, num certo sentido, aquilo que nos faz ser o que somos é a nossa empiricidade, as determinações empíricas do corpo e da vida que temos, do trabalho que realizamos e da língua que falamos. Nesse sentido, é a nossa empiricidade que nos impõe limites para sermos de determinada maneira, é ela que em nós é marca de nossa finitude. Que nova figura da finitude vemos demarcada aí? Uma finitude positiva e empírica que marca não mais os limites formais de um conhecimento possível, mas os limites concretos de uma maneira de ser.

Porém, essa nova figura da finitude não é peculiar pelo simples fato de indicar empiricamente nossos limites positivos. Vimos também que as mesmas determinações empíricas que, por um lado, dizem o que somos, por outro lado, não dizem o que somos. Afinal, o meu corpo, o meu trabalho e a minha fala são todos marcas de alguma coisa mais velha do que eu. Ou seja, este sujeito/objeto que sou, esse duplo empírico-transcendental em mim, além de ser sede dessa promíscua relação entre condicionado e condicionante, é essencialmente um ser alienado de si mesmo, um ser que é e, ao mesmo tempo, não é. Essa é pois a grande característica da finitude nos moldes do pensamento moderno: uma finitude alienada ${ }^{61}$.

Assim, ao passo que os limites concretos de nossa maneira de ser (a vida, o trabalho e a língua) nos colocam sempre na posição de estranhamento conosco mesmos, a finitude positiva e empírica do homem consiste na marca desse ser que vem sempre acompanhado daquilo que lhe é Outro; com as palavras de Foucault: “o Outro, o fraterno e gêmeo, nascido não dele, nem nele, mas ao lado e ao mesmo tempo, numa idêntica novidade, numa dualidade sem apelo"62. E na medida em que para os saberes modernos sobre o homem o empírico se repete no transcendental, essa finitude

\footnotetext{
${ }^{59}$ Lebrun, Kant e o fim da metafísica, p. 6.

${ }^{60}$ Idem, p. 5.

${ }^{61}$ Sobre isso, escreve Lebrun: "Será preciso aguardar o homem da epistémê moderna - ou melhor, 'a nova figura' que recebeu 'esse velho nome' - para que a Finitude não seja mais pensada como um território cujos limites posso traçar, mas sim entrevista como a própria sombra do homem, como uma opacidade originária que nenhum exercício da consciência de si jamais poderá dissipar. É desta 'experiência' que brota a analítica moderna da Finitude" (Lebrun, "Transgredir a finitude", p. 11).

${ }^{62}$ Foucault, As palavras e as coisas, pp. 450-1.
} 
positiva que nos apresenta o homem alienado de si mesmo não só é observada empiricamente, mas é também procurada do lado do transcendental ${ }^{63}$.

Ou seja, ser alguma coisa que me escapa não será somente a marca daquilo que sou empiricamente, mas também de minha própria condição transcendental: sou constitutivamente um ser alienado de mim mesmo. Com as palavras de Lebrun, o que se passa é que se transforma uma verdade de fato em uma verdade de razão ${ }^{64}$. E ainda com Lebrun, podemos dizer que é principalmente à fenomenologia, em especial a Merleau-Ponty, que Foucault se refere nessas páginas de As palavras e as coisas, pois é o retorno ao vivido, diz Lebrun, que "fica aprisionado num vaivém sem fim, entre a descrição e a fundação" ${ }^{65}$. É aqui, então, que se tornaria possível aquilo que Foucault chama de analítica da finitude. E o filósofo esclarece o propósito deste tipo de reflexão, em As palavras e as coisas:

mostrando que o homem é determinado, trata-se, para ela de manifestar que o fundamento dessas determinações é o ser mesmo do homem em seus limites radicais; ela deve manifestar também que os conteúdos da experiência são já suas próprias condições, que o pensamento frequenta previamente o impensado que lhes escapa e cuja reapreensão é sua tarefa de sempre; ela mostra como essa origem de que jamais o homem é contemporâneo lhe é a um tempo retirada e dada ao modo da imanência; em suma, trata-se sempre, para ela, de mostrar como o Outro, o Longínquo é também o mais Próximo e o $\mathrm{Mesmo}^{66}$.

$\mathrm{Na}$ "Introdução à Antropologia", contudo, Foucault deixa claro que é preciso recusar toda e qualquer analítica da finitude que, em última instância, busca compreender o ser do homem em sua finitude radical. O motivo? Além da confusão entre empírico e transcendental, ela opera uma ilusão; ilusão correlata à ilusão transcendental ou ilusão dogmática que se ocultava na metafísica prékantiana. E Foucault é enfático: “É por simetria e se referindo a ela como fio condutor que podemos compreender em que consiste essa ilusão antropológica. Com efeito, uma deriva historicamente da outra" ${ }^{67}$. Foucault explica essa filiação. Na verdade, a ilusão antropológica nasce a partir de um sentido novo que se dá à ilusão transcendental. Se para Kant a ilusão transcendental explicava-se a partir de um movimento natural da razão em produzir a ideia de uma unidade absoluta do sujeito, unidade, porém, que não pode ser conhecida por meio da experiência, para as analíticas da finitude

\footnotetext{
${ }^{63}$ Podemos dizer, com Deleuze, que a tentativa das analíticas da finitude é, no fím das contas, preencher o espaço vazio deixado pela descoberta de que o homem é finito e de que há nele algo que lhe escapa por meio de uma representação que nos dê essa imagem do ser alienado de si mesmo. O impensado e o não pensado do homem, o obscuro no homem, o seu abismo, é então considerado o fim do homem e o ponto originário do pensamento. O pensamento não se oporá ao impensado, como se fosse algo exterior a ele, mas se alojará no seu interior (Cf. Deleuze, "L'homme, une existence douteuse", p. 69).

${ }^{64}$ Lebrun, "Note sur la phénoménologie...", p. 44.

${ }^{65}$ Lebrun, "Transgredir a finitude, pp. 12-3.

${ }^{66}$ Foucault, As palavras e as coisa, p. 469.

${ }^{67}$ Foucault, “Introduction à l'Anthropologie”, p. 77.
} 
essa naturalidade da razão em pensar sobre o que não pode ser conhecido será interpretada como a natureza da natureza humana. Diz Foucault:

O caráter necessário da aparência transcendental foi cada vez mais interpretado não como uma estrutura da verdade, do fenômeno e da experiência, mas como um dos estigmas concretos da finitude. O que Kant designou na Crítica, de um modo bastante ambíguo, como "natural", foi esquecido como forma fundamental da relação ao objeto e recuperado como "natureza" da natureza humana [...] Esta ilusão definida agora como finitude tornava-se por excelência o refúgio da verdade: aquilo no qual ela se esconde e aquilo no que sempre se pode recuperá-la ${ }^{68}$.

Ora, será justamente essa relação com o indeterminado e desconhecido que, em Kant, porém, é da ordem do acesso possível à verdade das coisas, que será tomado pelas analíticas da finitude como núcleo da verdade do homem, como estigma concreto da finitude. A ilusão antropológica, continua Foucault, "ao invés de ser definida pelo movimento que a criticava no interior de uma reflexão sobre o conhecimento, foi referida a um nível anterior” ${ }^{\prime}$. E se a ilusão transcendental consistia numa transgressão dos limites do conhecimento, numa tendência da razão em tentar encontrar para as ideias da razão uma correspondência na intuição sensível, a ilusão antropológica, dirá Foucault, "reside numa regressão reflexiva que deve dar conta dessa transgressão". Desde então, conclui o filósofo, "o problema da finitude passou de uma interrogação

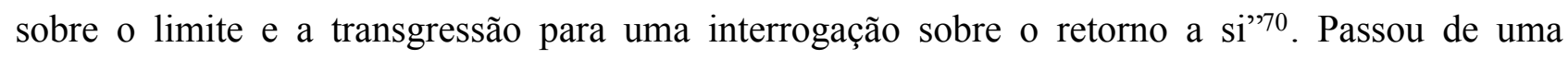
interrogação epistemológica sobre os limites do conhecimento humano para uma interrogação ontológica acerca da alienação constitutiva de nosso ser ${ }^{71}$. A partir de então, a verdade mais profunda do homem será aquela que o designa como um ser constitutivamente alienado de si mesmo, um ser que não pode deixar de percorrer o caminho que vai do Outro de si ao si Mesmo, que vai do desconhecido ao conhecimento de si mesmo como ser naturalmente finito, opaco e sombrio.

E aqui vale notar que se a estrutura cindida e alienada do ser empírico se repete no nível do transcendental, a nova interpretação da ilusão transcendental de Kant operada pelas analíticas da finitude é, na verdade, uma repetição desta. Pois se a ilusão transcendental servia como advertência para a não confusão entre o empírico e o transcendental, foi justamente isso o que não foi observado pelos novos saberes que pretenderam conhecer positiva e ontologicamente algo que transcende a

\footnotetext{
${ }^{68}$ Ibidem. Com efeito, Otfried Hoffe, em seu livro sobre Kant, comenta a dialética da razão nos temos de finitude: "a dialética passa a ser uma característica constitutiva da razão humana, o sinal de sua finitude" (Hoffe, Immanuel Kant, p. 19).

${ }^{69}$ Foucault, “Introduction à l'Anthropologie”, p. 77.

${ }^{70}$ Foucault, “Introduction à l'Anthropologie”, p. 77.

71 Cf. Hyppolite apud Vuillemin: "A crítica que Kant faz da ontologia clássica está destinada a preparar uma nova ontologia, aquela em que o ser é o sujeito que se coloca a si mesmo, um ato e não um substrato inerte. O ser é liberdade" (Vuillemin, op. cit., p. 2).
} 
experiência, a saber, o fundamento da finitude transcendental, se assim podemos dizer, do homem. Desse modo, se Foucault afirma que as analíticas da finitude começaram a partir de Kant, é importante levar a sério a ressalva de que elas não começaram com ele, pois se elas operam a confusão entre empírico e transcendental, Kant, porém, havia mostrado sua distinção ${ }^{72}$.

${ }^{72}$ Foucault, As palavras e as coisas, p. 471. 


\section{CAPÍTULO 2. KANT: ANTROPOLOGIA PRAGMÁTICA E A NOÇÃO DE USO}

Acabamos de delinear qual seria o problema do homem tal como foi tomado pelas ciências humanas e pelas analíticas da finitude: um homem ontologicamente duplo que é, a um só tempo, sujeito e objeto, empírico e transcendental, constituído e constituinte. Essa é a figura do que Foucault chama de duplo empírico-transcendental e é a figura do homem que irá caracterizar pejorativamente a maioria dos saberes sobre o homem de antropologismo e humanismo.

Nesta segunda parte, nosso intuito é compreender como a antropologia kantiana não pode ser taxada de "antropologismo", ou seja, como ela mesma, apesar de se constituir como uma reflexão sobre o homem, não cai nas aporias da confusão entre empírico e transcendental, indicadas por Foucault.

Como veremos, a antropologia pragmática antes de ser um questionamento sobre a essência do ser do homem, é uma investigação sobre a maneira como se dá, no homem, a interação de fato daquilo que nele pode ser conhecido de duas maneiras distintas: o transcendental e o empírico, a liberdade e a natureza, a passividade e a síntese. Ao se questionar sobre a facticidade da relação entre empírico e transcendental a antropologia pragmática, não terá pretensões fundacionistas, isto é, não pretenderá conhecer qual é o fundamento do homem, nem o fundamento ontológico, nem o epistemológico, nem o psicológico, mas visa conhecer as práticas ou os usos que o homem realiza na interação entre aquilo que a natureza fez dele e aquilo que ele pode (teoricamente) e deve (praticamente) fazer de si mesmo.

Que Kant tenha mantido a distinção entre empírico e transcendental na Crítica da razão Pura parece inquestionável; sabemos, pois, que este é desde o início o seu propósito e sua advertência, principalmente na "Dialética Transcendental". Porém, chegar às mesmas conclusões no que se refere à Antropologia é mais delicado. Pois, afinal, como seria possível manter aí a distinção entre o empírico e o transcendental se a antropologia pragmática, como diz o próprio Foucault, não deixa de ser uma espécie de repetição da Crítica? Como conciliar a tese de que na antropologia kantiana não há confusão entre empírico e transcendental se na Antropologia, conforme Foucault afirma, transcendental e empírico são dados numa continuidade indivisível? ${ }^{73}$

Trata-se, então, de mostrar em que medida a Antropologia pragmática é um tipo de investigação empírica que mantém relações com o questionamento transcendental, sem, porém,

\footnotetext{
73 "O que a Crítica distinguia como possível na ordem das condições (Vermögen) e o real na ordem do constituído (Escheinung) é dado pela Antropologia numa continuidade indivizível" (Foucault, "Introduction à l'Anthropologie”, p. 44).
} 
configurar-se como uma reflexão que confunde um e outro domínio. Trata-se de mostrar, portanto, em que sentido a antropologia pragmática de Kant é uma "boa" antropologia que não dorme no sono antropológico. Como veremos, isso se deve ao fato da antropologia kantiana estar situada no domínio das questões relativas à maneira como o homem habita o mundo, e não no domínio dos problemas referentes à finitude do homem; sua indagação não será tanto acerca da essência do homem, mas do homem enquanto cidadão do mundo; sua preocupação não será, pois, responder à pergunta “O que é o Homem?” (a famosa quarta questão anunciada por Kant na Lógica ${ }^{74}$ ), mas indicar as possibilidades que o homem tem de agir livremente estando situado num mundo que é mais antigo que ele, ou seja, as possibilidades que o homem tem de fazer uso desse mundo. Insiste Foucault: "a Antropologia tal como a conhecemos em nenhum momento se dá como resposta à quarta questão"75.

\section{Empírico e transcendental na Antropologia de um ponto de vista pragmático}

Segundo Foucault, o espaço da antropologia de Kant não é nem aquele de uma investigação puramente transcendental, como é o caso de uma investigação crítica, nem aquele de uma investigação estritamente empírica, como seria o caso de uma psicologia empírica ou de uma fisiologia. Diz o filósofo acerca do domínio da antropologia pragmática:

E o domínio da antropologia, longe de ser o do mecanismo da natureza e das determinações extrínsecas (ela seria então uma "fisiologia") é inteiramente habitado pela presença surda, solta e por vezes desviada de uma liberdade que se exerce no campo da passividade originária. Em suma, vemos esboçar-se um domínio próprio da antropologia, aquele em que a unidade concreta das sínteses e da passividade, do afetado e do constituinte dá-se como fenômeno na forma do tempo ${ }^{76}$.

Ora, a partir dessa citação, como não se perguntar pela diferença entre a antropologia kantiana e suas herdeiras infiéis, se ela mesma coloca a questão de nosso ser empírico ao lado do questionamento transcendental? O domínio das analíticas da finitude não era justamente, como vimos, esse da união entre empírico e transcendental?

A fim de marcar a distância entre a antropologia kantiana e suas sucessoras que dormem no sono antropológico, é preciso examinar, então, em que sentido ela nos apresenta o transcendental e o empírico numa continuidade indivisível e em que sentido tal continuidade não coincide com a confusão entre empírico e transcendental.

\footnotetext{
${ }^{74}$ Essa questão se soma às outras três colocadas por Kant na "Metodologia transcendental": que posso saber?, que devo fazer?, que é permitido esperar?. Na verdade, a questão, "O que é o homem?", segundo Foucault, retoma e envolve todas as outras questões (Cf. Foucault, "Introduction à l'Anthropologie”, p. 46).

${ }^{75}$ Foucault, "Introduction à l'Anthropologie”, p. 47.

${ }^{76}$ Foucault, Gênese e estrutura na Antropologia de Kant, p. 33.
} 
Aproximar a antropologia de Kant das antropologias ou analíticas da finitude que são, aos olhos de Foucault, uma falsa antropologia, seria mesmo um grande equívoco. Justifica o filósofo:

Haveria uma falsa antropologia - e a conhecemos demasiado bem: é aquela que tentaria deslocar em direção a um começo, em direção a um arcaísmo de fato ou de direito as estruturas do a priori. A Antropologia de Kant nos dá uma outra lição: repetir o a priori da Crítica no originário, isto é, em uma dimensão verdadeiramente temporal ${ }^{77}$.

Comecemos, assim, por compreender essa dimensão do originário que não pode se confundir com aquilo que é "realmente primitivo", tal como pretendem as analíticas da finitude, mas deve ser entendido como o "verdadeiramente temporal".

Ao discorrer sobre os elementos da Crítica presentes na Antropologia, Foucault sugere que a segunda seria como uma espécie de negativo ou de inversão da primeira ${ }^{78}$. Isso seria observável: a) nas figuras da síntese e do dado; b) no que diz respeito à divisão das faculdades e suas possíveis falhas; c) no que tange à ordem das partes do próprio texto (parte sobre elementos e parte sobre método). Interessa-nos aqui o primeiro ponto. Diz Foucault:

[...] a relação do dado e do a priori assume na Antropologia uma estrutura inversa daquela que foi dada pela Crítica. O a priori, na ordem do conhecimento, torna-se, na ordem da existência concreta, um originário que não é cronologicamente primeiro, mas que desde que aparece na sucessão nas figuras da síntese, se revela como um já aí; por outro lado, o que é o dado puro na ordem do conhecimento aparece, na reflexão sobre a existência concreta, com uma opacidade que lhe confere a profundidade do já operado ${ }^{79}$.

Por um lado, o originário não se confunde com o transcendental já que é da ordem do temporal; por outro lado, o originário também não se reduz ao domínio da multiplicidade empírica, uma vez que aparece na figura da síntese. De maneira análoga, o dado empírico, que numa investigação crítica acerca do conhecimento possível aparece como multiplicidade e dispersão, na Antropologia aparece como um “já operado”, isto é, como um “já sintetizado”. Nem síntese pura do transcendental, nem multiplicidade dispersa do empírico. O originário, ao que tudo indica, é a efetividade da relação entre empírico e transcendental; é, pois, a região da experiência concreta; a região em que as condições de possibilidade transcendentais e empíricas, lógicas e ontológicas de uma experiência possível em geral já foram cumpridas e já possibilitaram a experiência que agora existe de fato.

Foucault parece apontar aqui para uma banalidade: o domínio do originário que é por excelência a região da antropologia pragmática é aquele onde as coisas acontecem de fato, onde a experiência aparece em sua efetividade concreta. E o que seria uma experiência enquanto

\footnotetext{
${ }^{77}$ Foucault, “Introduction à l'Anthropologie”, p. 58.

${ }^{78}$ Idem, p. 41.

${ }^{79}$ Idem, p. 42.
} 
efetividade concreta? Uma experiência que existe de fato e que cumpriu as duas condições necessárias para existir: foi realizada por um sujeito que garantiu sua unidade sintética da experiência (o sujeito puro agente da síntese) e foi experiência de uma multiplicidade empírica que deu o conteúdo da experiência.

Importantíssimo aqui é notar que o que está em questão é a ideia de que a distinção entre o nível transcendental e empírico da experiência é apenas uma distinção metodológica, que interessa apenas do ponto de vista do conhecimento, mas que não existe de fato no homem. Do mesmo modo que só existe de fato conhecimento que seja a união entre objetos empíricos a serem conhecidos e uma certa maneira subjetiva de conhecê-los, podemos dizer que o próprio homem só existe de fato como unidade concreta entre multiplicidade e síntese, passividade e atividade, determinação e liberdade. Não existe de fato concretamente um sujeito puro da síntese, de um lado, e a multiplicidade dos dados empíricos esperando serem sintetizados, de outro. Tal distinção só aparece quando decidimos fazer uma investigação crítica do mundo; fora dessa perspectiva um e outro domínio, o da lógica e o da ontologia, são inseparáveis. Sendo assim, o domínio do originário não é nem objeto de uma investigação puramente formal e lógica, como seria o caso da empreitada crítica, nem objeto de uma investigação absolutamente empírica. Desse modo, se a Antropologia toma o "eu" como objeto a ser conhecido, vale ressaltar que esse "eu" não deve ser confundido nem com o "eu penso" apreendido pela apercepção pura (consciência de si), nem com o "eu sou" apreendido pelo sentido interno (conhecimento de si). É o que afirma Foucault, ainda no contexto da investigação sobre o domínio da Antropologia:

região na qual a observação de si não atinge nem um sujeito em si, nem o Eu [Je] puro da síntese, mas
um eu [moi] que é objeto, e presente somente enquanto verdade fenomenal. Mas este eu-objeto, dado
aos sentidos na forma do tempo, não é entretanto estrangeiro ao sujeito determinante, já que ele não é
outra coisa, no fim das contas, que o sujeito tal como é afetado por si mesmo ${ }^{80}$.

E aqui vale retomar a diferença entre a boa e a má antropologia. Vimos acima que a boa antropologia, a antropologia pragmática de Kant, é aquela que repete o a priori da Crítica numa "dimensão verdadeiramente temporal" e não aquela que procura conhecer as estruturas a priori enquanto começo ou arcaico fora do tempo. Com outras palavras, poderíamos dizer que a boa antropologia é aquela que é capaz de manter, no nível do originário, a distinção lógica ou metodológica entre transcendental e empírico, e não aquela que quer fazer valer o formal como fundamental ou como fundamento ontológico do empírico. É, pois, justamente quando se quer fazer valer o a priori da Crítica como fundamental que se cai na confusão das analíticas da finitude ${ }^{81}$.

\footnotetext{
${ }^{80}$ Foucault, "Introduction à l'Anthropologie", pp.23-4.

${ }^{81}$ Cf. Foucault, “Introduction à l'Anthropologie”, pp. 76 e sgg.
} 
Notemos, portanto, que há ao menos três possibilidades diferentes de tratar a questão do transcendental: 1) investigá-lo como condição a priori de todo conhecimento possível, tal como faz a Crítica; 2) tomá-lo no nível da experiência concreta, não como aquilo que a precede ontologicamente, mas como aquilo que desde sempre esteve presente logicamente, um "déjà là", tal como faz a Antropologia; 3) tomá-lo em sua unidade com o empírico na dimensão da experiência concreta (ou do vivido), e tratá-lo, não como condição lógica da experiência, mas como fundamento ontológico desta, tal como faz as analíticas da finitude.

Ora, dizer que a Antropologia em sua observação empírica sobre a experiência concreta mantém a distinção lógica entre transcendental e empírico significa dizer que ela não incorre nem no erro da ilusão transcendental, nem no erro da ilusão antropológica. E isso por uma simples razão: a Antropologia de um ponto de vista pragmático, ao se restringir a uma observação empírica do homem, respeita os limites de nossa capacidade de conhecimento. Não procura descrever aquilo que está fora do alcance da experiência empírica (o estatuto ontológico de nossa finitude), mas, ao contrário, descreve aquilo mesmo que é fruto da observação empírica: aquilo que os homens fazem realmente e a maneira como realmente se comportam, a maneira como "possuem o mundo" 82 .

Diz Foucault: "Coletânea de observações empíricas, a Antropologia não tem contato com uma reflexão sobre as condições da experiência" ${ }^{" 3}$. Mas aqui é preciso atenção. Não é porque a antropologia pragmática se limita a uma descrição daquilo que é observado empiricamente no homem que ela se confunde com uma ciência empírica. Já no prefácio, Kant alerta para a distinção entre uma antropologia do ponto de vista pragmático e uma do ponto de vista físiológico:

Uma doutrina do conhecimento do ser humano sistematicamente composta (antropologia) pode ser tal
do ponto de vista fisiológico ou pragmático. O conhecimento fisiológico do ser humano trata de
investigar o que a natureza faz do homem; o pragmático, o que ele faz de si mesmo, ou pode e deve
fazer como ser que age livremente ${ }^{84}$.

Central aqui é ressaltar o caráter pragmático da antropologia kantiana. Não se trata, para o filósofo alemão, de pensar o homem em sua empiricidade ou passividade de um ser determinado pela natureza, mas de pensá-lo como agente livre que age sobre esta natureza. Mas não nos enganemos mais uma vez! Já sabemos que o homem que a antropologia pragmática quer descrever também não pode coincidir com o sujeito puro de liberdade; se assim fosse ela se confundiria com uma empreitada crítica. O sujeito ativo e livre que interessa conhecer não é um sujeito puro e transcendental, pensado fora do tempo como condição de possibilidade para toda e qualquer ação

\footnotetext{
${ }^{82}$ Cf. Kant, Antropologia de um ponto de vista pragmático, p. 23.

${ }^{83}$ Foucault, “Introduction à l'Anthropologie”, p. 41.

${ }^{84}$ Kant, Antropologia..., p. 21.
} 
livre, mas um sujeito que age livremente de fato sobre si mesmo. O acento, portanto, recai novamente sobre a efetividade e não sobre a possibilidade da ação livre, sobre o seu uso empírico e não sobre seu princípio transcendental a priori. Enfim, numa antropologia pragmática encontramos a descrição empírica acerca da maneira como os homens de fato agem sobre suas determinações naturais, ou seja, como de fato agem sobre si mesmos, como realmente são afetados por si mesmos.

Um exemplo que nos esclarece sobre a especificidade do domínio da antropologia pragmática em relação a uma antropologia fisiológica encontramos na primeira parte da Antropologia, intitulada "Didática antropológica (Da maneira de conhecer tanto o interior quanto o exterior do ser humano)", no primeiro livro, sobre a faculdade de conhecer, $\S 5$ - "Das representações que temos sem sermos conscientes".

Diz Kant: "Se estou consciente de estar vendo, distante de mim, um ser humano num prado, mesmo não estando consciente de ver-lhe os olhos, nariz, boca etc, concluo de fato apenas que essa coisa é um ser humano" 85 . Ora, esse é o caso de representações que realizamos, mesmo sem estarmos conscientes delas. Afinal, temos uma representação de um homem com olho, nariz e boca, mesmo sem termos consciência da representação de seu olho, nariz e boca. Com frequência, diz Kant, somos pegos por certas representações inconscientes, chamadas por ele de obscuras, das quais não conseguimos nos livrar. Um outro exemplo: "Estabelecer se o próprio jazigo deve ficar num jardim ou à sombra de uma árvore, no campo ou em terreno seco, é com frequência uma questão importante para um moribundo" $"$. Por mais que o indivíduo saiba que não irá desfrutar da vista de seu jazigo, nem que não deve se preocupar se este será úmido ou não, mesmo assim, não consegue se livrar de tais pensamentos: as representações não desaparecem, "mesmo que o entendimento as ilumine".

Esses dois casos, da representação de um homem distante e das representações infundadas de um moribundo, são exemplos de representação que ocorrem ao homem sem que ele tenha consciência delas e sem que possa controlá-las. Nos dois casos, portanto, o homem mostra-se passivo ao jogo das sensações e das representações. Esses exemplos, assim, explica Kant, pertencem antes a uma teoria das representações dada por uma antropologia fisiológica e não exemplos de uma antropologia pragmática. Mas, por quê? Porque só deixam perceber o homem em sua parte passiva. E por mais que nos dois casos haja a presença de um sujeito ativo da síntese, um sujeito que, mesmo inconscientemente, foi responsável pela produção de uma representação, não se pode observar em nenhum dos casos o homem no domínio da liberdade. É, pois, a liberdade o

\footnotetext{
${ }^{85}$ Kant, Antropologia..., p. 35.

${ }^{86}$ Idem, p. 36.
} 
elemento determinante de uma antropologia pragmática. Lembremos a citação de Foucault retomada acima sobre a região da Antropologia:

[...] longe do domínio da Antropologia ser aquele do mecanismo da natureza e das determinações extrínsecas (ela seria então uma 'fisiologia') ela é completamente habitada pela presença surda, desenrolada e frequentemente desviada, de uma liberdade que se exerce no campo da passividade originária. ${ }^{87}$

Citação, por sinal, absolutamente em consonância com a ideia de que o conhecimento fisiológico investiga o que a natureza faz do homem, e o pragmático, o que ele faz de si mesmo, ou pode e deve fazer como ser que age livremente.

Voltemos, então, ao $\S 5$ da Antropologia e vejamos um outro exemplo de representação inconsciente que envolva a liberdade humana e que, portanto, pertença ao campo da antropologia pragmática. É o caso dos místicos que, deliberadamente, fazem uso de certas representações obscuras a fim de tornar sua sabedoria mais atraente. Pode-se, por exemplo, fazer um objeto parecer maior do que é se ele for visto no meio de uma névoa. Nessas condições, o objeto é representado sem que se tenha total clareza dele, e além de parecer maior, diz Kant, a obscuridade da representação faz com que o objeto seja visto como mais penetrante e profundo. Esse seria, pois, um exemplo de como se pode usar com liberdade certas representações não conscientes ${ }^{88}$.

Ora, para compreendermos essa efetividade da ação livre que vemos em cena na Antropologia, talvez valesse a pena resgatarmos alguns pontos centrais da consideração kantiana acerca da natureza e da liberdade. E se páginas atrás resgatamos a vizinhança existente entre os paralogismos da razão e a ilusão antropológica, poderíamos retomar agora aquilo que Kant nos fala sobre as antinomias da razão, que constituem a segunda espécie de raciocínio dialético estudado na "Dialética Transcendental".

A relação entre natureza e liberdade: antinomia da razão e uso

De acordo com Kant, a segunda espécie de raciocínio dialético, ao qual tendemos naturalmente, é aquele que busca por uma "unidade incondicionada das condições objetivas no fenômeno"89; com outras palavras, aquele que busca por uma totalidade absoluta da série das condições de um fenômeno dado em geral. Interessa-nos aqui em particular a terceira antinomia que

\footnotetext{
87 Foucault, Gênese e estrutura na Antropologia de Kant, p. 33.

${ }^{88}$ Cf. Kant, Antropologia..., p. 37.

${ }^{89}$ Kant, Crítica da Razão Pura, p. 379.
} 
se refere ao conflito que existe entre duas maneiras distintas de pensar a relação entre natureza e liberdade.

Por um lado, para o pensamento de tipo dogmático, dada a série causal observada na natureza, é preciso admitir outro tipo de causa que esteja fora desta série. Com as palavras de Kant: "temos de admitir uma causalidade pela qual algo acontece, sem que a causa seja determinada por uma outra causa anterior, segundo leis necessárias, isto é, uma espontaneidade absoluta das causas" 90 . Por outro lado, há a tese ou anti-tese empirista que defende o seguinte: "A liberdade transcendental é contrária à lei de causalidade, por conseguinte, um encadeamento de estados sucessivos de causas eficientes, segundo o qual não é possível uma unidade da experiência [...] é um vazio ser de razão" $"$.

De modo geral, podemos dizer que, segundo a tese dogmática, existe uma espontaneidade absoluta, isto é, uma liberdade absoluta, que está fora das determinações causais da natureza; a antitese empirista, porém, afirma que não há liberdade, pois tudo no mundo pertence à série causal da natureza, isto é, é determinado pelas leis da natureza.

Ora, diz Kant, é legítimo supor que há uma causa livre que seja a causa da causalidade que observamos na natureza. E aqui o filósofo agrada aos dogmáticos que tendem a afirmar a mesma coisa. Porém, e aqui vemos sua defesa empirista, por mais que exista de fato uma causa livre, se ela é livre e incondicionada, ela não pode ser conhecida uma vez que não pode ser intuída por nossa sensibilidade. Para Kant, portanto, é preciso ter claro que a liberdade é uma ideia da razão, uma ideia transcendental, que não remete a nada que possa ser intuído pela experiência sensível; ou seja, a liberdade é uma ideia sobre a qual podemos pensar e supor a existência, mas não alguma coisa que podemos conhecer verdadeira a objetivamente. Segundo o filósofo, é somente fazendo a distinção entre uma liberdade que só é da ordem do pensamento e a causalidade da natureza que é da ordem do conhecimento empírico que o conflito, aparentemente insolúvel, entre dogmáticos e empiristas, entre causalidade da natureza e liberdade, pode ser desfeito ${ }^{92}$. É só nesse contexto que é possível pensar sem conflito que natureza e liberdade convivem lado a lado.

Kant diferencia, portanto, dois tipos de causalidade que, por sua vez, devem ser conhecidos de duas maneiras diferentes: uma segundo a natureza, que seria uma causalidade empírica, e outra

\footnotetext{
${ }^{90}$ Kant, Crítica da Razão Pura, p. 408.

${ }^{91}$ Idem, p. 407.

92 Diz Kant: “Assim desaparece a antinomia da razão pura nas suas ideias cosmológicas, desde que se mostrou que se é apenas dialética e é o conflito de uma aparência de se ter aplicado a ideia de totalidade absoluta, válida unicamente como condição da coisa em si, a fenômenos, que só existem na representação, e quando constituem uma série, na regressão sucessiva, mas que não existem de qualquer outro modo" (Idem, p. 446).
} 
segundo a liberdade, ou segundo a razão, que seria uma causalidade inteligível. A primeira, com as palavras do filósofo, "é, no mundo sensível, a ligação de um estado com o precedente, em que se segue ao outro segundo uma regra"93. A segunda é "uma faculdade de iniciar por si um estado cuja causalidade não esteja, por sua vez, subordinada, segundo a lei natural, a outra coisa que a determine quanto ao tempo"94.

É possível, então, de acordo com Kant, pensar, sem contradição, que o homem é livre, mas também determinado. Tudo depende do ponto de vista do qual se fala do homem: o ponto de vista crítico ou transcendental ou o ponto de vista fisiológico ou empírico. Da perspectiva transcendental, pode-se dizer que o homem é capaz de postular suas próprias leis, que são as máximas da razão, que se expressam como dever e que possibilitam ao homem ser ativo e agir livremente, isto é, sem a influência das determinações sensíveis ${ }^{95}$. Do ponto de vista empírico ou fisiológico, porém, o homem não é considerado como princípio inteligível, racional e livre, mas como fenômeno inserido na natureza, como ser empírico determinado pelas leis da natureza e por aquilo que é da ordem do sensível.

Mas, se é assim, se só é possível pensar sem contradição sobre a natureza e a liberdade se diferenciamos a crítica da fisiologia, diferenciando, portanto, o homem como pura atividade e o homem como pura passividade, o que dizer sobre a relação entre liberdade e determinação, ou liberdade e natureza, no campo da antropologia pragmática?

Ora, dizíamos acima que, segundo Foucault, a região da antropologia pragmática é justamente aquela onde se dá a interação entre o sujeito enquanto agente livre e o sujeito passivo determinado pela natureza; aquela em que o homem não é nem sujeito puro de liberdade, nem homo natura, mas aquela em que o homem é aquilo "que ele faz de si mesmo, ou pode e deve fazer como ser que age livremente". Mas será, então, que a antropologia pragmática nos põe novamente diante de uma antinomia da razão? Seguramente não, pois mesmo que ela nos fale do homem enquanto um ser que é, a um só tempo, livre e determinado, ela não chega a confundir um e outro domínio: o da liberdade da razão e o da determinação sensível. A antropologia pragmática não nos coloca diante de um paradoxo. Ela não exige de nós que optemos entre uma tese dogmática que nos mostra um sujeito absolutamente livre ou uma tese empirista que defende um sujeito absolutamente determinado pela natureza. A antropologia pragmática nos coloca, antes, diante do homem tal como

\footnotetext{
${ }^{93}$ Kant, Crítica da Razão Pura, p. 462.

${ }^{94}$ Idem, p. 463.

${ }^{95}$ Cf. Kant, Crítica da Razão Pura, p. 463.
} 
ele é de fato: tanto livre quanto determinado. Seu intuito não é o de nos fazer decidir se o homem é livre ou determinado e como seria possível conhecer a liberdade e a determinação, mas o de apresentar o homem pondo em prática sua liberdade no campo de suas determinações. Ou seja, seu intuito não é nem de ser uma crítica, nem uma fisiologia, mas um tipo de investigação que nos apresenta o homem agindo livremente sobre si mesmo. O domínio específico da antropologia pragmática, portanto, é esse domínio pragmático (e não crítico ou fisiológico) em que o homem usa sua liberdade sobre suas determinações.

Esse caráter pragmático da antropologia kantiana nos leva, assim, a um tema muito caro a Foucault, a saber: o tema do uso (usage) que traduz do alemão Gebrauch. A noção de uso é justamente aquela que irá apontar para a relação concreta, e não contraditória, entre empírico e transcendental no domínio do originário, pois, nesse domínio, é no uso que natureza e liberdade estão intimamente intrincadas ou é no uso que ambas aparecem numa continuidade indivisíve ${ }^{96}$. Desse modo, se, como vimos, Foucault nos alerta que a ação livre que a Antropologia procura descrever não coincide com a descrição de um sujeito puro de liberdade, isto se dá justamente porque ela se interessa pela maneira como o homem faz um uso livre de suas faculdades mentais, como age com liberdade em confronto com as determinações que a natureza lhe impõe.

Foucault nos fala em exercício cotidiano e em jogo a fim de explicar a ideia de uso. O filósofo nos lembra que para Kant o homem é um "jogo da natureza"97. Ou seja, é jogado pela natureza, no sentido que ela o determina: determina sua natureza e determina suas ações. Porém, insiste Foucault, o homem não é somente um jogo da natureza, mas ele mesmo, enquanto participa desse jogo, pode jogar com ela. Isso porque ele tem liberdade. E aqui voltamos à noção de uso, pois dizer que o homem joga com a natureza é dizer que ele a utiliza, que age sobre ela. Nesse sentido, diz Foucault, a Antropologia não é um livro de teoria, mas um livro sobre o exercício cotidiano, uma "análise da maneira como o homem adquire o mundo (seu uso, não seu conhecimento), quer dizer, como ele pode se instalar nele, e entrar no jogo"98.

É quase com as mesmas palavras que Kant nota a diferença entre conhecer o mundo e conhecer a maneira como o homem possui o mundo. Com o primeiro tipo de conhecimento, diz Kant, "o indivíduo só entende o jogo a que assistiu”, com o segundo, como se tomou parte dele ${ }^{99}$.

O exemplo dado anteriormente sobre as representações inconscientes ilustra essa diferença.

\footnotetext{
${ }^{96}$ Cf. Foucault, "Introduction à l'Anthripologie”, pp. 31-sgg.

${ }^{97}$ Cf. Kant, Antropologia..., p. 22.

${ }^{98}$ Foucault, “Introduction à l'Anthropologie”, p. 33.

${ }^{99}$ Kant, Antropologia..., p. 22.
} 
Uma coisa é investigar as representações inconscientes da perspectiva de uma antropologia fisiológica; nesse caso só se constata a passividade humana e a maneira como nossas faculdades mentais, nossa natureza, podem jogar conosco. Outra coisa, porém, é observar como o homem faz uso deliberado dessas faculdades, isto é, como podemos jogar com nossas representações. É o caso do místico ou mesmo dos filósofos que se utilizam de representações obscuras a fim de tornarem sua sabedoria mais atraente.

A memória é outro exemplo que esclarece o objeto da antropologia pragmática. Uma coisa, por exemplo, é conhecer teoricamente a memória a partir de suas causas naturais tal como faria uma investigação fisiológica; outra coisa é procurar conhecer as maneiras com que um indivíduo utiliza, com liberdade, sua memória, tal como faz uma antropologia pragmática. Com o primeiro tipo de conhecimento, diz Kant, nada se ganha; com o segundo, porém, se conhecem as maneiras de ampliar e de tornar mais ágil a memória ${ }^{100}$.

O lugar central da liberdade na antropologia pragmática deve-se, então, ao fato que é graças a ela que podemos dominar nossa própria natureza garantindo, assim, um bom uso de nossas faculdades. Sim, porque é preciso se esforçar para garantir um bom uso delas, pois naturalmente elas tendem ao desvio quando se efetivam. Pelo menos é assim que Foucault lê Kant.

Como sabemos, o campo de experiência descrito pela Antroplogia é o campo da experiência efetiva que se desenrola no tempo. O tempo, entretanto, é um elemento que ameça as possibilidades de nossas faculdades, tal como a conhecemeos a priori. "Na região antropológica não há síntese que não esteja ameaçada"101, enfatiza Foucault. Apesar de a Antropologia seguir a divisão das faculdades que a Crítica também admite, o domínio que ela privilegia, diz Foucault, não é aquele em que faculdades manifestam o que têm de positivo, mas, ao contrário, aquele em que manifestam sua fragilidade, seus desvios ${ }^{102}$. É só no mundo do conhecimento transcendental, a priori e atemporal, o da Crítica, que as faculdades aparecem de maneira perfeita; quando efetivadas no tempo, as sínteses realizadas pelas faculdades da alma estão dispersas e correm o risco de nos levar ao erro.

Com efeito, toda a primeira parte da Antropologia de um ponto de vista pragmático é marcada pelos desvios das faculdades da alma (faculdade de conhecer, sentimento de prazer e

\footnotetext{
100 Kant, Antropologia..., p. 21. Sobre o uso que podemos fazer da memória, Kant ainda cita o exemplo da tópica que é "uma divisória para conceitos gerais, denominados, lugares-comuns, que facilita a lembrança por meio da divisão em classes, como quando se repartem pelas estantes de uma biblioteca os livros com diferentes etiquetas" (Idem, p. 82).

101 Foucault, "Introduction à l'Anthropologie”, p. 43.

102 Cf. Foucault, "Introduction à l'Anthropologie", p. 43.
} 
desprazer e faculdade de desejar). No entanto, a Antropologia não é somente uma descrição negativa do desenrolar de nossas faculdades no tempo; afinal, ela se interessa também pelas situações em que a liberdade faz com que tenhamos um uso correto delas, faz com que possamos corrigir seus desvios. Nesse sentido, enfatiza Foucault, cabe à liberdade evitar o erro ${ }^{103}$. E Kant no $\S$ 8 da Antropologia confirma: "A perfeição interna do ser humano consiste nisso: ter o uso de todas as suas faculdades em seu poder, para submetê-lo ao seu livre-arbítrio"104.

É, então, de se notar, como propõe Foucault, o ritmo ternário e o caráter sistemático com que Kant descreve nossas faculdades na Antropologia. Primeiramente, ele as apresenta em suas possibilidades, retomando de certo modo as Críticas; em seguida, mostra um possível uso empírico abusivo delas; e, por fim, a liberdade entra em cena para garantir um bom uso das faculdades ${ }^{105}$. No domínio de cada faculdade da alma, poderíamos encontrar esse ritmo ternário que vai do que se pode ao que se deve fazer de si mesmo, passando por um mal uso empírico das faculdades. Foucault lembra, então, o caso da imaginação. Em primeiro lugar, ela é descrita como faculdade de intuição sem a presença do objeto que pode ser produtiva ou reprodutiva ${ }^{106}$. Quando a produção de ficções imaginárias é desgovernada e desenfreada ela pode até levar à loucura; se bem administrada pelo livre-arbítrio, contudo, a imaginação produz as invenções da arte, vivifica a mente e favorece a sociabilidade ${ }^{107}$.

Desde o início de seu comentário Foucault insiste na tese de que a Antropologia de Kant é o lugar onde o poder e o dever se cruzam; o lugar onde as possibilidades de nossas faculdades se encontram com a liberdade ${ }^{108}$. Já vimos, com efeito, que, para Kant, a antropologia pragmática consiste numa investigação acerca do que o homem pode e deve fazer de si mesmo como ser que age livremente. Sobre isso, nota, então, Foucault:

A Antropologia é, pois, por essência a investigação de um campo onde o prático e o teórico se atravessam e se recobrem inteiramente; ela repete, em um mesmo lugar, e em uma mesma linguagem, o a priori do conhecimento e o imperativo da moral $[\ldots]^{109}$.

\footnotetext{
${ }^{103}$ Foucault, "Introduction à l'Anthropologie”, p. 56.

104 Kant, Antropologia..., § 8, p. 43.

105 Foucault, "Introduction à l'Anthropologie”, pp. 44-45.

${ }^{106}$ Cf. Kant, Antropologia..., § 28, p. 66.

107 Cf. Kant, Antropologia..., § 30, § 33, § 88.

108 De acordo com o próprio Kant, é uma tautologia dizer que a Antropologia ensina o que se deve e o que se pode fazer de si memso; bastaria dizer que ela ensina o que se deve fazer, para concluir que isso é o que se pode fazer, já que a razão não ordena o impossível (Cf. Kant, Antropologia..., § 12, p. 48).
}

${ }^{109}$ Foucault, "Introduction à l'Anthropologie”, pp. 65-66. 
Mas o que exatamente significa dizer que na Antropologia o teórico e o prático, o poder e o dever aparecem lado a lado? Significa dizer que no mundo da experiência efetiva, as possibilidades de conhecimento e a ação livre são inseparáveis; que, de fato, epistemologia e ética não se separam; que a fim de garantir um bom uso empírico e efetivo, e não puro, de nossas faculdades mentais, precisamos contar com o dever moral e com a liberdade em seguir as leis da razão. Mas não é só isso. Visto que em Kant a obediência ao dever moral postulado pela razão significa agir tendo em vista a humanidade, ao colocar a liberdade (que em Kant é sempre a liberdade de agir de acordo com as leis da razão) como central para a ação do cidadão do mundo, a Antropologia de um ponto de vista pragmático deixa de ser simplesmente um livro que ensina a maneira como o homem possui o mundo e passa a ser, sobretudo, um ensinamento sobre a maneira como os homens possuem o mundo a fim de efetivar sua destinação moral: a humanidade. Não é por acaso que os usos de nossas representações, inclusive as representações ilusórias, que favorecem o convívio e a sociabilidade, são legítimas.

Assim, se a embriaguez com ópio e aguardente não é vista com bons olhos por Kant é porque neste estado os homens ficam mais calados e reclusos. Em contrapartida, a embriaguez com cerveja e vinho parece ser moralmente boa, uma vez que estimula a sociabilidade e a comunicação dos pensamentos: a ilusão de não se ter obstáculos na vida torna os homens despreocupados e, com atenção mais frouxa sobre si mesmos, eles soltam as línguas e abrem os corações ${ }^{110}$. Nas mulheres, a maquiagem é um engano, que facilmente se desfaz, e que não deve ser admitido; um vestido cuja cor se destaca vantajosamente para a vista é um tipo de engano dos sentidos que não tem como ser desfeito, uma ilusão, e que pode ser admitido. No primeiro caso, se é burlado, diz Kant, no segundo, se é seduzido. Ou seja, no primeiro caso, o engano não tem nenhuma utilidade moral, no segundo, ele favorece a sociabilidade ${ }^{111}$. Uma falsa representação de nós mesmos como bons é um engano que precisa ser elimidado. Tal aparência em nada contrubui à moralidade; ao contrário, faz com que o indivíduo não se sinta culpado e responsável pelas más ações. A pudicícia, em contrapartida, "uma autocoerção que oculta a paixão", é uma ilusão ou uma aparência moralmente permitida, uma vez que mantém o respeito entre homens e mulheres. Assim como a cortesia, "uma aparência de condescendência", que infunde amor ${ }^{112}$. Segundo Kant, quanto mais civilizado é o

\footnotetext{
${ }^{110}$ Cf. Kant, Antropologia..., § 29, p. 70 .

111 Kant aqui diferencia engano de ilusão. "A ilusão é aquele engano que permanece ainda que se saiba que o objeto suposto não é real [como a ilusão de ótica] [...]. O engano dos sentidos ocorre, porém, quando a aparência cessa imediatamente, tão logo se saiba o que se passa com o objeto.” (Kant, Antropologia..., § 13, p. 49)
}

112 Cf. Kant, Antropologia..., § 14, p. 51. 
homem, mais ator ele é: ele finge simpatia, recato e altruísmo. Mas "é muito bom que as coisas sejam assim no mundo"113, diz Kant. Esse tipo de máscara social estimula a sociabilidade, e disperta a virtude e a moralidade.

Ora, ao insistir que a antropologia pragmática investiga não só o que o homem pode, mas o que ele deve fazer sobre si mesmo, é como se Kant salvasse o sujeito dos possíveis erros e desvios aos quais ele naturalmente está submetido no mundo da experiência efetiva. Desse modo, se, no tempo, todas as sínteses correm o risco de se desviarem da verdade, isso não deve ser visto como um problema. Ao contrário. Os desvios e erros de nossas faculdades aos quais tendemos naturalmente podem mesmo ser úteis ao passo que aproximam os homens, contribuindo, assim, para sua destinação moral. É o que Kant deixa claro na seguinte passagem: “A natureza implantou sabiamente no homem a propensão a se deixar de bom grado enganar, quer para salvar a virtude, quer para conduzi-lo a ela"114.

\section{O papel vivificador das representações ilusórias}

Além da utilidade moral de algumas de nossas representações, mesmo as ilusórias e falsas, Foucault também nota, na Antropologia de um ponto de vista pragmático, a utilidade vivificadora delas. E aqui Foucault parece, sorrateiramente, introduzir uma espécie de vontade de potência como princípio central no pensamento de Kant. Estamos falando do princípio vivificador que Foucault encontra na antropologia kantiana.

A tese de que algumas de nossas representações aumentam nossa força vital mostra, segundo Foucault, a sintonia entre a Antropologia e temas pré-críticos. De acordo com nosso autor, já está presente no Ensaio sobre as raças, de 1775, a ideia de que o conhecimento não deve servir simplesmente para aumentar o saber acadêmico e teórico que temos das coisas, mas deve servir, antes, para "organizar e gerar a vida concreta"115. Do mesmo modo, a antropologia pragmática que ensina a maneira como o homem adquire o mundo pode ter utilidade para a vida concreta: ela nos ensina como vivificar a mente e todas as suas faculdades (faculdade de conhecer, de desejar, e de sentir prazer e desprazer) por meio de nossas ideias ou representações.

\footnotetext{
${ }^{113}$ Kant, Antropologia..., § 14, p. 50.

114 Kant, Antropologia..., § 14, p. 51.

115 Foucault, "Introduction à l'Anthropologie", p. 19.
} 
E aqui Foucault assinala uma diferença entre a crítica e a antropologia pragmática. Pois, se na Crítica da Razão Pura, as ideias da razão são úteis em função de seu papel regulador ${ }^{116}$, na Antropologia, as ideias têm função vivificadora. Com outras palavras: na Crítica, as ideias da razão são úteis para que o entendimento cumpra sua finalidade; na Antropologia, as ideias têm utilidade prática não só porque servem ao conhecimento, à religião e à moral, mas também na medida em que dão mobilidade e vida à mente e ao homem em geral. E seria o espírito [Geist] o princípio responsável que vivifica a mente por meio de representações. Kant confirma: "Denomina-se espírito o princípio que vivifica a mente por meio de ideias" 117.

A utilidade vivificadora das ideias pode ser notada ao longo de toda a Antropologia; ela está presente tanto na faculdade de conhecimento inferior, como a sensibilidade, quanto numa superior, como a imaginação. Kant ensina, por exemplo, que dependendo do uso que damos a certas representações sensíveis, elas podem ou não vivificar a mente. O contraste entre duas impressões sensíveis é vivificador na medida em que o contraste torna ambas mais intensas e chamativas. A contradição entre duas impressões sensíveis, contudo, não vivifica a sensibilidade, mas ao contrário, torna-a mais fraca. Ensina, então, Kant: "um terreno bem cultivado num deserto faz ressaltar a representação do primeiro pelo mero contraste"118; ao contrário, "mesas fartas e numerosos serviçais, mas com sapatos de ráfia, são coisas que não estão em contraste, mas em contradição, e

116 Cf. principalmente o apêndice da "Dialética Transcendental", seção intitulada "Do propósito final da dialética natural da razão humana". Após descrever os raciocínios dialéticos aos quais tende naturalmente a razão, Kant nos diz que essa tendência natural da razão, como tudo, tem uma finalidade e utilidade: ela faz com que o entendimento ampliese o máximo possível, permanecendo sempre de acordo consigo mesmo (Cf. Kant, Crítica da Razão Pura, p. 315). Assim, as ideias da razão que, até então, tinham sido apresentadas como conceitos problemáticos que não têm um objeto que lhes corresponda na intuição sensível, aparecem aqui naquilo que têm de mais frutífero. As ideias da razão ampliam o entendimento na medida em que estimulam o seu uso empírico, estimulam sua busca por algo que, na natureza, possa corresponder às ideias: "ao admitirmos esses seres ideais, não ampliamos propriamente o nosso conhecimento para além dos objetos da experiência possível, mas apenas a unidade empírica desta, mediante a unidade sistemática cujo esquema nos é dado pela ideia, tendo essa, por conseguinte, o valor de princípio regulativo" (Idem, $\mathrm{p}$. 553). E que essa busca não termine nunca é tanto melhor, pois a busca contínua pelo incondicionado, pela unidade, pela síntese, pela sistematicidade, na natureza, faz com que o entendimento esteja sempre de acordo consigo mesmo. Assim, se, por um lado, a ideia "obriga a considerar o encadeamento no mundo segundo princípios de unidade sistemática" e "impõe a necessidade de considerar a ordenação do mundo como se brotasse de uma razão suprema" (idem, p. 560), por outro lado, é ela que garante que o entendimento cumpra a sua função. Nesse sentido, as ideias da razão não permitem que o entendimento conheça mais, mas que seja melhor dirigido. Vale lembrar que além de serem úteis intelectualmente para a razão especulativa, encontramos ainda na Crítica da Razão Pura a tese de que as ideias são também interessantes do ponto de vista prático para a moral e para a religião. Comentando sobre o dogmatismo que procura conhecer as ideias de alma, liberdade e Deus, Kant nota: "Que o mundo tenha um começo; que o meu eu pensante seja de natureza simples e portanto incorruptível; que nas suas ações voluntárias seja simultaneamente livre e superior à compulsão da natureza; que, por fim, a ordem das coisas que constituem o mundo derive de um ser originário, donde tudo recebe a unidade e encadeamento em vista de fins, tudo isto são pedras angulares da moral e da religião" (Idem, p. 421).

${ }^{117}$ Kant, Antropologia..., § 71, p. 143. Cf. ainda § 57, p. 122: "Espírito é o princípio vivificador no ser humano".

118 Idem, p. 61. 
uma representação anula ou enfraquece a outra, porque quer unir sob um mesmo conceito aquilo que é oposto, o que é impossível"119.

No campo da imaginação, a utilidade vivificadora das representações é descrita a partir de diversos exemplos. Afinal, é principalmente a imaginação que mantém vivas as forças mentais. É o que Kant parece afirmar no $\S 57$ da Antropologia: “As forças mentais têm, no entanto, de ser harmoniosamente movidas pela imaginação, porque do contrário não se vivificariam mas se perturbariam mutuamente".

Mas não é qualquer produção da imaginação que tem papel vivificador. A produção involuntária de ficções pela imaginação chama-se fantasia ${ }^{120}$. Quando estamos dormindo, a fantasia joga conosco ao produzir os sonhos. O sonho é exemplo de uma "boa" fantasia, pois é graças a ele que não morremos enquanto dormimos; é o sonho, pois, que nos mantém vivos durante o sono ${ }^{121}$. Em estado de vigíla, entretanto, uma fantasia desregrada e desenfreada ${ }^{122}$, que joga conosco, não é benéfica para o ser humano; ela é, antes, inoportuna e pode revelar um estado doentio como a hipocondria, em que o indivíduo (o fantasista) toma as produções da imaginação (fantasia) como experiências reais ${ }^{123}$. Acordados, uma fantasia vivificadora é aquela que a imaginação produz quando se entretém com objetos sensíveis aparentemente sem significado, como a fumaça de uma chaminé, os movimentos de um riacho que corre sobre pedras ou mesmo com os sons de uma música. Essa espécie de distração da imaginação alivia o trabalho do entendimento e com isso o vivifica $^{124}$. Por fim, no âmbito das relações sociais certas ilusões produzidas pela imaginação são também úteis em função de seu caráter vivificador. De acordo com Kant, os jogos de meninos (jogo de bola, corrida, luta, brincadeira de soldado) e de adultos (xadrez, cartas, jogo de azar) mostram que todos tendem a testar e fortalecer suas forças em disputa com outros. Na imaginação, eles criam a ilusão de que a finalidade desses jogos está em ganhar a bola, a corrida, a luta, uma partida, enquanto, na realidade, a finalidade da disputa vem de uma motivação subjetiva por honra, poder e dinheiro. Mas, diferentemente do que se poderia supor, Kant não recrimina esse tipo de ilusão. Ao

\footnotetext{
${ }^{119}$ Kant, Antropologia..., p. 61.

${ }^{120}$ Idem, § 31, p. 73 .

${ }^{121}$ Cf. Kant, Antropologia..., § 31 A, p. 74.
}

122 A fantasia desregrada, diz Kant, "joga totalmente com o ser humano, e o infeliz não tem de modo algum em seu poder o curso de suas representações.” (Kant, Antropologia..., § 33, p. 80).

${ }^{123}$ Idem, $\S 50$, p. 110.

124 Cf. Kant, Antropologia..., $\S 30$, p. 72; cf. também sobre vivificação do pensamento por meio da conversa $\S 88$, p. 177: “O homem que, ao se alimentar, consome a si mesmo pensando durante a refeição solitária, perde pouco a pouco a alegria que adquire quando um companheiro de mesa lhe oferece, com suas ideias diversificadas, nova matéria de vivificação, que ele mesmo não podia pressentir". 
contrário. Segundo o filósofo, ela é natural e tem sua utilidade: ela reaviva a atividade do ser humano, fazendo com que ele não perca o sentimento da vida. Considerar os objetos da imaginação fins reais faz com que o homem, que é preguiçoso por natureza, sinta-se motivado ao trabalho e que tenha sempre muito o que fazer.

Não nos parece muito descabido aproximar o Geist kantiano da vontade de potência de Nietzsche. Ambos são um princípio que tem em vista a vida e ambos se realizam por meio de nossas ideias, representações e conhecimentos. Além disso, a centralidade que Kant dá à imaginação no que diz respeito à vivificação da mente nos faz pensar que são principalmente as representações da imaginação que são úteis à vida. E se a faculdade de imaginação parece ser a faculdade que privilegiadamente produz ilusões, já que intui sem a presença de objeto, podemos dizer que são as representações ilusórias que no mais das vezes se mostram úteis para vivificar a mente.

A ideia de que os usos que fazemos de nossas representações podem ter uma utilidade moral e vital, e não somente uma finalidade epistemológica, seguramente nos permite aproximar Kant de Nietzsche. O tema, que chama a atenção de Foucault em sua leitura da antropologia kantiana, será também um dos principais pontos comentados pelo filósofo no que diz respeito à obra de Nietzsche. Como veremos, em seu primeiro curso no Collège de France, de 1971, em grande parte dedicado e inspirado por Nietzsche, a questão de nossa relação interessada com a verdade consistirá não só o epicentro do curso, mas se colocará, a partir de então, como a grande questão norteadora da pesquisa filosófica de Foucault.

É de se notar, portanto, a fecundidade que a tese complementar, a princípio um texto marginal e sem importância, tem para compreendermos o empreendimento filosófico de nosso autor. Em primeiro lugar, ela anuncia qual seria o grande problema enfrentado pela história da filosofia desde Kant: o homem em sua finitude ou em sua natureza constitutivamente alienada de si mesmo. Em segundo lugar, o comentário da antropologia pragmática mostra de que maneira é possível falar sobre o homem sem cair nas contradições típicas das analíticas da finitude que confundem o que no homem pode ser conhecido empiricamente e o que só pode ser conhecido transcendentalmente. Mostra ainda que é possível fazer uma "boa antropologia" limitando-se ao campo da facticidade e dos usos empíricos, e não puros, que os homens fazem de si mesmos, de suas faculdades mentais, de suas representações, de suas ideias. Por fim, em seu comentário sobre a antropologia kantiana, Foucault ainda ressalta que o caráter utilitário de nossa relação com a verdade ultrapassa o campo epistemológico. 
A nosso ver, toda a obra de Foucault posterior à tese complementar pode, então, ser lida como um desenvolvimento e um desdobramento desses três temas que nosso autor encontra na antropologia kantiana. Vimos já que As palavras e as coisas, de 1966, podem ser compreendidas como um livro que investiga o problema moderno do homem e que procura compreender sua aparição a partir da torção que o pensamento posterior a Kant realizou na questão da ilusão transcendental. Em seu livro de método, A arqueologia do saber, de 1969, não é de se estranhar que a superação das analíticas da finitude (das "más antropologias" que buscam fundar e ontologizar a finitude humana) é proposta por meio de uma análise do discurso que não deixa de ser uma pesquisa sobre os usos e sobre a facticidade, atualizando, desse modo, o segundo aspecto da antropologia kantiana destacada por nosso autor. Finalmente, no que diz respeito ao último ponto ressaltado na "Introduction à l'Anthropologie", o de que nossa relação com a verdade tem um interesse que vai além do campo epistemológico, será retomado por Foucault sob forte influência nietzschiana com o tema da relação entre saber e poder. Vejamos, então, por ora, de que maneira podemos compreender a arqueologia foucaultiana como uma análise dos usos e deixemos para a segunda parte da tese a investigação do modo como Foucault utiliza Nietzsche, a fim de propor uma filosofia que reflita sobre nossa relação interessada com a verdade. 


\section{CAPÍTULO 3. FOUCAULT: A ARQUEOLOGIA ENQUANTO ANÁLISE DOS USOS DA LINGUAGEM}

A intenção desse capítulo é retomar o livro de Foucault, A arqueologia do saber, de 1969, a fim de mostrar algumas proximidades entre a antropologia pragmática kantiana e a arqueologia foucaultiana. Trata-se de mostrar, em linhas gerais, que Foucault também define sua empreitada filosófica como anti-humanista e antiantropológica, que está disposto a contornar a questão do homem e que, por fim, procura fazer tal recusa por meio de uma reflexão que se volta para o domínio da facticidade da linguagem, de suas práticas e seus usos. A aproximação entre a arqueologia de Foucault e a filosofia pragmática de Kant nos permitirá compreender melhor o método inicial de nosso filósofo, assim como perceber que desde seus primeiros escritos a questão da prática e dos usos é central em sua pesquisa a fim de contornar uma filosofia humanista e antropológica do sujeito. O caráter pragmático da filosofia de Foucault nos servirá de fio condutor para compreendermos o conjunto da obra foucaultiana, para compreendermos que temas que aparecem explicitamente nos últimos livros (lembremos aqui ao menos do título de seu penúltimo livro, $O$ uso dos prazeres) já estavam anunciados desde os escritos da década de 60 no interior da discussão sobre o discurso. Com isso, numa perspectiva mais geral, podemos dizer que nosso trabalho aponta para a ideia, defendida também recentemente por Diogo Sardinha ${ }^{125}$, de que mais do que percurso filosófico é possível atribuir a Foucault um corpus filosófico. E, a nosso ver, a unidade desse corpus pode ser encontrada justamente no aspecto pragmático da empreitada.

Faremos, num primeiro momento, uma apresentação breve do livro A arqueologia do saber para ver como Foucault procura definir seu projeto como anti-humanista ou anti-antropologista. Depois, procuraremos compreender mais de perto a noção de discurso e de enunciado a fim de verificar de que modo uma arqueologia do discurso pode ser entendida como uma reflexão pragmática sobre os usos da linguagem e quais os limites desse método diante de uma empreitada antropológica mais geral que visa compreender os interesses que estão por trás desses usos.

\section{O projeto anti-humanista de A arqueologia do saber}

$A$ arqueologia do saber é uma reflexão retrospectiva que Foucault faz sobre seu próprio método utilizado nos trabalhos até então publicados: História da loucura (1961), O nascimento da

\footnotetext{
125 Sardinha, Ordre et Temp dans la Philosophie de Foucault.
} 
clínica (1963) e As palavras e as coisas (1966). E vale notar que o termo arqueologia não aparece pela primeira vez na obra de 69. Já no primeiro prefácio de História da loucura Foucault sugere a metáfora arqueológica para caracterizar o seu método; e mais tarde, nos livros de 63 e 66, o termo aparece no subtítulo das obras. O nascimento da clínica tem como subtítulo "uma arqueologia sobre o olhar médico" e As palavras e as coisas, "uma arqueologia das ciências humanas".

Mas não nos interessa aqui fazer a gênese desse termo, nem tampouco investigar se ele teria vindo de inspirações kantianas, freudianas, husserlianas ou mesmo dumezilianas ${ }^{126}$. Limitemo-nos, pois, ao sentido que esse termo parece ter nesse livro sobre o método.

Em primeiro lugar, é interessante notar que a noção de arqueológico nos remete a uma ideia de espaço, de disposição espacial. Que pensemos na ciência arqueológica clássica: ela diz respeito a diversas estratificações espaciais. E esse caráter de espacialidade no interior do método de Foucault talvez se explique se compreendermos minimamente o contexto dentro do qual foi elaborado.

Assim como em As palavras e as coisas, Foucault inicia o livro de 69 situando o cenário intelectual de sua época. Seguramente o estruturalismo terá também aqui um papel de destaque. Porém, se em As palavras e as coisas o estruturalismo (em todas as suas vertentes, da etnologia à psicanálise) aparece ao lado das reflexões sobre a linguagem (da filosofia analítica às experiências literárias) como uma saída possível à problemática do homem presente nas ciências humanas e na filosofia, em A arqueologia do saber o estruturalismo faz par com aquilo que Foucault chama genericamente de "História das ideias", que compreende a história das ciências e da filosofia, e aparece como solução aos problemas de uma concepção tradicional da história.

Segundo Foucault, a sua atualidade é marcada pela oposição entre dois tipos de pensamento sobre a história ${ }^{127}$. O primeiro, o da história propriamente dita, como diz Foucault, tende a pensar a história como um processo contínuo e "parece apagar, em benefício das estruturas fixas, a irrupção

126 Em primeiro lugar, vale notar que o próprio Foucault evoca Kant como referência ao termo "arqueologia". O filósofo afirma que Kant utilizou esta palavra para designar "a história do que torna necessário uma certa forma de pensar" (Cf. Foucault, "Les monstruosité de la critique", in $D E I$, p. 1089). E na nota do livro de Foucault, encontramos a passagem do texto kantiano. Trata-se de um texto de 1804, "Quais são os progressos reais da metafísica na Alemanha desde os tempos de Leibniz e Wolf?". Diz Kant, citado por Foucault: "Uma história filosófica da filosofia é ela mesma possível não historicamente ou empiricamente, mas racionalmente, ou seja, a priori. Pois, ainda que ela estabeleça fatos de Razão, não é da narrativa histórica que ela os tira, mas ela os tira da natureza da Razão humana a título de arqueologia filosófica". Lebrun, contudo, lembra que Suzanne Bachelard, em Logique de Husserl, de 1957, atenta para o fato que o termo "arqueologia" é caro a Husserl (Cf. Lebrun, "Note sur la phénoménologie...", p. 48). Para Lebrun, então, a referência de Foucault para o termo talvez fosse Husserl. Por outro lado, Jean Zoungrana, em Michel Foucault un parcours croisé: Lévi-Strauss, Heidegger, sugere que Foucault usara o termo pela primeira vez em sua introdução ao texto de Binswanger, Le rêve et l'existence, de 1954, sob inspiração freudiana que, em "Constructions dans l'analyse", in Résultats, idées, problémes, aproxima o trabalho do analista com o do arqueólogo, já que ele também procura trazer à superfície as verdades inconscientes do discurso do analisando. Mas Zoungrana lembra que o termo ainda pode ter inspiração em Dumézil que, em L'Héritage indo-européen à Rome, de 1949, fala em "arqueologia das representações e dos comportamentos", um método que seria mais atento "aos conceitos e aos sistemas de conceitos que se encontram depositados na linguagem, nas lendas e nas instituições” (Dumézil apud Zoungrana, p. 164).

127 Cf. Foucault, A arqueologia do saber, p. 4. 
dos acontecimentos"128; o segundo tipo de pensamento toma a história em suas descontinuidades, e "parece multiplicar as rupturas e buscar todas as perturbações da continuidade"129.

Foucault inicia o livro caracterizando a primeira corrente:

Há dezenas de anos que a atenção dos historiadores se voltou, de preferência, para longos períodos, como se, sob as peripécias e seus episódios, eles se dispusessem a revelar os equilíbrios estáveis e difíceis de serem rompidos, os processos irreversíveis, as regulações constantes, os fenômenos tendenciais que culminam e se invertem após continuidades seculares, os movimentos de acumulação e as saturações lentas, as grandes bases imóveis e mudas que o emaranhado das narrativas tradicionais recobria com toda uma densa camada de acontecimentos ${ }^{130}$.

O filósofo, como sempre, é lacônico quando se trata de dizer a quem se refere. Podemos, porém, supor que se refira aqui em geral à Escola dos Annales, fundada no final da década de 20 por Lucien Febvre e Marc Bloch e que teve grande influência na historiografia francesa do século $\mathrm{XX}^{131}$. Poderíamos ainda arriscar que, mais especificamente, Foucault se refira a Fernand Braudel que publica, em 1949, sua tese de doutorado intitulada $O$ mediterrâneo e o mundo mediterrâneo na época de Felipe II ${ }^{132}$.

A segunda corrente de pensamento da época de Foucault é aquela que se atém ao descontínuo e às rupturas. Foucault chama genericamente esse pensamento de "História das ideias", e é da seguinte maneira que o filósofo marca a especificidade desta forma de pensar:

\begin{abstract}
o grande problema que se vai colocar - que se coloca - a tais análises históricas não é mais saber por que caminhos as continuidades se puderam estabelecer; de que maneira um único e mesmo projeto pôde-se manter e constituir, para tantos espíritos diferentes e sucessivos, um horizonte único; que modo de ação e que suporte implica o jogo das transmissões, das retomadas, dos esquecimentos e das repetições; como a origem pode estender seu reino bem além de si própria e atingir aquele desfecho que jamais se deu - o problema não é mais a tradição e o rastro, mas o recorte e o limite; não é mais o fundamento que se perpetua, e sim as transformações que valem como fundação e renovação dos fundamentos ${ }^{133}$.
\end{abstract}

Alguns expoentes dessa segunda corrente de pensamento citados por Foucault são: Bachelard (com a ideia de limites epistemológicos), Canguilhem (com a ideia de deslocamento e transformação dos conceitos), Michel Serres (com seu estudo sobre a história da matemática), Guéroult (que desconsidera a influência da tradição e das continuidades culturais para compreender "a arquitetônica dos sistemas" de um texto) e, por fim, Althusser (em seu estudo sobre Marx com a ideia de corte epistemológico). Além disso, acrescenta Foucault, faz parte também da corrente

\footnotetext{
${ }^{128}$ Cf. Foucault, A arqueologia do saber, p. 6.

${ }^{129}$ Foucault, A arqueologia do saber, p. 6.

${ }^{130}$ Idem, p. 3.

${ }^{131}$ Cf. Foucault, "Michel Foucault explique sin dernier livre", in DE I, p. 801.

132 Em uma entrevista de 1967 Foucault afirma que Braudel se posiciona contra a história nos moldes de Michelet, que seria uma história linear e evolutiva, que se pergunta basicamente pelas causas e dá papel central da consiência do sujeito (Cf. Foucault, “Qui êtes-vous, professeur Foucault?”, in DE I, p. 635).
}

${ }^{133}$ Foucault, A arqueologia do saber, p. 6. 
descontinuísta as análises literárias que procuram pela unidade de um texto em sua estrutura interna e não no espírito de uma época, nas filiações a grupos, escolas, gerações ou movimentos, muito menos na subjetividade do autor. E aqui parece, então, que Foucault cita indiretamente mais um estruturalista: Roland Barthes ${ }^{134}$.

Apesar das diferenças entre esses dois modos de pensar a história, pelas continuidades ou pelas rupturas, ressalta Foucault, ambos tendem a enfrentar um mesmo problema: o problema do documento. É evidente que a relação com o documento é um problema tão antigo quanto a disciplina histórica. Porém, na modernidade, diz Foucault, qualquer saber histórico deve se deparar ou enfrentar uma concepção bem específica de documento: aquela que o considera como um rastro que deve ser interpretado e que deve trazer à luz uma memória milenar. E, para Foucault, o que haverá de comum entre a história dos longos períodos ou a história das mentalidades e as concepções descontinuistas da história é que ambas verão o documento não como dado com significado à espera de ser interpretado, mas como uma materialidade que deve ser elaborada, ordenada e trabalhada. Essa "nova história", diz Foucault,

considera como sua tarefa primordial, não interpretá-lo [o documento], não determinar se diz a verdade nem qual é seu valor expressivo, mas sim trabalhá-lo no interior e elaborá-lo: ela o organiza, recorta, distribui, ordena e reparte em níveis, estabelece séries, distingue o que é pertinente do que não é, identifica elementos, define unidades, descreve relações. O documento, pois, não é mais, para a história, essa matéria inerte através da qual ela tenta reconstruir o que os homens fizeram ou disseram, o que é passado e o que deixa apenas rastros: ela procura definir, no próprio tecido documental, unidades, conjuntos, séries, relações ${ }^{135}$.

Assim, se Foucault nota, em seu presente, uma oposição entre dois modos de pensar a história, ele considera essa oposição entre continuístas e descontinuístas somente um efeito de superfície de uma oposição mais fundamental: a de uma "história nova" que trata o documento

\footnotetext{
${ }^{134}$ Lembremos, pois, da disputa entre Barthes e Raymond Picard sobre a questão do autor. Disputa que parece começar com a publicação do livro de Barthes, Sur Racine, em 1965, que reprova a crítica literária que se baseia na biografia do autor e que, em seguida, é colocado em questão por Picard em Nouvelle crithique ou nouvelle imposture. Em 1968, Barthes publica, então, o artigo "La mort de l'auteur". Mas pode ser também que Foucault refira-se a Maurice Blanchot, que em 1953 publica "Où maintenant, qui maintenant", um comentário sobre o romance de Beckett publicado no mesmo ano, O inominável, que tematiza a dissolução do "eu” e do autor. Cf. também texto de Blanchot "La folie par excellence" que serve de prefácio ao livro de Jasper sobre Strindberg, Van Gogh, Hölderlin, Swedenborg. Foucault chega a Blanchot graças a Sartre que em Situações I, de 1948, faz muitos comentários sobre ele e Bataille (Cf. Eribon, Michel Foucault, p. 71). Sobre a influência de Blanchot e Bataille no que diz respeito ao tema da morte do homem, cf. Foucault, "Qui êtes-vous, professeur Foucault?", in DE I, p. 642.
}

135 Foucault, A arqueologia do saber, p. 7. 
como algo a ser transformado, e a "história tradicional" que o toma como algo a ser interpretado ${ }^{136}$. E aqui voltamos à importância do termo arqueologia no contexto do pensamento moderno sobre a história. Pois, segundo Foucault, a história, em seus dias, em suas duas correntes opostas, se volta para a arqueologia ${ }^{137}$.

A arqueologia é, pois, com as palavras de Foucault, "a disciplina dos objetos sem contexto"138. Ela é, por excelência, a ciência que se depara com uma multiplicidade desordenada de objetos e que deve trabalhar a fim de dar ordem e sentido a eles colocando-os em relação. Nesse sentido, portanto, a arqueologia é a disciplina que, de modo mais paradigmático, funciona como antípoda da concepção tradicional de história. Sendo assim, mesmo que não saibamos ainda ao certo qual seja a concepção de história de Foucault, o fato de ele chamar seu método de arqueológico nos faz supor que ele, antes de tudo, é contrário à ideia tradicional de história. Ou seja, contrário à ideia de que os acontecimentos históricos, assim como seus registros - os documentos - , sejam simplesmente dados que possuem um significado prévio e que estão à espera de serem compreendidos; contrário à ideia de que os acontecimentos e fatos históricos sejam efeitos de uma relação causal simples; contrário à ideia de que a história seja a história de uma longa série de progressos: contrário, portanto, à ideia de teleologia da razão ou evolução do pensamento humano; por fim, contrário à ideia de uma história que se reduza a um esquema linear, uma história totalizante ou, nos termos de Foucault, uma história global que nos forneça uma significação comum a todos os fenômenos de um período ${ }^{139}$.

Com efeito, as análises de Foucault evidenciam o quanto ele se distancia dessa "história global" e totalizante e o quanto ele se avizinha de uma concepção de história que está prenhe de metodologia estruturalista. Sim. Pois Foucault reconhece que a "nova história" compartilha muitos dos problemas metodológicos dos saberes ditos estruturalistas, como a linguística, a etnologia, a

\footnotetext{
${ }^{136}$ Cf. Foucault, A arqueologia do saber, p. 8. Numa entrevista de 1969, Foucault volta à proximidade entre a história dos Annales e a história das ideias e a explica melhor: "Sou inteiramente oposto a certa concepção de história que toma como modelo uma espécie de grande evolução contínua e homogênea, uma espécie de grande vida mítica. Hoje, os historiadores sabem bem que a massa de documentos históricos podem ser combinados segundo diferentes séries que não têm nem os mesmos traços nem o mesmo tipo de evolução. A história da civilização material (técnicas agrícolas, habitat, instrumentos domésticos, meios de transporte) não se desenvolve da mesma maneira que a história das instituições políticas ou a história dos fluxos monetários. O que Marc Bloch, Febvre e Braudel mostraram para a história tout court, podemos mostrar, creio, para a história das ideias, do conhecimento, do pensamento em geral" (Foucault, "La naissance du monde", in DE I, p. 815).

${ }^{137}$ Cf. Foucault, A arqueologia do saber, p. 8.

${ }^{138}$ Cf. Foucault, A arqueologia do saber, p. 8.

${ }^{139}$ Cf. Foucault, A arqueologia do saber, pp. 9-12.
} 
economia, a análise literária e da mitologia ${ }^{140}$. Metodologia que não se preocupa tanto com a compreensão e a explicação, que não se preocupa em dar conta da evolução e dos resultados da história e que, por fim, não se coloca como meta a totalidade. Em uma entrevista de 1967, afirma Foucault: "Depois de Saussure, vemos surgir metodologias que se apresentam como metodologias deliberadamente parciais." 141 Porém, mais uma vez, não nos caberá discutir se Foucault, enfim, é ou não um estruturalista. Que ele guarda semelhanças com tal corrente de pensamento não há dúvidas, porém, especificar essa vizinhança, assim como indicar os pontos de divergência, deixamos para outro momento. Gostaríamos de insistir aqui sobre um ponto comum entre essa nova concepção de história, à qual se filia Foucault ao chamar seu método de arqueológico, e o estruturalismo. Que ponto de convergência é esse? Ambos se posicionam contra os antropologismos e humanismos que colocam o homem como centro da análise histórica.

Assim, se vínhamos dizendo que o que avizinha a historiografia francesa do século XX, a história das ideias, o pensamento estruturalista e o próprio Foucault, é a oposição de todos esses saberes a uma noção tradicional de história, agora, é preciso ressaltar que todos esses saberes se opõem também a certa concepção de homem que é correlata a essa noção tradicional da história. Que concepção de homem é essa? Aquela que, segundo Foucault, nasce a partir da reflexão kantiana do transcendental ${ }^{142}$.

Como vimos no capítulo 1, a nova figura do homem que surge no final do século XVIII, não com Kant, mas a partir dele, é aquela de um ser constitutivamente alienado de si mesmo; um ser que em suas próprias condições de possibilidade, em sua própria função fundadora de ser que vive, trabalha e fala, escapa a si mesmo. Ora, dirá Foucault, a noção global de história que se desenrola

\footnotetext{
140 Vale ressaltar aqui quais seriam estes problemas metodológicos, pois, a nosso ver, eles coincidem com diversos problemas de método enfrentados pelo próprio Foucault em suas análises históricas. Foucault cita ao menos 6 desses problemas: 1) como construir um corpus coerente e homogêneo a partir da diversidade dos documentos (corpus fechado, aberto, indefinido); 2) como estabelecer um critério de escolha dos documentos a serem trabalhados (o critério pode ser tratar a massa de documentos em exaustão, pode-se trabalhar com estatística, determinar os elementos mais representativos); 3) como definir o nível de análise pertinente para a compreensão do documento (pode-se salientar indicações numérias, referências a acontecimentos, instituições e práticas, pode-se focar nas palavras empregadas e suas regras de uso ou na estrutura formal das proposições); 4) que método utilizar para fazer a análise dos documentos (tratamento quantitativo, decomposição a partir de traços assinaláveis, decifração interpretativa, analisar frequências e distribuições); 5) como delimitar os conjuntos que articulam o material estudado (delimitar conjunto por regiões, por períodos); 6) como determinar as relações entre os documentos (relações numéricas e lógicas, relações causais, relação significante-significado). Ora, a todas essas dificuldades, espera-se que o livro-método de Foucault possa dar uma resposta.
}

${ }^{141}$ Foucault, “Qui êtes-vous, professeur Foucault?”, in DE I, p. 638.

$142 \mathrm{Na}$ conclusão de $A$ arqueologia do saber, Foucault comenta a problemática transcendental nos termos de uma crise: “crise em que estamos há muito tempo e cujo âmbito não pára de crescer: crise em que estão comprometidas a reflexão transcendental com a qual se identificou a filosofia desde Kant; a temática da origem, da promessa do retorno pela qual evitamos a diferença de nosso presente; um pensamento antropológico que consagra todas as interrogações à questão do ser do homem, e permite evitar a análise da prática; todas as ideologias humanistas; e - enfim e sobretudo - o status do sujeito" (Foucault, A arqueologia do saber, p. 229). 
ao longo dos séculos XIX e XX é o correlato indispensável dessa nova figura do homem ${ }^{143}$. Ou seja, o homem, enquanto figura originária e fundamentalmente alienada, é o correlato indispensável dessa concepção de história que está sempre em busca da origem, que nos leva a percorrer de volta a linha dos antecedentes, "a reconstruir tradições, a seguir curvas evolutivas, a projetar teleologias"144. E Foucault justifica essa correlação indispensável: uma concepção global, totalizante e teleológica da história é a garantia de que tudo o que escapa ao sujeito em função de sua condição de ser finito possa um dia lhe ser devolvido por meio da consciência histórica; a garantia de que ele não perca sua soberania de sujeito determinante e sujeito fundador de sínteses e significações. Com as palavras de Foucault, a história em sua concepção tradicional passa, então, a ser:

a certeza de que o tempo nada dispersará sem reconstituí-lo [o sujeito] em uma unidade recomposta; a promessa de que o sujeito poderá, um dia - sob a forma da consciência histórica -, se apropriar, novamente, de todas essas coisas mantidas a distância pela diferença, restaurar seu domínio sobre elas e encontrar o que se pode chamar sua morada ${ }^{145}$.

Ora, encontramos aqui um paralelismo entre a concepção de uma história global e totalizante e os temas de uma analítica da finitude, pois vimos já que também as analíticas da finitude são marcadas pela tentativa de superar a finitude e os limites constitutivos do homem por meio de um conhecimento empírico e positivo dessa finitude. Lembremos pois que, segundo Foucault, as analíticas da finitude podem ser definidas como essa tentativa de conhecer a si mesmo como ser naturalmente finito; como ser cuja finitude lhe é estranha e que lhe escapa, mas que, por isso mesmo, o coloca sempre na situação de tentar apreendê-la.

E se o problema das analíticas da finitude estava no fato de que pretendiam conhecer aquilo que escapa a qualquer experiência humana, a essência humana em sua finitude radical, o problema das histórias globais estará no fato de que pretendem conhecer a história referindo-se exclusivamente à atividade sintética do sujeito, afinal, é só ele, por meio da atividade sintética de sua consciência, que seria capaz de ver um documento e lhe restituir seu sentido, só ele seria capaz de compreender o curso e o progresso da razão, só ele seria capaz de trazer os fatos à memória e de reconhecer uma tradição. E se, segundo Foucault, as analíticas da finitude dormiam no sono

\footnotetext{
${ }^{143}$ Cf. Foucault, A arqueologia do saber, p. 14.

144 Foucault, A arqueologia do saber, p. 13.

145 Idem, p. 14. Foucault nega que faz histórias nos moldes da perspectiva do progresso, acreditando que a sucessão histórica tende ao progresso; afirma que deve isso aos historiadores da ciência: "Tenho essa precaução de método, este ceticismo radical [...] que, por princípio, não toma o ponto em que estamos como o fim de um progresso que precisaríamos reconstituir na história [...]. O que não quer dizer que não se tente reconstituir processos generativos, mas sem os afetar de uma positividade, de uma valoração" (Foucault, "Entretien sur la prison: le livre et sa méthode", in $D E$ I, p. 1618).
} 
antropológico, também a história tradicional dorme num sono tranquilo. Sono tranquilo, pois nela a soberania do sujeito está resguardada, pois nela há espaço para o repouso, a certeza e a reconciliação ${ }^{146}$. Ou seja, há espaço para a totalização ${ }^{147}$.

Assim, se já em 61, na tese complementar, Foucault preconizava a necessidade de se despertar do sono antropológico das analíticas da finitude, no livro de 69 ele insiste que "se trata de definir um método de análise histórica que esteja liberado do tema antropológico"148. Um método que liberte a história de "sua sujeição transcendental"; um método que tome a história em sua dispersão e "que nenhum horizonte prévio poderia tornar a fechar"; que abra a história "a uma temporalidade que não prometeria o retorno de nenhuma aurora"; que a liberte "da esfera da origem perdida e reencontrada em que estava presa". Enfim, diz Foucault, na conclusão do livro, era preciso um método que mostrasse que a história não pode ter papel revelador do momento transcendental ${ }^{149}$. Ou seja, que a análise histórica não pode ser o lugar onde o sujeito volta a se encontrar soberano, fundador e doador das sínteses (sujeito constituinte) e do sentido (sujeito psicológico). Para Foucault, esse método será a arqueologia. Como exatamente funciona esse método de análise histórica e qual seu objeto é o que procuraremos examinar a seguir.

\section{A suspensão do transcendental}

Partamos da curiosa e excêntrica conclusão do livro. Foucault simula um debate com um possível interlocutor; o interlocutor parece um pouco irritado com o teor do livro e questiona seu autor com temas que até hoje parecem seduzir os críticos do filósofo. O primeiro problema que ele aponta a Foucault, por exemplo, parece ser o mesmo tratado por Habermas em seu $O$ discurso filosófico da modernidade. Assim como Habermas, o crítico imaginário parece sugerir que Foucault

\footnotetext{
${ }^{146}$ Cf. Foucault, A arqueologia do saber, p. 17.

147 Como já dissemos, é sempre muito difícil saber quem é o foco dos comentários e críticas de Foucault. Sugerimos que o termo "história nova" talvez se refira à escola dos anales como um todo; vimos também, porém, que talvez se trate somente da segunda geração da escola que teria sofrido mais influência do estruturalismo e se posicionado de modo mais radical contra a ideia de uma história totalizante. Uma concepção de história totalizante, por outro lado, pode dizer respeito tanto à primeira geração da Escola dos Annales quanto à tradição historiográfica anterior a ela, a da escola metódica, e ainda à história nos moldes de Michelet. Mas é provável também que a grande oposição à "história nova" a que Foucault se refere não diga respeito a nenhuma concepção de história anterior à decada de 50, mas a uma concepção de história contemporânea a ela: a concepção de Sartre. É famosa a polêmica entre Sartre e Lévi-Strauss no que tange à história. A grande crítica de Foucault a Sartre é em relação à sua pretensão totalizante. Cf. Foucault, "Qui êtes-vous professeur Foucault?", in DE I, p. 638: a fenomenologia, diz Foucault, "é um método totalizante"; quer dar conta de tudo, do cogito e do que é anterior a ele.
}

${ }^{148}$ Foucault, A arqueologia do saber, p. 18.

${ }^{149}$ Idem, p. 228. 
tenha caído numa "contradição performativa"150. Ou seja, que tenha negado que o discurso tem como condição de possibilidade a subjetividade de seu autor assim como o contexto histórico bem preciso dentro do qual ela está inserido, mas que inevitavelmente Foucault contou com sua subjetividade e com seu contexto histórico para escrever o que escreveu. O suposto adversário de Foucault, então, denuncia:

A exemplo de uma certa forma de linguística, você procurou dispensar o sujeito falante: acreditou que se podia livrar o discurso de todas as suas referências antropológicas e tratá-lo como se jamais tivesse sido formulado por alguém, como se nunca tivesse nascido em circunstâncias particulares, como se não fosse atravessado por representações, como se não se dirigisse a ninguém. Finalmente, você aplicou-lhe um princípio de simultaneidade: recusou-se a ver que o discurso, diversamente talvez da língua, é essencialmente histórico [...] e que não se podia analisá-lo fora do tempo em que se desenvolveu ${ }^{151}$.

Em sua segunda arguição, ele volta ao problema: “A história das análises, onde a subjetividade se esquiva, guarda consigo sua própria transcendência”152.

Foucault, então, aproveita para esclarecer aquele que, talvez, tenha sido um dos maiores mal-entendidos acerca de seu trabalho. Diz Foucault a seu interlocutor imaginário: "Você tem razão: ignorei a transcendência do discurso; recusei-me, descrevendo-o, a relacioná-lo com uma subjetividade; não acentuei, em primeiro lugar, e como se devesse ser a forma geral, seu caráter diacrônico"153. O mais importante de sua resposta, porém, vem a seguir. Continua o filósofo:

Se suspendi as referências ao sujeito falante, não foi para descobrir leis de construção ou formas que seriam aplicadas da mesma maneira por todos os sujeitos falantes, nem para fazer falar o grande discurso universal que seria comum a todos os homens de uma época. [...] não neguei a história;

150 Rui Magalhães nos esclarece que, em Habermas, a noção de "contradição performativa" inspira-se em Karl-Otto
Apel, particularmente no texto intitulado "A racionalidade da comunicação humana na perspectiva da pragmática
transcendental". Segundo Magalhães, que cita o próprio Apel, esta noção designa "uma auto-contradição pragmático-
transcendental, pela qual entende uma contradição performativa entre o conteúdo de uma proposição e o conteúdo
intencional e auto-referencial (implícita ou explicitamente) performativo do acto de propor esta proposição no quadro
do discurso argumentativo" (Magalhães, "Foucault e Habermas: a propósito de uma crítica filosófica", p. 192). A
questão da contradição performativa é apresentada por Habermas na seguinte passagem: "me deterei na questão de
saber se Foucault consegue conduzir uma crítica radical da razão na forma de uma historiografia das ciências humanas,
estabelecida arqueologicamente e ampliada à genealogia, sem se enredar nas aporias dessa empresa auto-
referencial" (Habermas, O discurso filosófico da modernidade, p. 346). Com outras palavras, o que Habermas propõe-
se a investigar é como Foucault pode escrever uma historiografia da razão "se o trabalho do historiador tem de se mover
por sua vez no horizonte da razão" (Ibidem). E a conclusão de Habermas é, de fato, a de que Foucault cai em
contradição performativa ao situar-se como sujeito transcendente à história e, por isto mesmo, como sujeito
transcendental da reflexão crítica. Diz Habermas: "Valendo-se dessa posição de contrapoder, adquire uma perspectiva
que deve estender-se para além das perspectivas do poder. Dessa perspectiva, transcenderiam todas as pretensões de
validade que se constituem dentro da jurisdição do poder" (Idem, p. 392).

${ }^{151}$ Foucault, A arqueologia do saber, p. 224.

${ }^{152}$ Idem, p. 226.

${ }^{153}$ Idem, p. 224. 
mantive em suspenso a categoria geral e vazia de mudança para fazer aparecer transformações de níveis diferentes ${ }^{154}$.

Note-se bem que Foucault afirma ter ignorado a transcendência do discurso. Isso não significa que a tenha negado. Seu acento ou seu enfoque simplesmente não se direcionou a ela. Ele simplesmente a colocou em suspenso. Um recurso, aliás, muito frequente na filosofia quando se trata de recortar ou selecionar o aspecto da realidade que se pretende examinar. No caso, Foucault recortou e excluiu de suas considerações as questões sobre o fundamento da experiência, sobre suas condições de possibilidade subjetivas e históricas. Ou seja, colocou em suspenso todos os elementos transcendentais que teriam por finalidade fundar a experiência. Em uma entrevista de 1967, Foucault insiste que tal suspensão não é sinônimo de negação:

a partir do momento que não se pode mais descrever tudo, é ocultando o cógito, colocando de certo modo entre parênteses esta ilusão primeira do cógito, que nós podemos fazer aparecer sistemas inteiros de relação que de outro modo não seriam descritíveis. Por conseguinte, eu não nego o cógito, limito-me a observar que sua fecundidade metodológica não é, enfim, tão grande quanto se havia acreditado $^{155}$.

\section{Sobre a suspensão do seu contexto histórico, o filósofo continua:}

$\mathrm{Eu}$ realmente seria cego se negligenciasse, olhando minha própria situação, o que tanto coloquei em evidência. Sei perfeitamente que estou situado no interior de um contexto. O problema consiste, então, em saber como podemos ter a consciência de um tal contexto e mesmo, por assim dizer, integrá-lo, deixar que ele exerça seus efeitos sobre seus próprios discursos, sobre os discursos que estamos tendo agora. Você diz que é inevitável ser filósofo ao passo que é inevitável pensar a totalidade [...]. Mas você tem certeza que a filosofia consiste precisamente nisso? Quero dizer que a filosofia que procura pensar a totalidade poderia perfeitamente ser somente uma das formas possíveis de filosofia, uma das formas possíveis que foi efetivamente a via real do pensamento filosófico do século passado, desde Hegel; mas, poderíamos muito bem pensar hoje que a filosofia não consiste mais nisso ${ }^{156}$.

Ora, as críticas que acusam Foucault de "contradição performativa", que o acusam de ter negado a condição de possibilidade de seu próprio discurso, são acusações vãs. Elas simplesmente não compreendem que jamais Foucault tenha negado a existência do contexto histórico, assim

\footnotetext{
${ }^{154}$ Foucault, A arqueologia do saber, pp. 224-5. Também no primeiro capítulo, Foucault fala em "suspensão": "Essas formas de continuidade, todas essas sínteses que não problematizamos e que deixamos valer de pleno direito, é preciso, pois, mantê-las em suspenso. Não se trata, é claro, de recusá-las definitivamente, mas sacudir a quietude com a qual as aceitamos" (Idem, p. 28, grifo nosso). Cf. ainda p. 32 sobre a justificativa de recusar o sujeito psicológico. No início do segundo capítulo, Foucault mais uma vez explica que não se trata de recusar certas unidades do discurso, mas somente de colocá-las em suspenso a fim encontrar outros critérios de sínteses: "que se tenha posto de lado, não de forma definitiva, mas por algum tempo e por uma questão de método, as unidades tradicionais do livro e da obra; que se deixe de tomar como princípio de unidade as leis de construção do discurso (com a organização formal que daí resulta), ou a situação do sujeito falante (com o contexto e o núcleo psicológico que a caracterizam); que não mais se relacione o discurso ao solo inicial de uma experiência nem à instância a priori de um conhecimento; mas que nele mesmo o interroguemos sobre as regras de sua formação" (Idem, p. 89). Mais adiante, ao discorrer sobre a análise do enunciado, Foucault confessa que para que o enunciado torne-se "visível" é necessária uma conversão do olhar e da atitude. Ou seja, mais um indício de que o método arqueológico conta com uma ação deliberada em recusar certos objetos da realidade em benefício de outro; ação que de certo modo aproxima o método de Foucault ao método fenomenológico da atitude natural e atitude fenomenológica. (Cf. Foucault, A arqueologia do saber, p. 126).
}

155 Foucault, "Qui êtes-vous, professeur Foucault?", in $D E I$, p. 638. Ainda sobre a suspensão das unidades transcendentais cf. "Sur l'archéologie des sciences. Réponse au Cercle d'épistémologie", in $D E I$, p. 734 e "Foucault", in $D E I I$, p. 1455.

${ }^{156}$ Foucault, “Qui êtes-vous, professeur Foucault?”, in DE I, p. 639. 
como a existência de uma subjetividade psicológica ou lógica, por trás de todo e qualquer discurso, mas que simples e deliberadamente se recusou a tomá-los como objeto de sua investigação. No que diz respeito ao sujeito, já quase no final da conclusão do livro, Foucault volta a insistir: ele de maneira alguma nega a existência do sujeito enquanto realizador de sínteses, de significado e enquanto condição necessária para a realização do discurso; o que ele nega, na verdade, é que esse sujeito seja soberano e que tenha direito exclusivo sobre o discurso ${ }^{157}$. A diferença entre uma e outra negação é tão grande quanto aquela que separa o que Foucault disse daquilo que seus críticos acreditam que ele tenha dito.

Mas, poderíamos nos perguntar o porquê da suspensão do transcendental. Não que esta seja uma pergunta muito pertinente, afinal, a meu ver, um filósofo deve poder pensar e selecionar como objeto de reflexão o que bem entender ${ }^{158}$. Porém, refletir sobre essa suspensão talvez nos faça ver melhor "o que sobra" quando se põe entre parênteses o transcendental.

Vimos que, de acordo com o diagnóstico de Foucault, desde Kant, a filosofia é tomada pela questão do transcendental. Questão que, se por um lado levou a filosofia a questões mais formais, como no caso da filosofia analítica e da linguagem, por outro, a afundou numa série de contradições, como é o caso das analíticas da finitude que antropologizaram e ontologizaram as considerações transcendentais. Ora, é principalmente a essa última linha de pensamento que Foucault quer se contrapor e, a nosso ver, é em função dessa contraposição que é necessário desconsiderar o transcendental. Mas afinal, o que sobra quando o transcendental é suspenso?

Primeiramente, sobra tudo aquilo que é da ordem do empírico. Ou seja, tudo aquilo que pode ser conhecido empiricamente, em sua multiplicidade e diferença, pela experiência. E aqui podemos fazer a primeira aproximação com a Antropologia pragmática de Kant, afinal, esta era descrita pelo próprio Foucault como coletânea de observações empíricas que não tem contato com uma reflexão sobre as condições da experiência ${ }^{159}$.

\footnotetext{
${ }^{157}$ Foucault, A arqueologia do saber, p. 234.

158 Essa, porém, não parece ser a opinião de Jean-Claude Margolin que não aceita como legítima a suspensão do transcendental operada por Foucault. Pelo menos é isso o que entendemos a partir da seguinte passagem de seu texto que critica duramente nosso autor: "Nenhum sistema de saber, nenhum campo epistemológico, pode colocar entre parênteses ou suprimir como uma hipótese inoportuna ou como um parâmetro incômodo, este índice de humanidade que ele supõe do início ao fim" (Margolin, "L’homme de Michel Foucault”, p. 333). Vale notar, contudo, como lembra Canguilhem, que colocar em suspenso o homem enquanto sujeito transcendental ou enquanto consciência absoluta não foi uma invenção ou uma decisão excêntrica de Foucault. Em 1947, Jean Cavaillé, em Sur la logique et la théorie de la science, teria já anunciado a necessidade de se substituir uma filosofia da consciência, do primado da consciência, por uma filosofia do conceito, do sistema e da estrutura (Cf. Canguilhem, "Mort de l'homme ou épuisement du Cogito?”, p. 273).

${ }^{159}$ Cf. Foucault, “Introduction à l'Anthropologie”, p. 41. Cf. também passagem de A arqueologia do saber, p. 23, onde Foucault afirma que suas pesquisas são empíricas.
} 
Mas o que exatamente do domínio empírico interessa a Foucault? E aqui mais uma vez notamos uma contiguidade entre a antropologia kantiana e a arqueologia de Foucault. Tal aproximação se deve justamente ao caráter pragmático de ambas. E esse é, parece, o segundo ganho que se tem com a suspensão das totalidades transcendentais.

Ainda na conclusão de A arqueologia do saber, afirma Foucault que, na dimensão empírica do discurso, interessam-lhe as "performances verbais"160. Ou seja, interessa-lhe aquilo que os homens fazem no campo da linguagem, como eles a utilizam.

O enunciado como práticas discursivas: o uso da linguagem e o caráter pragmático do discurso

\section{Como entender essas performances verbais?}

Em primeiro lugar, elas são os documentos analisados por Foucault. Seu foco, portanto, está naquilo que foi falado ou escrito. Para usar os termos de Foucault, interessam-lhe os enunciados. E do mesmo modo que a "história nova" inclina-se para a arqueologia, o método de Foucault consiste em recolher esses documentos discursivos ou enunciados e encontrar sua ordem, sua unidade. Afirma Foucault acerca desse domínio de análise:

Trata-se de um domínio imenso, mas que se pode definir: é constituído pelo conjunto de enunciados efetivos (quer tenham sido falados ou escritos), em sua dispersão de acontecimentos e na instância própria de cada um [...]. Aparece, assim, o projeto de uma descrição dos acontecimentos discursivos como horizonte para a busca das unidades que aí se formam ${ }^{161}$.

Mas atenção. Apesar de Foucault afirmar que a arqueologia pretende dar unidade a uma série de acontecimentos discursivos, é importante ter em mente que essa unidade não é totalizante; em nada ela tem a ver com uma unidade transcendental que funciona como fundamento do que é dito. Ela é, ao contrário, uma unidade parcial e lacunar que se refere a uma região empírica muito limitada ${ }^{162}$. Antes de ser uma unidade idêntica fundante, é uma unidade de multiplicidades que mais do que fundar servem para caracterizar uma situação singular. Nesse sentido, a episteme, nome utilizado por Foucault para se referir à unidade encontrada entre certos enunciados de um determinado período, não se refere ao espírito unitário de uma época, a uma forma única, constrangedora e soberana, de consciência. A episteme foucaultiana não é uma espécie de Weltanshaung $^{163}$. No texto que Foucault escreve para sua canditatura ao Collège de France, em

\footnotetext{
${ }^{160}$ Cf. Foucault, A arqueologia do saber, p. 121 e p. 224.

${ }^{161}$ Cf. Foucault, A arqueologia do saber, p. 30.

${ }^{162}$ Cf. Foucault, “Sur l'archéologie des sciences. Réponse au Cercle d'épistemologie”, in DE I, p. 737.

163 Cf. Foucault, "Rèponse à une question", in $D E I$, p. 705.
} 
1970, o filósofo insiste que a unidade que sempre procurou fazer aparecer em suas pesquisas estava longe de caracterizar o espírito geral de uma época, mas pretendia antes apontar para uma configuração coerente de uma região do conhecimento empírico ${ }^{164}$. Configuração que apesar de coerente e unitária é sempre provisória, está sempre aberta a revisões, a acréscimos e a transformações.

Dito isso, vale notar, em segundo lugar, que as performances verbais que interessam a Foucault, os enunciados, não interessam enquanto expressão de algum pensamento ou ideia, tampouco enquanto ato que atualiza as estruturas de uma língua. Interessam em si mesmos e em suas relações com os demais enunciados. Como vimos na citação acima, trata-se de encontrar a ordem, ou se quisermos utilizar um termo mais estruturalista, o sistema existente entre os enunciados. Tal ordem é aquilo que, segundo o filósofo, condiciona a existência dos enunciados, é aquilo que nos permite compreender a situação singular do que foi dito ou escrito ${ }^{165}$. Assim, não basta simplesmente localizar os enunciados em sua dispersão de acontecimento, como diz Foucault; é preciso dar a eles uma unidade, isto é, é preciso compreendê-los no interior de um sistema ordenado, é preciso apreendê-los em sua regra de coexistência com os demais enunciados. Afinal, deve haver uma regra que condiciona aquilo que é dito já que, retomando as palavras de $A$ ordem do discurso, "não se tem o direito de dizer tudo, que não se pode falar de tudo em qualquer circunstância, que qualquer um, enfim, não pode falar de qualquer coisa"166. Esse sistema ordenado que condiciona a existência do enunciado, Foucault chama de "formação discursiva" e compreende quatro dimensões diferentes: a do sujeito da enunciação, a do objeto a que se refere a enunciação, a dos conceitos utilizados e a das escolhas temáticas.

Percebe-se, assim, a complexidade com que devem ser analisados os enunciados, os documentos históricos ou as práticas discursivas que interessam a Foucault. Eles só adquirem sentido quando pensados no interior de um sistema mais geral (a formação discursiva ou o

\footnotetext{
${ }^{164}$ Cf. Eribon, Michel Foucault, p. 229.

165 Foucault, A arqueologia do saber, p. 31.

${ }^{166}$ Foucault, A ordem do discurso, p. 9.
} 
discurso $^{167}$ ) constituído por relações de, no mínimo, quatro dimensões diferentes. E o filósofo resume como se deve analisar a unidade de uma formação discursiva, tomando o exemplo da história natural:

A arqueologia pode assim [...] constituir a árvore de derivação de um discurso, por exemplo, o da história natural. Ela colocará, junto à raiz, como enunciados reitores, os que se referem à definição das estruturas observáveis e do campo de objetos possíveis, os que prescrevem as formas de descrição e os códigos perceptivos de que ele pode servir-se, os que fazem aparecerem as possibilidades mais gerais de caracterização e abrem, assim, todo um domínio de conceitos a ser construídos; enfim, os que, constituindo uma escolha estratégica, dão lugar ao maior número de opções ulteriores ${ }^{168}$.

O enunciado, portanto, não está, segundo Foucault, naquilo que o seu autor quis dizer, no sujeito transcendental e lógico que o possibilita, nem tampouco nas regras sintáticas da língua utilizadas e atualizadas por ele. Não. Não se trata de compreender nem o sentido psicológico, nem o sentido lógico, nem o gramatical dos ditos e escritos. Trata-se, antes, de apreendê-los numa complexidade de dimensões que vão além da língua e do sujeito lógico e psicológico. Confirma Foucault: "Esta massa de coisas ditas, eu encaro não do lado da língua, do sistema linguístico que elas colocam em ação, mas do lado das operações que as fizeram nascer"169; ou seja, do lado das operações que fizeram nascer certo tipo de objeto e de sujeito, e que fizeram nascer determinados conceitos e temas. É preciso, pois, se perguntar pelas práticas que se deram no interior de cada uma das 4 dimensões da formação discursiva. Mas não só. É preciso também perguntar pelas regras que ordenaram essas práticas, pelas relações que as práticas de uma dimensão têm com as práticas de outra dimensão, e, por fim, pela maneira como se articulam as práticas do dizer, práticas discursivas, e práticas de outras ordens (técnicas, econômicas, sociais, políticas). Resumindo com as palavras do filósofo: "trata-se de uma análise do discurso na dimensão de sua exterioridade" 170.

167 Foucault define discurso como "conjunto de enunciados que se apoia em um mesmo sistema de formação" (Foucault, A arqueologia do saber, p. 122). Se Foucault chama de "formação discursiva" o sistema ordenado ou de regras a que pertence um enunciado, o filósofo chamará de "saber" aquilo de que se pode falar do interior de uma formação discursiva. Apesar, porém, desta distinção, a meu ver, as definições que Foucault dá de uma e outra noção são quase idênticas. Vejamos: "Um saber é aquilo de que podemos falar em uma prática discursiva que se encontra assim especificada: o domínio constituído pelos diferentes objetos que irão adquirir ou não um status científico (o saber da psiquiatria, no século XIX, não é a soma do que se acredita fosse verdadeiro; é o conjunto das condutas, das singularidades, dos desvios de que se pode falar no discurso psiquiátrico); um saber é, também, o espaço em que o sujeito pode tomar posição para falar dos objetos de que se ocupa em seu discurso (neste sentido, o saber da medicina clínica é o conjunto das funções de observação, interrogação, decifração, registro, decisão, que podem ser exercidas pelo sujeito do discurso médico); um saber é também o campo de coordenação e de subordinação dos enunciados em que os conceitos aparecem, se definem, se aplicam e se transformam (neste nível, o saber da história natural, no século XVIII, não é a soma do que foi dito, mas sim o conjunto dos modos e das posições segundo os quais se pode integrar ao já dito qualquer enunciado novo); finalmente, um saber se define por possibilidades de utilização e de apropriação oferecidas pelo discurso (assim, o saber da economia política, na época clássica, não é a tese das diferentes teses sustentadas, mas o conjunto de seus pontos de articulação com outros discursos ou outras práticas que não são discursivas)" (Idem, pp. 204-5, grifo nosso).

${ }^{168}$ Idem, p. 166, grifo nosso.

${ }^{169}$ Foucault, “La naissance d'un monde”, in DE I, pp. 814-5.

${ }^{170}$ Foucault, “Réponse à une question”, in $D E I$, p. 710. 
Foucault justifica, então, este tipo de análise do discurso:

se isolamos, em relação à língua e ao pensamento, a instância do acontecimento enunciativo não é para disseminar uma poeira de fatos e sim para estarmos seguros de não relacioná-la com operadores de síntese que sejam puramente psicológicos (a intenção do autor, a forma de seu espírito, o rigor de seu pensamento, os temas que o obcecam, o projeto que atravessa sua existência e lhe dá significação) e podermos apreender outras formas de regularidade, outros tipos de relações. Relações entre enunciados (mesmo que escapem à consciência do autor; mesmo que se trate de enunciados que não têm o mesmo autor; mesmo que os autores não se conheçam); relações entre grupos de enunciados assim estabelecidos (mesmo que esses grupos não remetam aos mesmos domínios nem a domínios vizinhos; mesmo que não constituam o lugar de trocas que podem ser determinadas); relações entre enunciados ou grupos de enunciados e acontecimentos de uma ordem inteiramente diferente (técnica, econômica, social, política). Fazer aparecer, em sua pureza, o espaço em que se desenvolvem os acontecimentos discursivos não é tentar restabelecê-lo em um isolamento que nada poderia superar; não é fechá-lo em si mesmo; é tornar-se livre para descrever, nele e fora dele, jogos de relações ${ }^{171}$.

Assim, ao passo que o enunciado diz respeito ao jogo de relações existentes entre diferentes práticas e operações, o que foi efetivamente dito ou escrito, o enunciado, não pode ser compreendido simplesmente em seu sentido gramatical, lógico ou locutório. O enunciado não equivale a uma proposição que afirma ou nega algo. Diz Foucault: "Não acredito que a condição necessária e suficiente para que haja enunciado seja a presença de uma estrutura proposicional definida"172. E Foucault nos dá um exemplo: as proposições "ninguém ouviu" e "é verdade que ninguém ouviu" são, do ponto de vista lógico, iguais; do ponto de vista do discurso, porém, elas se referem a dois enunciados distintos. Mas o enunciado também não deve ser compreendido enquanto frase que possua ou não sentido em função de sua estrutura gramatical. Um quadro classificatório das espécies botânicas, esclarece Foucault, assim como uma árvore genealógica, um livro contábil, as estimativas de um balanço comercial, tudo isso "é constituído de enunciados, não de frases"173. E podemos retomar mais um exemplo da diferença entre proposição, frase e enunciado:

Podemos encontrar performances verbais que são idênticas do ponto de vista da gramática [...]; que são igualmente idênticas do ponto de vista da lógica [...]; mas que são enunciativamente diferentes. Assim, a formulação da relação quantitativa entre os preços e a moeda em circulação pode ser efetivada com as mesmas palavras - ou palavras sinônimas - e ser obtida pelo mesmo raciocínio; ela não é enunciativamente idêntica em Gresham ou Locke e nos marginalistas do século XIX; não pertence, em nenhum caso, ao mesmo sistema de formação dos objetos e dos conceitos ${ }^{174}$.

Por fim, insiste o filósofo, o enunciado tampouco equivale a um speech act ${ }^{175}$, um ato de formulação ou ato ilocutório ${ }^{176}$. Segundo Foucault, com este termo, os analistas ingleses designam

\footnotetext{
${ }^{171}$ Foucault, A arqueologia do saber, p. 32.

172 Idem, p. 91.

173 Idem, p. 93.

${ }^{174}$ Idem, p. 164.

${ }^{175}$ Foucault se refere aqui provavelmente a John Austin que publica em 1962 Quando dizer é fazer.

176 Foucault traduz a expressão inglesa speech act por "acte illocutoire" e "acte de formulation" (cf. Foucault, L'archeologie du savoire, p. 114). A tradução brasileira segue à risca Foucault e traduz os termos por "ato ilocutório" e "ato de formulação".
} 
o ato que se produziu com a enunciação de "promessa, ordem, decreto, contrato, compromisso, constatação"177. Apesar de considerar verossímil a aproximação entre sua noção de enunciado e a de speech act, para Foucault os dois conceitos não equivalem, já que para formar um ato de linguagem é necessário mais de um enunciado ${ }^{178}$. É o que diz o filósofo:

quando ser quer individualizar os enunciados, não se pode admitir sem reservas nenhum dos modelos tomados de empréstimo à gramática, à lógica ou à "análise" [...]: encontramos enunciados sem estrutura proposicional legítima; encontramos enunciados onde não se pode reconhecer nenhuma frase; encontramos mais enunciados do que os speech act que podemos isolar ${ }^{179}$.

E como se não bastasse negar essas três possíveis definições de enunciado, Foucault continua a recusar outras possibilidades de compreensão: o enunciado não é simplesmente uma justaposição de signos seja qual for a sua regra de significação. É certo que para haver enunciado é necessário haver um conjunto de signos linguísticos; porém, não é isso que define sua especificidade. Ele não pode se confundir com a língua, que em função de suas regras de utilização produz frases, proposições ou atos ilocutórios. Tomemos um exemplo de Foucault: o teclado de uma máquina de escrever é composto de letras do alfabeto, isto é, de signos que pertencem a uma língua. Tais letras, porém, não são um enunciado. Diferente é o caso, contudo, da série de letras $A$, $Z, E, R, T$ enumeradas num manual francês de datilografia. Essa série de signos linguísticos, de letras, é um enunciado na medida em que designa "a ordem alfabética adotada pelas máquinas francesas" 180 . Ou seja, tem-se enunciado quando os signos de uma língua são articulados numa certa ordem (que não é necessariamente a da palavra, a da frase ou da proposição), num determinado momento temporal, num lugar específico, por um gesto particular; quando ser referem a um objeto específico, a um sujeito que o apreende de modo singular, quando implica certos conceitos e opta por determinado tema. E, aqui, Foucault parece chegar a uma definição mais positiva, mas não menos desconcertante, do enunciado: "função de existência que pertence, exclusivamente, aos signos" 181 . Mas como, afinal, compreender o enunciado como uma função de existência dos signos?

Ora, quando Foucault nega que o enunciado seja uma frase, uma proposição, uma palavra ou qualquer outro signo ou ato linguístico, ele está recusando dar ao enunciado o caráter de unidade que possuem tais elementos. O enunciado não se confunde com as unidades da língua, da

\footnotetext{
177 Foucault, A arqueologia do saber, pp. 93-4.

178 A relação entre Foucault e a filosofia analítica inglesa tem sido tema de bastante discussão. Cf., por exemplo Gros e Davidson, Foucault, Wittgenstein: de possibles rencontres.

179 Foucault, A arqueologia do saber, pp. 94-5.

180 Idem, p. 97.

${ }^{181}$ Idem, p. 98.
} 
gramática, da lógica ou do ato ilocutório. Ele consiste naquilo que condiciona a existência de tais unidades. Trata-se, assim, explica Foucault, “de uma função que se exerce verticalmente, em relação às unidades" $" 182$.

O enunciado, portanto, diz respeito ao modo de existência daquilo que foi dito, das performances verbais ou linguísticas realizadas. Ou seja, diz respeito ao modo de existência de um conjunto de signos efetivamente produzidos por meio de uma formulação (ato ilocutório), de determinados signos de uma língua e respeitando determinadas regras gramaticais e lógicas. Foucault, então, conclui: "Chamaremos enunciados a modalidade de existência própria desse conjunto de signos" ${ }^{\prime 183}$.

Ao que tudo indica, poderíamos, então, dizer que o enunciado não diz respeito propriamente às estruturas internas da língua (seus signos, suas regras e seus atos) mas àquilo que lhe é exterior $^{184}$. E, aqui, voltamos ao que dizíamos acima: o enunciado diz respeito a práticas que produzem os objetos disponíveis para serem designados por um signo, uma palavra, uma frase etc (os modos de objetivação); a práticas que indicam as posições possíveis que os sujeitos podem assumir a fim de dizer o que dizem (os modos de subjetivação); a um campo de diferentes conceitos dos quais pode se utilizar; e, por fim, a uma série de estratégias temáticas possíveis pelas quais pode optar. Porém, aqui é mais uma vez necessário fazer uma advertência: que não se tome somente um desses elementos externos à língua ou à linguagem como sua condição de existência. O enunciado, para Foucault, não é nem o objeto designado por uma fala ou escrita (o significado), nem o sujeito que a enuncia, nem os conceitos que ela utiliza, nem as opções temáticas a ela disponíveis, mas sim a coexistência de todos esses elementos. Interessa-lhe, pois, compreender de que modo tudo isto se articula numa trama ou sistema, que Foucault chama, como vimos, de formação discursiva ${ }^{185}$.

As condições de existência de uma fala que se referem ao domínio possível dos objetos designados, do sujeito da enunciação, dos conceitos utilizados e das estratégias escolhidas, são

\footnotetext{
182 Foucault, A arqueologia do saber, p. 98.

${ }^{183}$ Idem, p. 121.

184 Cf. por exemplo: "Ele [o nível enunciativo] define a modalidade de seu aparecimento [da linguagem efetiva]: antes sua periferia que sua organização interna, antes sua superfície que seu conteúdo" (Foucault, A arqueologia do saber, p. 127). Cf. ainda A ordem do discurso, p. 53, onde Foucault fala em "condições exteriores de possibilidades".

185 Cf. Foucault, A arqueologia do saber, p. 132: “a formação discursiva se caracteriza não por princípios de construção, mas por uma dispersão de fato, já que ela é para os enunciados não uma condição de possibilidade, mas uma lei de coexistência".
} 
também chamadas por Foucault de positividades ${ }^{186}$. O sistema de positividade de um discurso ou de um pensamento (lembremos aqui que Foucault inaugura uma cadeira no Collège de France intitulada "História dos sistemas de pensamento") como o da história natural, da economia política, da filologia ou da medicina clínica, diria respeito, portanto, ao sistema de regras que faz coexistir diferentes condições de existência de seus enunciados. Confirma o filósofo: "Analisar positividades é mostrar segundo que regras uma prática discursiva pode formar grupos de objetos, conjuntos de enunciações, jogos de conceitos, séries de escolhas teóricas"187. As positividades podem, então, serem entendidas como aquilo que funciona como o a priori histórico daquilo que foi dito. É esse sistema de positividade ou esse a priori histórico que, por exemplo, explica Foucault, permite dizer que Buffon e Lineu falavam do mesmo objeto, colocavam-se do mesmo modo como sujeitos de suas enunciações, utilizavam a mesma rede conceitual e situavam-se no mesmo campo de batalha teórica $^{188}$.

Assim, se de alguma maneira a análise do enunciado pode ser considerada uma análise da linguagem, que fique claro que não se trata de interrogar a linguagem em suas condições transcendentais e formais de possibilidade, interrogar-se pela língua que a antecede ou pelo sujeito constituinte que logicamente a possibilita. Ou seja, não se trata de um questionamento fundacionista e transcendental. Mas tampouco se trata de um questionamento interpretativo e antropológico da linguagem, que se pergunta por suas significações, pelo seu referente, isto é, que toma a linguagem em seu poder de designar, de nomear, mostrar, de fazer aparecer, "de ser o lugar do sentido ou da verdade" e da expressão de um sujeito psicológico ${ }^{189}$. Esclarece Foucault:

A análise enunciativa é, pois, uma análise histórica, mas que se mantém fora de qualquer interpretação: às coisas ditas, não pergunta o que escondem, o que nelas estava dito e não-dito que involuntariamente recobrem, a abundância de pensamentos, imagens ou fantasmas que as habitam ${ }^{190}$.

A análise da linguagem em Foucault é, pois, um questionamento que se pergunta pelo regime de sua facticidade. Sendo assim, não é nem um questionamento transcendental, nem antropológico $^{191}$; quer compreender as condições de existência da linguagem enquanto dado já

\footnotetext{
186 Cf., por exemplo, Foucault, A arqueologia do saber, p. 142 e p. 234. A nosso ver, positividade é outro nome que Foucault dá à formação discursiva ou ao saber. Todos esses termos, no nosso entender, dizem respeito às condições de existência ou ao a priori histórico dos enunciados, ou seja, ao sistema ordenado de práticas discursivas e não discursivas que os produz.

${ }^{187}$ Foucault, A arqueologia do saber, p. 203.

${ }^{188}$ Cf. Foucault, A arqueologia do saber, p. 143.

${ }^{189}$ Cf. Foucault, A arqueologia do saber, p. 154.

${ }^{190}$ Foucault, A arqueologia do saber, pp. 124 e ssg.

${ }^{191}$ Cf. Foucault, A arqueologia do saber, p. 128: “A linguagem, na instância de seu aparecimento e de seu modo de ser, é o enunciado; como tal, se apoia em uma descrição que não é nem transcendental, nem antropológica”.
} 
existente, um já-lá, "na instância de seu aparecimento e de seu modo de ser"192. Para tanto, deve descrever tais condições como sistema que articula práticas que produzem objetos, sujeitos, conceitos e estratégias. É, portanto, a lei da coexistência dessas práticas que configuram atual e efetivamente o uso que fazemos dos signos linguísticos que cabe à arqueologia de Foucault investigar. Nesse sentido, assegura Foucault, cabe ao arqueólogo "referir o discurso não ao pensamento e ao espírito do sujeito que lhe possibilitou o nascimento, mas ao campo prático no interior do qual ele se dá"193. O domínio da arqueologia, portanto, é delimitado não só por aquilo que foi dito, mas pela regra de coexistência de todas as diferentes práticas que possibilitaram essa realização. A nosso ver, é a noção de prática discursiva que parece melhor designar o que seja um enunciado, já que a ideia de prática nos alerta tanto para o fato do enunciado ser alguma coisa que foi praticada (ele é um dito, um algo falado ou escrito, signos linguísticos utilizados e efetivados) quanto de ser alguma coisa que foi praticada de determinada maneira (isto é, que existe em obediência a certas regras) ${ }^{194}$. É, pois, com a noção de prática discursiva que Foucault defende a tese de que "falar é fazer alguma coisa"195. E insistamos: para Foucault, falar é fazer alguma coisa não somente no sentido em que ela consiste na ação ou no gesto de falar, porque ela consiste na ação subjetiva "de exprimir o que se pensa, de traduzir o que se sabe e, também, de colocar em ação as estruturas de uma língua"196. Para o filósofo, falar é fazer alguma coisa principalmente na medida em que é um gesto "complicado e custoso" que implica uma série de práticas que não são só linguísticas ${ }^{197}$.

O que exatamente se faz quando se fala?

Em primeiro lugar, se produzem objetos: toda fala, todo uso de signos linguísticos, implica um recorte da realidade e das coisas, recorte que define o objeto de que se fala, que define a estrutura visível daquilo de que se fala. Nesse sentido, diz Foucault, a arqueologia deve "definir o

\footnotetext{
192 Foucault, A arqueologia do saber, p. 128

193 Foucault, "Réponse à une question", in DE I, p. 711.

194 Para os dois aspectos da prática discursiva, o de performance verbal e o de uma maneira regrada de ser, cf. Foucault, A arqueologia do saber, p. 133 e p. 234. No artigo "Foucault" escrito para o Dictionnaire des philosophes, Foucault afirma que entende por prática um "modo de agir e de pensar", uma maneira de fazer "mais ou menos regrada, mais ou menos refletida" (Foucault, "Foucault", in DE II, p. 1454).

195 Foucault, A arqueologia do saber, p. 234.

196 Ibidem.

197 Esse é, pois, o caráter desconcertante de discurso e de enunciado em Foucault. Apesar de se referirem à ordem propriamente discursiva e linguística, eles não se restringem a esse campo. Sobre a prática discursiva, por exemplo, Foucault comenta: "As práticas discursivas não são pura e simplesmente modos de fabricação de discursos. Elas tomam corpo num conjunto de técnicas, em instituições, em esquemas de comportamentos, em tipos de transmissão e de difusão, em formas pedagógicas que a um só tempo as impõem e as mantêm" (Foucault, "Résumé du cours", in Leçons sur La volonté de savoir, p. 218).
} 
regime geral a que obedecem seus objetos, a forma de dispersão que reparte regularmente aquilo de que falam, o sistema de seus referenciais" ${ }^{198}$. E, segundo nosso autor, História da loucura é um livro que se deteve na pesquisa sobre a formação dos objetos, no caso, o objeto loucura: "o problema era a emergência de todo um conjunto de objetos muito enredados e complexos; tratavase de descrever, antes de tudo, a formação desses objetos para demarcar, em sua especificidade, o conjunto do discurso psiquiátrico" 199 . Na década de 80 , Foucault chamará essa produção de objeto de "objetivação", e é da seguinte maneira que ela deve ser investigada: "determinar as condições em que alguma coisa pode tornar-se objeto para um conhecimento possível, como ela pôde ser problematizada como objeto a ser conhecido, a qual procedimento de recorte ela pôde ter sido submetida, a parte dela que foi considerada pertinente"200. No século XIX, por exemplo, o objeto loucura refere-se a um certo conjunto de condutas desviantes; é essa a parte da realidade que foi "recortada" por um certo tipo de olhar ou um certo modo de perceber. E aqui já estamos na segunda dimensão da prática discursiva, a do sujeito de enunciação, aquela que tem a ver com a posição do sujeito que conhece e que certamente é inseparável da dimensão do objeto. Afinal, ensina Foucault, sujeito e objeto se constroem mutuamente ${ }^{201}$.

Falar, então, é também fazer alguma coisa na medida em que supõe certos tipos de comportamentos do sujeito de enunciação, do sujeito que percebe, vê, observa, conhece, descreve, decifra, registra, decide. Ou seja, o falar implica não só a formação de um certo tipo de objeto, mas também de certo tipo de sujeito. Nesse contexto, a tarefa da arqueologia é definir "o regime geral ao qual obedecem os diferentes modos de enunciação, a distribuição possível das posições subjetivas e o sistema que os define e os prescreve" ${ }^{202}$. E no mesmo texto da década de 80 citado acima, Foucault explica como se deve investigar os "modos de subjetivação" ou os "modos de enunciação":

a questão é determinar o que deve ser o sujeito, a que condição ele está submetido, qual estatuto ele deve ter, qual posição ele deve ocupar na realidade ou no imaginário a fim de tornar-se sujeito legítimo deste ou daquele tipo de conhecimento [...] pois este evidentemente não é o mesmo se o conhecimento de que ele trata tem a forma da exegese de um texto sagrado, de uma observação de história natural ou da análise do comportamento de um doente mental ${ }^{203}$.

\footnotetext{
198 Foucault, A arqueologia do saber, p. 131.

199 Idem, p. 72.

${ }^{200}$ Foucault, "Foucault", in DE II, p. 1451.

201 No artigo do Dictionnaire des philosophes, Foucault explica que seu interesse sempre fora o de mostrar que a formação dos objetos e dos sujeitos não são independentes, mas antes, que se constrõem mutuamente. Cf. "Foucault", in DE II, p. 1451.
}

202 Foucault, A arqueologia do saber, p. 131.

203 "Foucault", in DE II, p. 1451. 
De acordo com Foucault, $O$ nascimento da clínica tinha como meta pesquisar a maneira pela qual se modificaram, no fim do século XVIII e início do século XIX, as formas de enunciação do discurso médico. Nesse contexto, afirma Foucault: "a análise, então, havia se voltado menos para a formação dos sistemas conceituais, ou para a das escolhas teóricas, do que para o status, o lugar institucional, a situação e os modos de inserção do sujeito falante"204.

Por fim, a análise dos usos linguísticos, em Foucault, a arqueologia, deve ainda levar em consideração que se faz com os conceitos e com os temas quando se constrói um discurso. Canguilhem teria dado um bom exemplo de como se pôde fazer diferentes usos do conceito de reflexo na ciência clássica e na moderna, ou ainda, como o conceito de organismo aparece de modo diferente antes e depois da biologia ${ }^{205}$. Além disso, Foucault esclarece que num livro como $A s$ palavras e as coisas seu objetivo principal fora justamente o de demarcar as redes de conceitos e as suas regras de formação no interior da gramática geral, da história natural e da análise das riquezas. Finalmente, no que tange às escolhas temáticas que determinam a maneira como a apropriação de um mesmo discurso depende de diferentes interesses e estratégias, nosso autor confessa que, pelo menos até 1969, tinha se dedicado pouco à questão, mas que a oposição entre fixistas e evolucionistas, entre fisiocratas e utilitaristas indicada em As palavras e as coisas, davamindicativos de uma pesquisa que se ocupa com as oposições teóricas e com as opções de escolhas estratégicas ${ }^{206}$.

Visto, então, em que medida a análise discursiva de Foucault diz respeito a uma série de práticas em torno do uso efetivo que damos aos signos linguísticos, voltemos às possíveis vizinhanças entre a antropologia kantiana e a arqueologia foucaultiana a fim de dar alguns desdobramentos a esse caráter empírico e pragmático das análises discursivas de Foucault.

Antropologia pragmática e arqueologia: das condições de validade às condições de existência

Sabemos já que Kant, na Antropologia pragmática, se dirige à experiência já-dada. Não lhe cabe tanto ali interrogar pelas condições de possibilidade da experiência, mas de descrevê-la em sua facticidade. As faculdades da mente (as faculdades de conhecer, de desejar e o sentimento de prazer e desprazer) não são descritas enquanto transcendentais, mas descritas em seu uso concreto. E é por

\footnotetext{
${ }^{204}$ Foucault, A arqueologia do saber, p. 72.

205 Cf. Foucault, A arqueologia do saber, p. 195.

${ }^{206}$ Cf. Foucault, A arqueologia do saber, p.72.
} 
isso, conforme vimos, que a antropologia kantiana não é um questionamento transcendental, mas uma investigação empírica e pragmática. De modo semelhante, o método de Foucault volta-se para a linguagem não para compreender suas condições transcendentais ou antropológicas de possibilidade. Acabamos de ver que, como na antropologia de Kant, o que interessa a Foucault é o já-dado, é a linguagem em sua facticidade, a linguagem já efetivada, o que já foi dito. Nesse sentido, a arqueologia não é um método transcendental, mas empírico e também pragmático, já que se pergunta pelo que se $f e z$ no campo da linguagem, pela série de práticas que acompanham certos usos dos signos linguísticos.

A “filosofia pragmática” de Foucault, contudo, não é idêntica àquela de Kant. Vimos, pois, que o que interessa ao filósofo alemão em sua Antropologia é o uso concreto das faculdades da mente, o que se faz concretamente, por exemplo, com a percepção, a imaginação, o desejo ou mesmo com o sentimento de prazer e desprazer. Seguramente não é esse mesmo tipo de uso que estará em questão em Foucault. Como indicamos, para o filósofo francês trata-se de descrever os usos da linguagem; não os usos da faculdades mentais ligadas à linguagem, mas os usos que se fazem dos signos linguísticos a partir de quatro dimensões diferentes: a do sujeito, a do objeto, a dos conceitos e a das estratégias temáticas. Mas, como exatamente compreender esse uso que não é o uso da antropologia kantiana? Será que o uso da linguagem, em Foucault, ainda diz respeito à facticidade e efetividade de uma relação entre empírico e transcendental?

Pode-se dizer que, de certo modo, a "antropologia pragmática" de Foucault esbarra também na questão da relação entre o fato e as suas condições. Tal problemática, contudo, não poderá ser compreendida exatamente nos mesmos termos que a relação entre empírico e transcendental em Kant. Como dissemos, não se trata, por exemplo, de pensar o uso da linguagem como a efetividade de capacidades linguísticas transcendentais do sujeito e o dizer numa determinada língua. Insistimos já que não é o caso de dizer que Foucault nega a existência do sujeito transcendental, porém, não é esse aspecto da realidade que o interessa. E lembremos também que, para Foucault, não é a língua a condição de existência daquilo que é dito. Não é nesse contexto que o uso da linguagem, como efetividade de certas condições, deve ser compreendido. Indicamos já que a Foucault interessam as condições concretas de existência dos usos e não as condições formais de possibilidade destes.

Assim, se, por um lado, a antropologia pragmática de Kant não deixa de ser uma repetição da Crítica, uma vez que a descrição empírica dos usos concretos das faculdades da mente pressupõe suas condições transcendentais de possibilidade, por outro lado, a "antropologia pragmática" de Foucault, que descreve os usos da linguagem (o que foi dito), não existe sem uma referência às 
condições desses usos. Porém, é só num sentido aproximativo que as condições de existência dos enunciados podem ser entendidas como transcendentais. Talvez seja melhor preferir o termo foucaultiano "quase-transcendental", pois se as condições de existência dos enunciados funcionam como condições de possibilidade destes, elas não dizem respeito a condições formais que possibilitam a experiência, o conhecimento ou o uso, em geral, de nossas faculdades, mas a condições concretas que possibilitam a existência ou a realidade de um saber ou de um discurso singular. Nas palavras de Foucault, elas não são "condições de validade para juízos, mas condição de realidade para enunciados"207. O a priori de Foucault não é formal, mas uma figura "puramente empírica" e concreta; é aquilo mesmo que, nas palavras do filósofo, "permite compreender como os a priori formais podem ter na história pontos de junção, lugares de inserção, de irrupção ou de emergência, domínios ou ocasião de utilização"208. Por fim, conclui Foucault: "o a priori formal e o a priori histórico não são nem do mesmo nível nem da mesma natureza" ${ }^{209}$. O primeiro é atemporal, o segundo só pode ser pensado do tempo. Retomando os termos da "Introdução à Antropologia”: o primeiro diz respeito ao nível do fundamental, o segundo, ao nível do originário.

Vê-se, aqui, uma espécie de inversão da empresa kantiana. Em vez de se buscar o que possibilita a unidade sintética do conhecimento no nível do fundamental, do formal e do subjetivo (o sujeito transcendental), Foucault procura a unidade do saber, do discurso ou do pensamento, no nível do originário, do concreto e exterior ao sujeito. Mas o filósofo sabe que esse "quasetranscendental" que é da ordem do empírico e do histórico (lembremos, pois, que "a priori histórico" é o outro nome que Foucault dá às condições de existência ou a esse "quasetranscendental") não pode ser confundido com o transcendental propriamente dito; sabe, portanto, que não se pode tomar as condições concretas de existência de um discurso, condições de singularidade, como condições de possibilidades de todo e qualquer discurso, condições de universalidade; sabe, por fim, que não se pode confundir aquilo que é da ordem do conhecimento empírico e singular, condição de realidade, com o que é da ordem do conhecimento transcendental e universal, condição de validade.

Mas, se o a priori histórico de Foucault, esse quase-transcendental, é da ordem do empírico, a investigação foucaultiana não se situa no mesmo domínio que o das analíticas da finitude? Ao se perguntar pelas condições concretas de existência, o filósofo não corre o risco de cair nas

\footnotetext{
${ }^{207}$ Foucaultl, A arqueologia do saber, p. 144, grifo nosso.

208 Idem, p. 145.

${ }^{209}$ Idem, pp. 145-6.
} 
contradições decorrentes da confusão entre empírico e transcendental? Como, afinal, nosso autor se diferencia desses tipos de reflexão se, ele também, parece dar ao empírico um certo estatuto de transcendental?

Ora, para responder a esta questão é necessário lembrar que o grande erro das analíticas da finitude foi precisamente o de ter tomado os "quase-transcendentais" da língua (a fala), da vida (o corpo) e do trabalho (o desejo), como propriamente transcendentais, ou seja, como condições formais e universais de possibilidades do ser finito, e não simplesmente como condições concretas e singulares de sua existência. O problema das analíticas da finitude foi pretender conhecer empiricamente a finitude radical do homem, pretender conhecer empiricamente alguma coisa que só seria possível ser conhecida transcendentalmente. Ou seja, o deslize das analíticas da finitude foi similar ao deslize das metafísicas pré-kantianas: elas não respeitaram os limites de nosso conhecimento ao pretender conhecer objetos (no caso, o ser finito do homem) que estão além da experiência sensível.

Diferentemente das analíticas da finitude, Foucault não tem a intenção de dar propriamente estatuto de transcendental àquilo que conhece empiricamente. Ele não desloca, como elas, as estruturas a priori "em direção a um começo, em direção a um arcaico de fato ou de direito", mas sim, como Kant na Antropologia, "a uma dimensão verdadeiramente temporal"210. O "quasetranscendental" de Foucault não diz respeito a nada que possa ser tomado como fundamento absoluto do homem, mas se refere somente àquilo que garante sua existência singular. Ao se perguntar pelas condições de existência do que foi dito, o filósofo francês parece fazer, portanto, um uso absolutamente legítimo da razão, um uso empírico dentro dos limites da experiência sensível, mantendo-se, por conseguinte, fiel à lição kantiana que distingue o empírico do transcendental. E aqui cabe explicar o termo arqueologia. Diz Foucault: "Esse termo não incita à busca de nenhum começo; não associa a análise a nenhuma sondagem geológica. Ele designa o tema geral de uma descrição que interroga o já dito no nível de sua existência" ${ }^{211}$. A arqueologia, assim, não é um método que nos permite encontrar fundamentos, mas apenas fazer diagnósticos ${ }^{212}$.

Mas, se é assim, se a empreitada de Foucault é absolutamente empírica, o que a diferencia das ciências empíricas propriamente ditas? Se ele se preocupa em conhecer e descrever somente as empiricidades (lembremos que ele é um confesso “positivista feliz"!213), como se distingue das

\footnotetext{
${ }^{210}$ Foucault, "Introduction à l'Anthropologie”, p. 58.

${ }^{211}$ Foucault, A arqueologia do saber, p. 149.

${ }^{212}$ Cf. Foucault, A arqueologia do saber, p. 230.

${ }^{213}$ Cf. Foucault, A arqueologia do saber, p. 142.
} 
ciências como a biologia, a economia ou a linguística que têm como objeto os "quasetranscendentais" da vida, do trabalho e da língua? Será que a única diferença está no objeto, não mais a língua, a vida ou o trabalho, mas as condições de existência do discurso, as práticas que produzem sujeitos, objetos, conceitos e opções teóricas, e que condicionam os usos dos signos linguísticos?

A meu ver, apesar do caráter empírico da filosofia de Foucault, ela não se confunde com uma ciência empírica. E isso pelo mesmo motivo que a antropologia pragmática de Kant não se confundia com uma antropologia fisiológica. Vimos, pois, que, para Kant, o que diferencia uma antropologia do ponto de vista físiológico e outra do ponto de vista pragmático é que enquanto a primeira se interessa pelo que a natureza fez do homem, a segunda se ocupa com o que o homem pode e deve fazer de si mesmo. É pela mesma direção que Foucault se afasta de uma ciência empírica. Sua pesquisa não se interessa pelo o que homem faz enquanto é determinado por uma tipo de vida, um modo de produção e uma língua que lhe são anteriores. E mesmo que nosso autor trate de certo modo da linguagem, seu objeto não é a língua, mas o modo como os próprios homens fazem uso dos signos de uma língua. Usando os termos da antropologia kantiana: não interessa a Foucault mostrar como os homens são "jogados” por uma língua ou por uma estrutura subjetiva que possibilita em geral a linguagem, mas como eles mesmos “jogam” com uma língua dada; como eles jogam com ela quando constroem discursos, isto é, quando constroem objetos enunciados, sujeitos de enunciação, conceitos e teorias. No entanto, se, em Kant, a distância entre o que a natureza faz dos homens e o que eles fazem de si mesmos, entre uma ciência empírica (a físiologia) e a antropologia pragmática, é dada pela liberdade, ainda é preciso averiguar se acontece o mesmo em nosso autor.

A relação entre determinação e liberdade seguramente é um problema que permeia toda a obra de Foucault. Em seus primeiros escritos o tema ainda não aparece de modo explícito. Entretanto, ao passo que a pesquisa arqueológica vai se desenvolvendo, Foucault parece perceber que não é mais possível contornar a espinhosa questão. Mas por que espinhosa questão?

Ora, dizíamos acima, retomando passagens de $A$ arqueologia do saber, que ao pensar o que foi dito, Foucault recusa todos os operadores de sínteses que sejam puramente subjetivos (sujeito transcendental ou psicológico). Vimos, pois, que nosso autor procura no domínio empírico e exterior ao sujeito as condições que possibilitam a existência concreta de um enunciado particular. Ou seja, procura no domínio do empírico e exterior ao sujeito os operadores de sínteses que possibilitam certos usos dos signos linguísticos, que possibilitam que algo seja enunciado e que tenha sentido. Mas, se é assim, se Foucault "coloca entre parênteses" os operadores subjetivos de 
sínteses, em que sentido podemos compreender que sua antropologia diz respeito, ela também, à liberdade? Esta instância do que o homem faz de si mesmo, a instância do uso, não nos remete necessariamente ao sujeito transcendental, àquele que pode e deve agir livremente sobre si mesmo? Se assim for, Habermas não teria razão, então, em dizer que, em última instância, Foucault cai em contradição performativa, já que nega o sujeito transcendental, mas que, ao mesmo tempo, conta com ele como condição para fazer certo uso da linguagem e construir seu próprio discurso?

Ora, já insistimos na ideia de que Foucault não nega a existência do sujeito enquanto realizador de sínteses, de significado e enquanto condição de possibilidade necessária para a realização do discurso; o que ele nega é que esse sujeito seja soberano e que tenha direito exclusivo sobre o discurso. Como vimos, Foucault isola o sujeito transcendental a fim de considerar outras condições, também necessárias, para que um discurso exista, não de maneira geral, mas de modo singular; ele "põe entre parênteses" as condições de possibilidade universalizantes (as condições de validade), e centra-se nas condições de possibilidade singularizantes (as condições de existência ou de realidade). A mesma coisa pode ser dita acerca da possibilidade da ação livre.

A nosso ver, não caberá a Foucault recorrer à instância subjetiva e transcendental do homem a fim de compreender o princípio causal dos usos. As condições de possibilidade universais e gerais da ação serão deixadas de lado em benefício de considerações que procurem condições concretas e singulares que expliquem o aparecimento de nossas ações. O que interessa a Foucault, portanto, no que tange às ações relativas ao que fazemos de nós mesmos, não é tanto investigar as condições que, de direito, possibilitam essa ação, mas as condições que, de fato, a efetivaram e as condições que, de fato, possibilitam que ela seja mudada. Isso significa que é no interior mesmo do campo empírico e histórico que Foucault investigará as possibilidades de liberdade. E do mesmo modo que chamamos o campo empírico das condições de existência dos usos de quase-transcendental, uma vez que não dizem respeito propriamente a condições de possibilidades subjetivas e transcendentais, as condições concretas de liberdade buscada por Foucault a fim de justificar a possibilidade de fazermos um uso livre da linguagem, devem também ser compreendidas como uma quaseliberdade, uma vez que elas também não se referem a nenhuma espécie de liberdade subjetiva, seja ela transcendental ou psicológica.

Aqui, então, a inversão do esquema kantiano parece ser total. Vimos que, em ao menos dois sentidos diferentes, podia-se dizer que a antropologia pragmática de Kant é uma repetição da Crítica, isto é, que é uma investigação empírica que recorre ao transcendental. Em primeiro lugar, na medida em que é uma descrição dos usos concretos das faculdades da mente, a Antropologia pragmática pressupõe a Crítica da Razão Pura que descreve transcendentalmente tais faculdades 
em seu estado puro. Neste contexto, a antropologia kantiana nada mais faz do que descrever uma experiência real, ou seja, uma interação efetiva entre as condições transcendentais de possibilidade da experiência em geral (transcendental) e as condições empíricas desta, os dados sensíveis (empírico). Em segundo lugar, a antropologia pragmática é também uma repetição da Crítica da Razão Prática, já que conta com a liberdade transcendental do sujeito. Neste âmbito, os usos empíricos das faculdades mentais que interessam à antropologia são aqueles guiados pelo sujeito livre, pelo sujeito que, em observância às leis da razão, age tendo em vista o bem da humanidade.

Antes de tudo, vale lembrar que a "antropologia pragmática" de Foucault se interessa pela experiência efetiva no campo da linguagem; interessa-lhe o que foi dito. Porém, contrariamente a Kant que se pergunta mais pelas condições subjetivas de possibilidade, pondo entre parênteses, digamos assim, por meio da crítica, as condições objetivas e sensíveis de possibilidade, Foucault irá interessar-se mais justamente por este último tipo de condição. Nesse sentido, a empresa crítica de Foucault é o inverso da kantiana. Enquanto o filósofo alemão isola o sujeito transcendental pondo entre parênteses os dados sensíveis da experiência, Foucault isola o campo das condições empíricas desta e coloca entre parêntese o próprio sujeito transcendental. Assim, da perspectiva de Foucault, para se compreender uma determinada experiência efetiva da linguagem, certo uso da linguagem, um dito, não é necessário o recurso a uma crítica que nos dê as condições subjetivas de possibilidade dessa experiência, mas a uma reflexão que nos forneça as condições objetivas e concretas que possibilitaram a existência da experiência. E, no interior da investigação empírica sobre o discurso, o recurso às condições empíricas de possibilidade deve ser compreendido em dois sentidos diferentes. Em primeiro lugar, para se compreender o que foi dito, é preciso conhecer suas condições de existência. Em segundo lugar, interessa também a Foucault investigar quais as condições concretas de liberdade que o indivíduo teve ou não teve para falar aquilo que falou e para deixar de falar o que não falou.

Assim, se é verdade que a "antropologia pragmática" de Foucault não consiste simplesmente numa descrição empírica daquilo que em nós é determinado por algo que nos escapa, mas que se interessa, assim como a antropologia kantiana, pelo fazemos de nós mesmos, é preciso, então, compreender o sentido exato da liberdade que está em jogo, em Foucault, nesse âmbito do uso, nesse domínio em que agimos sobre nós mesmos. Para tanto, Kant não nos servirá mais como guia, afinal, a liberdade em questão na Antrpologia de um ponto de vista pragmático diz respeito à liberdade de um sujeito puro que tem no dever moral postulado pela razão o norte de sua ação. A partir de então, é Nietzsche, com seu método genealógico e com sua teoria do poder, que oferecerá a Foucault um modelo de reflexão que seja capaz de justificar o aparecimento de nossas ações sem 
recorrer a uma teoria do sujeito. Mas antes de adentrarmos no mundo nietzschiano de Foucault, vejamos um pouco mais de perto por que o método arqueológico não dá conta sozinho de uma teoria da ação.

\section{O problema da liberdade na passagem da arqueologia à genealogia}

A nosso ver, é somente com a passagem do método arqueológico ao método genealógico que Foucault investiga as possibilidades de uma liberdade efetiva, isto é, as possibilidades de, de fato, termos certa liberdade em nossos usos. O filósofo parece confirmar essa ideia em um artigo intitulado “Qu'est-ce que les Lumières?”, de 1984. Neste texto, Foucault define a arqueologia como método não transcendental que trata dos discursos que articulam o que pensamos, dizemos e fazemos; à genealogia, por outro lado, não cabe deduzir da forma daquilo que somos o que nos é impossível fazer e conhecer, mas "tirar da contingência do que nos fez ser o que somos a possibilidade de não mais sermos, fazermos ou pensarmos o que somos, fazemos ou pensamos. [...] ela procura lançar o mais longe e o mais amplamente possível o trabalho indefinido da liberdade" 214 .

Assim, se a arqueologia ocupou-se com as condições concretas de existência do discurso, ao que tudo indica, a genealogia deverá indagar as condições concretas de liberdade que nos permitem agir sobre as determinações históricas. E que se note que a importância dessa passagem metodológica não se deve simplesmente ao fato de Foucault pretender abordar um novo objeto. A nosso ver, a pesquisa genealógica responde a um limite bem preciso e de certo modo às dificuldades que se podiam pressentir desde os trabalhos arqueológicos. Que limites e que dificuldades são essas? O limite metodológico da arqueologia em não tratar do tema da origem, isto é, daquilo que explica a causalidade do discurso, ou seja, o seu aparecimento, sua transformação e seu perecimento. É o próprio Foucault quem restringe o domínio da investigação arqueológica: “Arqueologia - eu a empreguei como jogo de palavras para designar alguma coisa que seria a descrição do arquivo e de modo algum a descoberta de um começo ou a 'remise au jour des ossements' do passado"215.

Vimos já que em $A$ arqueologia do saber Foucault deixa de lado a instância subjetiva, psicológica ou transcendental, para explicar o surgimento dos usos que damos à linguagem. Ou seja, ele não recorre ao sujeito como instância fundadora e causal do discurso. Mas, no mesmo

\footnotetext{
${ }^{214}$ Foucault, “Qu'est-ce que les Lumières?”, in DE II, p. 1393.

${ }^{215}$ Foucault, "La naissance d'un monde", in DE I, pp. 814-5.
} 
livro, Foucault ainda deixa de lado ao menos outras duas supostas vias possíveis para se compreender a origem do discurso. Duas possíveis vias que, por meio de uma filosofia da história, digamos assim, talvez pudesse dar conta de uma teoria da ação, isto é, dar conta de justificar donde surgem nossas ações.

Primeiramente, poderíamos pensar que as causas e as origens de um discurso teriam sido tematizadas por Foucault por meio da descrição das práticas não discursivas (aquelas que não pertencem ao campo discursivo propriamente dito, mas ao campo institucional, econômico, social e político). No que tange ao discurso psiquiátrico do século XIX, por exemplo, poderíamos pensar que sua origem se deve a todas as práticas institucionais, a todas as decisões políticas, a todos os processos econômicos que envolveram mudanças demográficas, técnicas assistenciais, que estiveram em voga no período ${ }^{216}$. Porém, insiste Foucault, sua intenção ao descrever as práticas não discursivas não era encontrar os mecanismos de causalidade existentes entre a ordem discursiva e a não discursiva, mas antes, a lei de sua coexistência, o princípio de sua articulação. Diz Foucault:

Diante de um conjunto de fatos enunciativos, a arqueologia não se questiona o que pôde motivá-lo (esta é a pesquisa dos contextos de formulação) [...] ela tenta determinar como as regras de formação de que depende - e que caracterizam a positividade a que pertence - podem estar ligadas a sistemas não discursivos: procura definir formas específicas de articulação ${ }^{217}$.

Não que a arqueologia negue que certas práticas de uma ordem podem ser a causa de práticas de outra ordem. O que ela nega é encontrar em uma única prática a causa da transformação de todo um domínio; nega que a história seja constituída por meio de um sistema simples de causa e efeito e, no lugar da causalidade, prefere as relações de implicação, exclusão e transformação ${ }^{218}$.

Numa entrevista de 1969 para o Le Monde, Foucault deixa claro que é oposto a uma forma de história que considera a mudança como um dado e que se coloca como tarefa encontrar sua causa. Segundo ele, o historiador deveria ser mais modesto e, ao invés de pretender encontrar $a$ causa da transformação, deveria se preocupar em compreender no que consistiu exatamente a mudança, quais são seus diferentes níveis, quais foram as modificações mais visíveis e as menos visíveis $^{219}$.

\footnotetext{
${ }^{216}$ Cf. Foucault, A arqueologia do saber, p. 177.

${ }^{217}$ Foucault, A arqueologia do saber, p. 183.

218 Segundo Foucault trata-se, então, de negar a causalidade em termos de racionalidade formal: "há séculos as ciências naturais - e há algumas dezenas de anos as ciências humanas - perceberam que a relação causal é impossível de ser estabelecida e controlada em termos de racionalidade formal: no fundo a causalidade não existe na lógica" (Foucault, “Qui êtes-vous, professeur Foucault?", in DE I, p. 635).
}

${ }^{219}$ Cf. Foucault, "La naissance du monde”, in DE I, p. 814. 
Assim, na esteira de Nietzsche, mais do que uma causa única, Foucault procura inúmeras causas, "múltiplos elementos determinantes"220. Por esse motivo, diz o filósofo numa conferência em 1978, nada é mais estranho à sua análise do que a recusa da causalidade ${ }^{221}$. E aqui podemos retomar um exemplo dado pelo filósofo:

[a arqueologia] não afirma que a cólera de 1832 não tenha sido um acontecimento para a medicina: mostra como o discurso clínico empregava regras tais que todo um domínio de objetos médicos pôde ser, então, reorganizado, que se pôde usar todo um conjunto de métodos de registro e de notação, que se pôde abandonar o conceito de inflamação e liquidar, definitivamente, o velho problema teórico das febres $^{222}$.

Mas se um esquema causal simples não dá conta de explicar o aparecimento do discurso, tampouco as contradições intrínsecas ao próprio discurso explicam seu movimento. De acordo com o filósofo, há contradições em todas as dimensões de uma formação discursiva (no campo dos objetos, das modalidades de enunciação, dos conceitos e dos temas) ${ }^{223}$, porém, mesmo que tais contradições sejam intrínsecas ao próprio discurso elas não funcionam como princípio de historicidade. Afirma ele:

Não basta, de qualquer forma, procurar nelas [nas contradições] a causa do retardamento ou da aceleração da história; não é a partir da forma vazia e geral da oposição que o tempo se introduz na verdade e na idealidade do discurso. Essas oposições são sempre momentos funcionais determinados [...] permitem a determinação de objetos novos, suscitam novas modalidades enunciativas, definem novos conceitos ou modificam o campo de aplicação dos que já existem, mas sem que nada seja modificado no sistema de positividade do discurso ${ }^{224}$.

Para o arqueólogo, as contradições são simplesmente objetos a serem descritos. Trata-se mais de compreender a lei de sua coexistência enquanto princípio de incompatibilidade do que tomá-las como princípio pacificador. À arqueologia cabe descrever "os diferentes espaços de dissensão", indicar o lugar em que se dá a contradição, fazer "aparecer a ramificação da alternativa. Em suma, arremata Foucault: "trata-se de manter o discurso em suas asperezas múltiplas e de

\footnotetext{
${ }^{220}$ Foucault, “Qu'est-ce que la critique?”, p. 51

${ }^{221}$ Cf. Foucault, “Qu'est-ce que la critique?”, p. 51.

222 Foucault, A arqueologia do saber, p. 189.

${ }^{223}$ Poderíamos aqui retomar o exemplo da história natural do século XVIII: existe no interior dessa formação discursiva uma oposição entre uma história natural sistemática que defenderia uma tese mais fixista no que diz respeito às espécies e aos gêneros (Lineu) e uma história natural metódica que afirmaria certo "evolucionismo" (Buffon). No que diz respeito aos objetos, a primeira descreveria algumas variáveis das plantas, escolhidas arbitrariamente em função da comodidade taxionômica; a segunda, o aspecto geral da planta, a sua totalidade ou pelo menos suas partes mais importantes. No campo das modalidades de enunciação, a análise sistemática, diz Foucault, trabalha com um código perceptivo e linguístico rigoroso; já na descrição metódica, os códigos são mais livres e as escalas de demarcação oscilam mais. O primeiro tipo de análise possibilita o "fixismo", o segundo permite que se pense o tema da transformação das espécies (Cf. Foucault, A arqueologia do saber, pp. 171-4).
} 
suprimir, em consequência disso, o tema de uma contradição uniformemente perdida e reencontrada, resolvida e sempre renascente, no elemento do logos"225.

Ao se deparar com as contradições, diz o filósofo, a arqueologia não procura suprimi-las, resolvê-las ou conciliá-las a fim de transformá-las em causas ${ }^{226}$. Ou seja, a arqueologia não toma as contradições internas às formações discursivas como princípio de organização do discurso; as contradições não podem ser compreendidas enquanto lei do discurso, lei a partir da qual ele emergiria, ao mesmo tempo, para reduzi-la e superá-la. Com poucas palavras: o discurso não pode ser compreendido como "o caminho de uma contradição a outra" 227 . E se é assim, não é com as análises das contradições que Foucault nos autoriza a encontrar uma via possível para pensarmos o aparecimento, a transformação e o perecimento de um certo uso da linguagrm; não é ela que nos explica como é possível enfrentar o que está dado e fazer começar um novo discurso, uma nova episteme, um novo modo de ser, pensar e agir.

Mas, se nem as análises das práticas não-discursivas, nem as análises das contradições, podem ser compreendidas enquanto reflexões que pensam sobre a origem do discurso, isso significa que a arqueologia foucaultiana mantém-se totalmente alheia a esse problema? Será que Sartre teria razão em dizer que em livros como As palavras e as coisas a história estaria totalmente ausente?228 Creio que não. Desde o período arqueológico o tema do surgimento de uma episteme e a passagem de uma a outra, não parece ser estranho a Foucault. Nesse sentido, não estamos de acordo nem com Sartre, nem com aqueles que escrevem em sua esteira, como Oliver Revault d'Allones, que em seu "Michel Foucault: les mots contre les choses", critica o conceito foucaultiano de episteme denunciando-o como estrutura imóvel, generalista e mesmo ditatorial ${ }^{229}$.

Foucault nota com ironia que, em geral, quem o acusa de ter matado a história são os filósofos e não os próprios historiadores. Sartre, por exemplo, em uma entrevista publicada na revista L'Arc em 1966, dedicada exclusivamente a ele, afirma que os filósofos da geração de então, os chamados estruturalistas, têm em comum a recusa da história. De acordo com o autor de $O$ ser $e$

\footnotetext{
${ }^{225}$ Idem, p. 176.

${ }^{226}$ Cf. Foucault, A arqueologia do saber, p. 171.

${ }^{227}$ Foucault, A arqueologia do saber, 171.

228 Cf. Sartre, “Jean-Paul Sartre répond”.

229 Cf. D'Allones, "Michel Foucault: les mots contre les choses", p. 148. Mais adiante conclui o autor: "Michel Foucault escolhe sistematicamente a coerência, para eliminar a contradição; ele privilegiou arbitrariamente a estrutura em detrimento das transformações; ele descreveu os momentos fixos, e não diz nada sobre as passagens; ele propõe instantaneidades, como disse Sartre, lá onde procuramos movimento; ele pretende fazer historiografia, mas não se preocupa com a historicidade. Resumindo, situando-se deliberadamente fora do pensamento dialético, ele abandona a história, e com ela, bem entendido, a racionalidade" (pp. 149-150).
} 
o nada, para Foucault, assim como para Lévi-Strauss e Althusser, a história não seria feita e modificada pelos homens, mas eles é que seriam absolutamente determinados por ela. Nesse contexto, o trabalho de Foucault seria mais uma geologia que nos mostraria a realidade como um dado, do que uma arqueologia que procuraria retraçar a práxis humana responsável pela construção da civilização e da história ${ }^{230}$.

A resposta de Foucault a Sartre é dupla. Em primeiro lugar, Sartre provavelmente não leu $A s$ palavras e as coisas, pois se tivesse lido teria visto que se trata de um livro basicamente sobre as transformações na história. A comparação entre 3 diferentes tipos de episteme não deixa de ser a indicação de importantes momentos de transformação no modo de pensar e de agir dos homens. Em segundo lugar, o incômodo de Sartre em relação a Foucault e aos demais estruturalistas, antes de passar pela questão da história, toca na questão do sujeito. Para Foucault, a Sartre não agrada a ideia de que o sujeito não seja soberano sobre a história, que não seja absolutamente livre para decidir quando e como construí-la ${ }^{231}$. A esse humanismo, que não passa da encarnação de Deus no homem $^{232}$, e que acredita que a história é decidida pela razão e pela liberdade humana, Foucault, então, contrapõe uma história que é sim construída pelos homens, mas talvez mais por aquilo que os determina inconscientemente, do que por aquilo que lhe é consciente. Assim, quando se trata de analisar uma transformação na história, mais do que procurar a consciência subjetiva que esteve por trás dela, para Foucault trata-se de investigar as múltiplas relações que a determinaram; mais do que a liberdade e o espírito, interessa-lhe o arquivo $^{233}$. Neste sentido, Lacan, mais do que os existencialistas e marxistas, parece ter compreendido Foucault. Enquanto Roger Garaudy, por

\footnotetext{
${ }^{230}$ Depois de Sartre muitos críticos de Foucault retomam essa ideia de que a arqueologia foucaultiana é, antes de tudo, uma genealogia (Cf., por exemplo, os textos de Michel Amiot, de Oliver Revault d'Allones, de Roger Garaudy e de Jean-Claude Margolin publicados entre 1966 e 1967 e editados em Les mots et les choses de Michel Foucault - Regards critiques 1966 - 1968). No período dessa polêmica, ou seja, depois do alvoroço causado pela publicação de As palavras $e$ as coisas, também Canguilhem escreve um artigo sobre o livro de Foucault, onde, além de uma defesa de muitos aspectos da pesquisa de nosso autor, encontramos um precioso esclarecimento acerca dessa disputa arqueologia/ geologia. Segundo Canguilhem, enquanto a geologia conhece sedimentos, as arqueologia conhece monumentos. A metáfora utilizada pelo epistemólogo, e que será aproveitada por Foucault em $A$ arqueologia do saber, esclarece que de modo algum a arqueologia foucaultiana desconsidera a história; os monumentos são justamente um produto da história, diferentemente dos sedimentos que, esses sim, são pura natureza. Canguilhem defende, então, Foucault: "Fazer de Foucault uma espécie de geólogo significa dizer que ele naturaliza a cultura retirando-a da história. Os filhos de Maria do existencialismo podem então o taxar de positivista, injúria suprema" (Canguilhem, "Mort de l'homme ou épuisement du Cogito?", p. 254).

${ }^{231}$ Em 1968, Foucault escreve um artigo para Esprit para responder a algumas perguntas colocadas a ele pela revista. O filósofo volta, então, a comentar o mal-estar que parece ter causado em certos filósofos (leia-se Sartre!) o tema da morte do homem e do anti-humanismo. Foucault, ironicamente, diz reconhecer o mal-estar geral e justifica da seguinte maneira o incômodo: "Eles preferirão negar que o discurso seja uma prática complexa e diferenciada, que obedece a regras e a transformações analisáveis, ao invés de serem privados dessa doce certeza, tão consoladora, de poder mudar, talvez não o mundo, a vida, mas ao menos seu 'sentido"” (Foucault, "Réponse à une question", in DE I, p. 723).
}

${ }^{232}$ Cf. Foucault, "Foucault répond à Sartre”, in DE I, p. 692.

${ }^{233}$ Cf. Foucault, "Réponse à une question", in DE I, p. 709. 
exemplo, crê que ao falar em sistema, episteme ou a priori histórico, Foucault não reconhece que são os próprios homens que engendram essas estruturas ${ }^{234}$, Lacan, por seu turno, esclarece que o anti-humanismo de Foucault e dos estruturalistas em geral não significa negação do homem, mas simplesmente reconhecimento de que ele é determinado, e não soberano e absolutamente livre para decidir o rumo da história ${ }^{235}$.

Com efeito, no livro de 69 Foucault insiste que a arqueologia, mesmo não consistindo numa pesquisa sobre a origem, não ignora as transformações e as mudanças que ocorrem ao longo da história e que tais transformações tenham se dado por meio da práxis humana. É justamente analisando e comparando as práticas dos homens, num e noutro momento, que Foucault apreende a transformação. Porém, se é verdade que é o homem quem faz a história, é preciso ter claro que esse fazer não provém da decisão soberana de um sujeito absolutamente livre, mas que esse fazer está inserido numa malha de relações. São justamente essas relações que Foucault procura apreender a fim de compreender o que ele chama de "sistema das transformações". O filósofo explica:

Para analisar tais acontecimentos [o aparecimento de uma nova episteme], é insuficiente constatar
modificações e logo relacioná-las seja ao modelo teológico e estético da criação (com sua
transcendência, todo o jogo de suas originalidades e de suas invenções), seja ao modelo psicológico
da tomada de consciência (com seus precedentes obscuros, suas antecipações, suas circunstâncias
favoráveis, seus poderes de reestruturação), ou, ainda, ao modelo biológico da evolução. [...] O
desaparecimento de uma positividade e a emergência de uma outra implica diversos tipos de
transformações. [...] Em vez de invocar a força viva da mudança (como se esta fosse seu próprio
princípio), ou lhe procurar as causas (como se nunca passasse de puro e simples efeito), a arqueologia
tenta estabelecer o sistema das transformações em que consiste a "mudança"236.

No que diz respeito à mudança de episteme, à passagem de uma formação discursiva a outra, cabe à arqueologia, portanto, descrever o sistema de transformações. Como? Estabelecendo relações de analogias, de diferenças, de hierarquia, de complementaridades, de coincidência e de defasagem entre as práticas discursivas dum momento e doutro. Em suma, conclui Foucault, cabe à arqueologia “descrever a dispersão das próprias descontinuidades"237. Este é, pois, seu limite metodológico. Que não perguntemos, portanto, ao arqueólogo por que surge uma nova episteme, a partir de quem e quando exatamente. Sua única tarefa é a de diagnosticar as transformações ocorridas, e estabelecer o sistema das transformações.

\footnotetext{
234 Diz Garaudy: "Foucault não pode dar conta da passagem de uma estrutura à outra porque a estrutura, para ele é totalmente estrangeira ao homem. Ele fala de estrutura sem nunca falar dos homens que as engendra" (Garaudy, "Structuralisme et mort de l'homme", p. 296).

${ }^{235}$ Em 1969, na ocasião em que nosso autor apresenta a conferência “Qu'est-ce qu'un auteur?” na Sociedade francesa de filosofia, o psicanalista intervem no momento do debate e comenta: "gostaria de remarcar que, estruturalismo ou não, parece-me que não está em questão, nesse campo vagamente determinado por essa etiqueta, a negação do sujeito. Trata-se da dependência do sujeito, o que é extremamente diferente" (Foucault, "Qu'est-ce qu'un auteur?", in DE I, p. 848).

${ }^{236}$ Foucault, A arqueologia do saber, pp.193-4. Cf. ainda Foucault, “La naissance du monde”, in DE I, p.816.

${ }^{237}$ Foucault, A arqueologia do saber, p. 196.
} 
Em 1969, numa entrevista sobre $A$ arqueologia do saber Foucault afirma:

não procuro estudar o começo no sentido de origem primeira, do fundamento a partir do qual todo o resto seria possível. Não estou à procura desse primeiro momento solene a partir do qual, por exemplo, toda matemática ocidental foi possível. Não remonto a Euclides ou a Pitágoras. São sempre começos relativos que eu procuro, mais instaurações e transformações que fundamentos, fundações [...]. O que procuro não são relações que seriam secretas, escondidas, mais silenciosas e profundas que a consciência dos homens. Eu tento, ao contrário, definir relações que estão na superfície mesmo dos discursos, tento tornar visível o que não é visível porque está muito na superfície das coisas ${ }^{238}$.

É preciso, então, negar a tese de que a arqueologia não se preocupa com a história, com a mudança e com as transformações. O que ela não faz é procurar uma única origem, causa ou fundamento, seja na própria história, seja no sujeito. Procura, antes, diagnosticar "o sistema das transformações"239.

O diagnóstico, contudo, parece ser também o papel da genealogia, pelo menos tal como Foucault a define num artigo de 1971, intitulado "Nietzsche, la généalogie, l'histoire". É com a metáfora do médico que Foucault define o papel do genealogista que realiza o que ele chama de "história efetiva":

a história "efetiva" olha para o mais próximo, mas para dele se separar bruscamente e se apoderar à distância (olhar semelhante ao do médico que mergulha para diagnosticar e dizer a diferença). $\mathrm{O}$ sentido histórico está muito mais próximo da medicina do que da filosofia. "Historicamente" e "fisiologicamente" costuma dizer Nietzsche ${ }^{240}$.

De acordo com essa citação, parece que também a genealogia tem mais o papel de diagnosticar do que de fundar. Sua tarefa é "reconhecer os acontecimentos da história", diz Foucault ${ }^{241}$. Tarefa parecida com a da arqueologia que deve "descrever a dispersão das próprias descontinuidades". Com efeito, os dois métodos são muito próximos ${ }^{242}$. Em A ordem do discurso,

238 Foucault, "Michel Foucault explique son dernier livre”, in DE I, p. 800.

${ }^{239}$ Segundo Foucault, considerar a mudança não do ponto de vista de uma única causa, mas de um sistema de relações, é uma ideia que está presente em Saussure e que é determinante para todo o estruturalisamo, não só o linguístico (Cf. Foucault, "Linguistique et science social", in $D E I$, p. 852).

${ }^{240}$ Foucault, "Nietzsche, a genealogoa e a história", in Microfísica do poder, p. 29, grifo nosso. Vale notar que tanto em Nietzsche quanto em Foucault, o método genealógico é definido pelo termo médico "diagnóstico", o que nos faz pensar, ao menos em Nietzsche, numa aproximação entre os conceitos de vida/morte e saúde/doença. Aliás, seria interessante investigar a intrigante sugestão que Daniel Defert nos dá em seu texto que situa o primeiro curso de Foucault no Collège de France. Defert sugere que todo o ensinamento de Foucault nessa instituição se desenvolve em torno do enigma nietzschiano lançado em Gaia Ciência, IV, § 340: a de que Sócrates é um pessimista que considera a vida uma doença e que antes de morrer, por estar prestes a se curar da doença da vida, solicita o sacrifício de um galo para o deus da Medicina, Asclépio (Cf. Defert, "Situation du cours", p. 258).

241 Cf. Foucault, "Nietzsche, a genealogia e a história", p. 20, grifo nosso: "O genealogista necessita da história para conjurar a quimera da origem, um pouco como o bom filósofo necessita do médico para conjurar a sombra da alma. É preciso saber reconhecer os acontecimentos da história, seus abalos, suas surpresas, as vacilantes vitórias, as derrotas mal digeridas, que dão conta dos atavismos e das hereditariedades; da mesma forma que é preciso saber diagnosticar as doenças do corpo, os estados de fraqueza e de energia, suas rachaduras e suas resistências para avaliar o que é um discurso filosófico".

242 Em uma entrevista de 1967, indagado se considerava-se filósofo, Foucault afirma que é filósofo desde que entendamos que fazer filosofia é fazer diagnóstico: "filosofia tem por objetivo diagnosticar e não procura dizer a verdade que possa valer para todos e para todos os tempos. Eu procuro diagnosticar, realizar um diagnóstico do presente: dizer o que nós somos hoje, e o que significa, hoje, dizer o que dizemos [...]. Neste sentido posso me declarar filósofo" ("Qui êtes-vous, professeur Foucault?", in DE I, p. 634). 
Foucault confirma isso: "Entre o empreendimento crítico [arqueológico] e o empreendimento genealógico, a diferença não é tanto de objeto ou de domínio, mas sim, de ponto de ataque, de perspectiva e de delimitação"243.

E se a diferença não está no objeto, então, não nos é lícito pensar que se, por um lado, a arqueologia não tem como objeto a origem do discurso, por outro lado, a genealogia poderia tomála como questão. Não. Apesar do termo sugerir uma pesquisa sobre a origem, não é disso que se trata o método nietzschiano e também foucaultiano. Isso, é claro, se levarmos em conta as considerações que Foucault, em seu texto sobre Nietzsche, tece sobre a noção de origem.

De acordo com Foucault, os termos em alemão Entstehung (emergência) e Herkunft (proveniência) são preferíveis ao termo Ursprung (origem) para marcar o objeto da genealogia ${ }^{244}$. Isto porque este último termo pode assumir um caráter muito metafísico ao designar um fundamento originário: o fundamento originário da moral, da religião, do Mal. Todos os objetos que teriam interessado não à filosofia de Nietzsche, mas à de Platão ou mesmo à de Shopenhauer. E retomamando as palavras de Nietzsche, Foucault explica por que o filósofo alemão teria recusado a pesquisa da Ursprung:

Porque, primeiramente, a pesquisa, nesse sentido, se esforça para recolher nela [origem] a essência exata da coisa, sua mais pura possibilidade, sua identidade cuidadosamente recolhida em si mesma, sua forma imóvel e anterior a tudo o que é externo, acidental, sucessivo. Procurar uma tal origem é tentar reencontrar "o que era imediatamente", o "aquilo mesmo" de uma imagem exatamente adequada a si [...]. A alta origem é o "exagero metafísico que reaparece na concepção de que no começo de todas as coisas se encontra o que há de mais precioso e de mais essencial"; gosta-se de acreditar que as coisas em seu início se encontravam em estado de perfeição; que elas saíram brilhantes das mãos do criador, ou na luz sem sombra da primeira manhã. A origem está sempre antes da queda, antes do corpo, antes do mundo e do tempo; ela está do lado dos deuses, e para narrá-la se canta sempre uma teogonia 245

Recusa parecida com a de Foucault, em $A$ arqueologia do saber, em relação ao que ele chamou de "história tradicional". Como vimos, o filósofo negava ali uma pesquisa histórica de cunho antropológico, com pretensões totalizantes e que apagam a dispersão dos acontecimentos, em benefício das sínteses teleológicas e dos começos atemporais ${ }^{246}$. Se naquele momento, porém, somente a arqueologia servia de contraponto à "história tradicional", no texto de 71 sobre Nietzsche a genealogia entra em cena, aumentando o confronto. Pois é assim que vemos a relação entre os dois métodos foucaultianos: arqueologia e genealogia se somam, mais do que se contrapõem ou se substituem. Nesse sentido, ambas podem ser ditas pesquisas históricas; pesquisas históricas que, nos

\footnotetext{
${ }^{243}$ Foucault, A ordem do discurso, p. 67.

${ }^{244}$ CF. Foucault, "Nietzsche, a genealogia e a história", p. 16.

245 Foucault, "Nietzsche, a genealogoa e a história", pp. 17-8.

246 Sobre as proximidades entre a recusa da "história tradicional" tal como vemos em A arqueologia do saber e a recusa nietzschiana da história, cf. Foucault, "Nietzsche, a genealogia e a história”, pp. 26- 30.
} 
dois casos, recusam uma investigação dos fundamentos originários ou das teleologias e que se centram nas irrupções descontínuas dos acontecimentos. Pelo menos é isso que se pode depreender a partir da seguinte afirmação de Foucault sobre a genealogia, que parece muito próxima do que vimos sobre a arqueologia:

A história, genealogicamente dirigida, não tem por fim reencontrar as raízes de nossa identidade, mas ao contrário, se obstinar em dissipá-la; ela não pretende demarcar o território único de onde viemos, essa primeira pátria à qual os metafísicos prometem que nós retornaremos; ela pretende fazer aparecer todas as descontinuidades que nos atravessam ${ }^{247}$.

Assim, se Foucault afirma que os termos apropriado para designar o objeto da genealogia são Entstehung (emergência) e Herkunft (proveniência), a mesma coisa pode ser dita da arqueologia, uma vez que o objeto de ambas as pesquisas é o mesmo. Vimos, pois, que a arqueologia não é totalmente alheia ao tema da origem. E se isso ocorre é porque ela, de certo modo, pensa também sobre a emergência e a proveniência dos acontecimentos; pensa sobre suas irrupções; não que ela lhes dê um fundamento originário, uma única causa, mas os situa e os localiza: os diagnostica. Entretanto, se os dois métodos não são idênticos apesar de pensarem sobre o mesmo objeto, é preciso estar atento para as diferenças entre um e outro. A nosso ver, essas diferenças que, como afirma o próprio Foucault, têm mais a ver com a perspectiva e com o ponto de ataque do que com o objeto, podem ser notadas no texto de Foucault sobre Nietzsche. A partir das definições da pesquisa genealógica enquanto pesquisa da emergência e da proveniência, podemos certamente perceber uma proximidade entre os dois métodos; porém, chama a atenção a entrada em cena de dois elementos que, se não estavam ausentes das pesquisas arqueológicas, não tinham ali muito destaque: o corpo e a força. Vejamos, então, como as definições sobre a pesquisa genealógica parecem próximas da pesquisa arqueológica, mas como as noções de corpo e de força são agora centrais. Sobre a pesquisa da Herkunft (proveniência), diz Foucault:

[...] a proveniência diz respeito ao corpo. Ela se inscreve no sistema nervoso, no humor, no aparelho digestivo [...] O corpo - e tudo o que diz respeito ao corpo, a alimentação, o clima, o solo - é o lugar da Herkunft: sobre o corpo se encontra o estigma dos acontecimentos passados do mesmo modo que dele nascem os desejos, os desfalecimentos e os erros; nele também eles se atam e de repente se exprimem, mas nele também se desatam, entram em luta, se apagam uns aos outros e continuam seu insuperável conflito. O corpo: superfície de inscrição dos acontecimentos. [...] A genealogia, como análise da proveniência, está portanto no ponto de articulação do corpo com a história. Ela deve mostrar o corpo inteiramente marcado de história e a história arruinando o corpo ${ }^{248}$.

Sobre a Entstehung (emergência):

Entstehung designa de preferência a emergência, o ponto de surgimento. É o princípio e a lei singular de um aparecimento. [...] A genealogia restabelece os diversos sistemas de submissão: não a potência antecipadora de um sentido, mas o jogo causal das dominações. A emergência se produz sempre em um determinado estado das forças. [...] A emergência é portanto a entrada em cena das forças; é sua

${ }^{247}$ Foucault, "Nietzsche, a genealogia e a história”, pp. 34-5.

${ }^{248}$ Idem, pp. 20-2, grifo nosso. 
interrupção, o salto pelo qual elas passam dos bastidores para o teatro, cada uma com seu vigor e sua própria juventude ${ }^{249}$.

Demarcar o limite entre a arqueologia e a genealogia não é tarefa fácil, pois Foucault nos dá definições muito similares de uma e de outra. O filósofo afirma que ambas tratam do mesmo objeto, os acontecimentos históricos, mas com perspectivas diferentes. Acabamos de sugerir que a diferença de perspectiva talvez estivesse na ênfase que a genealogia confere às noções de corpo e de força. Porém, é preciso mesmo dizer que a diferença é de ênfase, pois já em A arqueologia do saber o tema da força é insinuado a partir da ideia de poder e de luta e o tema do corpo está presente na figura do desejo. O discurso, afirma Foucault no livro de 69:

aparece como um bem - finito, limitado, desejável, útil - que tem suas regras de aparecimento e também suas condições de apropriação e de sua utilização; um bem que coloca, por conseguinte, desde sua existência (...) a questão do poder; um bem que é, por natureza, o objeto de luta, e de uma luta política ${ }^{250}$.

A mesma ideia será defendida dois anos mais tarde, em A ordem do discurso. O discurso, diz Foucault, é objeto de desejo e poder do qual todos querem se apoderar ${ }^{251}$, sendo assim, é natural que diante da tarefa de pronunciar um discurso (lembremos aqui que esse texto se refere ao pronunciamento da aula inaugural do Collège de France) sinta-se certa inquietação. Foucault justifica, então, esse sentimento: "inquietação de sentir sob essa atividade, todavia cotidiana e cinzenta, poderes e perigos que mal se imagina; inquietação de supor lutas, vitórias, ferimentos, dominações, servidões, através de tantas palavras cujo uso há tanto tempo reduz as asperidades"252.

Mas, será, então, que a diferença entre o método arqueológico e genealógico é estritamente quantitativa, já que a diferença está na ênfase que cada uma delas dá ao objeto de estudo? Seguramente não. A nosso ver, existe também uma diferença de natureza, ou seja, qualitativa, entre um e outro método.

Em $A$ ordem do discurso, o filósofo defende que o papel da arqueologia é destacar os "princípios de ordenamento" do discurso, enquanto o da genealogia é destacar as "séries da formação efetiva do discurso" ${ }^{253}$. Em O uso dos prazeres, de 1983, Foucault parece voltar à mesma distinção: "a dimensão arqueológica da análise", diz, "permite analisar as próprias formas da

\footnotetext{
${ }^{249}$ Foucault, "Nietzsche, a genealogia e a história", pp. 23-4, grifo nosso.

${ }^{250}$ Foucault, A arqueologia do saber, p. 137, grifo nosso.

${ }^{251}$ Foucault, A ordem do discurso, p. 10, grifo nosso.

${ }^{252}$ Idem, p. 8, grifo nosso.

253 Idem, p. 69.
} 
problematização; a dimensão genealógica, sua formação a partir das práticas e de suas modificações" 254 .

Chama a atenção que tanto na aula inaugural de 71 quanto no livro de 83, a distinção entre a arqueologia e a genealogia está no caráter mais formal da primeira e no aspecto mais prático ou concreto da segunda. À arqueologia cabe a investigação dos princípios e das formas; à genealogia, a formação efetiva e as práticas. Foucault brinca dizendo que a arqueologia diz respeito à “desenvoltura estudiosa", enquanto "o humor genealógico será o de um positivista feliz"255. Brincadeiras à parte, essa distinção parece justificar a ênfase ou o privilégio que a genealogia atribui às questões do corpo e da força, pois é por meio deles que efetivamente um discurso se produz, que uma prática é exercida, que um uso se realiza.

À arqueologia, portanto, cabe o aspecto mais formal da pesquisa: aquele que se pergunta pelas regras ou princípios de ordenamento das práticas. A genealogia, por seu turno, pergunta-se também pelas práticas, porém, não tanto para encontrar sua ordem, mas para indicar as forças reais e concretas que estão inscritas nos corpos e nos desejos daqueles que as praticam e as sofrem. $\mathrm{O}$ primeiro método nos ajuda a compreender como se fala, o segundo aponta para o sistema de força e de interesse que está por trás deles, ou seja, aponta para quem fala.

Mas que não nos enganemos com a pergunta genealógica pelo quem fala. Em nada ela tem a ver com a procura de um sujeito soberano, seja ele psicológico ou transcendental. Ela aponta antes para um sistema real de lutas, usando os termos de Foucault. Ela não quer encontrar um sujeito como polo unívoco do sentido e da ação, mas antes um sistema de relações, relações de interesses, relações de forças, de lutas, combates. Relações estas que Foucault chamará de poder ${ }^{256}$.

Assim, se, por um lado, a arqueologia que investiga como se dão os usos que fazemos da linguagem mostra que eles estão determinados e inseridos no interior de um sistema de práticas que está além do sujeito e que não depende dele; por outro lado, a genealogia mostra as lutas que animam essas práticas, os interesses que as justificam, as forças e os desejos que as põem em movimento. Mas não é só isso. Ainda falta o mais importante: ao mostrar que por trás da história há luta de interesses, de vontades e de desejos, a genealogia mostra como realmente a história é construída; mostra que a história não é simplesmente correlata a práticas de sujeitos conscientes e livres e que nem sempre ela obedece à lei da razão. Mostra, ao contrário, que a história é correlata a

\footnotetext{
${ }^{254}$ Foucault, O uso dos prazeres, p. 15.

${ }^{255}$ Foucault, A ordem do discurso, p. 70.

${ }^{256}$ Numa conferência de 1978, Foucault explica que o termo poder é um operador metodológico que nomeia uma série de relações e que não se refere a nenhuma entidade, potência ou elemento transcendental. Nesse sentido, ele é apenas uma "grelha de análise" (Foucault, "Qu'est-ce que la critique?", p. 49).
} 
todo um sistema de relações que, na maioria das vezes, não são nem conscientes, nem racionais. Além disso, mostra também que por trás da história, mais do que uma liberdade absoluta, existe a dominação; mais do que depender das ações livres dos sujeitos, a história é tributária de uma série de disputas violentas, de combates de força e de lutas de interesses. E que, no interior desse sistema de lutas, o espaço concreto de liberdade possível será sempre restrito.

Concluindo. Se, por um lado, a arqueologia foucaultiana reacende o mote antropológico do uso por meio de uma análise do discurso e dos usos da linguagem, é somente com a genealogia de inspiração nietzschiana que Foucault poderá pensar, por meio de uma teoria do poder, esse uso em termos de liberdade. Visto que o fundamento ético da Antropologia de um ponto de vista pragmática está baseado numa teoria transcendental do sujeito, teoria que Foucault pretende contornar, nosso autor parece se utilizar de Nietzsche justamente ali onde não pode mais seguir com Kant. É, portanto, por meio de uma teoria do poder baseada em relações de interesses que mostram as disputas reais dentro das quais estamos inseridos que Foucault, a um só passo, contorna a questão do sujeito transcendental e indica a instância daquilo que podemos fazer de nós mesmos como agentes livres. 


\section{SEGUNDA PARTE \\ NIETZSCHE E A GENEALOGIA}




\title{
CAPÍTUlO 4. DOIS PARADIGMAS DA VONTADE DE SABER: ARISTÓteleS E NIETZSCHE
}

\author{
Foucault, Nietzsche e Heidegger
}

Daniel Defert, um dos organizadores e editores da obra de Foucault, lembra o cenário francês no início da década de 70 no que diz respeito a Nietzsche. No mesmo ano em que Foucault dá seu primeiro curso no Collège de France, 1971, Pierre Klossowski publica a tradução de Nietzsche, de Heidegger ${ }^{257}$. Essa sincronia de datas, mais do que coincidência, marca uma importante peculiaridade: falar em Nietzsche na França neste período sem dúvida nenhuma é falar em Heidegger. Que Heidegger tenha tido importância para Foucault é fato que o próprio filósofo reconhece em uma entrevista de 1984, "Le retour de la morale". Diz Foucault: "Todo meu devir filosófico foi determinado pela minha leitura de Heidegger" ${ }^{258}$. Não nos cabe aqui retomar a possível influência que o filósofo da floresta negra exercera sobre Foucault, influência que talvez tenha se iniciado ainda na década de 40, como nota Didier Eribon, com a leitura de La Philosophie de Martin Heidegger (1942), de Alphonse De Waelhens, e com os cursos dados pelo heideggeriano Jean Beaufret, na École Normale Supérieure (ENS) ${ }^{259}$. De qualquer modo, o importante a notar é que o Nietzsche de Foucault passa pelo Nietzsche de Heidegger. Confirma Foucault na mesma entrevista citada acima: "É provável que se eu não tivesse lido Heidegger, eu não teria lido Nietzsche. Tentei ler Nietzsche nos anos cinquenta, mas Nietzsche sozinho não me dizia nada! Enquanto que Nietzsche e Heidegger, isso foi o choque filosófico!"260

Vale, contudo, nos perguntar como nosso autor leu o Nietzsche de Heidegger. Sobre isso, Daniel Defert lembra que Foucault frequentou um curso dado por Jean Wahl, em 1946-7, na ENS, sobre Heidegger, passando por sua intepretação de Nietzsche; e Jean Wahl, observa Defert, é um

\footnotetext{
${ }^{257}$ O livro de Heidegger sobre Nietzsche consiste nas compilações das aulas dadas por ele na Universidade de Friburgo entre 1936 e 1940 e de considerações realizadas entre 1940 a 1946. O livro foi publicado em dois tomos e os estudiosos de Heidegger costumam ver entre o primeiro e o segundo tomo a marca de uma ruptura no pensamento heideggeriano. Interessar-nos-á aqui somente algumas teses de Heidegger apresentadas no primeiro tomo, mais especificamente na terceira parte, intitulada "A Vontade de potência enquanto conhecimento".

${ }^{258}$ Foucault, "Le retour de la morale”, in DE II, p. 1522.

${ }^{259}$ Cf. Eribon, Michel Foucault, p. 49.

${ }^{260}$ Foucault, "Le retour de la morale", in $D E I I$, p. 1522.
} 
"brilhante opositor" de Heidegger ${ }^{261}$. Ademais, vale também ter em mente que Foucault, além de Heidegger, teve outras referências no que diz respeito à leitura de Nietzsche. Refiro-me aqui à interpretação nietzschiana que corria na França a partir de 1945 com Bataille, Blanchot, Klossowski, Deleuze e o já citado Jean Wahl ${ }^{262}$. Provavelmente o Nietzsche de Foucault está mais próximo ao dessa tradição francesa do que ao de Heidegger ${ }^{263}$.

Se Daniel Defert tem razão, Heidegger consiste no alvo de Foucault em seu primeiro curso no Collège de France. Heidegger, afirma Defert, é “o não-nomeado desse curso, mas que poderia ser o seu alvo, já que a tradução de seu Nietzsche por Pierre Klossowski estava prevista para este mesmo ano de $1971^{\prime 264}$. De acordo com Defert, seria possível assinalar importantes divergências entre o Nietzsche de Foucault e o de Heidegger. Retomemos algumas delas.

Em primeiro lugar, parece haver uma divergência importante no que diz respeito à relação entre o método genealógico e o conhecimento. Segundo Defert, Foucault vê em Nietzsche o autor que, por meio da genealogia, põe em questão os fundamentos da teoria do conhecimento e da verdade vigentes desde Platão. Que fundamentos são esses? O sujeito puro de conhecimento, por um lado, e os objetos reais a serem conhecidos, por outro. São, portanto, os efeitos da genealogia nietzschiana no que tange às teorias do sujeito e do objeto que interessam a Foucault, conclui Defert $^{265}$. Os trechos de Nietzsche citados por Foucault parecem confirmar isso; em geral nosso autor retoma a discussão de Nietzsche sobre o conhecimento que mostra que todo conhecimento

\footnotetext{
${ }^{261}$ Cf. Defert, "Situation du cours", p. 267, n. 38. Seria interessante verificar mais de perto a importância de Jean Wahl para Foucault no que diz respeito a Heidegger. Não temos acesso ao curso a qual Daniel Defert se refere, dado em 46-47 na ENS, e que teria passado pela interpretação de Heidegger sobre Nietzsche. Porém, está publicado o curso que Jean Wahl realizou na Sorbonne também sobre Heidegger um ano antes. O curso intitula-se "Introduction à la pensée de Heidegger" e foi dado de janeiro a junho de 1946. Didier Eribon nada fala sobre esse curso, mas é difícil que Foucault o tenha frequentado, já que chega a Paris no outono de 1945 a fim de se dedicar integralmente aos estudos para o concurso da ENS, na qual será aceito em julho de 1946. De qualquer modo, valeria a pena ler esse curso a fim de verificar o posicionamento de Jean Wahl frente a Heidegger. Ao que tudo indica, Jean Wahl não está de acordo com o modo que Heidegger lê Kant. Uma visão crítica que parece próxima da de Jules Vuillemin. Como Vuillemin, Jean Wahl crê que Heidegger operou uma distorção no pensamento de Kant ao dizer que Kant faz ontologia. Diz Wahl: "se entramos na concepção que Heidegger faz de Kant, temos algumas reservas mais sérias a fazer. De acordo com ele, Kant não é um teórico do conhecimento, mas edifica uma teoria da realidade. O que é difícil de dizer [...]. Além de considerar Kant como um ontologista e um metafisico, ele pensa que o transcendental, para Kant, significa ontologia, que Kant desenvolve um quadro de conhecimentos ontológicos. Aí ainda ele vai muito longe na interpretação de Kant” (Wahl, Introduction à la pensée de Heidegger. p. 156).
}

262 Cf. Defert, "Situation du cours", p. 267. Onde exatamente Foucault encontra as interpretações nietzschianas desses autores? No que diz respeito a Bataille, podemos lembrar seu Sur Nietzsche, de 1945; em Blanchot, temos L'Entretien infinie, de 1969; é de 1962 o livro de Deleuze Nietzsche et la philosophie e de 1968 Differénce et Répétition que, segundo Defert, é uma interpretação de Nietzsche que pensa o ser enquanto diferença (Cf. Defert, op. cit, p. 267); por fim, no que diz respeito a Klossowski, além da tradução do livro de Heidegger em 1971, ele publica em 1969 Nietzsche e o Círculo Vicioso.

263 Sobre a recepção de Nietzsche na França cf. Marton, "Voltas e reviravoltas. Acerca da recepção de Nietzsche na França".

${ }^{264}$ Defert, op. cit., p. 260.

265 Idem, p. 259. 
nascem, não de seu próprio interior, de uma faculdade pura e livre, mas de algo exterior e diferente da razão: impulsos, paixões, lutas, força e necessidade de viver. E se para Foucault a genealogia nietzschiana interessa enquanto método que desarma a teoria do conhecimento baseada na soberania do sujeito e do objeto, para Heidegger, ao contrário, a genealogia não passa de mais uma forma de conhecimento nos moldes da metafísica tradicional, que ainda estaria presa à velha ideia de sujeito, objeto e verdade ${ }^{266}$. Segundo Defert, o que permite Heidegger afirmar que a filosofia de Nietzsche é a última expressão da metafísica ocidental é a sua insistência na centralidade do conceito de vontade de poder e da aproximação dessa noção à noção de vontade de verdade ${ }^{267}$. Essa aproximação poderia ser encontrada, por exemplo, na seguinte passagem do livro de Heidegger sobre Nietzsche:

Se o pensamento da Vontade de poder é o pensamento fundamental da metafísica nietzschiana e a última metafísica ocidental é, então, a partir da Vontade de poder que convém determinar a essência do conhecimento e a essência da verdade. A verdade contém e dá de tal modo o que é, o ente, no interior do qual o homem é ele mesmo um ente, que o homem se relaciona sempre com o ente. É por isso que o homem, em todos os seus comportamentos, se liga, de uma maneira ou de outra, ao verdadeiro. A verdade é aquilo a que o homem aspira, aquilo que ele exige que reine em tudo o que ele faz ou que ele deixa de fazer, em tudo o que ele deseja, em tudo o que ele dá com assentimento, em tudo o que ele experimenta e em tudo o que ele forma, em tudo o que ele sofre, assim como em tudo o que o permite vencer. Fala-se, então, de uma "vontade de verdade"268.

Foucault seguramente não estaria de acordo com a tese de que, segundo Nietzsche, a verdade é aquilo a que todo homem aspira e deseja conhecer, como se toda relação com a verdade significasse uma vontade de conhecimento. Nietzsche, ao contrário, é para Foucault o filósofo que justamente põe em questão essa "vontade de verdade" ao se perguntar pelo seu valor. Ou seja, é o filósofo que ao desimplicar verdade e conhecimento tenta compreender a vontade de verdade, não como vontade de conhecer, mas como uma vontade de saber guiada pelo poder. Note-se, portanto, que Foucault propõe uma diferença entre conhecimento e saber. O primeiro deve ser entendido nos moldes da metafísica clássica: sistema que supõe conaturalidade entre sujeito de desejo e sujeito de conhecimento e que supõe uma relação a priori entre sujeito e objeto. O saber, por outro lado, é, com as palavras de Foucault, "o conhecimento liberado da relação sujeito-objeto"269. Ou seja, é um sistema que não tem o sujeito puro e o objetivismo como seus fundamentos. Muito pelo contrário. O que está por trás do saber não é uma vontade pura que naturalmente leva ao conhecimento, mas

\footnotetext{
${ }^{266}$ Cf. Heidegger, Nietzsche, t. I, livro III “La volonté de puissance en tant que connaissance”.

${ }^{267}$ Cf. Defert, op. cit., p. 263.

${ }^{268}$ Heidegger, Nietzsche, p. 388.

${ }^{269}$ Foucault, Leçons sur la volonté de savoir, p. 205.
} 
uma série de impulsos inconscientes que tomam o conhecimento "como objeto de um querer, o fim de um desejo, o instrumento de uma dominação, o motivo de uma luta"270.

Nietzsche é, então, para Foucault o filósofo que se pergunta: “Certo, queremos a verdade: mas por que não, de preferência, a inverdade? Ou a incerteza? Ou mesmo a insciência?"271. Para Foucault, Nietzsche certamente não é mais um filósofo que, do interior da tradição da metafísica ocidental, pensa a verdade enquanto valor de verdade, mas que questiona a verdade enquanto valor. A vontade de verdade, em Nietzsche, portanto, não pode ser interpretada como vontade de conhecimento, mas antes como vontade de poder. Confirma Foucault, contra Heidegger:

Em Nietzsche, o conhecimento é um efeito ilusório da afirmação fraudulenta da verdade: a vontade que os leva um e outro a esse duplo caráter: (1) de ser não vontade de conhecimento, mas vontade de poder; (2) de fundar entre conhecimento e verdade uma relação de crueldade recíproca e de destruição ${ }^{272}$.

É, pois, justamente a oposição entre considerar o valor de verdade da verdade e a verdade enquanto valor, que Foucault procura desenvolver ao longo de seu primeiro curso no Collège de France, Leçons sur la volonté de savoir, de 1971.

A partir dessa primeira e grande oposição entre Heidegger e Foucault no que diz respeito à maneira como cada um vê a relação entre verdade e conhecimento em Nietzsche, desdobram-se outras oposições. Para poder tratar cada uma delas com atenção seria preciso retomar cuidadosamente o texto de Heidegger sobre Nietzsche. Não nos interessa, contudo, fazê-lo aqui. Por ora, continuemos com as indicações de Daniel Defert sobre as possíveis contraposições que Foucault faz a Heidegger ao organizar seu primeiro curso de 1971.

Foucault, nota Defert, não quer "se aventurar nos caminhos gregos do conhecimento seguindo os passos heideggerianos" ${ }^{273}$. Primeiro porque as análises de Foucault sobre a Grécia não se baseiam em análises filológicas, mas em análises históricas; segundo porque o período que interessa a Foucault é o período arcaico, o mesmo período que interessa a Nietzsche, por exemplo, em $O$ nascimento da tragédia. Nesse sentido, diz Defert: a Grécia de Foucault "é a Grécia nietzschiana" ${ }^{274}$.

Por fim, uma última oposição a Heidegger e que, no fim das contas, parece pautar a tese mais geral de Foucault sobre Nietzsche, diz respeito à concepção de história da filosofia. Se para o

\footnotetext{
${ }^{270}$ Foucault, Leçons sur la volonté de savoir, p. 18.

${ }^{271}$ Nietzsche, Além do bem e do mal, § 1, p. 9

${ }^{272}$ Foucault, Leçons sur la volonté de savoir, p. 209.

${ }^{273}$ Defert, op. cit., p. 266.

${ }^{274}$ Idem, p. 272.
} 
filósofo alemão, Nietzsche ainda pertence à tradição da metafísica ocidental de Platão e Aristóteles, Foucault propõe uma ruptura importante entre o pensamento nietzschiano e o da tradição metafísica que seria caracterizada por Aristóteles, por se tratarem de dois modos distintos de considerar a nossa relação com a verdade. Aristóteles e Nietzsche seriam, assim, dois paradigmas diferentes da vontade de saber. O primeiro toma a verdade em seu valor de verdade e a valoriza enquanto discurso apofântico. Nietzsche, por seu turno, assim como os mestres de verdade da Grécia arcaica e os sofistas, não se importa tanto com o valor de verdade das proposições, mas com a eficácia das palavras. De um lado, a tradição da filosofia ocidental que vê na verdade a manifestação da essência do ser; de outro lado, a tradição pré e pós-filosófica que crê que a enunciação da verdade é, antes de tudo, a manifestação de um poder. Para a primeira, importa o que se diz com a verdade, para a segunda, o importante é quem diz a verdade, já que não é qualquer um e de qualquer maneira que se pode dizer a verdade. Valeria, então, retomar a oposição proposta por Foucault entre Aristóteles e Nietzsche no curso de 71, a fim de compreendermos de que modo a genealogia nos ajuda a resolver o problema de quem fala.

Aristóteles e Nietzsche: dois paradigmas da vontade de saber

Ao justificar o título do curso "A vontade de saber", Foucault afirma que sua intenção era estabelecer uma teoria da vontade de saber que pudesse servir de fundamento às análises históricas desenvolvidas até então ${ }^{275}$. Essa teoria deveria mostrar, em linhas gerais, aquilo que Foucault já anunciara na aula inaugural de 2 de dezembro de 1970, a saber, que todo sistema de separação entre verdadeiro e falso não passa de um sistema de exclusão e um sistema de coerção que implica luta, dominação e violência ${ }^{276}$. É quase com os mesmos termos que Foucault, na primeira aula do curso, em 9 de dezembro de 1970, apresenta sua intenção: "tratar-se-ia de saber se a vontade de verdade não é tão profundamente histórica como qualquer outro sistema de exclusão [...]; trata-se, em suma, de saber quais lutas reais e quais relações de dominação estão engajadas na vontade de verdade" 277 .

\footnotetext{
275 Foucault, Leçons sur la volonté de savoir, p. 3.

${ }^{276}$ Cf. por exemplo, Foucault, Leçons sur la volonté de savoir, p. 4 e p. 6. Em A ordem do discurso lemos: “Certamente, se nos situamos no nível de uma proposição, no interior de um discurso a separação entre o verdadeiro e o falso não é nem arbitrária, nem modificável, nem institucional, nem violenta. Mas se nos situamos em outra escala, se levantamos a questão de saber qual foi, qual é constantemente, através de nossos discursos, essa vontade de verdade que atravessou tantos séculos de nossa história, ou qual é, em sua forma muito geral, o tipo de separação que rege nossa vontade de saber, então é talvez algo como um sistema de exclusão (sistema histórico, institucionalmente constrangedor) que vemos desenhar-se" (p. 14).
}

${ }^{277}$ Foucault, Leçons sur la volonté de savoir, p. 4. 
Essa tese de cunho nietzschiano deverá ser defendida retomando o próprio Nietzsche. A oposição entre Nietzsche e Aristóteles, proposta desde a primeira aula, deverá, então, servir para indicar uma alternativa à crença, "que se impõe a nós há bastante tempo"278, de que o discurso verdadeiro não está ligado nem ao exercício do poder, nem ao desejo. Ou seja, a oposição Nietzsche-Aristóteles deverá servir para mostrar que é em Nietzsche, mais do que em qualquer outro filósofo, que Foucault encontra uma teoria que justifica a díade saber-poder percorrida por ele em suas análises históricas. É, então, da seguinte maneira que Foucault justifica a retomada da genealogia nietzschiana no resumo do curso Leçons sur la volonté de savoir:

Os estudos empíricos, sobre a psicopatologia, sobre a medicina clínica, sobre a história natual etc. permitiram isolar o nível das práticas discursivas. As características gerais dessas práticas e os métodos próprios para analisá-las foi inventariado sob o nome de arqueologia. As pesquisas empreendidas acerca da vontade de saber deveriam agora poder dar a esse conjunto uma justificação teórica $^{279}$.

Ao retomarmos a oposição entre Nietzsche e Aristóteles, vale ter em mente que, para Foucault, Nietzsche é o filósofo do poder. Em uma entrevista de 1975, Foucault dá testemunho disso: "Se eu fosse pretensioso, daria como título geral ao que eu faço: genealogia da moral”. Em seguida ele explica a importância do filósofo para o seu trabalho: "Nietzsche é quem deu como alvo essencial, digamos ao discurso filosófico, a relação de poder [...]. Nietzsche é o filósofo do poder, mas que conseguiu pensar o poder sem se fechar no interior de uma teoria política". Por fim, conclui sobre sua apropriação do filósofo: "A única marca de reconhecimento que podemos testemunhar a um pensamento como o de Nietzsche é precisamente o de utilizá-lo, deformá-lo, fazê-lo falar, gritar. E que os comentadores digam se somos ou não fiéis, não tem o menor interesse" 280 .

Vejamos, então, como Foucault "utiliza" Nietzsche contra Aristóteles e como isso vai permitindo a ele construir uma teoria sobre a vontade de saber que fundamente suas análises históricas.

Do curso dado por Foucault no Collège de France entre o final de 1970 e o início de 1971, 12 aulas foram editadas e publicadas. Por ora, interessam-nos as quatro primeiras, pois são nelas que Foucault se debruça sobre Aristóteles e sua concepção de verdade e a última, onde Foucault fala sobre Nietzsche. Ainda no que diz respeito a Nietzsche, nos interessa de modo particular uma aula dada em Montreal em abril de 71 e que foi publicada junto com o primeiro curso Leçons sur la volonté de savoir.

\footnotetext{
${ }^{278}$ Foucault, Leçons sur la volonté de savoir, p.15.

${ }^{279}$ Idem, p. 218.

${ }^{280}$ Foucault, "Entretien sur la prison: le livre et sa méthode”, in DE I, p. 1621.
} 
“Todos os homens, por natureza, desejam saber... Que homem, então, não é filósofo e como a filosofia não seria absolutamente necessária a todos?". É com essas palavras que Foucault introduz Aristóteles a seus ouvintes, em sua primeira aula. Por mais que o nome "filosofia" aponte para a ideia de amor pelo saber e que muitos filósofos tenham nomeado o desejo de conhecer e o amor pela verdade, como Aristóteles, o discurso filosófico, segundo Foucault, em nada nos ajuda a pensar a vontade de saber. Isto porque, antes de tratar propriamente de vontade e de saber, como duas noções distintas e exteriores uma à outra, os filósofos apagaram essa diferença e exterioridade e trataram a vontade de saber ou de conhecimento do interior do próprio conhecimento. Aristóteles seria um exemplo paradigmático.

O texto que interessa é o início da Metafísica: "Todos os homens, por natureza, desejam conhecer. Sinal disso é o prazer que nos proporcionam os nossos sentidos; pois, ainda que não levemos em conta a sua utilidade, são estimados por si mesmos; e, acima de todos os outros, o sentido da visão"281.

De acordo com Foucault, essa passagem evidencia três teses: que existe um desejo que leva ao saber; que este desejo é universal e se encontra em todos os homens; que este desejo é dado pela natureza.

É em outras obras de Aristóteles que Foucault encontra os argumentos que justificam as teses da Metafísica. Em De anima (III, 2, 425b, 26 e ssg.), por exemplo, Aristóteles mostraria que a sensação é um conhecimento qualitativo, já que a sensação aí é considerada uma atividade da alma sensitiva que tem como resultado apreender a qualidade das coisas. Na Ética a Nicômaco (X, 5), por outro lado, Aristóteles defenderia que, quando a sensação se dá da maneira como se deve, ela é acompanhada de $\operatorname{prazer}^{282}$.

Foucault, então, toma um exemplo para explicitar as teses de Aristóteles. Trata-se do caso daquilo que se mostra agradável a um doente e a uma pessoa sã. Somente na pessoa de boa saúde o prazer da sensação pode ser dito verdadeiramente agradável, e pode ser considerado verdadeiramente um prazer. Isso porque é somente na pessoa sã que a atividade sensitiva da alma,

\footnotetext{
${ }^{281}$ Aristóteles, Metafisica, Livro I, 980a 1-25, p. 36.

282 Diz Aristóteles: “as mesmas coisas não parecem doces a um faebricitante e a um homem com saúde - nem quentes a um homem fraco e a um homem robusto. O mesmo se dá em outros casos. Mas em todas as coisas, o que parece a um homem bom é considerado como sendo realmente tal. Se isto é correto como se afigura ser, e a virtude e o homem bom como tais são a medida de todas as coisas, serão verdadeiros os prazeres os que lhe parecerem tais, e verdadeiramente agradáveis as coisas em que ele se deleitar" (Aristóteles, Ética a Nicômaco, X, 5, p. 186).
} 
as sensações, apreendem de maneira adequada as qualidades dos objetos. Somente na pessoa de boa saúde as sensações conhecem de modo adequado, ou seja, conhecem a verdade dos objetos. Donde Foucault conclui, seguindo Aristóteles: “onde não há conhecimento, não há verdadeiramente prazer" 283 .

No que diz respeito ao sentido da visão, é no De anima e na Ética a Eudemo que Foucault nos dá mais subsídios para compreender a tese de que a visão é a sensação que dá mais a conhecer e, por conseguinte, proporciona mais prazer. Ela dá mais a conhecer uma vez que, além dos dados sensíveis, ela também apreende a unidade a que estão ligados os dados sensíveis. Além de perceber uma cor, por exemplo, a visão também distingue e percebe o indivíduo que porta a cor. Ademais, ao passo que os prazeres dos outros sentidos, como o gosto e o tato, estão abertos à intemperança e sujeitos a se tornarem um desprazer, o prazer da vista não extrapola seus limites e é, portanto, sempre um prazer verdadeiro.

Entretanto, se a sensação e seu prazer são exemplos satisfatórios de que o desejo de conhecer é natural no homem, como explicar que os animais, que também têm sensações, não desejam naturalmente conhecer? De acordo com Foucault, a resposta de Aristóteles a essa pergunta encontra-se na diferença genérica que o filósofo estabelece entre homens e animais. A diferença básica está no fato de os homens sentirem prazer a partir de sensações inúteis. O que significa, como veremos, que, nos homens, o desejo natural de conhecer diz respeito às sensações que têm um fim em si mesmas e que são, por conseguinte, inúteis.

Uma importante diferença entre os animais e os homens está na audição, sentido que nem todo animal possui. É graças ao ouvido que percebemos sons inarticulados que serão a base de nossa linguagem; linguagem essa que deverá ainda contar com a memória que permite fixar o sentido desses sons inarticulados e que nos torna seres capazes de aprender, ou seja, de receber educação.

Determinante também na diferenciação entre homens e animais está a arte (tékhne) e a ciência (episteme). Ambas são ensinadas; contam com a capacidade do homem de aprender, ou seja, contam com a memória e com a escuta. E se, por um lado, a arte e a ciência permitem ao homem extrair da multiplicidade da experiência um juízo universal, por outro lado, elas são menos eficazes do que a própria experiência que, essa sim, reconhece o caso particular e a ocasião de agir ${ }^{284}$.

\footnotetext{
${ }^{283}$ Foucault, Leçons sur la volonté de savoir, p. 10.

${ }^{284}$ Cf. Aristóteles, Metafísica, I, 981a 15: "a experiência é conhecimento do particular e a arte, do universal: ora, todas as ações e produções visam sempre o caso particular; pois o médico não cura o homem [...] mas a Calias, a Sócrates [...]. Se, por conseguinte, alguém possui a teoria sem a experiência e reconhece o universal sem, no entanto, conhecer o indivíduo que nele se inclui, esse alguém muitas vezes falhará no tratamento, já que é o indivíduo que cumpre curar".
} 
Por fim, uma última diferença importante que caracteriza os homens frente aos animais é a sofia, ou seja, o conhecimento da causa, da essência, do universal. Esse tipo de conhecimento, que é o conhecimento supremo, para Aristóteles, só serve a si mesmo, tem a si mesmo como fim e, portanto, não tem utilidade nenhuma.

A diferença entre homens e animais, portanto, não está no fato de só os homens conhecerem, pois os animais têm o conhecimento da sensação. A diferença está numa forma específica de conhecimento: o conhecimento das causas e da essência, a sofia. Os animais não possuem aquilo que é necessário para esse tipo de conhecimento: nem audição e memória, nem arte e ciência. Apesar disso, os animais vivem. A diferença entre homens e animais, portanto, está no fato de os animais só terem conhecimento daquilo que é útil para a vida, enquanto os homens também podem conhecer o que é inútil. Com as palavras de Aristóteles, poderíamos dizer que os animais podem até saber ou conhecer como são as coisas, contudo, só os homens "conhecem o porquê e a causa"285 das coisas.

Assim, a satisfação que os homens têm com certas sensações inúteis é o caso particular de um tipo bem preciso de conhecimento, o conhecimento das essências e das causas, que não visa nenhuma utilidade para a vida, mas que tem como fim o próprio conhecimento.

Visto, porém, que o desejo de conhecer que está inscrito na natureza humana se apresenta como prazer que sentimos a partir de certas sensações sem utilidade, e que essas sensações inúteis só se encontram na natureza do homem, é preciso ainda se perguntar como se dá a passagem entre o desejo e o prazer.

No que diz respeito a esse problema, trata-se de entender, de acordo com Foucault, por que Aristóteles usa o termo agapêsis e não edoné ou eudaimonia para designar o prazer proveniente das sensações inúteis. Edoné, segundo Foucault, é o termo usado por Aristóteles para nomear o prazer sensorial e animal que acompanha todas as atividades que se desenrolam de modo conveniente; o que acompanha a atividade mais alta, a atividade da virtude e da contemplação, que são atividades propriamente humanas, é a felicidade (bonheur), dita eudaimonia. O prazer proveniente das sensações inúteis, no entanto, parece estar entre a edoné e a eudaimonia. Por um lado, o agapêsis é uma espécie de edoné na medida em que é um prazer proveniente de uma sensação, por outro lado, ao passo que essa sensação apreende algo que já é da ordem da contemplação (a qualidade própria das coisas, a essência qualitativa das coisas ou ainda a verdade mesma das coisas), o prazer que acompanha esse conhecimento sensorial aponta de certo modo para a eudaimonia. Resume

\footnotetext{
${ }^{285}$ Aristóteles, Metafisica, I, 981 a 31-2.
} 
Foucault: "Dualidade então dessa palavra agapêsis como se ela designasse a matéria do prazer sensorial e animal, tomando a forma genericamente humana da felicidade" ${ }^{286}$.

Mas, na medida em que o prazer que vem com as sensações inúteis tem a forma humana da felicidade, esse prazer não tem mais a ver nem com o desejo, nem com o corpo, mas com a verdade. Esclarece Foucault: "o movimento que vai da sensação em direção ao conhecimento sereno e incorporal das causas, esse movimento é já em si mesmo vontade obscura de ascender a essa sabedoria, esse movimento é já filosofia" ${ }^{287}$. Assim, aquele desejo de conhecer que, de acordo com Aristóteles, é natural, é da ordem da contemplação e da teoria. É certo que ele parte das sensações e do corpo, contudo, sua finalidade, desde o início, é a contemplação da verdade. O desejo de conhecer, em Aristóteles, portanto, não tem utilidade; o prazer sensível que ele produz não é de nenhuma utilidade para a vida animal e suas necessidades. Ele é simplesmente um desejo de conhecer inscrito já na natureza das sensações cuja finalidade é o conhecimento teórico, é o acesso à verdade. Deseja-se conhecer por conhecer e por nenhum outro motivo. O desejo de conhecer está, assim, fechado no interior do próprio conhecimento: "o desejo de conhecer não escapa em sua natureza, em seu ato, em seu poder, desse conhecimento que ele deseja" ${ }^{288}$. Desse modo, arremata Foucault: “o desejo não é, apesar da aparência, nem anterior, nem exterior ao conhecimento já que [...] um conhecimento feliz e de pura contemplação é já, em si mesmo, a causa desse desejo de conhecer" 289 . No fim das contas, portanto, "o desejo não é mais causa, mas é o conhecimento que torna-se causa dele mesmo" ${ }^{290}$. E aqui tocamos naquilo que realmente interessa para Foucault.

Vimos que a oposição entre Aristóteles e Nietzsche deveria servir para evidenciar dois paradigmas distintos sobre a vontade de saber. E se Nietzsche, como veremos, é o filósofo que procura resgatar a ideia de que todo conhecimento tem uma causa que lhe é exterior, Aristóteles, como acabamos de ver, ao menos aos olhos de Foucault, é o filósofo que, ao contrário de Nietzsche,

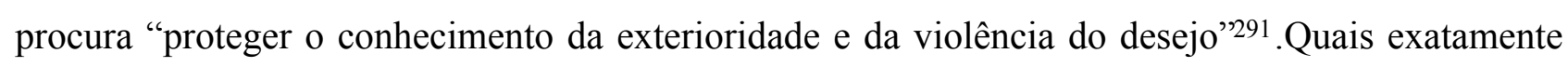
são as implicações de tal vontade de saber?

\footnotetext{
${ }^{286}$ Foucault, Leçons sur la volonté de savoir, p. 13.

${ }^{287}$ Idem, p. 14.

288 Idem, p. 17.

${ }^{289}$ Idem, p. 14.

290 Idem, p. 19.

291 Idem, p. 17.
} 
Em primeiro lugar, ela supõe a identidade entre o sujeito que deseja e o sujeito que conhece. "O sujeito de desejo e o sujeito de conhecimento fazem um"292, confirma Foucault. Não é possível desejar sem conhecer, nem conhecer sem desejar, afinal o objeto de um e de outro é o mesmo, a saber: a verdade. Ou seja, quem conhece a verdade, deseja a verdade e quem deseja a verdade, a conhece. Com as palavras de Foucault:

\begin{abstract}
Este envolvimento [do desejo no interior do próprio conhecimento] [...] tem por consequência que o saber e o desejo não estão em dois lugares diferentes, detidos por dois sujeitos ou dois poderes, mas que aquele que deseja o saber é já aquele que o possui ou que é capaz de possuí-lo. [...] um só sujeito vai do desejo de saber ao conhecimento, pelo simples fato de que se ele não estivesse lá como precedência do desejo, o desejo mesmo não existiria. E inversamente, o desejo de conhecer é já em sua natureza alguma coisa como o conhecimento, alguma coisa do conhecimento. Ele não pode querer o conhecimento por outra coisa que ele mesmo, já que é a partir do conhecimento que ele quer conhecer. Ele é ao mesmo tempo seu objeto, seu fim e sua matéria ${ }^{293}$.
\end{abstract}

Desse modo, a vontade de saber, em Aristóteles, por não levar em conta a exterioridade existente entre desejo e conhecimento, não considera que por trás do conhecimento da verdade pode haver um desejo violento, uma vontade de dominação ou uma força de exclusão e rejeição: "é sem violência, sem apropriação e sem luta, e também sem comércio, mas pela simples atualização de sua natureza que aquele que deseja o conhecimento acabará por alcançar o saber"294. Neste contexto, diz Foucault, a relação de exterioridade entre desejo e conhecimento proposta por Nietzsche será escandalosa 295 . Vejamos, então, como o filósofo alemão oferece, segundo Foucault, um outro paradigma para pensarmos a relação entre desejo e conhecimento ou, com outros termos, entre vontade e verdade.

A vontade de saber em Nietzsche: o conhecimento como invenção

Na segunda aula do curso de 1971, Leçons sur la volonté de savoir, tendo já usado Aristóteles como paradigma de certa vontade de saber, Foucault esclarece, então, como irá usar Nietzsche: "os textos de Nietzsche podem (e devem) ser lidos como uma tentativa de afastar o desejo de conhecer e a lei do conhecimento." 296

Em linhas gerais, pode-se dizer que, segundo Foucault, todo o esforço de Nietzsche é no sentido de passar para o lado daquilo que está fora do conhecimento. O esforço de Nietzsche teria

\footnotetext{
${ }^{292}$ Foucault, Leçons sur la volonté de savoir, p. 19.

${ }^{293}$ Idem, pp. 17-8.

294 Idem, p. 17.

${ }^{295}$ Cf. Foucault, Leçons sur la volonté de savoir, p. 18.

${ }^{296}$ Foucault, Leçons sur la volonté de savoir, p. 25.
} 
sido, pois, o de mostrar que na raiz do conhecimento há um desejo que não tem parentesco com o conhecimento, que o conhecimento não é guiado pela necessidade interna do que é conhecido, que atrás do sujeito que conhece se desenrola a luta dos instintos, de "eus" parciais, de violências e de $\operatorname{desejos}^{297}$.

A empreitada nietzschiana, entretanto, ressalta Foucault, corre sérios riscos de se tornar precária. Afinal, problematiza Foucault:

como é possível conhecer esse outro lado, esse exterior do conhecimento? Como conhecer o conhecimento fora do conhecimento? É preciso supor uma verdade fora do conhecimento sobre a qual poderíamos nos apoiar para definir do exterior os limites do conhecimento? Mas esta verdade, como poderíamos ter acesso a ela senão a partir desse conhecimento do qual é preciso sair? ${ }^{298}$

E o filósofo, então, conclui:

Ou bem o que dizemos sobre o conhecimento é verdadeiro, mas isso só pode ser do interior do conhecimento. Ou bem falamos de fora do conhecimento, mas nada permite afirmar que aquilo que dizemos é verdade ${ }^{299}$.

Uma investigação sobre o que está fora do conhecimento, no entanto, pode não ser tão arriscada como imaginamos à primeira vista; pode ser que os problemas elencados acima pelo próprio Foucault não passem de falsos problemas.

Ao retomar Nietzsche, a primeira tarefa de Foucault será, então, a de mostrar que não é contraditório conhecer o desejo de conhecer fora da lei do conhecimento. Neste contexto, vale notar que o título dado por Foucault à aula sobre Nietzsche, no Canadá, em abril de 71, não esconde a importância de tematizar essa aparente dificuldade. A aula, que retomaremos a seguir, se intitula: "Como pensar a história da verdade com Nietzsche, sem se apoiar na verdade".

A aula proferida em Montreal consiste numa das mais longas considerações de Foucault sobre Nietzsche às quais temos acesso. Ao lado do famoso artigo "Nietzsche, a genealogia, a história", também de 71, que, de acordo com Defert, é um coroamento dos cursos que Foucault dera sobre Nietzsche desde $1967^{300}$, e do artigo "Nietzsche, Freud e Marx”, de 75, a aula do Canadá é, então, sem dúvida uma importante fonte sobre as teses foucaultianas acerca de Nietzsche.

É certo que Foucault se deteve em Nietzsche nas aulas do primeiro curso no Collège de France, afinal é ele mesmo quem dá o nome de $A$ vontade de saber ao curso e que anuncia o resgate de Nietzsche. As anotações de uma ouvinte do curso confirmam que Foucault tenha tratado de Nietzsche de maneira mais detalhada, principalmente na segunda e na última aula. Contudo não

\footnotetext{
${ }^{297}$ Cf. Foucault, Leçons sur la volonté de savoir, p. 26.

${ }^{298}$ Foucault, Leçons sur la volonté de savoir, p. 26.

299 Ibidem.

${ }^{300}$ Cf. Defert, op. cit., p. 264.
} 
consta nos manuscritos de Foucault as partes em que ele teria discorrido mais longamente sobre o filósofo alemão ${ }^{301}$; o que temos sobre Nietzsche na edição do curso são somente indicações e teses pouco desenvolvidas. Cabe a nós, portanto, saber aproveitar essas indicações e teses. É o que procuraremos fazer, retomando-as sempre à luz dos demais escritos de Foucault sobre Nietzsche, assim também como à luz dos textos do próprio Nietzsche.

Dizíamos, então, acima, que, ao retomar Nietzsche, a primeira tarefa de Foucault era a de mostrar que não é contraditório conhecer o desejo de conhecer fora da lei do conhecimento. Já na aula do dia 16 de dezembro de 1970, Foucault indica que para não se cair no paradoxo de uma verdade ao mesmo tempo desconhecida e impossível de ser conhecida (uma verdade que, por estar fora do conhecimento, é desconhecida e não pode ser conhecida, mas que seria conhecida ao passo que seria dita verdade), seria preciso tratar a verdade e o conhecimento como duas coisas independentes uma da outra. É, pois, explica Foucault, só quando verdade e conhecimento não pertencem um ao outro que se pode passar ao outro lado do conhecimento e continuar falando em verdade e em conhecimento, sem cair em contradição. Isso porque, quando não há identidade entre verdade e conhecimento, é possível pensar um conhecimento que não seja conhecimento da verdade, assim como uma verdade que não depende do conhecimento para ser alcançada. Sobre Nietzsche, então, Foucault conclui:

Creio que toda a análise nietzschiana do desejo, do instinto, da vontade de conhecer, irredutíveis ao conhecimento, é acompanhada [dublée] pelo trabalho que permite desimplicar verdade e conhecimento; assim como a redução aristotélica do desejo de conhecer o conhecimento mostra, em surdina, o parentesco entre o conhecimento e a verdade ${ }^{302}$.

Mas como exatamente Nietzsche realiza esse trabalho de desimplicar verdade e conhecimento? Na aula sobre Nietzsche proferida em Montreal em abril de 71, Foucault dá uma explicação sobre isso:

O conhecimento é feito para ser conhecimento da verdade. Há um pertencimento de origem entre a verdade e o conhecimento. E esse pertencimento é tal que: a verdade é objeto do conhecimento, o conhecimento sem verdade não é o conhecimento verdadeiro, a verdade é a verdade do conhecimento. A desenvoltura de Nietzsche foi de ter desfeito estas implicações. E de ter dito: a verdade sobrevém ao conhecimento sem que o conhecimento seja destinado à verdade, sem que a verdade seja a essência do conhecer. A primeira desenvoltura de Nietzsche foi ter dito: nem o homem, nem as coisas, nem o mundo são feitos para o conhecimento; o conhecimento sobrevém, precedido por nenhuma cumplicidade, garantido por nenhum poder. Ele sobrevém, emergindo do que lhe é outro. A segunda desenvoltura de Nietzsche foi ter dito: o conhecimento não foi feito para a verdade. A verdade sobrevém, precedida pelo não-verdadeiro, precedida antes por alguma coisa que não podemos dizer nem que é verdadeira, nem que é não verdadeira, já que é anterior à divisão própria da verdade. A verdade emerge daquilo que está fora da divisão do verdadeiro ${ }^{303}$.

\footnotetext{
${ }^{301}$ Cf. Foucault, Leçons sur la volonté de savoir, p. 28.

302 Foucault, Leçons sur la volonté de savoir, p. 27.

${ }^{303}$ Idem, p. 200.
} 
Na última aula do curso no Collège de France, dia 17 de março de 1971, Foucault volta a Nietzshce e afirma que seu curso havia sido uma tentativa de testar a "utilizabilidade" do modelo nietzschiano da vontade de saber. E o filósofo nos dá mais uma explicação desse modelo:

O modelo nietzschiano quer, ao contrário [do de Aristóteles], que a Vontade de saber reenvie a outra coisa que não ao conhecimento, que atrás da Vontade de saber haja não um tipo de conhecimento anterior que seria como a sensação, mas o instinto, a luta, a Vontade de poder. O modelo nietzschiano pretende, além disso, que a Vontade de saber componha ilusões, fabrique mentiras, acumule erros, se mova num espaço de ficção onde a verdade só seria um efeito. Ele quer, ainda, que a Vontade de saber não seja dada sob a forma da subjetividade e que o sujeito seja simplesmente uma espécie de produto da Vontade de saber, no duplo jogo da Vontade de poder e da Verdade. Enfim, para Nietzsche, a Vontade de saber não supõe a anterioridade de um conhecimento já-lá; a verdade não é dada de antemão; ela é produzida como um acontecimento ${ }^{304}$.

E desse modelo nietzschiano, Foucault tira alguns princípios que servirão de guia para suas próprias análises:

$1^{\circ} \mathrm{O}$ princípio de exterioridade que afirma que por trás do saber há outra coisa que não o saber;

$2^{\circ} \mathrm{O}$ princípio da ficção que afirma que a verdade não passa de um efeito da ficção e do erro;

$3^{\circ} \mathrm{O}$ princípio da dispersão que mostra que não é um sujeito que porta a verdade, mas que a verdade passa por uma multiplicidade de acontecimentos que a constituem ${ }^{305}$;

$4^{\circ} \mathrm{O}$ princípio do acontecimento que preconiza que a verdade é produzida como um acontecimento.

É, contudo, somente na aula proferida em abril de 71, no Canadá, que Foucault discorre mais detalhadamente sobre o modelo nietzschiano da vontade de saber. E será a partir de uma passagem de um texto de Nietzsche que nosso autor retomará os quatro princípios do modelo nietzschiano da vontade de saber, elencados acima.

A aula começa com as primeiras palavras de Sobre verdade e mentira, de 1873, de Nietzsche:

Em algum remoto recanto do universo, que se deságua fulgurantemente em inumeráveis sistemas solares, havia uma vez um astro, no qual animais astuciosos inventaram o conhecimento. Foi o minuto mais audacioso e hipócrita da "história universal"306.

Esse texto foi escrito, lembra Foucault, em pleno neokantismo e ataca, porém, não somente Kant, com a ideia de que o conhecimento é uma faculdade, mas também Hegel e sua concepção de história universal (Weltgeschichte).

\footnotetext{
${ }^{304}$ Foucault, Leçons sur la volonté de savoir, p. 190.

${ }^{305} \mathrm{Na}$ aula de 16 de dezembro, no Collège de France, encontramos valiosas pistas de como isso se dará. De acordo com Foucault, é graças ao "positivismo de Nietzsche", à utilização de saberes provenientes das ciências, como biologia, história e filologia, que o filósofo alemão investiga os acontecimentos exteriores ao conhecimento que o constituem (Cf. Foucault, Leçons sur la volonté de savoir, p. 27).
} 
Como sugere Defert, porém, a escolha estratégica desse trecho de Nietzsche pode ter como alvo Husserl e sua concepção de origem ${ }^{307}$. Husserl, em A origem da geometria, aproxima a história da ciência de uma reflexão epistemológica ou fenomenológica sobre os fundamentos originários ( $a$ priori e universais) do saber. Sobre a origem ou história da geometria, Husserl, por exemplo, afirma: "O problema da explicação histórica autêntica coincide, na ciência, com aquele da fundação e da elucidação "epistemológica"’308. Vimos, por outro lado, que a genealogia nietzschiana, apesar de ser uma pesquisa histórica sobre a gênese, não se interessa pela origem (Erfinfung), mas pela proveniência (Herkunft) e emergência (Entstehung); ou seja, não se pergunta por nenhum tipo de fundamento, seja ele lógico, epistemológico, psicológico ou biológico. Assim, se Nietzsche afirma que o conhecimento é uma invenção, que fique claro que não se trata de relacionar essa invenção a nenhum "modelo teológico e estético da criação (com sua transcendência, todo o jogo de suas originalidades e de suas invenções)"309. Não. Compreender o conhecimento como uma invenção não é compreendê-lo como uma criação divina ou como obra de um gênio. Para Nietzsche, assim como para Foucault, não interessam os fundamentos, sejam eles divinos ou humanos.

Como, então, entender a invenção do conhecimento sem que seja por um retorno a algum tipo de fundamento?

A nosso ver, essa é a grande questão a que Foucault deve responder no interior da discussão sobre a vontade de saber em Nietzsche. Assim, levando em consideração o que já falamos sobre Nietzsche, podemos dizer que afirmar que o conhecimento seja uma invenção significa dizer que ele possui uma emergência e uma proveniência; essa emergência e proveniência, contudo, não devem ser procuradas do lado do próprio conhecimento, mas, ao contrário, devem ser buscadas numa multiplicidade de acontecimentos exteriores ao sujeito que conhece. Retomando os quatro princípios norteadores da empreitada nietzschiana, podemos dizer, então, que afirmar que o conhecimento é uma invenção significa ao menos 4 coisas diferentes:

1) significa que sua proveniência e emergência estão situadas no domínio exterior ao próprio conhecimento;

2) significa perceber que o conhecimento é uma criação, uma ficção;

3) que essa criação não se funda em um sujeito soberano;

4) que essa criação se dá em função de uma multiplicidade de acontecimentos.

\footnotetext{
${ }^{307}$ Cf. Foucault, Leçons sur la volonté de savoir, p. 210, n. 3.

308 Husserl, L'origine de la géométrie, p. 205-6.

${ }^{309}$ Foucault, A arqueologia do saber, p. 193.
} 
Foucault explica com suas próprias palavras na aula sobre Nietzsche:

Que o conhecimento seja uma invenção significa que ele não está inscrito na natureza humana, que ele não consiste no mais velho instinto do homem. Mas, sobretudo, que sua possibilidade não é definida por sua própria forma. A possibilidade do conhecimento não é uma lei formal; ela encontra sua possibilidade num espaço de jogo onde está em questão outra coisa que ele mesmo, ou seja: os instintos e não a razão, o saber e a experiência; a dúvida, a negação, a dissolução, a temporização e não a afirmação, a certeza, a conquista e a serenidade. "Não há 'instinto de conhecimento'; o intelecto está a serviço de diversos instintos". O que há por trás do conhecimento é o outro, o que lhe é estrangeiro, opaco, irredutível. O conhecimento não se precede a si mesmo; ele é sem anterior, sem antecipação secreta. Atrás do conhecimento, o muro do não-conhecimento ${ }^{310}$.

Pensando na oposição proposta por Foucault entre o modelo da vontade de saber em Aristóteles e Nietzsche, procuraremos esclarecer o paradigma do modelo nietzschiano retomando essencialmente dois aspectos levantados por Foucault no que tange à concepção de conhecimento em Nietzsche. Como veremos, esses aspectos apontam para os textos de Nietzsche que, a meu ver, são centrais para compreendermos o paradigma nietzschiano da vontade de saber que desimplica conhecimento e verdade: $O$ nascimento da tragédia (1871), Sobre verdade e mentira no sentido extra-moral (1873), A Gaia Ciência (1882-1887), Além do bem e do mal (1885-1886) e Genealogia da moral (1887).

Não é tarefa fácil circunscrever os textos de Nietzsche que tiveram mais influência sobre Foucault, pois além de nosso autor fazer referências a inúmeros escritos do filósofo alemão, nós mesmo poderíamos encontrar ao longo da vasta obra de Nietzsche diversos pontos que estão em sintonia com o pensamento de Foucault.

De acordo com Daniel Defert, num curso dado na Universidade de Vincennes, durante o inverno de 1969-1970, Foucault teria sublinhado que só seria a partir de $O$ nascimento da tragédia que encontramos uma teoria sobre a vontade de saber (Wissensgier) em Nietzsche ${ }^{311}$. Nesse sentido, esse livro deveria ser essencial para compreendermos o paradigma nietzschiano da vontade de saber. Por outro lado, Defert também sugere que o ponto de partida para a reflexão de Foucault em seu primeiro curso do Collège de France fora o texto nietzschiano de 1873, Sobre verdade $e$ mentira no sentido extra-moral, que em 1969 havia sido publicado em francês graças à tradução de sua amiga filósofa Angèle Kremer-Marietti ${ }^{312}$. No resumo desse mesmo curso, porém, ao falar de Nietzsche, Foucault cita $A$ gaia ciência ${ }^{313} \mathrm{e}$ nas notas preparatórias ao curso parece se referir somente a Humano, demasiado humano ${ }^{314}$. Na aula sobre Nietzsche proferida no Canadá, por fim,

\footnotetext{
${ }^{310}$ Foucault, Leçons sur la volonté de savoir, pp. 195-6.

${ }^{311}$ Defert, op. cit., p. 264.

312 Cf. Defert, op. cit., p. 266.

${ }^{313}$ Cf. Foucault, "Resume”, in Leçons sur la volonté de savoir, p.219.

${ }^{314}$ Cf. Foucault, Leçons sur la volonté de savoir, p.29, n. 4.
} 
além de A gaia ciência, Foucault retoma também passagens de Aurora, Além do bem e do mal, Genealogia da moral e principalmente de $A$ vontade de poder.

Como se pode ver, não é tão simples retraçar a leitura foucaultiana de Nietzsche. Se fôssemos resgatar cada referência direta ou indireta ao filósofo alemão, esse trabalho correria o risco de se tornar um estudo (aliás, um mau estudo, já que superficial) sobre Nietzsche, antes que um estudo sobre Foucault. Visto, então, que o que nos interessa é o uso que Foucault faz de Nietzsche, mais do que o próprio Nietzsche, achamos que o mais prudente é identificar os temas nietzschianos que, a nosso ver, são mais relevantes, eficazes e estratégicos para Foucault. Como já dissemos, retomaremos dois aspectos levantados por Foucault no que tange à concepção de conhecimento em Nietzsche a fim de compreender de que modo o paradigma nietzschiano da vontade de saber desimplica conhecimento e verdade. O primeiro deles é sobre o tema da exterioridade do conhecimento. O segundo aspecto é sobre o conhecimento como interpretação.

\section{A exterioridade do conhecimento em Nietzsche}

De acordo com Foucault, o que há fora do conhecimento, para Nietzsche, é "um mundo de relações que em si mesmas não são conhecidas"315; "mundo informe e informulável do caos da sensação"316.

Esse mundo de relações se compõe basicamente de relações de forças, isto é, de relações violentas: relações de destruição, apropriação, dominação, punição ${ }^{317}$. Poderíamos também chamar de impulso ou de desejo essas relações violentas informuláveis que se dão entre um corpo e outro corpo, um indivíduo e uma coisa, um animal ou deus, ou mesmo as que se dão entre um grupo de pessoas e outro grupo ${ }^{318}$. Ora, é a esse mundo de relações que Nietzsche dá o nome de vontade de potência. Mas, que não nos enganemos quanto ao termo vontade. Em nada ele tem a ver com a vontade livre de um sujeito soberano. Esta vontade é, antes, o nome dado a um "sistema real de dominação"319, diz Foucault. É certo que esse "sistema real de dominação" tem seu ponto de apoio

\footnotetext{
315 Foucault, Leçons sur la volonté de savoir, p. 202. antropomoerfismos estéticos".

317 Cf. Foucault, Leçons sur la volonté de savoir, p. 203.

318 Foucault, Leçons sur la volonté de savoir, p. 203.

${ }^{319}$ Cf. Foucault, Leçons sur la volonté de savoir, p. 6.
}

316 Nietzsche apud Foucault, Leçons sur la volonté de savoir, p. 202. Sobre o mundo como um caos ver ainda $A$ gaia ciência, § 109: “O caráter geral do mundo [...] é o caos por toda a eternidade, não no sentido de ausência de necessidade, mas de ausência de ordem, divisão, forma, beleza, sabedoria e como quer que se chame nossos 
em um sujeito, contudo, ele não se refere a uma faculdade racional do sujeito, mas, ao contrário, aos seus impulsos inconscientes. Assim, que estejamos previnidos contra uma possível objeção formulada pelo próprio Foucault no início do curso sobre a vontade de saber: "é razoável para uma análise dos saberes que tenta não se referir a um sujeito fundador ter como noção central a vontade? Essa não seria outra maneira de reintroduzir novamente alguma coisa como um sujeito soberano?"320.

Ainda não sabemos o que exatamente Foucault entende por vontade de saber, entretanto, já é possível antecipar que do mesmo modo que em Nietzsche a vontade de poder não diz respeito a uma faculdade racional de um sujeito soberano, tampouco em Foucault a noção de vontade aponta para esse sentido. Por ora fiquemos com Nietzsche.

Dizíamos, então, que fora do domínio do conhecimento o que existe são impulsos e relações violentas entre esses impulsos. O conhecimento, por seu turno, se constituirá como efeito dessas relações, assim como a verdade. A verdade, portanto, não é aquilo que precede o conhecimento e o que ele deve apreender. A verdade é uma construção e ela é justamente construída pela operação que chamamos conhecer.

Assim, diferentemente de Aristóteles que crê na naturalidade, na serenidade e no prazer do conhecimento, para Nietzsche o conhecimento é sempre o resultado de uma operação violenta, exaustiva e sofrida. Não há instinto de conhecimento, talvez como possa acontecer em Aristóteles. Para Nietzsche, ao contrário, “o intelecto está a serviço de diversos instintos" ${ }^{2} 21$. Sobre isso, o $§ 333$ (“O que significa conhecer?”) de A gaia ciência é bastante elucidativo. Diz Nietzsche ao comentar a máxima de Espinosa “Non ridere, non lugere, neque detestari, sed intelligere!” (Não rir, não lamentar, nem detestar, mas compreender! ${ }^{322}$ ):

\begin{abstract}
achamos que intelligere é algo conciliatório, justo, bom, essencialmente contrário aos impulsos; enquanto é apenas uma certa relação dos impulsos entre si. Por longo período o pensamento consciente foi tido como o pensamento em absoluto: apenas agora começa a raiar para nós a verdade de que a atividade de nosso espírito ocorre, em sua maior parte, de maneira inconsciente e não sentida por nós; mas eu penso que tais impulsos que lutam entre si sabem muito bem fazer-se sentidos e fazer mal uns aos outros: - a violenta e súbita exaustão que atinge todos os pensadores talvez tenha aí a sua origem (é a exaustão do campo de batalha) ${ }^{323}$.
\end{abstract}

\footnotetext{
${ }^{320}$ Foucault, Leçons sur la volonté de savoir, p. 5.

${ }^{321}$ Nietzsche apud Foucault, Leçons sur la volonté de savoir, p. 196.

322 Ao que tudo indica, Nietzsche se refere aqui à seguinte passagem do Tratado político de Espinosa: "no deduzir do estudo da natureza humana e, para contribuir para este estudo com a mesma liberdade de espírito que é costume contribuir para as investigações matemáticas, tive todo o cuidado em não ridicularizar as ações dos homens, não as lamentar, não as detestar, mas adquirir delas verdadeiro conhecimento" (Espinosa, Tratado político, p. 314).
} 
Mas, como compreender o conhecimento como resultado de "uma certa relações dos impulsos entre si"? A nosso ver, Foucault procura responder a essa questão a partir de duas oposições contrárias entre um conhecimento que quer a verdade e um conhecimento que não se interessa por ela.

De acordo com Foucault, o conhecimento que não se dirige à verdade aparece em Nietzsche com dois sentidos diferentes: "o conhecimento anterior à verdade é definido tanto como o conhecimento violento e maldoso do segredo, a profanação que desvenda, quanto o conhecimento violento e útil que serve à vida; a parcialidade que permite dominar e crescer" 324 . Para explicar a exterioridade do conhecimento Foucault, então, resgatará esses dois tipos de conhecimento que não se interessam pela verdade. Ambos serão apresentados em contraposição a outros tipos de conhecimentos que, esses sim, querem a verdade.

O conhecimento profano e inútil, o conhecimento trágico, contrapõe-se ao conhecimento teórico encarnado pela figura de Sócrates; o conhecimento violento e útil que serve à vida, conhecimento primordial e corporal, por seu turno, contrapõe-se ao conhecimento ascético inútil. E vale notar que se no primeiro sentido o conhecimento que não se direciona à verdade é inútil, no segundo sentido ele é útil. O conhecimento trágico é inútil em oposição ao conhecimento teórico que vê utilidade prática ou teórica na apreensão da verdade. O conhecimento corporal, por outro lado, é útil não porque alcança a verdade, mas porque serve à conservação da vida; ele se contrapõe, portanto, à inutilidade do conhecimento ascético que quer simplesmente a verdade sem se preocupar se ela promove ou não a vida. Expliquemos.

\section{Conhecimento trágico $x$ conhecimento teórico}

Em primeiro lugar, em oposição a um conhecimento que quer a verdade, há um tipo de conhecimento profano e transgressor que quer mais o mistério e o obscuro do que a verdade: "conhecimento que se estende no domínio do segredo, do interdito, do desvendamento, da transgressão", diz Foucault ${ }^{325}$. Em oposição ao conhecimento que se pretende ser um bom conhecimento, utilitário, generoso e que faz o bem, que sente a necessidade de sistematizar, organizar e esquematizar, este outro tipo de conhecimento é inútil, está ligado a um sentimento de maldade e ao invés de querer a aparência e a simplificação como o conhecimento que se dirige à

\footnotetext{
${ }^{324}$ Foucault, Leçons sur la volonté de savoir, p. 201.

325 Ibidem.
} 
verdade, o conhecimento profano quer apreender as coisas em sua profundidade e a multiplicidade de suas essências.

É provavelmente às seguintes linhas de Além do bem e do mal que Foucault se refere ao retomar essa oposição:

\begin{abstract}
Esse imperioso algo a que o povo chama "espírito" quer ser e quer se sentir senhor, dentro e em torno de si: tem a vontade de conduzir da multiplicidade à simplicidade, uma vontade restritiva, conjuntiva, sequiosa de domínio e realmente dominadora [...]. A força que tem o espírito, de apropriar-se do que lhe é estranho, manifesta-se num forte pendor a assimilar o novo ao antigo, a simplificar o complexo, a rejeitar ou ignorar o inteiramente contraditório: do mesmo modo ele arbitrariamente sublinha, destaca e ajeita para si determinados traços e linhas do que lhe é estranho, de cada fragmento de "mundo exterior". [...] A serviço dessa mesma vontade se acha também um impulso aparentemente oposto ao espírito, uma brusca decisão de não saber, de encerrar-se voluntariamente, um fechamento das janelas, um dizer Não interiormente a essa ou aquela coisa conhecível, uma satisfação com o obscuro, com o horizonte que se fecha, um acolhimento e aprovação da insciência: tudo isso necessário, conforme o grau de sua força apropriadora, de sua "força digestiva", usando uma imagem [...]. Contra essa vontade de aparência, de simplificação, de máscara, enfim, de superfície - pois toda superfície é um manto -, atua aquele sublime pendor do homem de conhecimento, ao tomar e querer tomar as coisas de modo profundo, plural, radical: como uma espécie de crueldade da consciência e do gosto intelectuais, que todo pensador valente reconhecerá em si $[\ldots]^{326}$.
\end{abstract}

O conhecimento transgressor para Nietzsche não é, portanto, da ordem da conciliação, da justiça e da bondade; não é da ordem da aprovação, do amor, da adoração, do prazer e da felicidade. Muito pelo contrário: ele é fruto da maldade. “[...] em todo querer-conhecer já existe uma gota de crueldade", afirma Nietzsche em Além do bem e do mal ${ }^{327}$. Esse é, pois, o sentido mais forte de sua violência. Antes de ser um movimento natural que se apropria das coisas com adoração, o conhecimento transgressor consiste num movimento que procura se afastar delas. O riso é uma proteção contra elas; desvalorizá-las é um modo de se diferenciar delas; detestá-las é uma maneira de destruí-las. "O conhecimento não é nem da ordem da omoiesis [assimilação], nem da ordem do bem”, conclui Foucault ${ }^{328}$. Ao contrário disso. É um conhecimento que sabe que tudo não passa de aparência e ilusão e que, portanto, procura destruir as coisas com crueldade, colocando-as em questão, arrancando seus segredos. Este trabalho, contudo, não é recompensado com o acesso ao ser ou à essência, mas suscita novas aparências e ilusões. Sendo assim, é um conhecimento que se dá sempre em perspectiva e que nunca se completa ${ }^{329}$.

A oposição retomada por Foucault entre o conhecimento profano e o conhecimento do bem parece ser também aquela indicada por Nietzsche em $O$ nascimento da tragédia. Nesse livro de 1870-71, Nietzsche opõe dois tipos de conhecimento: o trágico e o teórico.

\footnotetext{
${ }^{326}$ Nietzsche, Além do bem e do mal, § 230, pp. 122-124.

${ }^{327}$ Idem, § 229, p. 122.

${ }^{328}$ Foucault, Leçons sur la volonté de savoir, p. 197.

${ }^{329}$ Idem, p. 198.
} 
Neste livro, Nietzsche procura compreender donde vem o anseio de beleza e de feiúra que aparecem reunidas nas tragédias gregas. De um lado, a festa, a dança e a beleza; de outro lado, a dor e o sofrimento. E para o filósofo alemão elas vêm da comunhão entre dois impulsos artísticos contrários: o impulso dionísíaco e o impulso apolíneo.

A seus dois deuses da arte, Apolo e Dionísio, vincula-se a nossa cognição de que no mundo helênico
existe uma enorme contraposição, quanto as origens e objetivos, entre a arte do figurador plástico
[Bildner], a apolínea, e a arte não-figurada [unbildlichen] da música, a de Dionísio: ambos os
impulsos [Trieb], tão diversos, caminham lado a lado, na maioria das vezes em discórdia aberta e
incitando-se mutuamente a produções sempre novas [...]; até que, por fim, através de um miraculoso
ato metafísico da "vontade" helênica, aparecem emparelhados um com o outro, e nesse
emparelhamento tanto a obra de arte dionisíaca quanto a apolínea geraram a tragédia ática. ${ }^{330}$

Os impulsos dionisíacos e apolínios são descritos por Nietzsche como impulsos artísticos da natureza. Entretanto, tais impulsos não servem de princípio somente às produções da arte, como a música, as artes plásticas e a tragédia; eles estão por trás não só do modo de pensar artístico, mas também do científico e filosófico. Podemos então dizer que o impulso dionisíaco é o impulso propriamente artístico, já que é ele que fornece a força e a violência da experiência; o impulso apolíneo, por seu turno, está mais do lado do que Nietzsche chama de impulso lógico ou científico, uma vez que é ele o responsável pela ordenação do mundo caótico de Dionísio.

Assim, no que diz respeito ao modo como os homens se relacionam em geral com o mundo, podemos destacar duas maneiras distintas de pensar e conhecer o mundo. A primeira delas é guiada pelo impulso dionisíaco e o pensamento ou conhecimento do artista e do herói; a segunda maneira de se relacionar com o mundo é a do homem teórico (ou seja, Sócrates), que é guiada pelo impulso apolíneo. Em $O$ nascimento da tragédia, é da seguinte maneira que Nietzsche descreve como cada uma dessas figuras lida com o conhecimento:

Se com efeito o artista, a cada desvelamento da verdade, permanece sempre preso, com olhares extáticos, tão-somente ao que agora, após a revelação, permanece velado, o homem teórico se compraz e se satisfaz com o véu desprendido e tem o seu mais alto alvo de prazer no processo de um desvelamento cada vez mais feliz $[\ldots]^{331}$.

De um lado, com a figura do homem teórico, há um pretenso conhecimento verdadeiro, aquele que não se cansa pela busca da verdade, aquele que crê, com as palavras de Nietzsche, "que o pensar, pelo fio condutor da causalidade, atinge até os abismos mais profundos do ser e que o pensar está em condições, não só de conhecê-lo, mas inclusive de corrigi-lo" ${ }^{332}$; o conhecimento de Sócrates que é o "protótipo do otimista teórico que, já na assinalada fé na escrutabilidade da natureza das coisas, atribui ao saber e ao conhecimento a força de uma medicina universal e percebe

\footnotetext{
${ }^{330}$ Nietzsche, $O$ nascimento da tragédia, p. 27.

331 Idem, p. 92.

332 Idem, p. 93.
} 
no erro o mal em si mesmo"333. De outro lado, há um tipo de conhecimento que, no fim das contas, nem deveria ser chamado de conhecimento, já que se satisfaz com o mistério, com o obscuro, com aquilo que não pode ser esclarecido: o conhecimento trágico dos heróis e dos artistas. De um lado, o conhecimento guiado pelo que Nietzsche chama de instinto à ciência ${ }^{334}$, de impulso lógico ${ }^{335}$ ou ainda de impulso apolíneo. Apolo, lembra Nietzsche, é o deus da luz ${ }^{336}$; o impulso apolíneo, portanto, é aquele que leva o homem a buscar uma ordem inteligível para o mundo, que funciona como princípio de individuação das coisas e que nos leva a ver o mundo pelo véu da aparência e da beleza. De outro lado, o conhecimento guiado pelo impulso dionisíaco que, mais do que a experiência da beleza e da individuação, proporciona a experiência do terror e do êxtase tal como se estivéssemos embriagados; experiência que se dá ali onde o princípio da razão e de individuação parecem sofrer uma excessão e onde há desvanecimento completo do subjetivo ${ }^{337}$.

Para Foucault, como lembra Daniel Defert, o tema da vontade de saber aparece em Nietzsche justamente a partir de 1871, com O nascimento da tragédia. Apesar da centralidade que esta obra poderia ter aos olhos de Foucault no que tange ao tema de seu interesse, o filósofo francês pouco fala dela. No curso Leçons sur la volonté de savoir, por exemplo, na primeira aula, sobre Aristóteles, nosso autor parece indiretamente fazer referência à obra de Nietzsche ao tematizar o saber trágico dos heróis.

Em oposição à vontade de saber de Aristóteles, para quem o conhecimento vai do prazer à felicidade por meio de um movimento natural, o saber dos heróis aparece como alguma coisa que se constrói por meio de uma luta situada no exterior do próprio conhecimento. Em contraposição ao saber dos heróis, é como se Aristóteles simplificasse demais a nossa relação com o saber. Para Aristóteles, o saber não se dá por caminhos tortuosos que devem ser arduamente percorridos. Muito pelo contrário: o conhecimento é alcançado naturalmente, sem esforço nenhum. Basta abrir os olhos e ver. A natureza de nossas sensações seria tal que ela espontaneamente se dirigiria ao conhecimento das causas e das essências. Totalmente diferente seria, aos olhos de Foucault, o saber trágico dos heróis.

Esse saber, diz Foucault, parece sempre nascer de um enigma, de uma palavra profética, "pronunciada de longe e do alto", palavra que ao mesmo tempo acalma e inquieta, que é e não é

\footnotetext{
${ }^{333}$ Nietzsche, O nascimento da tragédia, p. 94.

334 Idem, p. 93.

335 Idem, p. 86.

336 Idem, p. 29.

${ }^{337}$ Idem, p. 30.
} 
compreendida $^{338}$. Longe do conhecimento sereno e apaziguador de Aristóteles, que é um saber claro e imediato, o saber dos heróis é um saber obscuro e prometido que muitas vezes quando é conquistado e decifrado, coincide com a morte e a destruição. É o que Nietzsche parece querer dizer ao afirmar que o conhecimento trágico leva à desintegração da natureza e de si mesmo: "a sabedoria dionisíaca, é um horror antinatural, que aquele que por seu saber precipita a natureza no abismo da destruição há de experimentar também em si próprio a desintegração da natureza" "339. Esse é, pois, de acordo com Nietzsche, o caso de Édipo. Édipo, o decifrador do enigma da Esfinge, que força a natureza a entregar os seus segredos, destruindo-a, é também aquele que destrói a si próprio, que transgride as mais sagradas ordens da natureza inscritas em si mesmo: mata o pai e esposa a mãe. Arremata Nietzsche: “o aguilhão da sabedoria se volta contra o sábio; a sabedoria é um crime contra a natureza" 340 .

Assim, se por um lado o saber teórico ou apolínio nos põe em contato com um mundo organizado, ordenado pelo véu das aparências e pela máscara da individuação, o saber trágico ou dionisíaco nos coloca diante de um mundo caótico, desordenado e desfigurado. Esta parece ser, pois, a conclusão de Nietzsche no final de $O$ nascimento da tragédia. Os heróis trágicos até Eurípedes, afirma Nietzsche, "são tão-somente máscaras daquele proto-herói, Dionísio. [...] Dionísio sofredor, dos Mistérios, aquele deus que experimenta em si os padecimentos da individuação, a cujo respeito mitos maravilhosos contam que ele, sendo criança, foi despedaçado pelos Titãs" ${ }^{341}$. É, então, Dionísio o verdadeiro protagonista das tragédias gregas, pois é ele que aponta para o aniquilamento do indivíduo, para o disforme, o feio, para os "temores e horrores do existir"342, para os "horrores da existência individual" ${ }^{443}$, enfim, para "o abismo mais íntimo das coisas" 344 .

\footnotetext{
${ }^{338}$ Cf. Foucault, Leçons sur la volonté de savoir ,p. 15

${ }^{339}$ Nietzsche, O nascimento da tragédia, p. 65.

${ }^{340}$ Ibidem.

${ }^{341}$ Idem, p. 70.

${ }^{342}$ Idem, p. 36.

${ }^{343}$ Idem, p. 102.

${ }^{344}$ Idem, p. 125.
} 
Esse conhecimento trágico e transgressor que mais destrói do que possui as coisas, é o primeiro sentido que Nietzsche, segundo Foucault, dá ao conhecimento que não quer a verdade. $\mathrm{O}$ conhecimento do que está além da verdade e da falsidade, entretanto, também é entendido por Nietzsche como conhecimento corporal e primário. Neste âmbito, o conhecimento é comandado pela necessidade, pela luta, pela vida, pela caça, pela alimentação, pela rivalidade. Enfim, é um conhecimento imediatamente articulado com a conservação da vida e, portanto, com a necessidade de sobrevivência ${ }^{345}$. Neste contexto, afirma Nietzsche em A gaia ciência (§ 110): “a força do conhecimento não está no seu grau de verdade, mas na sua antiguidade, no seu grau de incorporação, em seu caráter de condição para a vida"346. Retomo aqui também a passagem de Nietzsche em a A vontade de poder, § 192, citada por Foucault: “Todos nossos órgãos de conhecimento e nossos sentidos só se desenvolvem a serviço de nossa conservação e nosso crescimento" 347 .

Podemos ainda citar uma importante passagem de A gaia ciência (§ 111), onde Nietzsche afirma que a sistematização e logicização do mundo respondem, a princípio, a uma necessidade de conservação. Explica o filósofo:

De onde surgiu a lógica na mente humana? Certamente do ilógico, cujo domínio deve ter sido enorme no princípio. Mas incontáveis outros seres, que inferiam de maneira diversa da que agora inferimos, desapareceram: e é possível que ela fosse mais verdadeira! Quem, por exemplo, não soubesse distinguir com bastante freqüência o "igual" no tocante à alimentação ou aos animais que lhe eram hostis, isto é, quem subsumisse muito lentamente, fosse demasiado cauteloso na subsunção, tinha menos probabilidades de sobrevivência do que aquele que logo descobrisse igualdade em tudo o que era semelhante. [...] Do mesmo modo, para que surgisse o conceito de substância, [...] por muito tempo foi preciso que o que há de mutável nas coisas não fosse visto nem sentido; os seres que não viam exatamente tinham vantagem sobre aqueles que viam tudo "em fluxo". Todo elevado grau de cautela ao inferir, toda propensão cética, já constitui em si um grande perigo para a vida. Nenhum ser vivo teria se conservado, caso a tendência oposta de afirmar antes que adiar o julgamento, de errar e inventar antes que aguardar, de assentir antes que negar, de julgar antes que ser justo - não tivesse sido cultivada com extraordinária força. - O curso dos pensamentos e inferências lógicas, em nosso cérebro atual, corresponde a um processo e uma luta entre impulsos que, tomados separadamente, são todos muito ilógicos e injustos ${ }^{348}$.

É importante, contudo, deixar claro que apesar desse conhecimento primordial e corporal consistir num esforço de sistematizar ou logicizar a natureza, ele não pode se confundir com o conhecimento teórico que busca a verdade. A utilidade desse conhecimento para a vida não está no

\footnotetext{
345 Foucault, Leçons sur la volonté de savoir, p. 201.

346 Nietzsche, A gaia ciência, p. 137.

${ }^{347}$ Foucault, Leçons sur la volonté de savoir, p. 201.

348 Nietzsche, A gaia ciência, p. 139 Podemos também lembrar do seguinte trecho de Além do bem e do mal, § 3: "Por trás de toda lógica e de sua aparente soberania de movimentos existem valorações, ou, falando mais claramente, exigências fisiológicas para a preservação de uma determinada espécie de vida" (p. 11).
} 
fato de ele apreender a verdade do mundo. Pouco lhe importa se a organização que ele dá ao mundo seja ou não verdadeira. Aliás, nota Nietzsche, é possível que haja outras maneiras de inferir sobre o mundo que sejam mais verdadeiras. Assim, antes de conhecer a verdade do mundo, o conhecimento corporal que é útil para a vida é aquele que sabe usar o mundo, é aquele que o organiza de tal modo a fim de usá-lo a favor da conservação do próprio indivíduo. E ao invés de ser um conhecimento das verdades do mundo, é um tipo de conhecimento que produz as verdades do mundo; essas verdades, contudo, não são verdadeiras. São verdades falsas, não passam de erros e de falsificações da realidade. Mas mesmo sendo erros e deformações da realidade, as verdades produzidas pelo conhecimento corporal são úteis e ajudam a conservar a espécie. Confirma Nietzsche em $A$ gaia ciência $(\S 110)$ :

Durante enormes intervalos de tempo, o intelecto nada produziu senão erros; alguns deles se revelaram úteis e ajudaram a conservar a espécie [...]. Esses equivocados artigos de fé que foram continuamente herdados, até se tornarem quase patrimônio fundamental da espécie humana, são os seguintes, por exemplo: que existem coisas duráveis, que existem coisas iguais, que existem coisas, matérias, corpos, que uma coisa é aquilo que parece; que nosso querer é livre, que o que é bom para mim também é bom em si3 ${ }^{349}$.

Dizer que a produção de certas "verdades falsas" ou erros seja útil à vida não é a mesma coisa que afirmar que o conhecimento da verdade é útil à vida. No primeiro caso, temos um processo intelectual que procura sistemarizar a realidade a fim de podermos melhor utilizar o mundo a favor da conservação da vida. Diferente desse tipo de conhecimento é o pretenso conhecimento puro e ascético que não pretende ser uma violência feita às coisas, que não pretende ser uma falsificação da realidade em vistas de sua utilização à favor da vida, mas que quer ser uma simples e tranquila apreensão da verdade.

Assim, em oposição a esse conhecimento primordial, corporal, cuja utilidade é a vida, estaria o conhecimento que, esse sim, quer a verdade; um conhecimento que é pura contemplação e que supostamente "suprime o ponto de vista do corpo, suspende a utilidade, apaga as parcialidades e os limites, quer tudo ver com um olhar neutro e sem preconceitos. Conhecimento que se quer puro" 350 . Conhecimento ascético.

Ora, dizemos que o conhecimento ascético supostamente suspende o ponto de vista do corpo, isto é, dos desejos e da utilidade, pois como temos visto, em Nietzsche, por trás de todo conhecimento há algum interesse. Sendo assim, também por trás do pretenso conhecimento puro da verdade deve haver algum interesse.

É o que sugere Nietzsche ainda em A gaia ciência (§ 110):

\footnotetext{
349 Nietzsche, A gaia ciência, p. 137.

${ }^{350}$ Foucault, Leçons sur la volonté de savoir, p. 201.
} 
Não somente utilidade e prazer, mas todo gênero de impulsos tomou partido na luta pelas "verdades"; a luta intelectual tornou-se ocupação, atrativo, dever, profissão, dignidade -: o conhecimento e a busca do verdadeiro finalmente se incluíram, como necessidade, entre as necessidades. [...] O conhecimento se tornou então parte da vida mesma e, enquanto vida, um poder em contínuo crescimento ${ }^{351}$.

O interesse que está por trás do pretenso conhecimento ascético, entretanto, não é o interesse pela conservação da vida; os impulsos que o direcionam não têm a ver com as necessidades vitais, com a fome, com a alimentação, com a sobrevivência. A violência feita ao mundo aqui não tem em vista o fortalecimento da vida; seu efeito, ao contrário, mais enfraquece do que fortalece os homens. A luta pela verdade não é uma luta que engrandece o homem, aumentando sua força vital. É uma luta baixa; tem a ver com ocupação, atrativo, dever, profissão, dignidade, e não com a própria vida. Apesar disso, diz Nietzsche, é um tipo de conhecimento dos mais difundidos e duradouros que existem $^{352}$.

$\mathrm{Na}$ terceira dissertação da Genealogia da moral, intitulada "O que significam os ideais ascéticos?", Nietzsche discorre longamente sobre o conhecimento ascético. De acordo com o filósofo, o asceta trata a vida como um caminho errado e um erro que se deve refutar; ele é hostil à vida, ao que é humano, animal, ao que é matéria, aos sentidos. Sua vontade é uma vontade de nada ${ }^{353}$. Sente desgosto "de si, da terra, de toda a vida"354; tem medo da felicidade e da beleza, da mudança, da morte, do devir, do desejo e dos anseios; nega a própria existência, deseja o seu fim e uma existência inteiramente outra. Daí o caráter contraditório da atitude e do conhecimento ascéticos: eles procuram promover a vida, colocando-se contra a vida. Explica Nietzsche:

\footnotetext{
Pois uma vida ascética é uma contradição: aqui domina um ressentimento ímpar, aquele de um insaciado instinto e vontade de poder que deseja senhorar-se, não de algo da vida, mas da vida mesma, de suas condições maiores, mais profundas e fundamentais; aqui se faz a tentativa de usar a força para estancar a fonte da força; aqui o olhar se volta rancoroso e pérfido, contra o florescimento fisiológico mesmo, em especial contra a sua expressão, a beleza, a alegria; enquanto se experimenta e se busca satisfação no malogro, na desventura, no fenecimento, no feio, na perda voluntária, na negação de si, autoflagelação e autosacrifício ${ }^{355}$.
}

Mas Nietzsche procura encontrar uma justificativa para esse "insaciado instinto e vontade de poder" que se voltam contra a vida. De acordo com o filósofo, o impulso que está por trás do conhecimento ascético é ainda um impulso de vida, "instinto de cura e proteção de uma vida que degenera" 356 . Por mais paradoxal que seja, o conhecimento ascético, que nega a vida, é ainda um

\footnotetext{
351 Nietzsche, A gaia ciência, p. 138.

352 Nietzsche, Genealogia da moral, III, § 11, p. 107.

${ }^{353}$ Idem, III, $\S 28$, p. 149.

${ }^{354}$ Idem, III, § 11, p. 107.

355 Ibidem.

${ }^{356}$ Idem, III, § 13, p. 109
} 
"artifício para a preservação da vida" 357 ; preservação de uma vida, contudo, que está doente, cansada e esgotada; uma vida que sofre com a falta de sentido; uma vida, por fim, que só vê salvação negando o corpo e mantendo no além a esperança de uma existência melhor. O instinto de cura dos "espíritos fracos", entretanto, os torna ainda mais fracos; se, por um lado, o conhecimento ascético de uma verdade do além e a vida ascética que nega a própria existência com seus prazeres e desprazeres dá um sentido ao sofrimento humano, por outro lado, torna esse sofrimento ainda pior, mais profundo e nocivo à vida. O sofrimento passa a ser interpretado como castigo aos pecados e, por conseguinte, ele gera outro sofrimento: o sofrimento ligado ao sentimento de culpa $^{358}$. Essa é a conclusão que Nietzsche expõe nas últimas linhas de Genealogia da moral:

A falta de sentido do sofrer, não o sofrer, era a maldição que até então se estendia sobre a humanidade - e o ideal ascético lhe ofereceu um sentido! [...] Nele o sofrimento era interpretado; a monstruosa lacuna [aquilo que falta ao homem] parecia preenchida; a porta se fechava para todo niilismo suicida. A interpretação - não há dúvida - trouxe consigo novo sofrimento, mais profundo, mais íntimo, mais venenoso e nocivo à vida: colocou todo sofrimento sob a perspectiva da culpa... Mas apesar de tudo o homem estava salvo, ele possuía um sentido, a partir de então não era mais uma folha ao vento, um brinquedo do absurdo, do sem-sentido, ele podia querer algo - não importando no momento para que direção, com que fim, com que meio ele queria: a vontade mesma estava salva ${ }^{359}$.

Que não se confunda o conhecimento ascético com o conhecimento trágico dos heróis. Sem dúvida ambos parecem ter certo pendor para o sofrimento, a dor, o feio; além disso, também é certo que tanto o conhecimento transgressor dos heróis quanto o conhecimento puro do asceta podem levar à desintegração do sujeito. Vimos, pois, que o impulso dionisíaco se afasta da beleza e da alegria de Apolo e, por vezes, quando é enfrentado com vivacidade, pode levar ao desfalecimento do herói. Entretanto, se, por um lado, o conhecimento trágico é aquele dos espíritos fortes que suportam o caos do mundo, sua profundidade e multiplicidade, daqueles que estão dispostos a morrer quando entram em contato com o que não pode ser conhecido, por outro lado, o conhecimento ascético é aquele dos espíritos fracos e doentes que não suportam as dores e os horrores da vida. O asceta é aquele que não tem forças para enfrentar o mundo caótico de Dionísio e precisa encontrar um sentido para esse mundo de desintegração. Esse sentido se dá na forma de uma verdade superior, uma verdade anunciada em um mundo do além e que só pode ser alcançada por meio da negação da própria vida mundana com seus impulsos dionisíacos e apolíneos.

\footnotetext{
${ }^{357}$ Nietzsche, Genealogia da moral, III, § 13, p. 110.

358 Sobre esse ponto, esclarece Carlos Alberto Ribeiro de Moura: “Com a introdução do pecado como interpretação dos fatos como novo nome da má consciência, a dor é interpretada como castigo, a nova imagem do enfermo é a de pecador, e o sofrimento adquire 'sentido' quando reportado a um mundo extranatural. O triunfo do ideal ascético, enquanto método de culpabilidade, é transformar a dor em desejo de dor, junto a um sofredor que é sempre culpado. E por isso o sacerdote ascético, apesar de representar uma contradição diante da vida, é um dos instrumentos de conservação da própria vida, já que ele consegue dar um sentido à existência escrava" (Moura, Nietzsche: civilização $e$ cultura, pp. 156-7).
}

${ }^{359}$ Nietzsche, Genealogia da moral, III, § 28, p. 149. 
Pode-se dizer que o combate vivido pelo heróis trágicos dá-se sempre no nível terreno da vida; uma luta protagonizada entre os dois impulsos artísticos da natureza, o dionisíaco e o apolíneo. E se Dionísio é o verdadeiro protagonista da tragédia, como diz Nietzsche em $O$ nascimento da tragédia, é justamente porque suporta viver aqui e agora com as dores do existir. Esse é, pois, o seu heroísmo. Ele diz Não às aparências, ao manto, às superfícies, e Sim à profundidade, à multiplicidade, ao caos. Muito diferente é o caráter do asceta. De certo modo ele também entra em contato com o sofrimento advindo do caos mundano e da falta de sentido. No entanto, ele é fraco para suportar o que não pode ser explicado; ele precisa, pois, criar um mundo, diferente desse no qual nos encontramos, onde ele possa projetar todas suas esperanças, onde ele possa, enfim, conciliar-se com um sentido, com a verdade, com a justiça e com a bondade. $\mathrm{O}$ asceta, então, é aquele que diz um Não à totalidade da vida terrena, seja ela apolínea ou dionisíaca; seu único Sim é asserida a uma vida futura, a uma verdade suprema situados num mundo do além.

Resumindo. Em Nietzsche, a exterioridade do conhecimento constituída pela força violenta dos impulsos "que serve de trama ao conhecimento e que entra em cena com o conhecimento" dá lugar a pelo menos 4 tipos de conhecimentos diferentes: o conhecimento maldoso, inútil e profano que suporta a ausência de verdade; o conhecimento corporal que não quer apreender uma verdade do mundo, mas ser utilizado à favor da vida; um conhecimento teórico que quer dominar o mundo extraindo dele a sua verdade; e, por fim, um conhecimento ascético que nega o mundo em vista de uma verdade transcendente.

Uma importante conclusão que se pode extrair da teoria nietzschiana da vontade de potência que está por trás de todo tipo de conhecimento é expressa na seguinte máxima "Não há conhecimento em si”. Em última instância, essa máxima defende a tese de que não há uma relação entre sujeito e objeto que seja constante, essencial e anterior ao próprio conhecimento. De acordo com Foucault ${ }^{360}$, Nietzsche é contrário à ideia de que existe, de um lado, uma subjetividade a priori capaz de conhecer e, de outro lado, uma objetividade a ser conhecida. Ou seja, para Nietzsche, sujeito e objeto são produzidos pelo conhecimento, antes de lhe servir de fundamento. "Longe da relação sujeito-objeto ser constitutiva do conhecimento, a ilusão primeira e maior do conhecimento, é a existência de um sujeito e de um objeto", conclui Foucault ${ }^{361}$. Por esse motivo, segue Foucault, no centro do conhecimento, Nietzsche se recusa a colocar qualquer coisa como o cogito, que supõe de um lado a consciência pura de um sujeito e de outro um objeto a ser conhecido.

\footnotetext{
${ }^{360}$ Cf. Foucault, Leçons sur la volonté de savoir, p. 202.

${ }^{361}$ Foucault, Leçons sur la volonté de savoir, p. 204.
} 
O conhecimento não parte da consciência pura de um sujeito, mas, como vimos, da atividade violenta dos impulsos que lutam a todo custo a favor da vida, seja por meio da sistematização e organização da realidade, pela sua contemplação, destruição ou negação. E de acordo com o querer da vontade de potência, as coisas se constituem como objeto de um ou outro modo: ora como objetos a serem contemplados, ora como objetos a serem destruídos, ora como objetos a serem utilizados ou conhecidos em sua essência. E se a teoria da vontade de potência explica a atividade violenta e os interesses vitais que estão por trás do conhecer, a ideia da verdade enquanto interpretação explica as diferentes maneiras de se formar os objetos do conhecimento. Por meio da interpretação o homem, que necessariamente tem um olhar perspectivo e interessado do mundo, irá construir os objetos a serem conhecidos. Como? Atribuindo marcas ao caos do mundo, isto é, reificando o mundo por meio dos signos, das palavras. Assim, perguntando-se o que Nietzsche coloca no lugar do cogito, Foucault responde: “o jogo da marca e do querer, da palavra e da vontade de poder, ou ainda, do signo e da interpretação" ${ }^{" 362}$. Vejamos, então, como isso se dá.

A verdade como interpretação em Nietzsche

Todo conhecimento faz violência à realidade ao impor-lhe "a analogia de uma semelhança"363; todo conhecimento é desde o início uma interpretação na medida em que procura dar ao caos uma ordem e um sentido. É por meio dos signos, em especial da palavra, que os homens fazem isso: aproximam o que lhes parece semelhante e lhe submetem ao mesmo nome. Diz Foucault:

O signo é a violência da analogia, é o que domina e desfaz as diferenças. A interpretação é o que coloca e impõe os signos, é o que joga com eles, é o que introduz diferenças radicais (aquelas da palavra e do sentido) sobre as diferenças primeiras do caos. O signo é a interpretação na medida em que ele introduz sobre o caos a mentira das coisas. E a interpretação é a violência feita ao caos pelo jogo coisificante dos signos ${ }^{364}$.

O mundo, ensina Nietzsche, não é constituído de coisas iguais, ou seja, de objetos que pertençam a uma mesma classe. O que existe são diferenças. O nome folha, por exemplo, que indica o conceito de folha, é uma violência feita às diferentes folhas existentes na realidade, no caos da realidade; violência que as aproxima pela "analogia da semelhança" e as submete a um mesmo signo e, portanto, a um conceito. Diz Nietzsche em Sobre verdade e mentira:

\footnotetext{
${ }^{362}$ Foucault, Leçons sur la volonté de savoir, p. 204.

${ }^{363}$ Idem, p. 203.

${ }^{364}$ Idem, p. 204.
} 
Tão certo como uma folha nunca é totalmente igual a uma outra, é certo ainda que o conceito de folha é formado por meio de uma arbitrária abstração dessas diferenças individuais, por um esquecer-se do diferenciável, despertando então a representação, como se na natureza, além das folhas, houvesse algo como que fosse "folha", tal como uma forma primordial $[\ldots]^{365}$.

Ora, na medida em que o conhecimento constrói coisas ou objetos a partir da subsunção das diferenças a um único signo, isto é, na medida em que é interpretação, o conhecimento é uma falsificação da realidade, ele não a apresenta tal como ela é em sua multiplicidade, mas a apresenta sempre a partir de uma perspectiva (perspectiva do olhar que recorta da realidade o que lhe interessa e perspectiva do signo que representa a diversidade por meio de uma única marca). Assim, ao introduzir no caos "o reino abusivo da semelhança" ${ }^{366}$, o conhecimento desfaz a multiplicidade e as diferenças, em benefício de uma marca (signo, palavra) que, no fim das contas, não passa de uma metáfora da realidade e não da própria realidade. As palavras, nesse sentido, diz Nietzsche, não são uma "expressão adequada" da realidade; não passam de "demarcações arbitrárias" e de "preferências unilaterais, ora por esta, ora por aquela propriedade de uma dada coisa!"’367. As palavras, portanto, nunca são designações de "coisas em si"; elas apontam, antes, para "as relações dos homens com as coisas"368. Continua Nietzsche: "Acreditamos saber algo acerca das próprias coisas, quando falamos de árvores, cores, neve e flores, mas, com isso, nada possuímos senão metáforas das coisas, que não correspondem, em absoluto, às essencialidades originais" 369 .

No artigo "Nietzsche, Freud, Marx", de 1964, Foucault defende a tese de que esses três autores mudaram a natureza do signo e a maneira como ele pode ser interpretado ${ }^{370}$. De modo geral, o que fizeram foi ampliar o valor dos signos para além de seu valor de significante. A moeda, a palavra e o sintoma seriam os signos investigados, respectivamente, por Marx, Nietzsche e Freud. De acordo com Foucault, para os três autores, a importância desses signos não deve ser encontrada naquilo que eles significam (seu maior valor não está em serem significantes de um significado: nada de estruturalismo!), mas na interpretação que eles impõem. Ou seja, os signos devem ser vistos desde o início como uma interpretação. "Os signos são já uma interpretação", confirma Foucault ${ }^{371}$.

\footnotetext{
365 Nietzsche, Sobre verdade e metira, pp. 32-33.

${ }^{366}$ Foucault, Leçons sur la volonté de savoir, p. 204.

${ }^{367}$ Nietzsche, Sobre verdade e mentira, p. 31.

368 Ibidem.

369 Idem, p. 33.

${ }^{370}$ Foucault, "Nietzsche, Freud, Marx”, in DE I, p. 595.

${ }^{371}$ Idem, p. 600.
} 
Sendo a palavra o signo privilegiado por Nietzsche (não nos esqueçamos que Nietzsche é antes de tudo um filólogo), Foucault retoma um exemplo do início da Genealogia da moral, a fim de mostrar em que sentido a palavra não indica apenas um significado, mas impõe uma interpretação.

“A palavra 'bom' não é ligada necessariamente a ações 'não egoístas"”372 e tampouco é sinônimo de útil ou conveniente, diz Nietzsche. Para compreender o seu sentido é preciso investigála do ponto de vista etimológico. É o que faz Nietzsche, chegando à seguinte conclusão: as designações para "bom” estão ligadas, em diversas línguas, aos conceitos de nobre e aristocrático. "Bom” é, então, o nome dado aos "espiritualmente nobres", "aristocráticos”, “espiritualmente bemnascidos", "espiritualmente privilegiados"373. Assim, conclui Nietzsche, "é de interesse nada pequeno constatar que, nas palavras e raízes que designam o 'bom', transparece ainda com frequência a nuance cardeal pela qual os nobres se sentiam homens de categoria superior" 374 . Segundo o filósofo, portanto, o sentido do termo grego agathón deveria ser buscado nessa direção.

Por mais que as análises filológicas de Nietzsche não sejam todas corretas, tal como sugere seu tradutor Paulo César de Souza em nota ${ }^{375}$, o importante é compreender a tese nietzschiana de que toda palavra é mais do que um mero signo que aponta para um significado; ela é fruto de uma interpretação, de certa concepção de mundo, de certa maneira de valorizá-lo, hierarquizá-lo e utilizá-lo. No caso, a sugestão de Nietzsche é a de que o termo "bom" esteja ligado à visão de mundo que opõe hierarquicamente nobres e plebeus, ricos e pobres. É por esse motivo, portanto, como insiste Foucault, que o importante para Nietzsche não é compreender o significado das palavras, mas quem as fala, quem propõe as palavras e suas interpretações. Diz Foucault, "não se interpreta o que há no significado, mas o que está por trás; quem colocou a interpretação"376. Afinal, confirma Nietzsche, são os próprios nobres, que se sentiam como homens de categoria superior, que designam a si mesmos como "bons" em oposição aos espíritos inferiores; são eles, portanto, que cunham o termo "bom" para se referirem a sua superioridade 377 . Em As palavras e as coisas, arremata, então, Foucault: "Para Nietzsche, não se tratava de saber o que eram em si mesmos o bem e o mal, mas quem era designado, ou antes, quem falava, quando, para designar a si próprio se dizia

\footnotetext{
372 Nietzsche, Genealogia da moral, I, § 2 e 3, pp. 19-20.

${ }^{373}$ Cf. Nietzsche, Genealogia da moral, I, § 4, p. 21.

${ }^{374}$ Nietzsche, Genealogia da moral, I, § 5, pp. 21-22.

${ }^{375}$ Cf. Nietzsche, Genealogia da moral, nota 3, p. 153.

376 Foucault, "Nietzsche, Marx, Freud", in DE I p. 601.

377 Nietzsche, Genealogia da Moral, I, § 5, pp. 21-22.
} 
agathós, e deilós para designar os outros. Pois é aí, naquele que mantém o discurso e mais profundamente detém a palavra, que a linguagem inteira se reúne" 378 .

Note-se, porém, como já insistimos, que a pergunta por quem fala não deve nos remeter a uma investigação de um sujeito falante soberano. Longe disso. Por mais que Nietzsche, segundo Foucault, dê o nome de psicologia ao domínio do "quem fala"379, a hermenêutica nietzschiana não deve apontar para um antropologismo ou psicologismo. As análises filológicas de Nietzsche servem antes para nos fazer ver que é o domínio da vontade de potência que está por trás da linguagem. Domínio este constituído pela luta existente entre os impulsos inconscientes do homem; luta que o impele ao domínio e superação de si e do mundo, e que é imprescindível para a vida e a conservação. Assim, se as análises dos signos empreendidas por Nietzsche não fazem nenhuma referência a um sujeito constituinte e originário, polo irradiador de sentido e consciente de si mesmo, é justamente porque elas estão articuladas não com a busca de um fundamento com estatuto ontológico definido, como o cogito, mas com a análise de uma multiplicidade de impulsos inconscientes, ou seja, com a análise de um sistema de relações violentas e dominadoras ${ }^{380}$.

Mas se as palavras, em Nietzsche, não passam de metáforas do mundo, metáforas que apontam para o perspectivismo e a interpretação da vontade de potência, o que dizer da verdade? O que dizer da verdade no contexto de um conhecimento que é interpretação e falsificação da realidade? A verdade, em Nietzsche, é uma invenção; é também fruto da interpretação de certo tipo de conhecimento que, com suas motivações próprias, constrói os objetos, suas essências e suas verdades. Foucault se serve mais uma vez de uma passagem de $A$ vontade de poder (§ 291): “A verdade não é [...] uma coisa que existiria e que se trataria de encontrar, de descobrir; mas uma coisa que é preciso criar e que fornece um nome para um certo processo, mais ainda, para uma vontade de fazer violência aos fatos [...]"381. Ou seja: só há verdade quando a vontade de potência toma a forma de uma vontade de verdade. E se é a vontade de potência, com suas forças impulsivas e inconscientes, que está na "raiz e na razão de ser da verdade", se a vontade de verdade é ainda uma vontade de potência, é preciso notar, como faz Foucault, que Nietzsche opera um importante

\footnotetext{
${ }^{378}$ Foucault, As palavras e as coisas, p. 421.

${ }^{379}$ Foucault, "Nietzsche, Marx, Freud", in DE I, p. 601.

${ }^{380}$ Carlos Alberto Ribeiro de Moura nos dá uma explicação esclarecedora e aprofundada acerca da noção de vontade de potência e de como ela não diz respeito a um conceito ontológico. A noção de vontade de potência, diz, não é um conceito ontológico, mas "designa, antes de tudo, o conceito de uma relação [...] é a forma na qual o processo natural realiza-se como um processo de diferenciação, como um vir-a-ser” (Moura, Nietzsche: civilização e cultura, p. 197).
} 
deslocamento no que diz respeito à tradição filosófica. Nietzsche é, pois, aos olhos de Foucault, o filósofo que pensa a relação entre vontade e verdade mediada pela violência.

Para a tradição filosófica, e Foucault fala em Platão e Descartes, se há uma relação entre vontade e verdade é porque a vontade está privada de seus desejos e sua violência, isto é, porque é pura. O querer a verdade, aqui, é o querer da atenção e da sabedoria: o querer do conhecimento teórico e ascético. Querer que exige um sujeito puro, livre de determinações e pronto para apreender a presença do objeto, sem deformação (o conhecimento evidente de Descartes) e um querer que domina o corpo, suspende o desejo e bloqueia os apetites (o conhecimento ascético de Platão). E Foucault continua: a tradição filosófica, e aqui ele fala em Platão, Kant e Heidegger, que pensa a relação entre vontade e verdade por meio de uma vontade pura coloca no coração dessa relação vontade/verdade a liberdade e não a violência, como quer Nietzsche. Para a tradição filosófica, arremata Foucault: "A liberdade é o ser da verdade, e é o dever da vontade" 382 . A verdade é livre em relação à vontade na medida em que não recebe dela nenhuma de suas determinações (ontologia da verdade); por outro lado, a vontade deve ser livre a fim de poder dar acesso à verdade (ética da vontade).

Antípoda da concepção de verdade livre das determinações da vontade, é a verdade tal como Nietzsche a entende. Para o filósofo alemão, a verdade é absolutamente determinada pelos interesses da vontade. Ou seja, a verdade, assim como toda representação, é criada pela vontade. Ao contrário da tradição filosófica, em Nietzsche, não há primeiro a verdade e a representação e depois uma vontade que se direciona a elas. Não. As verdades, assim como todas as representações, são frutos da interpretação da vontade de potência. É por esse motivo, portanto, que mais do que pertencerem ao domínio da epistemologia, a natureza das verdades é moral. Antes de anunciar a essência profunda das coisas, a verdade aponta para o olhar perspectivista dos homens e para seus desejos inconscientes de luta: luta contra o caos da realidade, luta contra o caos do próprio corpo, luta contra os outros homens, enfim, luta pela sobrevivência. Além disso, quer dizer, além de estar situada no campo da moral e estar estritamente vinculada à violência dos impulsos de sobrevivência, a verdade, em Nietzsche, não é verdadeira, mas uma mentira, uma ilusão e um erro. Desse modo, antes de ser mais um filósofo situado no interior da tradição metafísica ocidental, tal como quer Heidegger, Nietzsche é justamente aquele que se opõe a seus principais postulados. É o que podemos depreender das seguintes palavras do próprio Nietzsche, em Genealogia da moral:

De agora em diante, senhores filósofos, guardemo-nos bem contra a antiga, perigosa fábula conceitual que estabelece um "puro sujeito do conhecimento, isento de vontade, alheio à dor e ao tempo", guardemo-nos dos tentáculos de conceitos contraditórios como "razão pura", "espiritualidade

\footnotetext{
${ }^{382}$ Foucault, Leçons sur la volonté de savoir, p. 206.
} 
absoluta", "conhecimento em si"; - tudo isso pede que se imagine um olho que não pode absolutamente ser imaginado, um olho voltado para nenhuma direção, no qual as forças ativas e interpretativas, as que fazem com que ver seja ver-algo, devem estar imobilizadas, ausentes; exige-se do olho, portanto, algo absurdo e sem sentido ${ }^{383}$.

E Foucault confirma a favor de Nietzsche: "Esse modelo de um conhecimento fundamentalmente interessado, produzido como acontecimento do querer e que determina por falsificação o efeito de verdade, está sem dúvida muito distante dos postulados da metafísica clássica" ${ }^{384}$.

No que diz respeito à verdade enquanto mentira, erro e ilusão, muito se teria a dizer sobre cada um desses predicados. Aqui, contudo, nos limitaremos a retomar as sucintas explicações de Foucault sobre o assunto.

Segundo Foucault, para Nietzsche, a verdade tal como quer a tradição filosófica é um erro já que é produzida por um sistema de erros que não apreende a realidade tal como ela é, mas a deforma, a domina, a falseia. Além disso, ao passo que todo conhecimento é uma ilusão (ilusão de ser conhecimento verdadeiro de coisas que existem verdadeiramente), a verdade produzida por esse conhecimento é mais uma ilusão (ilusão de se opor a tudo o que é não-verdadeiro e ilusão de ser o verdadeiro). Por fim, a verdade é também uma mentira, uma vez que ela é outra coisa do que pretende ser. Na medida em que a verdade se anuncia como recompensa do conhecer, ela não é verídica $^{385}$. Ou seja, a verdade que se diz verdade não é verdadeira, mas, antes, uma mentira.

Contudo, mesmo sabendo que a verdade não passa de erro, ilusão e mentira, Nietzsche confere certa utilidade a ela. Seguramente não é qualquer verdade que será útil. Só serão úteis aquelas que de alguma maneira aumentam nossa vontade de potência, ou seja, a verdade trágica e as verdades corporais, e jamais as verdades teóricas e ascéticas que, como vimos, enfraquecem o homem.

Ora, mas não fora justamente Kant, antes mesmo de Nietzsche, que ensinara que as representações ilusórias têm também sua utilidade? A grande importância da "Dialética transcendental" não está precisamente em ter apontado para a utilidade reguladora das ilusões da razão? Além disso, na Antropologia de um ponto de vista pragmático, Kant não teria, como nota Foucault, apontado também para a utilidade vital de certas representações ilusórias? Talvez Foucault tenha razão: toda a filosofia moderna nasce da problemática da ilusão transcendental. E se, por um lado, a ilusão transcendental, como vimos no primeiro capítulo deste trabalho, deu margem

\footnotetext{
${ }^{383}$ Nietzsche, Genealogia da moral, III, § 12, p.109.

${ }^{384}$ Foucault, "Résumé du cours", in Leçons sur la volonté de savoir, p. 220.

385 Cf. Foucault, Leçons sur la volonté de savoir, p. 207.
} 
para o nascimento de uma outra ilusão, a ilusão antropológica das analíticas da finitude, por outro lado, ela pode ter influenciado outros tipos de reflexões, como a de Nietzsche, por exemplo. Mas se isso faz sentido, é preciso ter em mente uma importante diferença: enquanto as analíticas da finitude se esforçarão para encontrar o estatuto ontológico da natureza humana que está constitutivamente inclinada à ilusão, a filosofia de Nietzsche, assim como a de Foucault, na esteira não da Crítica, mas da Antropologia, se interessarão, não pelos fundamentos naturais de nossas ilusões, mas pelos usos que fazemos delas.

A meu ver, a proximidade entre Kant e Nietzsche no que diz respeito ao uso interessado de nossas iluões é indicada por Foucault em seu comentário à Antropologia. Que na "Introdução à Antrpoplogia” seja possível encontrar uma vizinhança entre Kant e Nietzsche, contudo, não é tese nossa. É o próprio Foucault quem sugere tal paralelo. Diz o filósofo:

De que cegueira teríamos nos favorecido para não ver que a articulação autêntica do Philosophieren
[articulaçãa entre a priori, originário e finifute] estava de novo presente, e sob um forma bem mais
restritiva, em um pensamento que por si mesmo talvez não houvesse percebido com precisão aquilo
que conservava de filiação e de fidelidade para com o velho "Chinês de Königsberg"? 386

De acordo com Didier Eribon, Jean Hyppolite, que assumiu o papel de "directeur de recherches" da "petite thèse", confirma o caráter nietzschiano no escrito de Foucault afirmando que se tratava de uma introdução histórica que serviria de esboço para um futuro livro sobre a antropologia, mais inspirado por Nietzsche do que por Kant ${ }^{387}$.

Mas onde afinal estaria a inspiração nietzschiana na tese sobre a Antropologia de um ponto de vista pragmático: na metodologia ou no próprio conteúdo? A nosso ver em ambos. A proposta de ser tanto uma leitura estrutural quanto genética da obra de Kant indica já alguma coisa do método nietzschiano. É certo que Foucault ainda lhe dá o nome de "arqueologia" ou "geologia profunda" 388 e que a tese complementar não deixa de ter paralelos metodológicos com o Gênese e Estrutura da Fenomenologia do espírito de Hegel, de Hyppolite. No que tange a Hyppolite, contudo, os organizadores da edição francesa da tese complementar acreditam que é só no começo e no fim do ensaio que Foucault se preocupa com as categorias de gênese e estrutura ${ }^{389}$. No que concerne ao caráter arqueológico do texto, vimos, pois, que a tese sobre Kant seria só um esboço de um livro futuro sobre a arqueologia da antropologia, ou arqueologia das ciências humanas. E se a tese complementar já nos dá um esboço do método arqueológico, por que não pensar que ela também

\footnotetext{
${ }^{386}$ Foucault, "Inroduction à l'Anthropologie”, p. 68.

${ }^{387}$ Eribon, Michel Foucault, p. 138.

388 Foucault, "Introduction à l'Anthropologie", p. 12.

389 Foucault, "Présentation", in “Introduction à l'Anthropologie”, p. 8.
} 
consiste num esboço do método genealógico? Ora, na medida em que Foucault busca compreender o contexto histórico que está por trás do texto de Kant, não poderíamos dizer que se trata já de uma genealogia que busca compreender a vontade de potência que está por trás do filósofo alemão? Uma genealogia que busca investigar as disputas teóricas que o instiga, assim como os interesses pessoais de Kant em escrever sobre a vida, justamente no momento em que se aproximava da morte?

Mas é possível também que a influência de Nietzsche esteja presente no conteúdo da "Introduction a l'Anthropologie". Assim, não só a maneira como Foucault leu Kant foi nietzschiana, mas são também nietzschianos os temas que Foucault escolhe comentar em Kant. E a meu ver, como já disse, o tema do uso interessado de algumas de nossas representações, principalmente as representações ilusórias, indica a proximidade que nosso autor vê entre os dois filósofos alemães ${ }^{390}$.

Foucault leitor de Kant e Nietzsche: o uso interessado das representações

Vimos já que, de acordo com Foucault, na Antropologia de um ponto de vista pragmático as representações ilusórias parecem ter tanto uma importância reguladora como uma utilidade vital. $\mathrm{Na}$ medida em que certas representações falsas acabam fortalecendo os vínculos sociais e o convívio, podemos dizer que ainda na Antropologia elas funcionam como princípio regulador ao fazer o homem agir de acordo com seu fim. A humanidade, enquanto fim moral e universal dos homens, é visada na Antropologia. Não é à toa, insiste Foucault, que a Antropologia ensina e prescreve: ensina e prescreve o que podemos e o que devemos fazer de nossas representações a fim de efetivarmos nossa destinação moral e alcançarmos a humanidade.

Ora, seguramente o tema de uma humanidade que se deve ter em vista a fim de garantir um progresso moral é estranho tanto a Foucault quanto a Nietzsche. Esses autores até podem conceder que muitos de nós tenhamos uma ideia de humanidade, ideia talvez tão ilusória quanto em Kant, mas que ela seja uma ideia racional pertencente a todos os homens e uma ideia que tende a se

\footnotetext{
$390 \mathrm{Na}$ ocasião da qualificação do presente trabalho, Márcio Suzuki sugeriu que o livro Die Philosophie des Als Ob (A filosofia do como se), de 1911, do neo-kantiano Hans Vaihinger, poderia ajudar para traçar paralelos entre Kant e Nietzsche. É preciso agradecer a preciosa indicação, pois a tese de Vaihinger encorajou-me a encontrar em Foucault a ideia de que os dois filósofos alemães se aproximam justamente no que diz respeito à ilusão, ao como se, à ficção.
} 
realizar de fato concretamente, mesmo que progressivamente, talvez seria supor um universalismo e uma teleologia que ambos parecem querer evitar ${ }^{391}$.

No entanto, apesar do caráter essencialista e universalista presente na figura do cidadão do mundo, pois é a figura do universal concreto da moral, o cidadão do mundo não deixa de ser interessante para pensarmos a relação entre Kant, Nietzsche e Foucault. Afinal, se Nietzsche e Foucault recusam o universal da humanidade, isso não significa que eles não deem importância para os vínculos sociais e para o convívio entre os homens. Muito pelo contrário. Eles querem mesmo entender como isso acontece e, assim como Kant, também atribuem papel importante às representações no que diz respeito à sociabilidade.

Já vimos, por exemplo, em Nietzsche, que certas representações falsas são úteis na medida em que possibilitam a comunicação e, portanto, o convívio social. A linguagem em geral, que é sempre metafórica e uma falsificação da realidade, é exemplo disso. É verdade que as relações interpessoais, em Nietzsche, estão sempre submetidas ao princípio individual de vontade de potência. O convívio social parece ser interessante e útil somente na medida em que aumenta a vontade de potência, na medida em que disperta a luta pela vida e que contribui para a autossuperação e o autodomínio. Uma sociabilidade igualitária, harmoniosa e pacificadora, tal como parece ser a desejada por Kant, não passaria, aos olhos de Nietzsche, de uma esperança típica dos espíritos fracos que querem encontrar na vida de rebanho o apaziguamento das relações violentas e combativas entre os homens. Contudo, apesar das diferentes justificativas que um e outro filósofo dão à utilidade das ilusões para o convívio social, o que nos interessa aqui é notar que, tanto para Kant quanto para Nietzsche, a relação entre os homens é necessariamente mediada por representações falsas.

Pensando principalmente na antropologia pragmática de Kant e nos textos em que Nietzsche fala sobre a necessidade de aparência, podemos dizer que tanto para um quanto para outro é necessário e, portanto, inevitável, que o homem produza ilusões ${ }^{392}$. Mas não só. Para ambos os

\footnotetext{
391 Como exemplo do caráter teleológico da Antropologia poderíamos citar a seguinte passagem: “Os mais fortes impulsos da natureza, que substituem a razão invisível (do regente do mundo), a qual cuida universalmente do gênero humano mediante uma natureza superior, o bem físico do mundo, sem que a razão humana possa atuar nisso, são amor à vida e amor sexual: o primeiro para manter o indivíduo, o segundo para manter a espécie, porque por meio da união dos sexos a vida de nossa espécie dotada de razão se conserva progredindo no todo, apesar de trabalhar deliberadamente em sua própria destruição (por meio de guerras), destruição, porém, que não impede as criaturas racionais em cultura sempre crescente de representar inequivocamente em projeção ao gênero humano um estado de felicidade nos séculos vindouros, do qual não mais se retrocederá" (Kant, Antropologia..., § 87, p. 174).

392 Bem próximo do que acabamos de ver em Kant sobre a importância da fantasia para a vitalidade da mente, poderíamos lembrar uma passagem de $O$ nascimento da tragédia, onde Nietzsche também ressalta o caráter necessário e vital das fantasias no sonho (Cf. Nietzsche, O nascimento da tragédia, §1, pp. 28-29).
} 
filósofos as ilusões não são somente necessárias e inevitáveis, mas também úteis e interessadas: elas servem para mediar a relação entre os homens, assim como para aumentar a força vital de cada um.

Mas o que, afinal, tudo isso tem a ver com Foucault?

Ora, também em Foucault encontramos o tema da ilusão necessária e útil, o tema do uso que fazemos de nossas representações, mesmo daquelas que são falsas e não verdadeiras. Vimos já que o método arqueológico se interessava pelos usos que fazemos dos signos linguísticos; não pelos usos que fazemos da linguagem a fim de construir proposições verdadeiras (esse seria um uso lógico da língua), mas o uso que damos a ela no intuito de construir discursos e enunciados aceitos e valorizados como verdadeiros, mas que não necessariamente são verdadeiros (esse seria propriamente o sentido do uso pragmático da língua que procurei ressaltar em Foucault). Vimos, portanto, que em suas análises sobre o discurso e o saber, mais do que uma investigação acerca das condições necessárias para a produção de conhecimentos verdadeiros, estava em questão pensar quais teriam sido as condições necessárias (as práticas concretas que constroem sujeitos, objetos, conceitos e teorias) que possibilitaram que certo uso da linguagem produzisse um conhecimento aceito como verdadeiro. Com os termos de Foucault, tratava-se mais de uma pesquisa sobre as condições singulares de existência de certos usos da linguagem que produziram um discurso verdadeiro, do que das condições universais de possibilidade do conhecimento verdadeiro. E se, por um lado, a centralidade do tema do uso mantém Foucault próximo tanto de Nietzsche quanto de Kant, e de suas reflexões acerca dos usos que fazemos de nossas representações e conhecimentos, por outro lado, nosso autor manteve-se mais fiel ao autor da Genealogia da moral quando se tratava de explicar as condições desses usos.

De certa maneira, podemos dizer que a arqueologia já é, de certo modo, uma genealogia, na medida em que procura na exterioridade do conhecimento a justificativa para o seu uso. Nesse sentido, toda a descrição foucaultiana das práticas discursivas e não discursivas que determinam a formação de um discurso poderia ser compreendida como uma tentativa de encontrar fora do campo do próprio conhecimento suas condições de existência. Apesar desse caráter genealógico do método arqueológico, Foucault só usa o termo "genealogia" para qualificar as pesquisas focadas nas relações de poder que permeiam as práticas exteriores ao conhecimento. A nosso ver, portanto, não é qualquer investigação sobre a exterioridade do conhecimento que pode ser dita genealógica, mas o são somente aquelas que se dedicam à compreensão dos interesses que estão por trás do que é dito como verdade, que se dedicam, portanto, à compreensão do quem fala. Assim, se a arqueologia, como vimos, consistia numa investigação acerca das condições de existência dos usos que fazemos dos signos linguísticos, mostrando como eles se dão na prática, a genealogia, como veremos, 
consistirá num estudo sobre os interesses e as estratégias que possibilitam que a verdade seja valorizada de uma ou outra maneira.

No próximo capítulo retomaremos algumas considerações de Foucault acerca da relação entre sujeito e verdade, relação que, segundo o filósofo, sempre esteve no centro de suas pesquisas. Em primeiro lugar, trata-se de mostrar que, para Foucault, nossa relação com a verdade, seja a verdade das coisas, dos outros ou de nós mesmos, é sempre histórica: ela varia de um momento a outro, de um lugar a outro. Ou seja, a relação entre sujeito e verdade não é, tal como propõe Aristóteles, uma relação evidente e imediata. Não conhecemos as coisas, os outros e nós mesmos sempre do mesmo modo: não só os objetos mudam, mas também o sujeito que conhece muda. Isso significa, então, em segundo lugar, que Foucault não acredita, na esteira de Nietzsche, na perenidade do sujeito e do objeto do conhecimento. Para ele, assim como para o filósofo alemão, não existe "conhecimento em si"; não existe uma relação imediata e intrínseca entre o sujeito que conhece e a verdade do objeto conhecido. Para Foucault, assim como para o autor da Genealogia da moral, a relação entre o sujeito e a verdade é sempre uma relação de exterioridade e sempre mediada. Mediada pelo quê? Em Nietzsche, como vimos, ela é mediada pela vontade de potência. Em Foucault, como veremos, a relação entre sujeito e verdade também passará pela instância do poder, mas pelo poder político; um poder que não diz respeito a um impulso individual de conservação, mas que se manifesta e efetua por meio de diferentes práticas sociais, como as práticas econômicas, religiosas e jurídicas. 


\section{CAPÍTULO 5. QUEM FALA? A VONTADE DE SABER EM FOUCAULT}

A relação entre verdade e sujeito, em Foucault, poderia ser abordada de diversas maneiras e por diferentes caminhos, dadas a generalidade e a centralidade do tema no interior de sua obra. Optaremos aqui por retomar a questão tal como ela é formulada pelo filósofo no primeiro curso do Collège de France, Leçon sur la volonté de savoir, e em algumas conferências que dão continuidade aos assuntos tratados no curso. Essa opção justifica-se ao menos por duas razões. Em primeiro lugar, acreditamos valer mais aprofundarmos nossos comentários de um texto ao qual já nos referimos antes do que introduzirmos mais um curso ou mais um livro de maneira superficial e parcial. Em segundo lugar, pensamos que o primeiro curso do Collège de France, talvez justamente por ser o primeiro, é paradigmático no que diz respeito ao programa filosófico de Foucault; ele nos mostra com clareza as linhas de força das pesquisas foucaultianas, suas intenções e seus métodos, principalmente no que diz respeito à relação entre sujeito e verdade, que é o tema que aqui nos interessa.

Como já vimos, as quatro primeiras aulas do curso são dedicadas à contraposição entre Aristóteles e Nietzsche. A oposição entre duas maneiras distintas de conceber a vontade de saber, contudo, serve somente como introdução metodológica ao curso. A nosso ver, ela serve para Foucault deixar claro que, no interior da história da filosofia, há ao menos dois modos diferentes de de pensar a relação entre sujeito e verdade: um que é predominante até nossos dias, e outro que pode servir como alternativa ao poder hegemônico do primeiro. E se, por um lado, Foucault usa Nietzsche como alternativa possível a um tipo de pensamento dominante, por outro lado, ele o usa também a fím de compreender o aparecimento desse próprio modo de pensar. É, portanto, a partir do modelo nietzschiano da vontade de saber que nosso autor procurará empreender, a partir do curso de 1970/71 (do meu ponto de vista, esse é o projeto geral que anima suas pesquisas até seus últimos escritos), certa história da verdade ou certa história da relação entre sujeito e verdade (entre certa concepção de sujeito de conhecimento e certa concepção de verdade), que começa na antiguidade grega e que chega até os nossos dias. História essa que começaria ali na antiguidade grega, mais especificamente em Aristóteles, quando este defende a tese de que todos os homens por natureza desejam conhecer.

Numa conferência de 1973, é então da seguinte maneira que Foucault justifica o uso que faz de Nietzsche:

O Ocidente vai ser dominado pelo grande mito de que a verdade nunca pertence ao poder político, de que o poder político é cego, de que o verdadeiro saber é o que se possui quando se está em contato com os deuses ou quando recordamos das coisas, quando olhamos o grande sol eterno ou abrimos os olhos para o que se passou. [...] Esse grande mito precisa ser liquidado. Foi esse mito que Nietzsche 
começou a demolir ao mostrar, em numerosos textos já citados, que por trás de todo saber, de todo conhecimento, o que está em jogo é uma luta de $\operatorname{poder}^{393}$.

Vejamos, então, de que maneira o modelo nietzschiano da vontade de saber está presente nessa história foucaultiana sobre a relação entre sujeito e verdade tal como ela aparece no curso Leçon sur la volonté de savoir e em algumas conferências subsequentes. Vejamos como nosso autor se utiliza das teses nietzschianas a fim de fazer a sua própria genealogia e a sua maneira de fazer filosofia.

A exterioridade do conhecimento: a história da nossa vontade de verdade entre Nietzsche, Dumézil e a psicologia histórica

O período analisado por Foucault no curso de 1970/1 refere-se ao período compreendido entre os séculos VII e V a.C. Período que parece funcionar como passagem entre a Grécia arcaica de Homero e a Grécia clássica da filosofia; período marcado por figuras híbridas que mantêm contato tanto com o modo de pensar arcaico e mítico quanto com o modo de pensar clássico e racional, como é o caso de Hesíodo; marcado por importantes transformações, principalmente no que diz respeito às concepções de justiça, medida e ordem, e que afetam as práticas sociais, políticas, econômicas e religiosas dos homens.

Diferentemente de Nietzsche que se vale da filologia como instrumento central da genealogia, Foucault irá se apoiar na história. São os historiadores helenistas que irão fornecer a Foucault o material necessário para compreender o nascimento de certa concepção de verdade.

No que diz respeito às fontes históricas de Foucault, elas são inúmeras. Graças às notas da edição do curso e ao comentário sobre a situação do curso, vemos que os autores mais citados são: Gustave Glotz (1862-1935), Louis Gernet (1882-1962), Edouard Will (1920-1997) e Louis

\footnotetext{
${ }^{393}$ Foucault, $A$ verdade e as formas jurídicas, p. 51. Cf. ainda Foucault, Leçon sur la volonté de savoir, p. 220: “Teria sido possível, e talvez mais honesto, citar apenas um nome, o de Nietzsche, pois o que digo aqui só tem sentido se relacionado à obra de Nietzsche que me parece ser, entre os modelos de que podemos lançar mão para as pesquisas que proponho, o melhor, o mais eficaz e o mais atual. Em Nietzsche, parece-me, encontramos efetivamente um tipo de discurso em que se faz a análise histórica da própria formação do sujeito, a análise histórica do nascimento de um certo tipo de saber, sem nunca admitir a preexistência de um sujeito de conhecimento".
} 
Moulinier ${ }^{394}$. Além desses autores, também Marcel Detienne (1935-), Jean-Pierre Vernant (1914-2007) e Georges Dumézil (1898-1986) tiveram grande influência para as pesquisas de Foucault. O legado principalmente destes três últimos autores para a obra de Foucault deve ser levado em consideração. Não nos cabe agora fazer um tal estudo. Limitemo-nos a dar algumas indicações que nos ajudam a compreender melhor a empreitada foucaultiana.

Apesar de ser citado somente uma vez, no início da aula de 3 de fevereiro, Dumézil parece ser central para o tipo de trabalho realizado por Foucault. Em diversas ocasiões Foucault sugere tal centralidade e, em geral, ela se deve ao modelo de investigação comparativa realizada por Dumézil e reproduzido por Foucault. $\mathrm{Na}$ aula inaugural do Collège de France, por exemplo, ao reconhecer sua dívida com o autor de Mito e Epopeia, Foucault afirma:

Creio que devo muito a M. Dumézil, pois foi ele que me incentivou ao trabalho em uma idade em que eu ainda acreditava que escrever é um prazer. Mas devo muito, também, a sua obra; que me perdoe se afastei de seu sentido ou desviei de seu rigor esses textos que são seus e que nos dominam hoje; foi ele que me ensinou a analisar a economia interna de um discurso de modo totalmente diferente dos métodos de exegese tradicional ou do formalismo linguístico; foi ele que me ensinou a detectar, de um discurso ao outro, pelo jogo das comparações, o sistema de correlações funcionais; foi ele que me ensinou como descrever as transformações de um discurso e as relações com a instituição ${ }^{395}$.

No curso de 70/71, Foucault retoma a importância de Dumézil no que diz respeito à correlação entre aquilo que é da ordem do discurso e o que é da ordem das instituições. Mais especificamente, retoma a correlação entre produção da verdade e práticas judiciárias, e nesta

\footnotetext{
394 A seguir indico os textos mais citados. De Gustave Glotz: L'Ordalie dans la Grèce primitive. Paris, 1904; Études sociales et juridiques sur l'Antiquité grecque. Paris: Hachette, 1906. De Louis Gernet: Recherches sur le développement de la pensée juridique et morale en Grèce. Paris: E. Leroux, 1917; "Sur la notion de jugement en droit grec", in Archives d'histoire du droit oriental, I, 1937; "Introduction a l'étude du droit grec ancien", in Archives d'histoire du droit oriental, II, 1938; "Le temps dans les formes archaïques du droit", in Journal de psychologie normale et pathologique, LIII (3), 1956; Droit et Société dans la Grèce ancienne. Paris, Sirey, 1955; "Droit et pré-droit en Gréce ancienne" (1951), in Anthropologie et la grèce antique. Paris: Maspero,1968. De Edouard Will: "Réflexions et hypothèses sur les origines du monnayage", in Revue numismatique, 5a série, 17, 1955; Korinthiaka. Recherches sur l'histoire et la civilisation de Corinthe des origines aux guerres médiques. Paris: De Boccard, 1955; "La Grèce archaique", in Actes de la Deuxième Conférence internationale d'histoire économique. Paris: Mouton, 1965; Le monde grec et l'Orient. Paris: PUF, 1972. De Louis Moulinier: "Le Pur et l'Impur dans la pensée et la sensibilité des Grecs jusqu'à la fin du IV ème siècle avant J.-C.”. Paris, Sorbonne, 1950 (tese); Orphée et l'Orphusme à l'époque classique. Paris: Les Belles Lettres, 1955. De Marcel Detienne: Crise agraire et attitude religieuse chez Hésiode. Bruxelas: Latomus, 1963; Les Maîtres de vérité dans la Grèce archaique. Paris: Maspero, 1967. De Jean-Pierre Vernant: "Travail et nature dans la Grèce ancienne", in Journal de psychologie normale et pathologique, LII (1), 1955.

395 Foucault, A ordem do discurso, p. 71. Cf. ainda Foucault, "Sur les façons d'écrire l'histoire", in DE I, pp. 618-9: "Quando Dumézil demonstra que a religião romana está numa relação de isomorfismo com as lendas escandinávias ou celtas ou determinado rito iraniano, ele não quer dizer que a religião romana não tem seu lugar no interior da história romana, que a história de Roma não existe, mas que só podemos descrever a história da religião romana, suas relações com as instituições, as classes sociais, as condições econômicas, tendo em vista sua morfologia interna. Do mesmo modo, demonstrar que os discursos científicos de uma época vêm de um modelo teórico comum não quer dizer que eles escapam à história e flutuam no ar como desencarnados e solitários, mas que não podemos fazer sua história, a análise de seu funcionamenro, do papel desse saber, das condições que são feitas a ele, da maneira como ele se enraíza na sociedade, sem levar em consideração a força e a consistência desses isomorfismos". Cf. ainda Foucault, "Revenir à l'histoire", in DE I, pp. 1142-3: "A análise de Dumézil [...] é uma análise não de uma semelhança, mas de uma diferença e de um jogo de diferenças. Além disso, a análise de Dumèzil não se contenta em fazer um quadro das diferenças, a análise de Dumézil estabelece um sistema de diferenças, com sua hierarquia e suas subordinações. [...] Temos não somente um quadro das diferenças, mas o encadeamento das diferenças umas com as outras. Enfim, a análise estrutural de Dumézil consiste em mostrar quais são as condições de tal transformação".
} 
correlação o que se percebe é a imbricação entre verdade e poder. Foucault, então, cita Dumézil em Servius et la Fortune - Essai sur la fonction sociale de louange et de blâme et sur les éléments indoeuropéens du cens romain (1943):

Por mais longe que remontemos nos comportamentos de nossa espécie, a "palavra verdadeira" é uma força à qual poucas forças resistem [...] a Verdade muito cedo apareceu aos homens como uma das armas verbais mais eficazes, um dos germes de poder mais profícuos, um dos mais sólidos fundamentos para suas instituições ${ }^{396}$.

Em 1973, numa das conferências realizadas no Rio de Janeiro que foram reunidas com o título $A$ verdade e as formas jurídicas, Foucault volta a falar de Dumézil como aquele que mostrou por meio de seus estudos comparativos de mitologia aquilo que Nietzsche já havia mostrado: a inseparabilidade entre saber e poder. O filólogo francês, segundo Foucault, ensinara que nas sociedades indo-europeias do leste mediterrâneo, a dos impérios assírios, no início do primeiro milênio antes de Cristo, "o poder político era sempre detentor de um certo tipo de saber"397. A classe que detinha o poder, o rei e os que o acompanhavam, detinham também certo saber que não podia ser comunicado aos outros grupos socias. Essa espécie de saber misterioso e sigiloso dava ao poder político um caráter mágico, religioso e sacro, o que lhe garantia a preservação.

Foucault esclarece, contudo, que, na França, não foi só Dumézil que esteve atento à sobreposição entre o poder político e o dizer a verdade, entre a correlação existente entre certas práticas sociais e certas práticas discursivas. Há, segundo Foucault, toda uma tradição que fez análise do discurso a partir, principalmente, das práticas judiciárias. É o caso dos autores já citados acima como Glotz, Gernet e Vernant ${ }^{398}$.

As análises históricas dos helenistas que tratam do direito na Grécia arcaica e clássica servem a Foucault justamente para retraçar esse paralelo entre a verdade e as práticas jurídicas. Mais precisamente servem para demonstrar que o nascimento de certa concepção de verdade, a de

\footnotetext{
396 Dumézil apud Foucault, Leçon sur la volonté de savoir, p. 82. Sobre a relação entre as práticas discursivas e outras práticas socias, em Dumèzil, cf. ainda Foucault, $A$ verdade e as formas jurídicas, pp. 144-5: "Dumézil dizia que quando fazia comparações, podia tomar, por exemplo, um mito sânscrito, uma lenda sânscrita, e depois compará-la. Com o quê? Não forçosamente com outro mito mas, por exemplo, com um ritual assírio ou ainda com uma prática judiciária romana. Para ele não há então privilégio absoluto dado ao mito verbal, ao mito enquanto produção verbal, mas admite que as mesmas relações possam intervir tanto num discurso, como num ritual religioso ou numa prática social. E acho que Dumézil, longe de identificar ou de projetar todas as estruturas sociais, as práticas sociais, os ritos, num universo do discurso, recoloca, no fundo, a prática do discurso no interior das práticas sociais. [...] dada a homogeneização feita entre o discurso e a prática social, ele trata o discurso como sendo uma prática que tem sua eficácia, seus resultados, que produz alguma coisa na sociedade, destinado a ter um efeito, obedecendo, consequentemente, a uma estratégia".

${ }^{397}$ Foucault, $A$ verdade e as formas jurídicas, p. 49.

398 Cf. Foucault, $A$ verdade e as formas jurídicas, p. 145. Não falaremos aqui de Jean-Pierre Vernant, mas de Marcel Detienne que, junto com Vernant, na esteira de Ignace Meyerson, procurava realizar uma história do interior do homem grego, de sua organização mental e das mudanças que afetaram o quadro de suas atividades e funções mentais. Cf. Vernant, Mythe et pensée chez les Grecs, p. 5. De acordo com Defert, Foucault frequentou os cursos de Meyerson durante sua formação em psicologia, e provavelmente o livro Les fonctions psychologiques et les oeuvres influenciou Foucault (Cf. Defert, op. cit., p. 259, n. 8).
} 
Aristóteles e a da filosofia em geral, deve ser compreendida em correlação com as práticas do campo do Direito. Assim, se, por um lado, Nietzsche serve como modelo teórico para uma pesquisa que procura mostrar que por trás de todo saber, conhecimento e verdade, há uma luta de poder, por outro lado, as análises dos historiadores e dos filólogos da antiguidade fornecem o conteúdo empírico necessário para compreender o que está por trás do nascimento do saber filosófico do qual Aristóteles seria uma das figuras centrais 399 .

Mas, afinal, por que as práticas jurídicas são tão importantes para uma história da verdade? Nosso autor responde: dentre as práticas sociais, as práticas jurídicas são as mais importantes para a configuração de novas formas de subjetividade e de novas relações entre o sujeito e a verdade. Diz Foucault em uma das conferências do Rio de Janeiro, em 1973:

As práticas judiciárias - a maneira pela qual, entre os homens, se arbitram os danos e as responsabilidades, o modo pelo qual, na história do Ocidente, se concebeu e se definiu a maneira como os homens podiam ser julgados em função dos erros que haviam cometido, a maneira como se impôs a determinados indivíduos a reparação de algumas de suas ações e a punição de outras, todas essas regras ou, se quiserem, todas essas práticas regulares, é claro, mas também modificadas sem cessar através da história - me parecem uma das formas pelas quais nossa sociedade definiu tipos de subjetividade, formas de saber e, por conseguinte, relações entre o homem e a verdade que merecem ser estudadas ${ }^{400}$.

Não é o caso de retomarmos em profundidade todas as análises das concepções de justiça e das práticas judiciárias apresentadas por Foucault no curso Leçons sur la volonté de savoir. Em primeiro lugar, porque as teses defendidas por nosso autor não são originais; como vimos, ele as toma de empréstimo dos especialistas da antiguidade. Além disso, mais do que discutir a validade desses elementos históricos e de compreendê-los em sua profundidade e complexidade, nos interessa aqui entender a metodologia foucaultiana; entender como ele empreende, tal como Nietzsche, uma busca pelo que é exterior ao saber, ao conhecimento e à verdade; ou seja, entender como ele usa Nietzsche para explicar que o nascimento de certa concepção de verdade, que se pretende pura e independente de qualquer desejo, interesse, poder e violência, depende ela mesma de certas relações de poder, de certos interesses políticos e de diversas práticas que põem em jogo

\footnotetext{
399 É tendo isso em vista que podemos compreender o projeto do curso: "Foi ele [o modelo nietzschiano] que, usado livremente, foi colocado em marcha no curso desse ano a propósito de uma série de exemplos. Essa série de exemplos foi tirada da história e das instituições arcaicas gregas. Eles vêm todos do domínio da justiça. Trata-se de seguir uma evolução que se estendeu do século VII a.C. ao século V a.C. Essa transformação concerne à administração da justiça, à concepção do justo e às relações sociais ao crime. [...] A distribuição da justiça foi durante todo o período considerado, motivo de lutas políticas importantes. Elas deram lugar, no fim das contas, a uma forma de justiça ligada a um saber onde a verdade foi colocada como visível, constatável, mensurável, obediente a leis semelhantes àquelas que regem a ordem do mundo e cuja descoberta detém, por seu turno, um valor purificador. Esse tipo de afirmação da verdade deveria ser determinante na história do saber ocidental" (Foucault, Leçon sur la volonté de savoir, p. 220).

400 Foucault, $A$ verdade e as formas jurídicas, p.11. No curso Leçons sur la volonté de savoir Foucault justifica da seguinte maneira a centralidade das práticas jurídicas no que tange à relação entre sujeito e verdade: "A afirmação da verdade esteve presente no discurso jurídico desde a origem [...]. Desde o início certos enunciados são institucionalizados como devendo ser palavras de verdade, palavras com relação à verdade, palavras que põem em jogo a verdade" (Foucault, Leçon sur la volonté de savoir, p. 81).
} 
estratégias específicas. Afinal, confirma Foucault, a ideia de um sujeito puro que se relaciona de maneira desinteressada com a verdade é ela mesma uma ideia historicamente construída: esse sujeito supostamente neutro é, ele próprio, uma produção histórica e tem ele mesmo relações com o poder $^{401}$. Foucault propõe, então, fazer a genealogia da concepção desse suposto sujeito neutro percorrendo as práticas judicárias do período. Justifica o filósofo: "foi preciso toda uma rede de instituições, de práticas, para chegar ao que constitui essa espécie de ponto ideal, de lugar, a partir do qual os homens deveriam pousar sobre o mundo um olhar de pura observação. No conjunto, parece-me que a constituição histórica dessa forma de objetividade poderia ser encontrada nas práticas judiciárias" ${ }^{\prime 402}$.

Tentemos, então, retomar de maneira esquemática os argumentos centrais de Foucault no que tange à relação entre a verdade e as formas jurídicas a fim de compreendermos como o filósofo justifica historicamente o aparecimento do sujeito puro e universal da filosofia, mais especificamente, do sujeito de conhecimento tal como encontramos em Aristóteles.

\section{A Grécia clássica e a nova concepção de justiça: a verdade como constatação}

De acordo com Detienne, em Les Maîtres de Vérité dans la Grèce archaïque, de 1967, tese aceita e repetida por Foucault, o primeiro sinal do pensamento racional e filosófico encontra-se em Hesíodo. Entre os polos “pensamento mítico" e "pensamento racional”, Hesíodo parece configurar uma passagem. Em Os trabalhos e os dias, o mundo começará a aparecer de maneira ordenada não tanto em função das vontades dos deuses, que seguramente é ainda muito presente nos textos de Hesíodo, o mundo como physis, mas em função de um princípio imanente ao próprio mundo: a justiça (diké). A partir de então a verdade do mundo, o mundo agora como kosmos, poderá ser dita e apreendida por um discurso racional e não dependerá tanto de rituais míticos-religiosos para ser proferida e aceita. Aqui, então, surge uma nova figura da verdade que marcará o nascimento da metafísica ocidental e que é correlata a um novo ordenamento jurídico do mundo.

De maneira geral e bem esquemática, podemos dizer que, de acordo com os historiadores da antiguidade citados por Foucault, entre Platão e Homero a grande transformação jurídica que ocorre pode ser percebida através das práticas de justiça. Na Grécia arcaica, e os exemplos aqui são tirados

\footnotetext{
${ }^{401} \mathrm{Em}$ A ordem do discurso, sobre a pretensa neutralidade desse sujeito, Foucault comenta: “O discurso verdadeiro, que a necessidade de sua forma liberta do desejo e libera do poder, não pode reconhecer a vontade de verdade que o atravessa; e a vontade de verdade, essa que se impõe a nós há bastante tempo, é tal que a verdade que ela quer não pode deixar de mascará-la" (p. 20).

402 Foucault, A verdade e as formas jurídicas, p. 138.
} 
das epopeias homéricas e em certa medida dos textos de Hesíodo, procura-se resolver um litígio ou por meio de uma prova ou de um juramento de caráter mágico religioso. Mas em nenhum dos casos trata-se de saber quem tem razão, de fato ou de direito. Quem vence não é necessariamente aquele que, na contenda, falou a verdade, mas aquele que detém mais poder, mais força, habilidade e coragem para levar a cabo a prova ou o juramento. Para o pensamento grego clássico, cujo esboço encontra-se em Hesíodo, principalmente em Os trabalhos e os dias, mas também em Sófocles, no Édipo rei, a justiça não será mais assunto exclusivo dos deuses; ela passará a ser decidida e administrada também pelos homens, por meio de procedimentos bem precisos. O mais importante deles é o inquérito, que põe a percepção como critério central da justiça: para se estabelecer o que é justo será preciso ver ou ouvir a verdade dos fatos, isto é, a verdade precisará ser constatada ${ }^{403}$.

$\mathrm{Na}$ Grécia arcaica, uma vez que a justiça depende dos deuses e não dos homens, num julgamento não importa averiguar se aquele que diz dizer a verdade a diz realmente; interessa, antes, que no plano do conflito entre os homens, eles digam a verdade seguindo os rituais que convém e que assumam os riscos inerentes à disputa. Neste contexto, diz Foucault, os juízes "não devem estabelecer a verdade dos fatos, mas dizer o que é preciso fazer"404. E o que é preciso fazer para se resolver, no plano dos homens, um litígio? Pode-se, por exemplo, fazer um juramento, e aquele que diz dizer a verdade sabe que corre o risco de ser futuramente amaldiçoado caso o que diga não seja realmente a verdade, mas pode-se também defender a verdade do que se diz colocando-se à prova por meio de um desafio corporal que exige coragem e força para ser levado a cabo, como um duelo ou um suplício. Com isso, conclui Foucault: "a palavra verdadeira não revela aquilo que aconteceu; visando os fatos, ela designa aquele que assumiu o risco e exclui aquele que recusa o risco" ${ }^{405}$. Para o pensamento arcaico, portanto, a importância de dizer a verdade não está tanto na verdade daquilo que se diz, mas no como se diz a verdade. Mais do que o valor de verdade daquilo que se diz, o valor da verdade é medido pela coragem de se expor a uma maldição e pela coragem e força em sustentar uma prova física. Nesse sentido, arremata Foucault, a verdade é da

\footnotetext{
${ }^{403} \mathrm{Na}$ seguinte passagem, Foucault resume a diferença entre a Grécia arcaica e a Grécia clássica no que diz respeito à relação entre discurso judiciário e verdade: "No sistema que conhecemos hoje, naquele que se instaura já na época grega clássica, a palavra verdadeira é antes de tudo aquela do testemunho: ela tem a forma da constatação; ela se apoia sobre aquilo que se passou e sua função é de revelá-lo. Ela tem por modelo, ou melhor, por equivalente não verbal a percepção: manifestar as coisas como se estivéssemos lá, como se as víssemos. A palavra da testemunha é substituto da presença. No sistema que evocamos para o período homérico, o equivalente não verbal da palavra verdadeira é a ordália, é a prova física: se expor ou expor alguém a um perigo indefinido. Fazer o juramento de verdade ou se oferecer ao perigo dos golpes, dos raios, do mar, das bestas selvagens - isto tem a mesma forma e a mesma virtude operatória. $\mathrm{Na}$ prática judiciária arcaica, a palavra de verdade não está ligada à luz e ao olhar das coisas; ela está ligada à obscuridade do acontecimento futuro e incerto" (Foucault, Leçon sur la volonté de savoir, pp. 82-3).
}

${ }^{404}$ Idem, p. 77.

${ }^{405}$ Idem, p. 82. 
mesma natureza que a luta ${ }^{406}$; o dizer a verdade não aponta tanto para uma justiça verdadeira, mas se configura, antes, como manifestação de um poder e de uma força $\mathrm{a}^{407}$.

Na Grécia clássica, por outro lado, a importância do dizer a verdade não estará mais em como dizê-la, mas no que se diz; não estará mais no ritual e no modo de dizer, mas no conteúdo do que é dito. A partir de Hesíodo aparece um tipo de ação jurídica diferente daquela baseada no juramento ou na prova física ${ }^{408}$ e que vai, pouco a pouco, tomando a cena jurídica grega: o julgamento que deve estabelecer, a um só tempo, a verdade dos fatos e a justiça da sentença; que deve descobrir o que realmente aconteceu, constatar a verdade daquilo que se diz e, com isso, procurar fazer valer a ordem justa entre os homens.

Segundo Foucault, e aqui nosso autor parece seguir à risca as teses de Detienne e Vernant, o aparecimento de um novo tipo de prática jurídica é correlato a um novo modo de pensar a medida e a ordem das coisas do mundo. Essa nova maneira de pensar o mundo pode ser resumida por meio de um termo: diké. Apesar desse termo aparecer em Homero, é somente em Hesíodo que ele recebe sua real importância. De acordo com Foucault, as poucas recorrências do termo na Ilíada e na Odisseia o ligam sempre à ideia de procedimento legítimo. Nesse sentido, afirma o filósofo: “A diké não é o que rege a ação judiciária, mas o seu desenrolar" ${ }^{409}$. De um procedimento que está de acordo com os costumes, com as leis e com as regras é dito diké. Em Hesíodo, diferentemente, o termo não indica a conformidade de uma ação com as leis dos costumes, mas aponta para um ordenamento legítimo ou justo do próprio mundo dos homens: como deve se dar a partilha da terra, quais são os valores das mercadorias trocadas, quais devem ser os prazos das dívidas, as épocas certas para fazer a semeadura e a colheita. Ou seja, existe um princípio justo, e verdadeiro, que ordena o mundo das relações entre os homens. Justo não é somente as ações humanas que se desenrolam da maneira que convém e a decisão de Zeus; existe uma verdade do mundo que é justa e que deve, portanto, ser conhecida. Confirma Foucault: “A justiça não se ordena mais conforme a uma verdade afirmada ou arriscada; ela está ligada a uma verdade que se sabe. Ser justo não é

\footnotetext{
${ }^{406}$ Cf. Foucault, Leçon sur la volonté de savoir, p. 73.

$407 \mathrm{O}$ valor da verdade encontrado na Grécia arcaica por Foucault é o mesmo descrito por Detienne em Les Maîtres de Vérité dans la Gréce archaïque. Ver, por exemplo, a seguinte passagem: “A ‘verdade' se institui por meio da aplicação correta, ritualmente realizada, do procedimento. Quando ele preside, no nome dos deuses, o julgamento ordálico, o rei 'diz a verdade' ou melhor, ele veicula a verdade. Como o poeta, como o adivinho, o rei é 'Mestre de verdade'. Nesse plano de pensamento, a 'verdade' está, então, sempre ligada a certas funções sociais; ela é inseparável de certos tipos de homens, de suas qualidades próprias e de um plano real, definido por suas funções na sociedade grega arcaica" (Detienne, Les Maîtres de Vérité dans la Gréce archä̈que, p. 111).
}

${ }^{408}$ Cf. Foucault, Leçon sur la volonté de savoir, aula do dia 10 de fevereiro.

${ }^{409}$ Foucault, Leçon sur la volonté de savoir, p. 99. 
somente aplicar regras e arriscar a verdade. É não esquecer de saber a verdade; é não esquecer a verdade que sabemos" $" 410$.

Mas como, afinal, conhecer essa justiça, essa verdade justa? De acordo com Foucault, a diké será conhecida por meio de três tipos de saber, todos eles importados dos grandes impérios da Mesopotâmia: 1) um saber de observação dos dias e dos astros que indicava, por meio de um calendário oficial, as melhores datas para tomar decisões, para realizar os trabalhos, as batalhas, a semeadura; 2) um saber técnico das quantidades e das medidas que era capaz de estabelecer um sistema de equivalências útil para a arrecadação de impostos e para calcular empréstimos e dívidas; 3) um saber mítico-religioso das origens que recitasse a genealogia e as façanhas dos antepassados e do rei atual de modo a revigorar seu poder ${ }^{411}$. Contudo, nota Foucault, se esse três tipos de saber oriental vão organizar o saber grego e ocidental (saber técnico da agronomia e da medicina que conhecem o momento e a ocasião certa de agir; saber matemático e físico que calcula as quantidades e as medidas; saber das cosmologias, da filosofia e da história que vão atrás da origem, da gênese e da sucessão ${ }^{412}$ ), é preciso estar atento ao deslocamento que ocorre entre saber e poder de um momento e de um lugar a outro da história.

Se nos grandes impérios do Oriente a correlação entre saber e poder era evidente, a produção de saber estava intimamente ligada ao exercício político de poucos indivíduos e aos chefes de Estado, constituindo sua condição de exercício, na Grécia clássica o saber deve pertencer a todos, a todos que pretendem ser justos e que reivindicam dos outros a justiça ${ }^{413}$.

\footnotetext{
${ }^{410}$ Foucault, Leçon sur la volonté de savoir, p. 105.

${ }^{411}$ Cf. Foucault, Leçon sur la volonté de savoir, p. 113.

412 Sobre esses três tipos de saber norteadores do pensamento ocidental, é interessante notar que Foucault afirma que os dois últimos foram os responsáveis pela organização da ciência ocidental a partir das problemáticas da origem e da medida, da sucessão e da quantidade, da ordem do tempo e da ordem numérica. O primeiro tipo de saber, aquele relativo ao momento propício para agir, presente por exemplo na lógica estoica, teria, segundo Foucault, sido colocado à margem. Ele só voltaria a aparecer em circunstâncias bem precisas: tratando-se de estratégia militar, política e revolucionária (Cf. Foucault, Leçon sur la volonté de savoir, p. 108).
}

\footnotetext{
${ }^{413}$ A relação entre saber e poder encontrada nas civilizações do Oriente é descrita da seguinte maneira por Foucault: “o saber se encontra naturalmente localizado nas mãos dos funcionários: o saber é um serviço do Estado e um instrumento político. Daí seu caráter necessariamente secreto. Ele não deve circular e se espalhar. Ele está ligado diretamente à posse do poder". Em seguida, Foucault fala da Grécia: “Ora, é aqui que entra a transformação grega. O saber será dissociado do aparelho do Estado e do exercício direto do poder; ele será separado da soberania política em sua aplicação imediata para se tornar o correlativo do justo" (Foucault, Leçon sur la volonté de savoir, p. 113). Sobre a "democratização" do saber, Foucault dá um exemplo dos artesãos: “Com o artesanato, na Grécia e na Jônia, aparece um tipo de saber cuja distribuição - senão o conteúdo - é muito diferente do que encontramos nos Estados asiáticos: lá, o saber estava ligado ao exercício de uma função política ou a um papel particular do Estado. A extração e o trabalho do metal, a fabricação de objetos preciosos estavam reservados a grupos de escravos, sob a direção e a responsabilidade de funcionários do Estado que deveria conservar seu segredo e monopólio. $O$ artesão grego tem acesso às técnicas de transformação: ele as conhece porque lhe foram ensinadas ou porque descobriu algumas; e conhecendo-as ele as transmite aos outros" (Foucault, Leçon sur la volonté de savoir, p. 120).
} 
Assim, se, por um lado, diferentemente da Grécia arcaica, na Grécia clássica a justiça deixa de ser assunto exclusivamente divino e passa a ser gerida também pelos homens, sai do plano mítico e religioso dos ritos e passa a ter suma importância política para o ordenamento da cidade ${ }^{414}$, por outro lado, contrariamente aos impérios mesopotâmicos, o saber não é considerado um segredo que serve de instrumento somente a quem detém o poder político, mas é colocado em praça pública ao lado da justiça. O que acontece é uma espécie de democratização tanto do conhecimento quanto da justiça. Confirma Foucault: "O saber que era o segredo do poder eficaz vai se tornar a ordem do mundo manifesto, medido, efetuado em sua verdade, cotidianamente e para todos os homens. E a verdade que era memória da regra ancestral, desafio e risco aceito, vai tomar a forma do saber vindo da ordem das coisas e que se conforma a ela"415.

A diké está no mundo, é o princípio imanente de sua ordenação, e para ser conhecida basta que os homens prestem atenção, observem e escutem o mundo ${ }^{416}$. É preciso estar atento à justiça da vida cotidiana: a justiça que ordena os astros, o clima, os ventos, as estações e que determina o momento propício para trabalhar a terra; a justiça que media as trocas de mercadoria, permitindo calcular suas equivalências, e a que media as dívidas entres os homens; a justiça estabelecida pelos calendários que determina os prazos certos para receber e fazer um pagamento. Enfim, arremata Foucault: "é uma justiça de todos os dias que é exercida por todos os homens, a partir do momento que eles trabalham e que realizam trocas"417.

A verdade de uma ação justa não está, portanto, nela se adequar aos costumes, aos rituais que põem em jogo a força e a coragem, mas exige um conhecimento verdadeiro: conhecimento verdadeiro que procura garantir uma relação de igualdade entre os homens, entre as trocas que eles

\footnotetext{
414 Sobre esse novo papel político da justiça, Foucault afirma que a justiça "é um dos meios de fazer reinar a ordem da cidade, não de reconhecer a cada um o que lhe deve naturalmente, mas atar como se deve os laços da cidade, de cuidar que o lugar de cada um se equilibre harmoniosamente com o dos outros" (Foucault, Leçon sur la volonté de savoir, p. 92).

415 Idem, p. 114.

416 É preciso, pois, conhecer o ciclo temporal, saber que ele retorna e estar atento, portanto, ao calendário. É preciso saber que a passagem do tempo faz parte do ciclo das coisas e que Zeus, por exemplo, cuida de recompensar o trabalho dos homens com uma boa colheita (Cf. Foucault, Leçon sur la volonté de savoir, p. 105). É preciso, pois, conhecer “a verdade dos dias e das datas; dos momentos favoráveis; dos movimentos e das conjunções dos astros; dos climas, dos ventos e das estações: ou seja, todo um tipo de saber cosmológico". Mas não só. É também preciso uma teogonia; um saber que ensine a verdade da gênese dos deuses e do mundo, de sua ordem de sucessão e de sua organização como sistema do mundo. Ou seja, todo um tipo de saber sobre a origem e sobre o começo do mundo (Cf. Foucault, Leçon sur la volonté de savoir, p. 106). Assim, para que um julgamento seja justo, confirma Foucault, é preciso que "ele saiba que se funda sobre o exato retorno do tempo, a exata medida das coisas. Não se trata simplesmente de se recordar das regras, de ter thémis [costumes] em memória. É preciso se lembrar das estações e dos tempos; é preciso ter medido os bens. É preciso que esta medida tenha sido feita e que ela permaneça na memória" (Foucault, Leçon sur la volonté de savoir p. 103). Não se trata mais, segundo Foucault, de ter em memória as regras, os costumes e os decretos de Zeus a fím de aplicá-los na ocasião certa, memória exegética, mas de ter em memória a medida das coisas e do tempo a fim de garantir que essa medida seja sempre a mesma, memória contábil.
}

${ }^{417}$ Foucault, Leçon sur la volonté de savoir, p. 111. 
efetivam e entre o que tomam emprestado e o que devem, e conhecimento verdadeiro que garante o momento oportuno para agir. Com isso, conclui Foucault: "o saber se desloca do poder ao controle da justiça" ${ }^{\prime 18}$. O que exatamente significa isso? Que a importância do saber não será tanto a de garantir o exercício do poder político, mas a de garantir as relações de justiça, de ajudar a restituir a ordem, de colocar as coisas em seu devido lugar e tempo, enfim, de garantir que o mundo esteja de acordo com o que deve ser. Resume Foucault: "Estar no verdadeiro será estar no justo, mais do que no poder" ${ }^{19}$. A partir de então, continua o filósofo, a ideia de uma verdade-desafio e a correlação entre saber e poder serão rejeitadas.

Mas, que não nos enganemos com essas formulações de Foucault. Dizer que o saber, na Grécia clássica, se desloca do poder ao controle da justiça, não significa que ele não esteja mais ligado ao poder. $\mathrm{O}$ que acontece é que ele passa a se ligar a um outro tipo de poder, a um novo tipo de autoridade política que não mais a do rei enquanto entidade mítico-religiosa. Assim, se Foucault tem razão que o que muda entre a Grécia arcaica e a Grécia clássica não é só o valor que se atribui à verdade, mas todo o sistema de poder ${ }^{420}$, o que é preciso averiguar é que novo sistema de poder se instaura e de que modo ele se relaciona com a verdade.

\section{A genealogia do sujeito puro de conhecimento e do valor apofântico da verdade}

É a partir dos estudos dos helenistas que Foucault retoma uma série de transformações que marcam a diferença entre o modo de pensar da Grécia arcaica e da Grécia clássica, entre uma e outra maneira de valorizar a verdade e entre dois sistemas de poder distintos.

De acordo com Foucault, a crise agrária dos séculos VII e VI a.C., que envolve tanto o problema da partilha da terra (as inúmeras invasões dóricas deixam a terra dividida em porções desiguais e de maneira inalienável) como do cultivo de terras áridas e inférteis, será responsável por uma série de transformações sociais, econômicas e políticas. Os proprietários mais pobres das terras mais áridas serão os mais prejudicados: como não podem vender suas terras, tornar-se-ão reféns de um esquema de empréstimos e dívidas, o que os deixará cada vez mais pobres. Contra essa situação deteriorante, os camponeses pobres procurarão se defender a partir de um sistema de medidas e de cálculos que garantisse não só um aumento da produtividade da terra, mas que garantisse também relações mais justas no que diz respeito aos pagamentos e aos prazos das dívidas. Além de um novo

\footnotetext{
${ }^{418}$ Foucault, Leçon sur la volonté de savoir, p. 107.

${ }^{419}$ Idem, p. 115.

${ }^{420}$ Cf. Foucault, Leçon sur la volonté de savoir, p. 75.
} 
sistema de medida e de cálculo, outras condições foram essenciais para que os camponeses conseguissem, de alguma maneira, resistir às violências e aos abusos dos mais ricos. A primeira delas diz respeito ao apoio que tiveram da classe dos guerreiros, que, além de bem armada, começava a incarnar a força nas cidades e a representar um novo poder no interior delas. Em segundo lugar, a luta dos camponeses por relações mais justas se intensifica quando os camponeses podem melhorar sua situação por meio do trabalho artesanal; com isso, ganham um pouco mais de dinheiro, passam a comprar mais dos outros artesãos e forma-se, assim, uma espécie de aliança entre camponeses e artesãos contra a aristocracia dos grandes proprietários de terra.

Para Foucault, na Grécia, entre os séculos VII e VI. a.C., é toda uma reconfiguração do cenário político e social que se instaura a partir do conflito entre os mais ricos e os mais pobres. Cenário político que vai passar pela instauração das tiranias com o apoio militar e que vai ter nas leis escritas um meio de propor reformas que melhorem as condições sociais dos camponeses e também dos artesãos. Um cenário, por fim, que vai desembocar na formação das cidades-Estado e no regime democrático ${ }^{421}$.

Obviamente as análises de Foucault sobre as transformações políticas, sociais e econômicas ocorridas nesse período que marcam a passagem da Grécia arcaica para a Grécia clássica são muito mais complexas e ricas do que esse sucinto esboço traçado aqui. Em diversos momentos do curso, por exemplo, Foucault insiste que a instituição da moeda é um dos acontecimentos centrais que deve ser levado em conta para se compreender a nova relação dos homens com a justiça, com a verdade e com o poder ${ }^{422}$. Aqui, contudo, tivemos que deixar de lado essas análises. Como já dissemos, não nos interessa retomar em profundidade os argumentos históricos de Foucault. Importa, antes, apresentar o esquema geral da argumentação a fim de extrair aquilo que se relaciona com nossa questão central: a relação entre sujeito e verdade. Nesse sentido, gostaria de insistir num ponto que, esse sim, toca mais de perto nossa problemática. Ele diz respeito à lei.

De acordo com Foucault, a aparição da lei escrita na Grécia se faz no interior de um acontecimento onde está em questão o poder e a luta pelo poder ${ }^{423}$. Em primeiro lugar, vale notar a oposição entre a lei escrita, nomos, e o modelo anterior da lei, aquele baseado nos costumes e na tradição, thesmos. Uma primeira diferença entre os dois modelos de lei é que a lei não escrita depende da memória para ser conservada e deve ser colocada em prática no momento e na ocasião

\footnotetext{
${ }^{421}$ Cf. Foucault, Leçon sur la volonté de savoir, aula do dia 17 de fevereiro, pp. 111-123.

${ }^{422} \mathrm{Cf}$. principalmente a aula do dia 24 de fevereiro, totalmente dedicada ao estudo da moeda.

${ }^{423}$ Cf. Foucault, Leçon sur la volonté de savoir, p. 144.
} 
adequada. "O bom chefe - assinala Foucault - é aquele que se lembra da regra quando o momento é bom" ${ }^{24}$. Ademais, a lei não escrita só existe e tem atualidade quando é pronunciada, e pronunciada por meio de um ritual; "sua eficácia está ligada ao acontecimento ritualístico de sua enunciação", insiste Foucault ${ }^{425}$. Por fim, em função do caráter não escrito das leis, aqueles que as conservavam na memória detinham um poder: "A memória das regras era uma das riquezas das grandes famílias, uma de suas reservas, um modo de exercício do poder e uma maneira de conservá-10" ${ }^{26}$.

O que difere o nomos do thesmos, porém, não necessariamente é o fato de ser uma lei escrita. É certo que as leis inscritas em pedras ou nos muros e que eram expostas publicamente para que todos pudessem ver quando fosse necessário foram chamadas nomos. Porém, diz Foucault, Heródoto também chama de nomos uma lei que não é escrita; uma lei não escrita, contudo, que é diferente das leis dos costumes principalmente porque é uma lei ensinada, transmitida pela educação, e não uma lei detida por poucos como segredo. Assim, seja como conteúdo da educação, seja como escritura, um aspecto importante do nomos é que ele é um tipo de lei que está sujeita a mudar a partir dos discursos, das discussões, das deliberações e do voto, o que seguramente não acontecia com o thesmos, que era resguardado de qualquer alteração. E apesar desse caráter flexível do nomos, ele tem também o aspecto de algo natural, já que agir de acordo com o nomos é agir da maneira que convém, da maneira que se deve agir, de maneira conveniente, harmoniosa e ajustada ${ }^{427}$.

De acordo com Foucault, a instauração do nomos como estrutura jurídica e política da cidade nasce daquela nova configuração da justiça cantada por Hesíodo, aquela em que a diké permeia a relação entre os homens garantindo uma justa repartição dos bens, uma boa distribuição das riquezas e de seu ciclo e uma certa regularidade entre aquilo que se gasta e aquilo que se tem a receber ${ }^{428}$.

Ora, em Atenas, por meio das reformas propostas por Sólon, se vê claramente a relação entre a instauração de um novo modelo de lei e essa nova configuração da justiça. Segundo Foucault, as reformas de Sólon procuraram pôr fim a uma luta desregrada entre pobres e ricos, mas ao invés de elas terem assegurado uma distribuição da riqueza e das terras, o que elas proporcionaram foi, antes de mais nada, uma distribuição do poder jurídico-político. “O poder não é mais propriedade de

\footnotetext{
${ }^{424}$ Foucault, Leçon sur la volonté de savoir, p. 144.

425 Ibidem.

${ }^{426}$ Idem, p. 145.

${ }^{427}$ Idem, p. 146.

${ }^{428}$ Idem, p. 150.
} 
alguns. Ele pertence a todos", diz Foucault ${ }^{429}$. A não ser os escravos e os estrangeiros, mas também provavelmente as mulheres, todos têm ao menos um pouco de poder, mesmo sendo muito pobres: eles podem participar das assembleias, reclamar justiça de outros cidadãos e se defender de julgamentos de condenação diante da assembleia popular. Com Sólon, será, então, o nomos o responsável por assegurar esse poder a todos: se alguém praticar injustiça abusando de seu poder, deverá ser punido. Por outro lado, se alguém se enriquecer de maneira não justa, o nomos não tem nada com isso: caberá aos deuses a punição ${ }^{430}$. Desse modo, conclui Foucault: “O nomos é o nome que recebe um princípio de distribuição de poder que serve para manter os princípios de distribuição de riqueza"431. Ou seja, é um princípio que assegura uma repartição mais igualitária do poder político, mas que mantém intactas as relações econômicas desiguais: lei inviolável que prescreve a repartição do poder com o objetivo de manter um certo tipo de relação econômica ${ }^{432}$.

Dessa separação entre política e economia ou entre poder e riqueza, manifestada na figura do nomos, Foucault tira um desdobramento que é o que mais nos interessa aqui, mas que é, ao mesmo tempo, um dos pontos menos trabalhados pelo filósofo. Na conclusão da aula do dia 3 de março, depois de 5 aulas expondo a situação da Grécia entre os séculos VII e VI a.C., tendo falado da crise agrária, das lutas de classe que a sucederam e da instituição da moeda e do nomos, Foucault indica que tipo de sujeito surge com essas transformações.

De acordo com Foucault, o nomos exige um sujeito neutro; o discurso da lei não é privilégio nem dos mais ricos, nem dos poucos que detêm o poder político. Isso porque, como vimos, o nomos se mantém indiferente à economia (procura somente constatá-la e registrá-la, nunca contestá-la) e procura mais distribuir o poder político do que concentrá-lo. O sujeito de enunciação do nomos, portanto, deve consistir nessa figura que é uma suposta "página em branco", nesse sujeito que não tem a cara de ninguém, nem dos mais ricos, nem dos mais poderosos, mas que pode ser todo mundo: sujeito universal. E com que tipo de verdade esse sujeito do nomos se relaciona? Uma verdade também sem cara e sem rosto: uma verdade universal e objetiva, aquela que constata a ordem justa do mundo ${ }^{433}$.

A esse sujeito neutro que vai aos poucos delineando o que virá a ser o sujeito de conhecimento de Aristóteles, Foucault ainda acrescenta um outro predicado: a pureza. Categoria

\footnotetext{
${ }^{429}$ Foucault, Leçon sur la volonté de savoir, p. 151.

${ }^{430}$ Idem, p. 154.

431 Ibidem.

${ }^{432}$ Cf. Foucault, Leçon sur la volonté de savoir, p. 154.

${ }^{433}$ Cf. Foucault, Leçon sur la volonté de savoir, p. 157.
} 
que adquire um novo sentido a partir da Grécia clássica também em função das mudanças jurídicas ocorridas no período, principalmente em função da instauração do nomos e de certa concepção jurídica do indivíduo que implicará novas problemáticas em torno da morte e das categorias de puro e impuro ${ }^{434}$.

As ideias defendidas por Foucault mais uma vez não são de sua autoria; em sua maior parte são tomadas de Louis Moulinier que em 1950 defende uma tese na Sorbonne intitulada Le Pur et l'Impur dans la pensée et la sensibilité des Grecs jusqu'à la fin du VIème siècle avant J.- C. e que em 1955 publica Orphée et l'Orphisme à l'époque classique.

Foucault defende que as transformações ocorridas na categoria de puro e impuro na passagem da Grécia arcaica para a Grécia clássica podem ser analisadas a partir de duas oposições: a oposição entre criminalidade e inocência e a oposição entre ignorância e saber.

Em Homero, isto é, para o pensamento arcaico, a purificação está sempre ligada a um ritual que serve para lavar o sangue e a sujeira que se adquire nos combates, nas lutas, nos massacres. Mas não se trata de se purificar de um crime cometido, de uma falta ou de um excesso realizado, afinal, esclarece Foucault, em Homero, nem o crime, nem o criminoso são considerados impuros. Os rituais de purificação não servem para expugar uma impureza, mas para marcar ritualisticamente dois momentos e dois lugares sócio-religiosos distintos e heterogêneos: um profano e outro sagrado, um do massacre e o outro da festa, um da morte e outro da vida, um da esfera do cotidiano e outro da esfera do pertencimento aos deuses ${ }^{435}$. Na Grécia clássica, afirma nosso autor, os ritos de purificação terão outra utilidade: não mais marcar a passagem entre profano e sagrado, mas fazer com que a sujeira desapareça. $\mathrm{O}$ assassinato e o crime deverão ser qualificados como impuros e o ritual de purificação deverá cuidar para tornar puro o impuro. A partir de então, conlui Foucault, é toda uma moral da falta e uma nova vontade de saber que estarão em jogo ${ }^{436}$.

$\mathrm{Na}$ Grécia clássica, de acordo com Foucault, será por meio da legislação, como a de Sólon e Dracon, por exemplo, que trata de assuntos relativos à morte, como a herança, os ritos funerários e o assassinato, que o poder político irá desenhar uma nova forma de individualidade ${ }^{437}$. Diz Foucault: "É tomando o controle dos efeitos econômicos e sociais da morte que o poder político

\footnotetext{
${ }^{434}$ Cf. Foucault, Leçon sur la volonté de savoir, p. 168 e p. 172.

${ }^{435}$ Cf. Foucault, Leçon sur la volonté de savoir, p. 162.

${ }^{436}$ Cf. Foucault, Leçon sur la volonté de savoir, p. 163.

${ }^{437}$ Foucault, Leçon sur la volonté de savoir, p. 168.
} 
suscitou, a título de efeito, esta forma de individualidade com a qual ainda estamos familiarizados"438.

A fim de assegurar aos ricos suas fortunas e terras, a legislação deve garantir somente a certos indivíduos, e não mais a toda família, os direitos de herança. Segundo Foucault, o que se observa é que a individualidade começa a se desenhar como forma da propriedade ${ }^{439}$. Mas, se a lei assegura a riqueza individual dos mais ricos, por outro lado, irá assegurar a todos a possibilidade e o direito de cultuar os mortos. Sólon, por exemplo, limita os ritos mágico-religiosos mais ostensivos e duradouros que eram privilégios dos heróis e dos aristocratas, a fim de tornar o culto à imortalidade um direito de todos. Sendo assim, assegura Foucault: "a imortalidade da alma deve ser considerada, antes de mais nada, uma conquista de classe" ${ }^{440}$. Finalmente, no que diz respeito à jurisdição do assassinato, a fim de pôr termo às lutas interfamiliares e aos atos indefinidos de vinganças, o poder político passa a exercer uma série de qualificações jurídico-morais dos criminosos e do crime. Em primeiro lugar, torna-se legítimo matar os assassinos; em segundo lugar, passa-se a qualificar o crime em função da intenção do criminoso (homicídio voluntário, involuntário, em legítima defesa) e se estabelece uma série de práticas de exclusão dos criminosos; por fim, continua Foucault, o julgamento dos crimes deve ter função purificadora, deve purificar a sujeira intrínseca a eles.

Assim, se, antes para o pensamento arcaico, a jurisdição dada pelas leis e regras da tradição exigiam que, diante de um crime, fossem realizados os rituais adequados e esperados, agora, na Grécia clássica, o poder intervém juridicamente, por meio dos magistrados e tribunais, exercendo uma qualificação jurídico-religiosa (isto é, julgando jurídica e moralmente) dos atos e daqueles que os cometeram, a partir das categorias de puro e impuro. Assegura Foucault: “A ligação pureza/ inocência ou impureza/crime não é traço de arcaísmo mas, ao contrário, formação relativamente recente no sistema jurídico-religioso dos gregos" ${ }^{441}$.

É de se notar, contudo, que a centralidade dada à categoria de impureza não é a causa das práticas de exclusão dos criminosos, como se primeiro houvesse indivíduos impuros que cometessem crimes e que seriam, posteriormente, excluídos. Ao contrário, diz Foucault. É porque o crime deve ser excluído que o criminoso é considerado impuro. Impuro, portanto, é o nome que se dá ao que não podia ser tolerado, ao que ameaçava e punha em risco a cidade, ao que devia ser excluído: o crime e o criminoso. São as práticas de exclusão do criminoso que são constitutivas da

\footnotetext{
${ }^{438}$ Foucault, Leçon sur la volonté de savoir, p. 170.

${ }^{439}$ Cf. Foucault, Leçon sur la volonté de savoir, p. 169.

${ }^{440}$ Foucault, Leçon sur la volonté de savoir, p. 169.

${ }^{441}$ Idem, p. 172.
} 
separação entre puro e impuro, e não o contrário. A crença na impureza, crença, aliás, mal articulada e sem figura imaginária, diz Foucault ${ }^{442}$, é efeito de práticas de exclusão. Que tipos de práticas? Aquelas que colocam o criminoso fora de todo o espaço do nomos não só por meio da morte e do exílio, mas proibindo o criminoso de se aproximar dos espaços onde se dão os rituais, da praça pública e da cidade.

Impuro, então, é aquele indivíduo que por ter cometido um crime não pode mais usufruir da justiça garantida pelo nomos; aquele que precisamente por não ter respeitado o nomos é uma ameaça à cidade e à sua ordem e que, por esse motivo, deve ser excluído e qualificado como impuro. Percebe-se, então, de que modo as transformações ocorridas na categoria de puro e impuro implicam duas oposições: a oposição entre criminalidade e inocência e a oposição entre ignorância e saber.

No que diz respeito à oposição criminalidade/inocência, vê-se configurar a ideia do crime como impureza e da inocência como pureza, ou ainda: puro é respeitar o nomos e conhecer sua verdade; ignorá-lo e transgredi-lo é impuro. É por esse motivo que é importante, como insiste Foucault, descobrir se houve mesmo um crime e quem o cometeu. Afinal, o crime produz uma sujeira e uma impureza que devem ser expurgadas. Como expurgar a impureza? Julgando e condenando o criminoso, de modo a fazer valer a verdade da justiça e, com isso, voltar ao estado de pureza. Essa é a conclusão de Foucault: “A demonstração da verdade torna-se uma tarefa política. A impureza e seus efeitos trazem consigo a exigência de uma pesquisa do que aconteceu"443.

No que diz respeito à oposição ignorância/saber, perecebe-se certa relação entre, de um lado, a pureza e a verdade e, de outro, a impureza e a ignorância. É, pois, quando se ignora, voluntária ou involuntariamente, a verdade do nomos, verdade da medida, da distribuição e da quantidade (verdades de justiça, se assim podemos dizer), que se é qualificado de impuro, e é quando se faz valer a verdade da justiça que se é puro. "O impuro não pode ter acesso à verdade", confirma Foucault ${ }^{444}$, a verdade só é acessível sob a garantia da pureza ${ }^{445}$.

Assim, se a partir da análise da crise agrária, do aparecimento de um novo regime político, da instauração da moeda e do nomos, Foucault havia delineado certo tipo de sujeito correlato a essas transformações, um sujeito neutro e universal, agora, a partir de uma análise histórica dos domínios jurídicos e religiosos que lidam com a questão da morte, o filósofo acrescenta mais uma

\footnotetext{
${ }^{442}$ Cf. Foucault, Leçon sur la volonté de savoir, p. 173.

${ }^{443}$ Foucault, Leçon sur la volonté de savoir, p. 178.

${ }^{444}$ Idem, p. 173.

${ }^{445}$ Cf. Foucault, Leçon sur la volonté de savoir, p. 186.
} 
qualidade a esse novo sujeito que nasce na passagem da Grécia arcaica para a Grécia clássica: a pureza. E se, no que tange à relação entre o sujeito e a verdade, vimos acima que para ter acesso à verdade da justiça o sujeito, já em Hesíodo, precisava estar atento ao mundo, precisa vê-lo e ouvilo, agora é a percepção que é convocada para apreender a verdade. Nada de experimentar a verdade como uma prova, de jurá-la ou de se sacrificar fisicamente em seu nome. A verdade deve ser considerada um dado objetivo a que o sujeito, puro e neutro, tem acesso pela percepção: além da verdade do mundo estar sempre à vista, o nomos também deve se manter aos olhos (por meio da escrita) e aos ouvidos (por meio da educação) de todos; além disso, a verdade dos fatos que indique, por exemplo, se um crime aconteceu e quem o cometeu, deve também ser verificada empiricamente por meio de um inquérito que conte com testemunhas que relatem o que viram e ouviram.

Ora, o cenário parece estar montado. O sujeito de conhecimento de Aristóteles pode entrar em cena. As condições que possibilitam o seu valor já estão dadas. Com isso, retomemos o que dizíamos antes dessa digressão que procurou percorrer as linhas gerais de certa história da verdade, ou dessa genealogia, realizada por Foucault em seu primeiro curso no Collège de France. Tentemos resumir de que modo Foucault se apropriou de alguns princípios nietzschianos a fim de compreender o aparecimento da vontade de saber de Aristóteles, de certo tipo de sujeito de conhecimento e de certa concepção de verdade.

A partir do princípio nietzschiano da exterioridade, que afirma que por trás do saber há outra coisa que não o saber, Foucault procurou investigar práticas não discursivas que foram correlatas ao aparecimento de certa noção de verdade. Em consonância com as teses dos helenistas, segundo as quais a Grécia arcaica é marcada por uma nova concepção de medida, as práticas não discursivas investigadas por Foucault estão ligadas a essa nova concepção de justiça e provêm do campo das relações sociais, econômicas, políticas e religiosas. O filósofo, então, procurou compreender a lei de coexistência entre esses acontecimentos da ordem não discursiva e a produção de verdade realizada no domínio do discurso filosófico de Aristóteles. Ou seja, procurou mostrar, contra esse mesmo discurso, que não é a partir de uma univocidade subjetiva que a verdade é possível ${ }^{446}$, mas que aquilo que é considerado verdadeiro numa época depende dos acontecimentos da ordem política que permitem uma certa concepção da ordem do mundo, das coisas e dos homens. Com isso, Foucault também seguiu o princípio nietzschiano da dispersão que mostra que não é um sujeito que porta a verdade, mas que a constituição da verdade é dependente, antes de mais nada, de uma multiplicidade de acontecimentos exteriores a ela. Por fim, quanto ao princípio nietzschiano da

${ }^{446}$ Foucault, Leçon sur la volonté de savoir, p. 192. 
ficção que afirma que a verdade não passa de um efeito de ficção e de erro, ao mostrar que a verdade tem uma história, Foucault defendeu que ela não passa de uma construção. Desse modo, não só a concepção de verdade enquanto prova é exemplo de que a verdade nem sempre é pensada como valor apofântico, mas a ideia de que a própria concepção de verdade enquanto valor de verdade é também um construto evidencia que a verdade é uma ilusão: é efeito, e não princípio, de uma vontade de saber específica. Que a verdade, mais do que uma verdade, é aquilo que se aceita como verdade.

A verdade como interpretação: o discurso filosófico como ficção

Mas atenção. Dizer que, para Foucault, toda verdade não passa de uma ilusão não significa dizer que o filósofo negue a existência de verdades objetivas e universais. Em 1981, o filósofo rebate as possíveis acusações contra esta ideia e afirma categoricamente: "Todos aqueles que dizem que para mim a verdade não existe são espíritos simplistas" ${ }^{447}$. Do mesmo modo que, como vimos, o filósofo não nega a existência do sujeito e do cogito, tampouco nega a existência de verdades. Ele simplesmente as deixa de lado para se perguntar sobre a maneira como atribuímos valor às verdades. Mas, se é assim, se podemos dizer que Foucault coloca entre parênteses não só a existência de um sujeito universal de conhecimento, mas também a existência de verdades universais, em que sentido podemos compreender outra afirmação do filósofo, feita numa entrevista de 1976, que diz o seguinte: "é da verdade que eu me ocupo, sou, apesar de tudo, filósofo" ${ }^{448}$ ? Afinal, Foucault põe entre parêntese a verdade ou se ocupa dela?

As duas coisas. Por um lado, ele contorna a verdade com valor objetivo e universal; não se ocupa com ela com o intuito de investigar o valor de verdade daquilo que foi dito, nem tampouco com o intuito de analisar as condições lógicas e formais de possibilidade que permitem ao sujeito o conhecimento verdadeiro. Por outro lado, na medida em que pretende conhecer a vontade de verdade, a maneira como nos relacionamos de modo interessado com ela, atribuindo-lhe certo valor, podemos dizer que Foucault, de certo modo, se ocupa com a verdade.

No artigo escrito para o dicionário Huisman dos filósofos, Foucault comenta um dos aspectos de seu método que pretende investigar a relação entre verdade e sujeito. Afirma o filósofo, confirmando o que dissemos acima:

\footnotetext{
${ }^{447}$ Foucault, "Le souci de la vérité", in DE II, p. 1488.

${ }^{448}$ Foucault, “Questions à Michel Foucault sur la géographie”, in DE II, pp. 30-1.
} 
Tomar como fio condutor [...] a questão da relação entre sujeito e verdade implica certas escolhas de método. Primeiramente um ceticismo sistemático no que diz respeito a todos os universais antropológicos, o que não significa que rejeitamos todos de saída, em bloco e de uma vez por todas, mas que é preciso admitir desta ordem somente o que for rigorosamente indispensável; tudo o que nos é proposto ao nosso saber com validade universal, como a natureza humana ou as categorias que podemos aplicar ao sujeito, deve ser posto à prova e analisado [...]. A primeira regra de método para esse tipo de trabalho é então a seguinte: contornar o tanto que puder, para os interrogar em sua constituição histórica, os universais antropológicos (e bem entendido também aqueles de um humanismo que faria valer os direitos, os privilégios e a natureza de um ser humano como verdade imediata e intemporal do sujeito). É preciso também inverter o empreendimento filosófico que vai em direção do sujeito constituinte que deve dar conta de todo objeto de conhecimento em geral; trata-se, ao contrário de ir na direção das práticas concretas por meio das quais o sujeito é constituído na imanência de um domínio de conhecimento. Ainda aí, é preciso atenção: recusar o recurso filosófico a um sujeito constituinte não é fazer de conta que o sujeito não exista ou abstraí-lo em benefício de uma objetividade pura; esta recusa visa fazer aparecer os processos próprios a uma experiência onde o sujeito e o objeto "se formam e se transformam" um em relação com o outro e em função do outro ${ }^{449}$.

Na medida em que o que interessa a Foucault é fazer uma investigação da vontade de verdade e não propriamente da verdade, sua história da verdade não significa um puro relativismo: em nenhum momento o filósofo afirma que não existe verdade ${ }^{450}$. O que faz Foucault é mostrar o valor que está por trás das verdades, mostrar por que e como são valorizadas, em função de que interesses e de quais estratégias. Ou seja, no fim das contas, a história da verdade realizada por nosso autor, mais do que uma história da verdade propriamente dita, é uma história do valor que se atribui à verdade. Jogando com as palavras: não lhe interessa questionar o valor de verdade das verdades, mas de questionar a verdade enquanto valor. Não lhe interessa um questionamento sobre as condições de possibilidade de um conhecimento verdadeiro, mas as condições de aceitabilidade do conhecimento que é tido como verdadeiro ${ }^{451}$. Confirma o filósofo na aula inaugural $A$ ordem do discurso:

Certamente, se nos situamos no nível de uma proposição, no interior de um discurso, a separação entre o verdadeiro e o falso não é nem arbitrária, nem modificável, nem institucional, nem violenta. Mas se nos situamos em outra escala, se levantamos a questão de saber qual foi, qual é constantemente, através de nossos discursos, essa vontade de verdade que atravessou tantos séculos de nossa história, ou qual é, em sua forma muito geral, o tipo de separação que rege nossa vontade de saber, então é talvez algo como um sistema de exclusão (sistema histórico, institucional e constrangedor) que vemos desenhar-se ${ }^{452}$.

${ }^{449}$ Cf. Foucault, "Foucault”, in DE II, p. 1453.

450 Francis Wolff, em “Foucault, l'Ordre du Discours et la Vérité", também defende que Foucault não é um relativista, pois sua história da verdade é, antes, uma história da vontade de verdade. Segundo Wolff, na aula inaugural do Collège de France, não se trata mais de pensar a subjetividade simplesmente em suas condições intrínsecas e a priori de possibilidade de conhecimento, mas de pensar como a constituição do sujeito que conhece é tributária de determinada vontade de conhecer a verdade. No que diz respeito às condições de possibilidade do conhecimento, trata-se, pois, de passar de uma análise das estruturas formais e lógicas do indivíduo que conhece para uma investigação acerca da vontade de conhecer a verdade. E se no primeiro caso as condições de possibilidades do conhecimento são universais e a-históricas, a vontade de verdade será sempre histórica e variável. Neste contexto, afirma Wolff: "A questão não é mais: o que distingue o discurso verdadeiro do discurso falso?; mas: o que qualifica a verdade ser socialmente desejável? Dito de outro modo: Por que dizer a verdade? O que constrange todos estes discursos ao verdadeiro mais do que a outra forma de legitimidade socialmente reconhecida?" (Wolff, "Foucault, l'Ordre du Discours et la Vérité" (p. 424).

${ }^{451}$ Cf. Foucault, “Qu'est-ce que la critique?”, p. 48.

452 Foucault, A ordem do discurso, p. 14. 
Assim, no que tange à passagem de certo regime discursivo anterior à filosofia ao discurso filosófico clássico, o que interessa a Foucault, portanto, é observar a modificação que neste momento ocorre na vontade dos indivíduos em suas relações com a verdade. Observar por que se passa a desejar, aceitar e legitimar o discurso verdadeiro, que diz a verdade daquilo que é, mais do que discurso potente, eficaz ou crível. Por que passar do rei de justiça ao Direito, da sofística e da retórica à Filosofia, da poesia à História, da adivinhação à Física. Por que reconhecer na verdade daquilo que é dito, e não no modo de dizer, a maior preciosidade do discurso. Por que, enfim, legitimar o discurso verdadeiro realizado por um sujeito de conhecimento puro e neutro, mais do que um discurso realizado por um sujeito cuja vontade não é tanto uma vontade de verdade, mas, antes de tudo, uma vontade de potência, eficácia ou beleza. Observar, enfim, por que o "sofista é enxotado" $" 453$.

Ora, em todas essas problemáticas que interessam a Foucault é evidente o eco nietzschiano. Lembremos, pois, que a oposição proposta no curso Leçon sur la volonté de savoir entre Aristóteles e Nietzsche apontava justamente para a diferença entre um conhecimento concebido como relação imediata com a verdade (Aristóteles) e a concepção de um conhecimento que na sua relação com a verdade está sempre mediado por certo interesse, isto é, por algo que é exterior à própria verdade e ao próprio conhecimento (Nietzsche). Neste contexto, é preciso compreender que o sofista é enxotado justamente no momento em que o discurso verdadeiro não é mais o "discurso precioso e desejável”, valorizado em seu efeito de poder, pronunciado por quem tem direito e por um ritual específico, mas é um discurso objetivo; momento em que a verdade não é mais vista como algo a ser jurado ou desafiado, mas é procurada objetivamente no mundo; quando "a verdade se deslocou do ato ritualizado, eficaz e justo, de enunciação, para o próprio enunciado: para seu sentido, para sua forma, seu objeto, sua relação a sua referência", confirma Foucault em $A$ ordem do discurso ${ }^{454}$. Os sofistas são, nesse sentido, a última expressão do pensamento arcaico banido pelo pensamento clássico. Não é à toa que é justamente em Aristóteles, o pai de nossa vontade de saber e do valor apofântico da verdade, que Foucault localiza a desqualificação do discurso sofístico ${ }^{455}$. Também não é por acaso que, por se contrapor à noção de verdade de Aristóteles, o discurso dos sofistas tenha vizinhanças com as concepções nietzschianas da verdade e do conhecimento, e que o próprio

\footnotetext{
${ }^{453}$ Foucault, A ordem do discurso, p. 15.

454 Ibidem.

${ }^{455}$ Cf. Foucault, Leçon sur la volonté de savoir, pp. 31-50.
} 
Foucault valer-se-á do método sofístico a fim de descrever o que ele mesmo faz enquanto filósofo ${ }^{456}$.

A oposição entre duas maneiras distintas de conceber a verdade, uma que a questiona em seu valor de verdade e outra que busca compreendê-la enquanto efeito de interesse, é de fundamental importância para entendermos as teses de Foucault. Vimos que essa oposição é aquela que o filósofo propõe entre as concepções de verdade de Aristóteles e Nietzsche e as do pensamento grego arcaico e clássico. Mas esses não são os únicos exemplos. Ao longo de todo seu trabalho, Foucault nos dá diferentes variantes dessa oposição. Em seus últimos escritos, por exemplo, a oposição entre conhecimento de si e cuidado de si irá retomar a distinção entre um conhecimento que pretende ter acesso a uma verdade objetiva e neutra de si mesmo e um conhecimento inserido num contexto mais amplo de interesses por si mesmo, cuja finalidade não é tanto apreender uma "verdade verdadeira" de si, mas uma verdade que traga alguma modificação do sujeito ${ }^{457}$. O tema da parrhesia, o franco-falar, núcleo dos dois últimos cursos do Collège de France, de 1983 e 1984, aponta para a mesma oposição. Pelo menos é isso o que Foucault deixa claro em uma conferência realizada nos Estados Unidos em 1983. Diz Foucault:

eu diria que a problematização da verdade é o que caracteriza tanto o fim da filosofia pré-socrática quanto o início do tipo de filosofia que ainda hoje é a nossa. Essa problematização da verdade tem dois lados, dois grandes aspectos. Um lado está preocupado em assegurar que o processo de raciocínio está correto para determinar se uma declaração é verdadeira (ou preocupar-se com a nossa

456 Indagado sobre a proximidade entre seu trabalho e o dos sofistas, que estão mais preocupados com a verossimilhança do que com a verdade, Foucault responde: “Ah, nisso estou radicalmente ao lado dos sofistas. [...] Acho que os sofistas são muito importantes. Porque temos aí uma prática e uma teoria do discurso que é essencialmente estratégica; estabelecemos discursos e discutimos, não para chegar à verdade, mas para vencê-la. É um jogo: quem perderá, quem vencerá? [...] se para os sofistas falar, discutir, é procurar conseguir a vitória a qualquer preço, mesmo ao preço das mais grosseiras astúcias, é porque, para eles, a prática do discurso não é dissociável do exercício do poder. Falar é exercer um poder, falar é arriscar seu poder, falar é arriscar conseguir ou perder tudo [...]. parece-me igualmente importante nos sofistas essa ideia de que o logos, enfim, o discurso, é algo que tem uma existência material. Isto quer dizer que nos jogos sofísticos, uma vez que uma coisa é dita, ela foi dita; no jogo entre os sofistas, discute-se "você disse tal coisa". Você a disse e fica amarrado a ela pelo fato de a ter dito. Não pode mais libertar-se dela. Isso ocorre não em função de um princípio de contradição com o qual os sofistas pouco se importam, mas de certa maneira, porque agora que se disse está lá materialmente. [...] eles jogaram muito com essa materialidade do discurso [...]. Então a materialidade do discurso, o caráter factual do discurso, a relação entre discurso e poder, tudo isso me parece um núcleo de ideias que eram profundamente interessantes, que o platonismo e o socratismo afastaram totalmente, em proveito de uma certa concepção do saber (Foucault, A verdade e as formas jurídicas, pp.140-1).

\footnotetext{
${ }^{457}$ Numa conferência realizada em Berkeley, em 1980, Foucault parece retomar o mote do primeiro curso no Collège de France, que punha Aristóteles e Nietzsche como dois paradigmas distintos para conceber nossa relação com a verdade. Mas, se no curso de 1971 a preocupação de Foucault ainda era compreender como nos relacionamos com as verdades das coisas do mundo em geral, sabemos que, a partir da década de 80, nosso autor tem especial interesse pela constituição da subjetividade e, portanto, pela maneira como atribuímos e nos relacionamos com a verdade de nós mesmos. Será contrapondo a experiência moral descrita por um estoico e por um cristão que Foucault apontará para duas maneiras distintas do indivíduo se relacionar com a verdade de si mesmo. Em Cassiano, monge cristão, vemos um sujeito preocupado exclusivamente com o conhecimento da verdade; um sujeito que deve dizer a verdade de si mesmo tendo em vista somente o conhecimento verdadeiro daquilo que se é. Em Sêneca, por outro lado, aparece um sujeito que quer conhecer a verdade de si, não por um interesse puramente epistemológico, mas em função de um interesse prático: é tendo em vista a liberdade e a ação que o indivíduo quer conhecer a verdade de si mesmo. Assim, se para Cassiano o que está por trás do conhecimento da verdade de si mesmo é a vontade de conhecer uma verdade pura, em Sêneca reconhecemos que por trás da busca de uma verdade interior está, antes de mais nada, a vontade de conhecer uma verdade que, de algum modo, leve à ação (Cf. Foucault, "Verdade e subjetividade”, p. 218).
} 
capacidade de ter acesso à verdade). E o outro lado está preocupado com a questão: Qual é a importância para o indivíduo e para a sociedade de dizer a verdade, de conhecer a verdade, de ter pessoas que dizem a verdade, bem como saber como reconhecê-las? No lado que se preocupa em determinar como garantir que uma afirmação é verdadeira temos as raízes da grande tradição da filosofia ocidental, que eu gostaria de chamar de "analítica da verdade". E no outro lado, preocupado com a questão da importância de dizer a verdade, de saber quem é capaz de dizer a verdade, e saber por que devemos dizer a verdade, temos as raízes do que poderíamos chamar a tradição "crítica" no Ocidente ${ }^{458}$.

Mas, a oposição entre uma verdade pura e neutra, de um lado, e a verdade interessada, de outro, não serve só de mote a uma história da verdade ou uma história da filosofia em Foucault. Essa oposição é também aquela que nos permite pensar a especificidade do trabalho filosófico do próprio Foucault. Assim, se na última citação feita acima, Foucault afirma que há, de um lado, uma tradição que pensa a verdade com a preocupação de compreender como temos acesso à verdade, a tradição da analítica da verdade, e, de outro lado, uma tradição que se preocupa em compreender a importância de dizer a verdade, a tradição crítica, o que cabe a nós, agora, é averiguar de que modo Foucault situa-se nessa segunda tradição e de que modo ele mesmo se relaciona com a verdade. Ou seja, averiguar de que modo sua história da verdade não se enquadra nos moldes de uma analítica da verdade, mas de uma crítica.

Antes, porém, de tratar o caráter crítico do pensamento de Foucault, precisamos retomar o problema da verdade enquanto ilusão. Afinal, é somente no interior de um questionamento acerca do valor que atribuímos à verdade e da verdade como uma ilusão que chegaremos à crítica.

O caso de Mendel, lembrado por Foucault na aula inaugural do Collège de France, nos parece um exemplo paradigmático para mostrar que apesar de conceber a verdade como ilusão, nosso autor não é um relativista. De acordo com Foucault, Mendel embora tenha falado uma verdade sobre o traço hereditário, sua regularidade estatística que passa de geração a geração e é transmitida pelo sexo, verdade que o filósofo reconhece como objetiva e universal, não foi valorizado no que dizia, isto é, em meados do século XIX, o que ele dizia não era valorizado como verdade. Mendel, diz Foucault retomando uma expressão de Canguilhem, “dizia a verdade, mas não estava "no verdadeiro""459.

A expressão "estar no verdadeiro" precisa bem o domínio de interesse de Foucault. Como temos insistido, não cabe ao filósofo discutir o valor de verdade dos discursos analisados, por mais que ele acredite no valor de verdade de algumas proposições, como é o caso de Mendel, mas compreender qual é o discurso considerado verdadeiro, compreender o que é valorizado como verdade, o que é considerado "estar no verdadeiro" e o que está fora e é excluído desse domínio.

\footnotetext{
${ }^{458}$ Foucault, “Discurso e verdade: seis conferências”, p. 112.

${ }^{459}$ Foucault, A ordem do discurso, p. 35.
} 
Ora, para Foucault, é na medida em que aquilo que é considerado verdade não necessariamente é verdadeiro, mas somente valorizado como tal, que podemos dizer que a verdade é uma ilusão. Ela é uma ilusão não porque não se refere a nada de real, não porque não exista adequação possível entre nossas representações subjetivas e os objetos, mas porque aquilo que, numa determinada época e num determinado lugar, é dito ser verdadeiro não passa de um modo, dentre outros possíveis, de valorizar a verdade. A verdade é uma ilusão não porque não exista verdade, mas porque o que é considerado verdade aponta, antes de mais nada, não para uma verdade pura e objetiva, mas para uma certa maneira de valorizar a verdade, para certa vontade de verdade.

Mas, se é assim, o que dizer do discurso do próprio Foucault? É ele um discurso legitimado, aceito em sua época e tido como verdadeiro? Se sim, a verdade de seu discurso é também uma verdade ilusória ou pretende ser uma verdade verdadeira? Será que sua história da verdade aponta para uma história verdadeira da vontade de verdade ou, antes, para um conhecimento interessado?

A fim de enfrentarmos a questão do valor de verdade do discurso do próprio Foucault, podemos retomar algumas palavras do filósofo. Diz ele:

Pratico um tipo de ficção histórica. De uma certa maneira, sei muito bem que aquilo que digo não é verdade [...]. Sei muito bem que o que eu fiz é, do ponto de vista histórico, parcial, exagerado. Mas, meu livro teve um efeito sobre a maneira que as pessoas percebem a loucura. [...] Procuro provocar uma interferência entre a nossa realidade e aquilo que sabemos de nossa história passada. Se consigo, esta interferência produzirá efeitos reais sobre a nossa história presente ${ }^{460}$.

Ora, o que vemos aqui? Vemos Foucault defendendo que não só o conteúdo de sua pesquisa diz respeito a uma história da verdade como ilusão, mas que a própria forma de sua pesquisa referese ela mesma a uma verdade ilusória. O filósofo é enfático: o que ele faz é uma ficção, é, do ponto de vista histórico, parcial e exagerado. O fato de suas pesquisas históricas serem parciais e exageradas, contudo, não deve comprometer o valor de seu trabalho. Afinal, o valor do discurso foucaultiano não deve ser encontrado no valor de verdade daquilo que é dito, mas nos efeitos reais que ele provoca. Ou seja, não está tanto em seu aspecto epistemológico, mas em seus efeitos éticos e políticos. Sua utilidade não é a apreensão de uma verdade pura, objetiva e neutra, nem a

\footnotetext{
${ }^{460}$ Foucault, "Foucault étudie la raison d'État", in DE II, p. 859. Numa conferência de 1978, que retomaremos a seguir na conclusão desse trabalho, Foucault também afirma que sua prática histórico-filosófica é uma ficção. Seu esforço, confessa, é o de fazer sua própria história, "fabricar como por ficção a história que seria travestida pela questão das relações entre as estruturas de racionalidade que articulam o discurso verdadeiro e os mecanismos de sujeição que lhe estão ligados" (Foucault, "Qu'est-ce que la critique?", p. 46, grifo nosso). Em 1973, numa das conferências do Rio de Janeiro, A verdade e as formas jurídicas, é da seguinte maneira que o filósofo descreve seu empreendimento históricocrítico: "meu discurso não procura obedecer as mesmas leis de verificação que regem a história propriamente dita, uma vez que esta tem como único fim dizer a verdade, dizer o que se passou, no nível do elemento, do processo, da estrutura, das transformações. Eu diria, de maneira mais pragmática, que, no fundo, minha máquina é boa; não na medida em que ela transcreve ou fornece o modelo do que se passou, e sim na medida em que ela consegue dar do que se passou um modelo tal que permita que nos libertemos do que se passou" (p. 157).
} 
contemplação, nem o conhecer por conhecer. Seu interesse não é dizer a verdade, mas, antes de mais nada, modificar os sujeitos: modificar seus modos de pensar, de agir e de ser.

Assim, se, por um lado, o conteúdo do discurso de Foucault ensina que existem duas maneiras de se relacionar com a verdade, uma que a quer pura e neutra e outra que quer utilizá-la de modo conscientemente interessado, por outro lado, não podemos esquecer que esse discurso foucaultiano sobre a verdade é ele mesmo interessado, exagerado, parcial, perspectivo e ilusório. O discurso foucaultiano, na esteira de Nietzsche e mais próximo do pensamento grego arcaico do que do clássico, pretende ser mais amplo do que um ensinamento meramente teórico e epistemológico; ele deve também, e principalmente, ser útil para a vida prática, ética e política dos indivíduos. O estatuto verdadeiro que ele contém e que a ele se atribui, portanto, não provém do fato de ser um discurso apofântico, utilizando os termos de Foucault ao falar de Aristóteles, mas um discurso de poder, falando em termos foucaultianos e nietzschianos. Isso, contudo, nos leva a pôr uma série de questões: Quais os interesses que estão por trás do discurso foucaultiano; Que tipo de relação de poder ele implica; Que vontade de saber o anima, já que a vontade de verdade foi descartada; Que tipo de efeito Foucault pretende gerar na ordem prática; Quais são as estratégias utilizadas por ele?

Procuraremos adentrar nesses problemas retomando a questão da crítica. Como vimos acima, para Foucault, a crítica é o nome que genericamente podemos dar à reflexão filosófica que, mais do que a apreensão da verdade, pretende compreender nossa relação com a verdade. A partir do que Foucault falou sobre a atitude filosófica crítica, procuraremos, então, esclarecer alguns pontos sobre seu empreendimento filosófico, já que este também deve ser considerado crítico. Além disso, uma vez que a discussão sobre a crítica nos permitirá compreender como, para Foucault e em Foucault, uma reflexão sobre a linguagem se dá em paralelo com uma reflexão sobre o homem, procuraremos concluir nosso trabalho tendo em vista que essa relação entre homem e linguagem fora o problema inicial lançado pelo presente estudo. 


\section{CONCLUSÃo: A FILOSOFIA CRÍtica de FOUCAULT E A RELAÇÃo ENTRE HOMEM E LINGUAGEM}

A partir do final da década de 70, Foucault discute de modo mais detalhado a questão da crítica em três ocasiões diferentes. A primeira delas consiste numa conferência pronunciada em maio de 1978, na Société Française de Philosophie, local onde 10 anos antes pronunciara outra conferência, esta mais conhecida, intitulada “Qu'est-ce qu'un auteur?”. O título da conferência de 78 é “Qu'est-ce que la critique? [Critique et Aufklärung]” e está publicada no Boulletin de la société française de philosophie de abril e junho de 1990. O segundo comentário importante de Foucault sobre a crítica ocorreu na aula do dia 5 de janeiro de 1983, do curso Le gouvernement de soi et des autres. O último texto sobre o assunto foi publicado em 1984 com o título "What is Enlightenment? [Qu'est-ce que les Lumières?]”, em The Foucault Reader, e está republicado em Ditos e escritos.

Gostaríamos aqui de retomar os pontos mais importantes sobre a concepção foucaultiana de crítica e esclarecer seu próprio empreendimento filosófico como uma atitude crítica. Sendo assim, além dos textos que tratam especificamente da questão da crítica, retomaremos passagens em que o filósofo fala de seu próprio fazer filosófico que mostram que ele deve ser compreendido como crítica. Trata-se, em linhas gerais, de mostrar que Foucault, com sua filosofia crítica, está preocupado em enfrentar certo modo de fazer filosofia que se tornou hegemônico e dominante e propor um espaço possível para pensar de modo diferente.

Segundo Foucault, como vimos, vivemos sempre sob certo regime político da verdade que, em função de diferentes interesses, estabelece como deve ser nossa relação com a verdade: estabelece o que deve ser considerado falso ou verdadeiro numa determinada época, que tipo de objeto devemos conhecer, que tipo de sujeito devemos ser a fim de conhecermos esses objetos, quais conceitos e teorias podemos usar a fim de conhecermos as coisas, os outros e nós mesmos. Diante desse cenário, caberá à crítica foucaultiana colocar em questão a "polícia discursiva" a que estamos submetidos e o regime de verdade dominante em nossa época a fim de nos libertar, dentro dos limites possíveis, de sua sujeição. Nesse sentido, diz Foucault, "a crítica será a arte da inservidão voluntária, aquela da indocilidade refletida" 461 .

Levando em consideração que aquele que voluntariamente não obedece ao outro obedece a si mesmo, dizer que a crítica consiste na arte da inservidão voluntária é a mesma coisa que dizer que ela é a arte da autonomia. Ora, é justamente esse paralelo entre a atitude crítica e a autonomia que Foucault procura estabelecer em todos seus comentários sobre a crítica.

\footnotetext{
${ }^{461}$ Foucault, “Qu'est-ce que la critique?”, p. 39.
} 
Em todos os textos em que Foucault discute o tema da crítica, é Kant que está em questão. Isso não significa, contudo, que a atitude crítica seja privilégio do autor das Críticas. Segundo Foucault, a história da atitude crítica, pelo menos aquela que influencia diretamente Kant, tem origem nas lutas religiosas e espirituais da Idade Média que antecedem a Reforma protestante ${ }^{462}$. Teria sido no âmbito religioso, mais do que em qualquer outro domínio, que certo uso ilegítimo da razão teria levado a um excesso de poder e de dominação e que a falta de legitimidade do conhecimento teria induzido a efeitos de dominação, comprometendo, assim, o uso autônomo dela. Neste contexto, diz Foucault, a atitude crítica de Kant aparecerá como um ensinamento acerca dos limites necessários que a razão precisa respeitar a fim de não induzir nem a um excesso de poder, de autoridade e de dominação, nem a um excesso de passividade, submissão e obediência.

Não nos cabe aqui fazer uma genealogia da atitude crítica, mesmo porque esse foi, de certo modo, o trabalho realizado por Foucault ${ }^{463}$. Interessa aqui retomar alguns elementos dessa atitude que nos ajudam a compreender o trabalho filosófico de nosso autor e de que maneira sua filosofia é a um só tempo uma reflexão sobre o homem e sobre a linguagem.

O mais importante a notar é que a atitude crítica de Kant está ligada a um questionamento sobre o conhecimento e seu uso legítimo. Nesse sentido, a fim de não ser governado ali onde posso exercer minha autonomia, meta do Esclarecimento, é preciso em primeiro lugar conhecer os usos legítimos de nossa razão, ou seja, é preciso em primeiro lugar fazer uma crítica da razão. A crítica, nesse sentido, é condição da autonomia. Por outro lado, a autonomia é o que justifica a crítica.

A cópula crítica/autonomia é analisada por Foucault principalmente a partir da relação entre crítica e Aufklärung, em Kant. O texto central visitado por nosso autor é o famoso opúsculo que Kant escrevera para o jornal Berlinische Monatschrift, em 1784, intitulado "Was ist Aufklärung?".

Esse escrito de Kant deixa claro a importância do trabalho crítico no interior de sua obra e de seu pensamento. Segundo Foucault, o texto sobre o Esclarecimento evidencia que o criticismo kantiano não tem uma finalidade meramente epistemológica. Sua relevância não está somente em ensinar a verdade de nossa razão, mas em ensinar que o conhecimento dos usos legítimos de nossa

\footnotetext{
462 Diz Foucault: "é preciso procurar a origem da história da atitude crítica, no que ela tem de específico no Ocidente, e no Ocidente Moderno a partir dos séculos XV e XVI, nas lutas religiosas e nas atitudes espirituais na segunda metade da Idade Média. No momento em que se coloca o problema: como ser governado, vamos aceitar ser governados dessa maneira? As coisas estão, então, no seu nível mais concreto, o mais historicamente determinado: todas as lutas em torno da pastoral na segunda metade da Idade Média prepararam a Reforma e, creio, foram uma espécie de solo histórico sobre o qual se desenvolveu esta atitude críica" (Foucault, "Qu'est-ce que la critique?", p. 54).

${ }^{463}$ Numa conferência realizada nos Estados Unidos em 1983 sobre a parrhesia grega, citada acima, o filósofo confirma: "aqui vocês vão reconhecer um dos meus objetivos nesse seminário, qual seja, a construção de uma genealogia da atitude crítica na filosofia ocidental. Isso constitui o objetivo geral desse seminário" (Foucault, "Discurso e verdade: seis conferências", p. 112).
} 
razão é condição necessária para nos tornarmos autônomos. Ou seja, o conhecimento proporcionado pela crítica é um conhecimento interessado e não desinteressado: o conhecimento do que podemos saber, fazer e esperar não tem como finalidade o conhecer por conhecer, mas terá utilidade para o alcance da autonomia. O conhecimento de nossa razão tem uma finalidade bem precisa que vai além de um interesse teórico: garantir que não sejamos governados ali onde podemos e devemos seguir nossa própria razão, onde podemos dar a nós mesmos nossas próprias regras, onde, enfim, podemos e devemos ser autônomos. Nesse sentido, conclui Foucault na conferência dos Estados Unidos, "a Crítica é, de alguma maneira, o livro de bordo da razão que se torna maior no Aufklärung, e inversamente, o Aufklärung é a época da crítica"464.

De acordo com Foucault, os três casos estudados por Kant no que diz respeito à minoridade do homem evidenciam a centralidade do empreendimento crítico para o esclarecimento. Confirma nosso autor: "Parece-me que é preciso ler a análise do que é a minoridade em função das três críticas que estão subjacentes e implícitas no texto" ${ }^{465}$. Os três casos, lembremos, referem-se a situações em que o homem, ali onde podia conduzir a si mesmo, deixa-se ser conduzido por outro: deixa seu entendimento ser guiado por um livro, quando podia fazer o uso autônomo de seu próprio entendimento; deixa um diretor de consciência guiar sua consciência moral ali onde podia agir de acordo com as leis da própria razão; deixa sua saúde ser guiada por um médico ao invés de ser o sujeito de seus próprios juízos. Esses três exemplos deixam claro que a situação de minoridade depende da maneira como usamos nossas faculdades, o entendimento, a razão e o juízo. Na situação de minoridade, fazemos um mau uso dessas faculdades, pois fazemos um uso heterônomo e não autônomo delas. É aqui, então, que, segundo Foucault, entram em cena as críticas, uma vez que são elas que ensinam como ter um uso legítimo de nossas faculdades.

Sabemos, pois que as críticas ensinam que o uso legítimo de nossa razão não deve ultrapassar os limites da experiência. Usamos legitimamente nossas faculdades quando reconhecemos os limites do que pode ser conhecido e quando não estendemos a razão para além da experiência. Sabemos também que a saída da minoridade exige coragem, coragem de se fazer uso de seu próprio entendimento, ou seja, de se fazer dele um uso autônomo. Ora, diz Foucault, é fácil mostrar que a coragem de saber implicada no Aufklärung diz respeito ao reconhecimento dos limites do conhecimento ${ }^{466}$.

\footnotetext{
${ }^{464}$ Foucault, "What is Enlightenment?”, in DE II, p. 1386.

${ }^{465}$ Foucault, Le gouvernement de soi et des autres, p. 30.

${ }^{466}$ Cf. Foucault, “Qu'est-ce que la critique?”, p. 41.
} 
Foucault ressalta que o estado de minoridade, para Kant, é de absoluta responsabilidade dos homens; ele não tem a ver nem com uma impotência natural ou com um estado infantil da humanidade, nem com uma situação político e jurídica que por um excesso de poder privaria os indivíduos do exercício legítimo de seus direitos. Não. São os próprios homens, por preguiça e covardia, que escolhem permanecer em estado de minoridade, que escolhem a heteronomia ao invés da autonomia. A partir de uma espécie de ilusão necessária somos levados a acreditar que a submissão é conveniente, que ser guiado e governado por um outro é mais fácil do que guiarmos e governarmos a nós mesmos ${ }^{467}$. É por isso, então, insiste Foucault, que é preciso coragem. É preciso coragem, decisão e força para vencer a covardia e a preguiça e para enfrentarmos a árdua tarefa de realizarmos um bom uso de nós mesmos. Afinal, não podemos fazer qualquer uso de nós mesmos, não podemos nos guiar e nos governar de qualquer maneira. Devemos procurar saber qual o uso legítimo que podemos ter de nós mesmos. Nesse sentido, o uso autônomo de nossas faculdades deve coincidir com seu uso legítimo.

No que diz respeito à legitimidade do conhecimento, o maior ensinamento da crítica é mostrar que o conhecimento legítimo é aquele que respeita certos limites. Essa parece ser, aos olhos de Foucault, a maior utilidade das críticas para o Aufklärung. Afinal, para que o uso autônomo de nossas faculdades seja legítimo, é preciso que o governo de si mesmo se dê sempre no interior de certos limites. É preciso, pois, que se saiba distinguir entre uso público e uso privado da razão; que se saiba que a autonomia e a obediência a si mesmo deve se limitar ao campo em que nos colocamos como sujeitos universais, aquele em que, como seres racionais, nos dirigimos a seres racionais, como, por exemplo, no âmbito em que um escritor se dirige livremente a seus leitores; que se saiba que no âmbito privado, no âmbito em que nos colocamos como sujeitos particulares, sujeitos que fazem parte de um máquina e de um sistema político, administrativo e econômico, enfim, sujeitos que estão submetidos a uma série de regras e normas coletivas, que nesse âmbito é preciso obedecer, não é possível pensar livremente, é preciso ser heterônomo, é preciso que o uso de nossas faculdades não seja livre, mas que dependa do governo e dos interesses do sistema que nos circunda e do qual fazemos parte. Assim, se, por um lado, as críticas ensinam que a legitimidade de nossos conhecimentos implica usar a razão dentro dos limites da experiência, por outro lado, a exigência do esclarecimento é que o uso autônomo de nosso entendimento se dê dentro dos limites do espaço público. Nos dois casos trata-se, portanto, de saber até onde podemos e devemos usar nossa razão. Ou seja, tanto na crítica quanto no Aufklärung encontramos a tese de que o uso da razão deve sempre respeitar certos limites: deve se dar dentro dos limites da

\footnotetext{
${ }^{467}$ Cf. Foucault “Qu'est-ce que la critique?”, pp. 31-2.
} 
experiência, se não quiser cair em ilusões, mas alcançar um conhecimento legítimo; deve se dar dentro dos limites do uso público da razão, se não quiser se submeter ao governo dos outros, mas garantir a autonomia.

É curioso que em todos esses seus comentários sobre a crítica e o Aufklärung Foucault não se refira à Antropologia de um ponto de vista pragmático. O texto que servira de tema para a tese complementar de 1961 e que, a nosso ver, dá as linhas de força para todo o trabalho posterior do filósofo, parece ter sido deixado de lado assim que Foucault termina de escrever seu trabalho. O autor não retomou a tese nem mesmo para fazer os ajustes necessários para uma publicação e em nenhum momento, até onde sabemos, voltou a se referir à antropologia kantiana.

A mesma coisa, no entanto, não podemos falar de sua relação com Kant. Não só em 1966, em As palavras e as coisas, o filósofo alemão tem um papel decisivo principalmente no capítulo IX, "O homem e seus duplos", que trata da situação da filosofia moderna a partir do problema do duplo empírico-transcendental, mas, como acabamos de ver, desde o final da década de 70, Kant está presente no trabalho de Foucault por meio do tema da crítica e do Aufklärung. A questão, então, a se colocar é: por que Foucault nunca mais voltou a falar da antropologia pragmática? Será mesmo que ela é assim tão central para o pensamento de nosso autor, como tentamos mostrar ao longo desse trabalho? Acredito que sim. Do meu ponto de vista, em seu comentário sobre a Antropologia de um ponto de vista pragmático, Foucault dá indícios de quais eram, desde o início, seus interesses filosóficos. Seguramente muita coisa mudou entre 1961, ano da tese complementar, e 1978, ano da conferência sobre a crítica. Certamente Foucault reformulara seu modo de pensar, deixara de lado algumas hipótese e ideias e adotara outras no lugar, insistira em pontos que lhe pareceram mais relevantes em detrimento de outros que mostraram-se mais superficiais. Enfim, é claro que num intervalo de 20 anos o trabalho filosófico de um autor não permanece o mesmo. Entretanto, apesar das mudanças, das transformações e das diferenças, é possível encontrar um fio condutor que marca a continuidade do pensamento de Foucault ao longo desses anos. Fio condutor que, a meu ver, nos dá as linhas gerais do empreendimento filosófico do autor, que delimita de modo geral o lugar de onde ele fala e qual sua intenção. Creio, então, que apesar de Foucault não voltar a falar da antropologia pragmática, é possível encontrarmos vizinhanças entre os comentários do filósofo acerca do texto kantiano de 1798 e os comentários sobre o Aufklärung.

Além disso, vale lembrar que Foucault insiste que o grande mote da antropologia kantiana é ensinar o que podemos e o que devemos fazer de nós mesmos enquanto agentes livres, ensinar o uso que podemos e devemos ter de nossas faculdades mentais, de nossas representações, a fim não só de fazermos o melhor uso delas, mas a fim, principalmente, de mantermos nossas forças vitais. 
Vimos que a importância da antropologia, portanto, não está tanto em nos dar um conhecimento do mundo, mas em nos dar um conhecimento de como podemos usar o mundo a fim de garantirmos a sociabilidade e a fim de ficarmos mais vitalizados. Desse modo, vale notar que o interesse foucaultiana pelo tema do $u s o$, em Kant, não aparece somente no final da década de 70 a partir da distinção entre o uso público e o uso privado da razão, mas é já, conforme vimos, um dos pontos centrais do comentário de Foucault no texto de 1961 sobre a antropologia pragmática.

Ademais, vimos também que Foucault insiste que a Antropologia é uma espécie de repetição da Crítica. Vimos, pois, que o cidadão do mundo não deve fazer um uso indiscrimidado de suas representações, mas deve, antes, saber quais são os limites que devem ser respeitados. Nesse sentido, a crítica, enquanto conhecimento dos limites de nossa razão, é tanto a garantia do esclarecimento quanto da humanidade e da vida dos homens. E se acima retomamos uma passagem em que Foucault afirma que a Crítica é o livro de bordo do Aufklärung, vale lembrar que na tese complementar o filósofo já afirmara que a Crítica é o livro de bordo da antropologia pragmática. Assim, se, por um lado, a crítica é importante para a saída da minoridade, uma vez que ela possibilita saber que o uso autônomo da razão deve se limitar ao seu uso público, por outro, ela é também essencial para o cidadão do mundo, uma vez que possibilita saber que o uso que fazemos de nossas representações deve dar-se dentro dos limites da sociabilidade e da vitalidade.

A meu ver, portanto, é sobretudo a partir da problemática do uso e do limite que podemos encontrar um fio condutor entre o primeiro e os últimos textos sobre Kant. Problemática, aliás, que não está presente somente nos comentários a Kant, mas que consiste mesmo no núcleo do pensamento filosófico de Foucault e que, por esse motivo, também norteiam a apropriação que nosso autor faz de Nietzsche.

Vimos acima que, para Foucault, a atitude crítica designa genericamente certa maneira de investigar a verdade. Investigação que não se preocupa tanto com a apreensão da verdade, mas com o modo interessado de nos relacionarmos com ela. Em oposição ao que o filósofo chama de analítica da verdade, a crítica é aquele tipo de investigação filosófica que, mais do que preocupada em conhecer as condições de possibilidade do conhecimento verdadeiro, se interessa em compreender como podemos usar nossos conhecimentos, verdadeiros ou ilusórios, tendo em vista fins não meramente epistemológicos ou teóricos. Ora, esse parece ser exatamente o papel que a crítica kantiana tem quando pensada ao lado do Aufklärung e da antropologia pragmática, mas também parece ser precisamente o papel da filosofia de Nietzsche enquanto genealogia.

Mas, se é assim, se tanto Kant quanto Nietzsche servem de modelo para uma filosofia crítica que se distancia de uma analítica da verdade ao pensarem como usamos a verdade, por que 
Foucault precisa recorrer aos dois filósofos ao invés de se limitar a um deles? Por que Foucault parece precisar tanto de Nietzsche se já em Kant encontrara um modelo filosófico que lhe parecia interessante? E mais: por que Foucault, depois de toda influência nietzschiana visível principalmente em seus escritos da década de 70 que dão centralidade ao tema do poder, volta a falar de Kant e colocá-lo como paradigma de sua atitude filosófica?

Podemos começar respondendo a essas perguntas lembrando que na conferência de 1978, “Qu'est-ce que la critique?", Foucault afirma que se Kant coloca a questão da crítica em termos de legitimidade do conhecimento, ele, Foucault, colocará a questão em termos de poder ${ }^{468}$. Mas o que exatamente significa isso? Segundo Foucault, a crítica, em Kant, mesmo quando é pensada com a finalidade de garantir a autonomia, a sociabilidade ou a vitalidade, questões práticas que ultrapassam o campo epistemológico, consiste num questionamento teórico sobre o conhecimento. Em última instância, ela sempre significa uma teoria do conhecimento, uma teoria que indica quais objetos podem ser legitimamente conhecidos e quais os usos que o sujeito de conhecimento deve fazer de suas faculdades mentais a fim de obter um conhecimento legítimo. Ou seja, a crítica, em Kant, é sempre um questionamento transcendental que se pergunta pelas condições de possibilidade a priori de qualquer conhecimento possível.

Ora, nada mais estranho à intenção filosófica de Foucault do que uma teoria transcendental do conhecimento ou uma teoria transcendental do sujeito que conhece. Para Foucault, se há um questionamento crítico que se pergunta pelas condições de conhecimento, esse questionamento não é propriamente transcendental; ele não quer encontrar nada que seja a priori, nem que tenha validade universal. A crítica, em Foucault, busca, antes, compreender as condições particulares e singulares que possibilitaram que um conhecimento específico existisse e fosse aceito como verdadeiro numa determinada época. Essas condições, como já vimos, concernem ao que Foucault chama de condições de existência do discurso e dizem respeito à série de práticas ligadas a formações dos objetos a serem conhecidos, dos sujeitos que conhecem, dos conceitos e das opções teóricas. Mas vimos também que interessa a Foucault investigar as condições de aceitabilidade do discurso, as forças e os interesses reais que fizeram com que um discurso fosse tido como verdadeiro. E se, por um lado, as condições de existência de um discurso apontam para as práticas discursivas e não discursivas que constroem sujeitos, objetos, conceitos e teorias, por outro lado, as condições de aceitabilidade referem-se às chamadas práticas concretas de poder que se ordenam em função de uma estratégia, que são aplicadas com mais ou menos força, que visam sempre interesses

${ }^{468}$ Cf. Foucault, “Qu'est-ce que la critique?”, p. 47. 
específicos. É, então, na passagem entre uma reflexão crítica sobre as condições de existência do discurso para um reflexão crítica sobre suas condições de aceitabilidade desse discurso, que Foucault precisa passar de Kant a Nietzsche. A genealogia nietzschiana oferece, pois, o modelo de uma investigação sobre nossa relação com a verdade em termos de poder. É verdade que a arqueologia já guarda certas proximidades com o método genealógico. A busca pelas condições de existência do discurso é também uma pesquisa que busca compreender o conhecimento a partir daquilo que é exterior ao conhecimento, à verdade e ao sujeito. Entretanto, é somente a genealogia, enquanto pesquisa do porquê valorizamos e aceitamos determinados discursos como verdadeiros, que consistirá numa reflexão crítica sobre o discurso ou sobre o conhecimento em termos de poder. O caráter genealógico da arqueologia (o fato de ela se direcionar a um campo empírico e exterior ao conhecimento, à verdade e ao sujeito) chega, como vimos, a inverter a empreitada kantiana: ela busca a síntese e a unidade exatamente ali onde Kant via a multiplicidade, no empírico. A genealogia, no entanto, não se satisfaz com a inversão do modelo kantiano. Para Foucault, não basta suspender o transcendental e revitalizar o empírico. Foi preciso, pois, aprender com Nietzsche como investigar o mundo empírico. De que modo? Estando atento às relações de força e de poder que estão por trás dos conhecimentos tidos como verdadeiros.

É também verdade que, em Kant, a filosofia não se restringe a uma compreensão transcendental das condições de possibilidade do conhecimento verdadeiro, isto é, legítimo. Kant se interessa também, por exemplo, em compreender como de fato, isto é, empiricamente, conhecemos o mundo e como de fato podemos usar nossos conhecimentos a fim de nos tornarmos autônomos em nossas relações interpessoais. Textos como Antropologia de um ponto de vista pragmático e "O que é Esclarecimento?” seriam exemplo disso. Os passeios kantianos pelo campo empírico, contudo, ainda são, aos olhos de Foucault, pouco desbravadores. Nesse sentido, é Nietzsche, mais que Kant, que representa, para nosso autor, o grande explorador dessas terras. Assim, se Foucault afirma que não pretende fazer uma crítica em termos de legitimidade do conhecimento, mas em termos de poder, isso parece significar que nosso autor tem como modelo mais Nietzsche do que Kant. Contudo, que fique claro que isso não é a mesma coisa que dizer que nada da crítica kantiana será aproveitado. Muito pelo contrário. Ao longo de nosso trabalho procuramos indicar pelo menos três elementos da crítica kantiana que interessam a Foucault. No entanto, vale notar que, em função da influência nietzschiana, todos esses elementos vão, aos poucos, sofrendo uma inflexão no interior da obra de Foucault.

Primeiramente, a pergunta pelas condições do saber. Em Kant, as condições do saber se reportam ao campo transcendental do conhecimento verdadeiro, em Foucault, porém, elas dirão 
respeito ao campo empírico das condições de existência e das condições de aceitabilidade do discurso. Isso nos leva ao segundo elemento kantiano retomado por Foucault: o uso. Em Kant, importam, como vimos, os usos que fazemos de nossas representações e nossas faculdades mentais; em Foucault, porém, interessam os usos ligados à construção discursiva, usos que nem sempre são da ordem discursiva, como os usos ou as práticas da ordem institucional, mas que de alguma maneira são determinantes para a formação daquilo que é considerado como conhecimento verdadeiro de uma época. Por fim, ao lado da questão da condição de existência e de aceitabilidade do conhecimento e da pergunta pragmática pelo uso, o último elemento kantiano retomado por Foucault diz respeito ao tema do limite. Tema que, a meu ver, também sofrerá uma inflexão nietzschiana e que justificará o retorno a Kant no final da década de 70.

Seguramente, a questão do limite está nos horizontes de Foucault desde cedo. Toda problemática da década de 60 em torno da transgressão e do dehors inspiradas em Bataille e Blanchot parece evidenciar isso. Confirma Foucault em um debate em 1963: "há alguma coisa que me preocupa atualmente, é o sentido que podemos dar a esta noção tão importante da contestação que encontramos em Bataille e um pouco em Blanchot" ${ }^{\prime 69}$. Tratava-se ali, em linhas gerais, de pensar como era possível ultrapassar os limites da normatividade, seja por meio dos prazeres do corpo e do erotismo, como em Bataille, ou por meio da linguagem, como em Blanchot.

Mas não é somente em suas análises literárias que Foucault comenta o problema da transgressão e do limite. A meu ver, esse tema tem uma importância metodológica central, uma vez que tanto a arqueologia quanto a genealogia podem ser compreendidas como pesquisas sobre os limites. Desse modo, é todo o empreendimento filosófico de Foucault que está envolvido com a questão do limite. E no debate citado acima, de 1963, nosso autor confirma essa ideia. Para Foucault não existe cultura que não coloque a si mesma certos limites, que exclua e interdite certos comportamentos, certos modos de pensar e de ser. Nesse sentido, o que ele mesmo pretendia fazer como filósofo era "a história de um desses limites num momento dado" 470 .

A arqueologia é uma pesquisa sobre os limites na medida em que se pergunta, usando os termos de Daniel Defert, pelos "limites do enunciável"471, por aquilo que pode ser dito, uma vez que está no interior de certa formação discursiva e respeita suas regras. Nesse contexto, se a arqueologia, como vimos, tem a tarefa de diagnosticar, o que ela diagnostica é justamente os limites

\footnotetext{
${ }^{469}$ Foucault, “Débat sur la poésie”, in DE I, p. 423.

${ }^{470}$ Idem, p. 426.

${ }^{471}$ Cf. Defert, op. cit., p. 26.
} 
que, numa determinada época e num determinado lugar, devem ser respeitados para que um enunciado possa ser dito. Por outro lado, a genealogia, que também pretende diagnosticar mais do que fundar, deve indicar, não os limites a serem respeitados, mas os limites que podem ser ultrapassados ${ }^{472}$, não as práticas que se devem necessariamente respeitar a fim de se ter um discurso verdadeiro, mas o espaço concreto de uma liberdade possível. E aqui mais uma inflexão nietzschiana. Afinal, é o método genealógico que, ao passar de uma investigação do que se fala para uma investigação de quem fala, complementa o diagnóstico arqueológico e possibilita uma visão mais prática e não tão teórica do jogo a ser enfrentado a fim de se pensar, agir e ser diferente. A investigação genealógica do sistema de forças e de interesses que estão por trás dos discursos possibilita pensar quais são as motivações que levam os sujeitos a se relacionar de determinada maneira com a verdade, a verdade das coisas, dos outros e de si mesmo. Com outras palavras: é a genealogia, e não arqueologia, que possibilita pensar por quais mecanismos os sujeitos estão ligados à verdade e como podem se desligar dela. Mas o que, afinal, isso tem a ver com uma investigação acerca dos limites ultrapassáveis?

Ora, ao indicar positivamente o "sistema real de dominação" que está por trás de nossa relação com a verdade, a genealogia ensina que estamos inseridos, não só passivamente mas também ativamente, no interior de um jogo onde estão em questão interesses diversos. Ao mostrar o que o pensamento "pensa silenciosamente", a genealogia permite pensar diferentemente ${ }^{473}$. Por um lado, ela ensina que nossa vontade de saber é determinada por todo um sistema de relações que independe de nós; ensina que a vontade individual de cada sujeito está submetida a uma série de relações de poder que estabelecem quais são os discursos que devem ser aceitos como verdadeiros. Por outro lado, ao mostrar que as relações de poder sempre implicam lutas de interesses, a genealogia ensina também que todo sistema de dominação consiste num jogo estratégico que está sempre em aberto, que no seu interior sempre há forças que se contrapõem a ele. A genealogia mostra, portanto, que cabe a cada indivíduo se arriscar nesse jogo ao propor uma estratégia de contestação. Mas, para ultrapassar os limites do aceitável, para enfrentar a vontade de saber de uma época, é preciso coragem. Coragem de se arriscar no interior de uma luta da qual não se sabe quem sairá vitorioso, afinal, assevera Foucault, nunca se sabe se os "esforços feitos a fim de mudar a maneira de ver, modificar o horizonte daquilo que se conhece e para tentar distanciar-se um pouco" levam efetivamente a pensar diferentemente ${ }^{474}$. De qualquer modo, é preciso coragem; coragem

\footnotetext{
472 Cf. Foucault, “What is Enlightenment?”, in DE II, p. 1393.

${ }^{473}$ Cf. Foucault, O uso dos prazeres, p. 14.

${ }^{474}$ Foucault, O uso dos prazeres, p. 15.
} 
para tentar fazer valer suas vontades, desejos e interesses pessoais frente à vontade, ao desejo e ao interesse dominantes, coragem para ao menos tentar explorar o que pode ser mudado e para tentar pensar diferentemente ${ }^{475}$. E se isso nos faz pressentir a vontade de potência nietzschiana, aquela que faz dos espíritos fortes os espíritos livres, vale dizer que essa coragem exigida por Foucault nos faz lembrar também de Kant, visto que a saída da minoridade, como vimos, requer igualmente coragem. É aqui, então, que, a meu ver, os dois filósofos alemães voltam a se encontrar e que Kant volta ao centro da cena.

Assim, se, ao longo da década de 70, Foucault deixa de lado o autor da Antropologia de um ponto de vista pragmático e intensifica suas pesquisas de cunho mais nietzschiano sobre as relações de poder, no final desses anos ele volta a Kant e retoma o tema da coragem e da responsabilidade individual como condição para a autonomia. E se já era possível pensar uma vizinhança entre Kant e Nietzsche a partir do que Foucault escrevera na tese complementar, a vizinhança agora se propõe de outra perspectiva. Vimos que uma primeira aproximação entre os filósofos alemães dava-se ali onde ambos propunham que a utilidade de nossos conhecimentos dependem dos usos que fazemos deles. A antropologia kantiana ensinara, por exemplo, que é legítimo o uso de nossas representações que promovem a sociabilidade e a humanindade, assim como a vitalidade; por outro lado, nas aulas sobre Nietzsche, Foucault insistira que o conhecimento, para esse filósofo, só tem utilidade quando aumenta nossa vontade de potência. A partir do final da década de 70, entretanto, o emparelhamento de Kant e Nietzsche dar-se-á com o tema da autonomia e da coragem.

É verdade que o tema da autonomia já está lá na antropologia kantiana, que trata do que podemos e devemos fazer de nós mesmos como agentes livres, e que é também anunciado pela teoria da vontade de potência nietzschiana cujo princípio de ação está na liberdade que o sujeito tem de agir sobre si mesmo a fim de permanecer vivo. No entanto, não me parece que o interesse em resgatar o tema da autonomia esteja exclusivamente no fato de ele indicar a possibilidade ética do indivíduo agir com liberdade sobre si mesmo. A meu ver, interessa a Foucault a importância política da autonomia. Nesse sentido, a função libertadora que Foucault atribui à crítica não diz respeito somente à liberdade individual daquele que escreve a crítica e que, graças a ela, pode pensar, agir e ser diferente, mas deve também possibilitar que os outros se tornem autônomos, que outras pessoas, por exemplo, possam perceber de maneira diferente a loucura, a delinquência, a sexualidade ${ }^{476}$.

\footnotetext{
${ }^{475}$ Cf. Foucault, O uso dos prazeres, p. 13.

476 Sobre a função libertadora da crítica, Foucault afirma: a máquina crítica "que recoloca em questão certas relações de poder, [...] tem, ou pelo menos deveria ter, função libertadora" (Foucault, A verdade e as formas jurídicas, p. 156).
} 
Pierre Hadot, em uma entrevista intitulada “Qu'est-ce que l'éthique?"477, fala de Foucault como um dandy ${ }^{478}$. Para Hadot, a crítica, em Foucault, não passaria de um exercício espiritual individual; a possibilidade de liberdade que ela indica, só seria útil ao indivíduo corajoso que decidisse, por meio de uma ação heroica, resistir ao status quo e construir-se a si mesmo, com autonomia, como uma obra de arte. É verdade que toda essa temática dandy, e também nietzschiana, de uma estética da existência está presente nos últimos escritos de Foucault. Porém, ela não significa, a meu ver, um individualismo selvagem. Não creio que, para Foucault, a possibilidade da ação livre limita-se ao âmbito do indivíduo, da ética, do domínio em que o indivíduo relaciona consigo mesmo. É verdade que no texto "What is Enlightenment?", de 1983, Foucault fala do dandy de Baudelaire e compara sua atitude crítica tanto com a atitude crítica da Aufklärung quanto com seu próprio ethos filosófico. No entanto, mais do que defender a tese de que a única coisa que resta ao sujeito diante de um mundo normatizado é a liberdade de estilizar sua própria existência, importa mais a Foucault mostrar que para se resistir a um sistema de dominação é preciso passar pela instância mais íntima dos indivíduos, a de seus desejos, interesses e vontades. É preciso pois ter coragem para assumir uma certa atitude, a atitude de modernidade, como ele chama. Atitude que Foucault encontra sim em Baudelaire, mas também, e principalmente, em Kant. Kant é, portanto, ao contrário do que poderia supor Hadot, um dos grandes homens de Foucault.

$\mathrm{Na}$ introdução de $O$ uso dos prazeres, Foucault deixa claro que é da opinião de que a filosofia deveria consistir num exercício intelectual que modifica o ser individual do filósofo:

O "ensaio" - que é necessário entender como experiência modificadora de si no jogo da verdade, e não como apropriação simplificadora de outrem para fins de comunicação - é o corpo vivo da filosofia, se, pelo menos, ela for ainda hoje o que era outrora, ou seja, uma "ascese", um exercício de si, no pensamento ${ }^{479}$.

Com efeito, a pesquisa crítica e histórica de Foucault consiste, como afirma o próprio filósofo, num “exercício de si” que possibilita que ele, individualmente, pense de modo diferente; contudo também é fato que Foucault não quer mudar somente seu próprio modo de pensar, mas pretende colocar em questão todo o esquema que sustenta certo pensamento vigente de uma época ${ }^{480}$. Ou seja, o exercício de si no qual consiste sua filosofia não perde de vista o "todo" dentro do qual está inserida e do qual faz parte. A centralidade da ética e de toda a temática em torno das

\footnotetext{
${ }^{477}$ Entrevista publicada em Exercices spirituels et philosophie antique, de 2002.

478 Diz Hadot: "Foucault centrou sua ideia de práticas de si sobre uma certa atitude do indivíduo, que ele chamou de estética da existência e que consiste em fazer com que sua existência seja bela. Reprovo, então, um pouco em Foucault o que chamei de seu 'dandismo'. Os grandes homens de Foucault são sempre dandys, como Baudelaire - pessoas que procuraram, em primeiro lugar, ter uma existência bela” ( Hadot, “Qu'est-ce que l'éthique?”, p. 390).
}

${ }^{479}$ Foucault, $O$ uso dos prazeres, p. 13.

${ }^{480}$ Cf. Foucault, O uso dos prazeres, p. 10. 
práticas de si e da constituição da subjetividade nos últimos escritos de Foucault não pode ser pensada separadamente do restante de sua obra que indica o sistema discursivo vigente e dominante numa época e as possibilidades de superá-lo.

A meu ver, a estratégia foucaultiana de retomar o tema do Aufklärung tem justamente o intuito de marcar a importância da ética para a política, marcar que a ética não pode ser pensada separadamente da política. Não é por acaso que Foucault inicia seu penúltimo curso, de 1982-1983, intitulado Le gouvernement de soi et des autres, retomando esse tema em Kant. O opúsculo de Kant dedicado à questão mostra precisamente que a mudança política que estava em vias de acontecer no presente de Kant, o Esclarecimento, era de responsabilidade de cada indivíduo; a coragem exigida pelo Aufklärung dependia de uma decisão individual de não ser governado e de dar a si mesmo suas próprias leis. Em Foucault, a relação entre ética e política parece dar-se de modo semelhante, visto que a não obediência ao regime atual de dominação deve ser, além de possível, desejável ${ }^{481}$. Mas aqui vale a pena fazer uma ressalva: não é porque Foucault recorre à ética e à instância individual que ele volta a uma teoria tradicional do sujeito para fundamentar sua teoria do poder. O sujeito, em Foucault, aparece sempre no interior de relações de poder; ele nunca diz respeito a um sujeito puro, universal, transcendental. Ou seja, o sujeito é sempre limitado. E é aqui que o espírito do Aufklärung se faz presente. Para nosso autor, é um excesso considerar o sujeito com uma liberdade absoluta capaz talvez não de mudar o mundo e a vida, mas pelo menos o sentido que lhe dá a eles. Para Foucault nem o sentido que damos às coisas está totalmente em nosso poder. Isso é ilusão e certamente vai muito além de nossos limites! ${ }^{482}$

Assim, quando dizemos que a resistência a um sistema de dominação, de uma formação discursiva determinada, precisa ser desejável, isso não significa fazer apelo a um sujeito puro de liberdade, nem a um sujeito com uma liberdade absoluta ${ }^{483}$. O apelo é a um sujeito singularizado no tempo e no espaço: um sujeito que se vê submetido a certo regime enunciável, regime normativo sustentado por práticas institucionais específicas, que vê diante de si possibilidades limitadas de uma ação livre e que, portanto, sente um desejo de não ser governado pelos outros de determinada maneira e um desejo de governar a si mesmo de modo específico. Ou seja, o recurso à ética, em

\footnotetext{
${ }^{481}$ Cf. Foucault, “What is Enlightenment?”, in DE II, p. 1393.

482 Sobre a ideia de que as considerações humanistas são um excesso e uma ilusão, cf. "Sur l'archéologie des sciences. Réponse au Cercle d'épistémologie", in DE I, p. 754, e "Réponse à une question”, in DE I, p. 723.

483 Vale notar que o sujeito puro de liberdade refer-se ao sujeito transcendental da Crítica da Razão Prática de Kant, enquanto o sujeito de liberdade absoluta refer-se ao sujeito sartriano. Em sua resposta a Sartre, Foucault coloca o autor de Ser e Nada no interior da tradição que acredita que o homem é um sujeito soberano, totalmente senhor de sua consciência, de sua liberdade e de sua existência. Ora, diz Foucault, essa imagem de homem é correlata à imagem de Deus e é por isso que é preciso propor, como fez Nietzsche e talvez Freud, um Übermensch.
} 
Foucault, não diz respeito à afirmação de um sonho vazio de liberdade ${ }^{484}$, mas a um desejo de uma liberdade limitada: um desejo de liberdade que nunca pode ser pensado separadamente do sistema de dominação no interior do qual se está inserido e que só pode ser contestado a partir de onde o ultrapassamento é possível.

Que não estranhemos esse lugar tão situado e limitado do sujeito. Seu papel já estava demarcado desde os escritos da década de 60. Vimos já que em A arqueologia do saber Foucault insistia que o sujeito de enunciação, aquele que realiza o discurso, é sempre um sujeito que se constitui a partir de práticas específicas, a partir de um modo específico de subjetivação; um sujeito que sempre fala de um lugar determinado, olha de um ou outro modo para o objeto ao qual se refere, apreende esse objeto de uma ou outra maneira, utilizando esse ou aquele conceito, essa ou aquela teoria. Foucault defende a mesma tese num artigo publicado em Esprit em 1968:

[...] o que me importa é mostrar que não há de um lado os discursos inertes [...] e depois, de outro lado, um sujeito todo poderoso que os manipula, os transforma, os renova; mas que os sujeitos discursivos fazem parte do campo discursivo - eles têm aí seu lugar (e suas possibilidades de mudar de lugar), sua função (e suas possibilidades de mudar de função). O discurso não é o lugar da irrupção da subjetividade pura; é um espaço de posição e de funcionamentos diferentes para os sujeitos ${ }^{485}$.

Ora, é toda essa delimitação do papel que o sujeito deve ter para conhecer tanto as coisas exteriores a ele como a si mesmo que constitui o cenário dentro do qual esse mesmo sujeito pode agir livremente. Percebe-se, então, que a ação livre sempre se dá no interior de um sistema de dominação que impõe as normas do conhecer, no interior de uma série de relações de poder que sustentam certa formação discursiva. Ou seja, a instância ética da decisão individual de não ser governado é inseperável da instância epistemológica que define as condições para o discurso verdadeiro e da instância política das relações de poder e de interesse que permeiam essas condições. Em Foucault, ética, epistemologia e política não podem, portanto, ser pensadas separadamente. Onde há saber, há poder e há um "si", usando os termos de Foucault"86. Toda produção discursiva, todo conhecimento tido como verdadeiro sempre implica certos interesses e poderes que garantem sua normatividade por meio de práticas institucionais e deve ser ou realizado ou colocado em questão por um sujeito. Não um sujeito universal, sempre idêntico a si mesmo, mas

\footnotetext{
${ }^{484}$ Cf. Foucault, “What is Enlightenment?”, in DE II, p. 1393.

${ }^{485}$ Foucault, "Réponse à une question”, in $D E I$, p. 708.

$486 \mathrm{Na}$ introdução ao segundo volume de História da sexualidade, $O$ uso dos prazeres, Foucault afirma que essa correlação entre saber, poder e si é o que constitui a experiência. Nesse sentido, toda experiência implica campos de conhecimento diversos, conjunto de regras e normas apoiadas por instituições, mas implica também a instância ética da subjetividade, a instância em que o indivíduo dá sentido e valor a sua conduta, dever, prazer, sentimento, sensação, sonho etc. instância, enfim, em que constitui a si mesmo como sujeito (sujeito que conhece, sujeito que age política e moralmente). Sobre sua história da sexualidade, o filósofo, então, afirma: "O projeto era, portanto, o de uma história da sexualidade enquanto experiência - se entendemos por experiência a correlação, numa cultura, entre campos de saber, tipos de normatividades e formas de subjetividade" (Foucault, O uso dos prazeres, p. 10).
} 
um sujeito singular, que em cada momento da história assume uma configuração diferente e que se constitui de modo diferente. E a fim de não confundirmos esse novo sujeito com o sujeito tradicional da história da filosofia, talvez seja melhor utilizarmos outro termo empregado por Foucault principalmente em seus últimos escritos: o termo subjetividade. A nosso ver, o termo subjetividade aponta com mais precisão o sentido que Foucault quer para essa noção de sujeito: um sujeito que não é um, mas cindido, não é soberano, mas dependente, não é origem absoluta, mas função sem cessar modificável ${ }^{487}$.

É verdade que a problematização da subjetividade ou dos modos de subjetivação, isto é, da maneira como os indivíduos se constituem a si mesmos como sujeitos, só será esmiuçada a partir dos textos da década de 80, no contexto da moral sexual. Isso não significa, contudo, insistamos, que a ética estivesse ausente nos textos sobre o saber e sobre as relações de poder. Como já indicamos, esses três eixos são inseparáveis e a temática dos modos de enunciação presente desde os escritos arqueológicos é testemunha disso. E se em seus escritos sobre o discurso Foucault dá pouca atenção para o modo como se constitui o sujeito de conhecimento inserido no interior de um campo de saber específico, é porque privilegia os aspectos formais mais gerais da formação discursiva. Naquele momento não lhe interessava compreender como exatamente, por meio de que práticas, deveria se constituir o sujeito a fim de ser capaz de enunciar um discurso verdadeiro. Interessava-lhe, antes, mostrar a existência de uma correlação entre certo tipo de sujeito de conhecimento, certo tipo de objeto, de conceitos e de teorias. A mesma coisa podemos dizer acerca dos textos relativos às relações de poder. Não cabia a Foucault naquele momento discutir como precisamente os sujeitos constituíam-se a si mesmos no interior do campo discursivo sobre a deliquência, por exemplo; mais do que investigar as práticas por meio das quais os indivíduos constituíam-se como sujeitos, sujeitos dominadores ou sujeitos sujeitados, Foucault descreve as práticas institucionais e as estratégias de poder que sustentavam tais discursos. Importava mostrar que todo saber de uma época, que aquilo que é tido como verdadeiro numa época, é sustentado por relações de poder, por interesses e por jogos estratégicos.

Dito isso, retomemos, a fim de concluir, a grande questão que serviu de norte ao presente trabalho, a de que Foucault propõe uma reflexão filosófica que, a um só tempo, pensa o homem e a linguagem.

Vimos que diante da prática filosófica de sua época, Foucault percebe que ou bem ela pensa o homem em termos de uma analítica da finitude que tende a cair na aporia do duplo

\footnotetext{
${ }^{487}$ Cf. Foucault, “La naissance du monde”, in DE I, p. 817.
} 
empírico-transcendental, ou bem ela tende a colocar de lado a questão do homem, da existência e do sujeito, para pensar a linguagem na pureza de suas relações lógicas. De um lado a fenomenologia, de outro a filosofia analítica e o estruturalismo. Nossa hipótese era a de que, frente a essas duas opções, Foucault proporia uma terceira via que procuraria conciliar os dois tipos de reflexão livrando-se dos prejuízos de cada uma delas, isto é, sem excluir o homem, mas também sem cair no problema da circularidade daquilo que determina o homem e daquilo que é determinado por ele.

Ora, no interior desse campo de batalha, de lutas de interesses e de forças, o da filosofia, Foucault se valeu de uma estratégia para combater tanto a fenomenologia quanto o estruturalismo, os dois adversários mais próximo dele. A estratégia começa por uma investigação da linguagem, não do ser ou da essência da linguagem, mas dos seus usos e das práticas ligadas ao dizer (práticas de subjetivação e práticas de objetivação). Depois disso, fazendo um uso estratégico de Nietzsche, Foucault direciona sua investigação para compreender a instância de interesses que está por trás desses usos da linguagem; busca compreender de que modo aquilo que é mais íntimo nos homens, sua vontade, seus desejos, sua existência, participa das práticas discursivas que constroem sujeitos e objetos, ou seja, como o poder se relaciona com saber. Por fim, o último lance de nosso autor consistirá em mostrar que aquilo mesmo que está em jogo no interior de uma formação discursiva que diz a verdade, isto é, o sujeito, nós, os homens, com nossa existência, nossa vontade e nossos desejos, é condição para que ela seja tanto construída como transformada. E se Lebrun assegurava que em Kant ainda era possível nomear Deus desde que não se esquecesse de que ele estava ausente, podemos dizer que, em Foucault, ainda é possível falar em homem, desde que seja sem pretensões fundantes ${ }^{488}$.

${ }^{488}$ Lebrun, Kant e o fim da metafísica, p. 283. 


\section{BIBLIOGRAFIA}

\section{A. Textos de Foucault}

FOUCAULT, Michel. “Qu'est-ce que la critique?", in Boulletin de la société française de philosophie, t. LXXXIV, 1990.

. "Verdade e subjetividade", in Revista de Comunicação e Linguagens, $\mathrm{n}^{\circ}$

19. Lisboa: Cosmos, 1993.

. Dits et écrits, vol. I e II. Paris: Gallimard, 2001.

. A ordem do discurso. Tradução de Laura Fraga de Almeida Sampaio. São

Paulo: Edições Loyola, 2002.

. As palavras e as coisas. Tradução de Salmma Tannus Muchail. São Paulo: Martins Fontes, 2002. (Les mots et les choses. Paris: Gallimard, 2001).

. A verdade e as formas jurídicas. São Paulo: Graal, 2003.

. Microfísica do Poder. Organização de Roberto Machado. São Paulo:

Graal, 2003.

O uso dos prazeres. São Paulo: Graal, 2003.

. A Arqueologia do saber. Rio de Janeiro: Forense Universitária, 2007.

(L’archéologie du savoir. Paris: Gallimard, 2010).

. Le gouvernement de soi et des autres. Paris: Gallimard, 2008.

. "Introduction à l'Anthropologie", in Kant, E. Anthropologie d'un point

de vue pragmatique. Paris: Vrin, 2008. (Gênese e estrutura da Antropologia de Kant. Tradução de Márcio Alves da Fonseca e Salma Tannus Mucchail. São Paulo: Loyola, 2011).

. Leçons sur la volonté de savoir. Paris: Gallimard, 2011.

. "Discurso e verdade: seis conferências", Tradução de Aldo Dinucci,

Alfredo Julien, Rodrigo Brito e Valter Duarte, in Revista Prometeus, Ano 6, No 13, Universidade Federal de Sergipe, 2013.

\section{B. Textos sobre Foucault}

CANGUILHEM, Georges. "Mort de l'homme ou épuisement du Cogito?", In Les mots et les choses de Michel Foucault - Regards critiques 1966 - 1968. Caen: Press universitaires de Caen, 2009. 
CASSOU-NOGUÈS, P. e GILLOT, P. (éd). Le concept, le sujet et la science. Cavaillès, Canguilhem, Foucault. Paris: Vrin, 2009.

CASTRO, Edgardo. Pensar a Foucault: Interrogantes filosóficos de La arqueología del saber. Buenos Aires: Biblos, 1995.

D'ALLONES, Oliver Revault. "Michel Foucault: les mots contre les choses", in Les mots et les choses de Michel Foucault - Regards critiques 1966 - 1968. Caen: Press universitaires de Caen, 2009.

DEFERT, Daniel. "Situation du cours", in Michel Foucault, Leçons sur la volonté de savoir. Paris: Gallimard, 2011.

DELEUZE, Gilles. Foucault. Tradução de Cláudia Sant'Anna Martins. São Paulo: Brasiliense, 2005. . "L'homme, une existence douteuse", in Les mots et les choses de Michel

Foucault - Regards critiques 1966 - 1968. Caen: Press universitaires de Caen, 2009.

ERIBON, Didier. Michel Foucault. Tradução de Hildegard Feist. São Paulo: Companhia das Letras, 1990.

FIMIANI, Mariapaola. Erotica e retorica. Foucault e la lotta per il riconoscimento. Verona: Ombre corte, 2007.

Foucault et Kant, Critique, Clinique, Éthique. Paris: L'Harmattan, 1998.

FORTIER, Frances. Les stratégies textuelles de Michel Foucault: un enjeu de véridiction. Québec: Nuit Blanc Éditeur, 1997.

GARAUDY, Roger. "Structuralisme et mort de l'homme", in Les mots et les choses de Michel Foucault - Regards critiques 1966 - 1968. Caen: Press universitaires de Caen, 2009.

GARO, Isabelle. Foucault, Deleuze, Althusser et Marx. Paris: Alexandra Delabie, 2011.

GROS, Frédéric (org.). Foucault. Le courage de la vérité. Paris: PUF, 2002.

GROS, Frédéric e LÉVY, Carlos (orgs.). Foucault et la philosophie antique. Paris: Éditions Kimé, 2003.

GROS, Frédéric e DAVIDSON, Arnold (orgs.). Foucault, Wittgenstein: de possibles rencontres. Paris: Éditions Kimé, 2011.

HABERMAS, Jürgen. O discurso filosófico da modernidade. Tradução de Luiz Sérgio Repa e Rodnei Nascimento. São Paulo: Martins Fontes, 2002.

HADOT, Pierre. “Qu'est-ce que l'éthique?”, in Exercices spirituels et philosophie antique. Paris: Éditions Albin Michel, 2002.

HAN, Beatrice. L’ontologie manquée de Michel Foucault. Grenoble:Millon, 1998. 
. "Analytique de la finitude et histoire de la subjectivité", in FOUCAULT au

Collège de France: un itinéraire. Pessac: Press Universitaires de Bordeaux, 2003.

. "Introduction à l'Anthropologie", in http://ndpr.nd.edu/review.cfm?id=15505,

consultado em 01/04/2011.

LE BLANC, Guillaume. L'esprit des sciences humaines. Paris: Vrin, 2005.

L'Herne Foucault. Paris: Éditions de L'Herne, 2011.

LEBRUN, Gérard. "Transgredir a finitude”, in Renato Janine Ribeiro (org.), Recordar Foucault. São Paulo: Brasiliense, 1985.

. "Note sur la phénoménologie dans Les mots et le choses", in Michel Foucault

Philosophe. Paris: Seuil, 1989.

LECOURT, Dominique. "Sur l'archéologie et le savoir (A propos de Michel Foucault)", in Pour une critique de l'épistémologie (Bachelard, Canguilhem, Foucault). Paris: François Maspero, 1972.

LUMIÈRES, $n^{\circ} 16$. Foucault lecteur de Kant: le champ antrhopologique. Pessac: Presses Universitaires de Bordeaux, 2010.

MACHADO, Roberto. Ciência e Saber: a trajetória da Arqueologia de Foucault. Rio de Janeiro: Graal, 1982.

MACHEREY, Pierre. De Canguilhem à Foucault: la force des normes. Paris: La fabrique, 2009.

MAGALHÃES, Ruy. "Foucault e Habermas: a propósito de uma crítica filosófica", in Revista de comunicação e linguagens, $\mathbf{n}^{\circ}$ 19. Lisboa: Cosmos, 1993.

MARGOLIN, Jean-Claude. "L'homme de Michel Foucault", in Les mots et les choses de Michel

Foucault - Regards critiques 1966 - 1968. Caen: Press universitaires de Caen, 2009.

MICHON, Pascal e all. Foucault dans tous ses éclats. Paris: L’Harmattan, 2005.

NALLI, Marcos. Foucault e a fenomenologia. São Paulo: Edições Loyola, 2006.

POTTE-BONNEVILLE, Mathieu. Foucault. Paris: Ellipses, 2010.

REVEL, Judith. Foucault, une pensée du discontinu. Paris: Mille et une nuits, 2010.

SABOT, Philippe. Lire Les mots et les choses de Michel Foucault. Paris: PUF, 2006.

SARDINHA, Diogo. Ordre et Temp dans la Philosophie de Foucault. Paris: L'Harmattan, 2011.

SARTRE, Jean Paul. “Jean-Paul Sartre répond”, in L'Arc, n 30. Paris: Duponchelle, 1966.

VEYNE, Paul. Foucault. Sa pensée, sa personne. Paris: Albin Michel, 2008.

. "Un archéologue sceptique", in Dedie Eribon (org.), L'infréquentable Michel

Foucault. Renouveaux de la pensée critique. Paris: EPEL, 2001. 
ZOUNGRANA, Jean. Michel Foucault: un parcours croisé, Lévi-Strauss, Heidegger. Paris:

L'Hermattan, 1998.

WOLFF, "Foucault, l'Ordre du Discours et la Vérité”, in Edgar da R. Marques et al. (orgs.), Verdade, Conhecimento e Ação. São Paulo: Loyola, 1999.

\section{Demais textos}

ARISTÓTELES. Metafísica. Tradução de Leonel Vallandro. Porto Alegre: Editora Globo, 1969. . Ética a Nicômaco. Tradução de Leonel Vallandro e Gerd Bornheim. São Paulo: Nova Cultural, Col. Os pensadores, 1991.

ESPINOSA, Baruch de. Tratado político. Tradução de Manuel de Castro. São Paulo: Abril Cultural, Coleção Os pensadores, 1973.

DETIENNE, Marcel. Les Maîtres de Vérité dans la Grèce archaïque. Paris: Le livre de poche, 2006.

DOSSE, François. História do estruturalismo I e II. Tradução de Álvaro Cabral. Bauru: EDUSC, 2007.

DUCROT, Oswald et al. Qu'est-ce que le structuralisme? Paris: Seuil, 1968.

GIACOIA JUNIOR, Oswaldo. Nietzsche $x$ Kant: uma disputa permanente a respeito da liberdade, autonomia e dever. São Paulo: Casa do saber, 2012.

HEGEL, Georg Wilhelm Friedrich. Fenomenologia do Espírito. Tradução de Paulo Meneses. Rio de Janeiro: Ed. Vozes, 2007.

HEIDEGGER, Martin. Nietzsche. Tradução de Pierre Klossowski. Paris: Gallimard, 1971.

HOFFE, Otfried. Immanuel Kant. Tradução de Christian Viktor Hamm e Valerio Rohden. São Paulo: Martins Fontes, 2005.

HUSSERL, Edmund. L’origine de la géométrie. Tradução de Jacques Derrida. Paris: PUF, 2004.

HYPPOLITE. Jean. Gênese e Estrutura da Fenomenologia do Espírito de Hegel. Tradução de Andrei José Vaczi, Denílson Soares Cordeito, Gilberto Tedéia, Luis Sérgio Repa, Rodnei Antônio do Nacimento. São Paulo: Discurso Editorial, 1999.

. Lógique et existence. Paris: PUF, 1961.

KANT, Immanuel. Crítica da Razão Pura. Tradução de Manuela Pinto dos Santos e Alexandre Fradique Morujão. Lisboa: Fundação Calouste Gulbenkian, 2001.

Antropologia de um ponto de vista pragmático. Tradução de Clélia Aparecida Martins. São Paulo: Iluminuras, 2006. 
LEBRUN, Gérad. Kant e o fim da metafísica. Tradução de Carlos Alberto Ribeiro de Moura. São Paulo: Martins Fontes, 2002.

Les enjeux philosophique des années 50. Paris: Centre George Pompidou, 1989.

LÉVI-STRAUSS, Claude. O pensamento selvagem. Tradução de Tânia Pellegrini. São Paulo: Papirus, 2008.

MANIGLIER, Patrice (org.). Le moment philosophique des années 1960 en France. Paris: PUF, 2011.

MARTON, Scarlett. "Voltas e reviravoltas. Acerca da recepção de Nietzsche na França", in Scarlett Marton (org.), Nietzsche, um “francês” entre franceses. São Paulo: Editora Barcarolla e Discurso Editorial, 2009.

MOURA, Carlos Alberto Ribeiro de. Nietzsche: civilização e cultura. São Paulo: Martins Fontes, 2005.

NIETZSCHE, Friedrich. O nascimento da tragédia ou Helenismo e Pessimismo. Tradução de J. Guinsburg. São Paulo: Companhia das Letras, 1998.

. A gaia ciência. Tradução de Paulo César de Souza. São Paulo: Companhia das Letras, 2001.

. Além do bem e do mal: prelúdio a uma filosofia do futuro. Tradução de Paulo César de Souza. São Paulo: Companhia das Letras 2005.

. Genealogia da moral. Tradução de Paulo César de Souza. São Paulo:

Companhia das Letras, 2006.

. Sobre verdade e mentira. Tradução de Fernando de Moraes Barros. São

Paulo: Hedra, 2010.

. "II Considerações Intempestivas sobre a utilidade e os inconvenientes da

História para a vida", in Escritos sobre História. Tradução Noéli Correia de Melo Sobrinho. Rio de Janeiro: Ed. PUC-Rio; São Paulo: Loyola, 2011.

VUILLEMIN, Jules. L'héritage kantien et la révolution copernicienne: Fichte, Cohen, Heidegger. Paris: PUF, 1954.

WAHL, Jean. Introduction à la pensée de Heidegger. Paris: Le livre de poche, 1998. 